\title{
THE ROLE OF ISLAM IN INDONESIA'S CONTEMPORARY FOREIGN POLICY
}

\author{
Mohamad Zakaria Al-Anshori
}

A Thesis Submitted to the Victoria University of Wellington in Fulfilment of the Requirement for the Degree of Doctor of Philosophy in Political Science and International Relations

Victoria University of Wellington

2016 


\begin{abstract}
This study aims to investigate the extent to which Islam influences Indonesian foreign policy in the post-Suharto era. Specifically, this research intends to examine under what circumstances the influence of Islam on Indonesian foreign policy will be substantial and under what conditions it will have less of an effect. Focusing on the era of the administration of President Yudhoyono, the issues covered in this study embrace Indonesia's policies towards Iran's nuclear programme, Kosovo's independence and Palestinian statehood.
\end{abstract}

This study puts emphasis on the interplay between Muslim groups and the government in relation to the conduct of the country's foreign policy. As interest groups, Muslim groups in Indonesia have had significant concerns about Muslim issues in both Indonesia's domestic affairs and in its foreign policy.

In general, this study argues that there has been an increased role for Islam in Indonesia's post-Suharto foreign policy. Islamic elements and Muslim groups' aspirations have been increasingly included and accommodated in the country's foreign policy. These accommodations are made to the extent that the aspirations these views reflect do not contradict fundamentally with Pancasila as state philosophy, the 1945 constitution and the country's vital national interests, mainly those related to territorial integrity.

Specifically, the case of the Iranian nuclear programme has showed that the government 'bowed' to the Muslim groups' pressures which were backed by the parliament. The government changed its position from supporting UNSC resolution 1747 on sanctions against Iran to abstaining on the similar resolution no. 1803. In this regard, the influence of Muslim groups on the country's foreign policy was important and substantial as Muslim groups' interests and members of parliament's interests did converge against the government's policy on that matter.

The Kosovo case has demonstrated an opposite effect. The government apparently firmed up its non-recognition of Kosovo's independence and disregarded Muslim groups' aspirations. Muslim groups' aspiration to recognise Kosovo's independence is 
perceived to contradict the most vital of the country's national interest, namely national integrity. Finally, the case of Palestinian statehood has showed that the Indonesian government's policy and Muslim groups' aspirations have been aligned (unlike their differences over Iran) with a similar voice being presented. 


\section{ACKNOWLEDGEMENT}

Many people have lent their incredible help and assistance in many different ways throughout my $\mathrm{PhD}$ journey. I have been privileged to have Professor Robert Ayson as my primary supervisor. I benefited greatly from his expertise, clear guidance and supervision, analytical thinking and sharpness, meticulous, careful and critical reading, and constructive, detailed and deep comments which were very beneficial in constructing and sharpening my thesis. He has always showed endless patience and encouragement, excellent support and invaluable advice throughout writing this thesis. I do not think that words are sufficient in expressing my great gratitude and appreciation to him. Without his continued guidance and invaluable help, the completion of this thesis would have been impossible.

I am also greatly indebted to my secondary supervisor, Associate Professor David Capie, for his invaluable guidance and supervision, encouragement and expertise as well as critical comments of my drafts which enabled me to complete this thesis. I am very fortunate to have such a solid and strong supervisory team for my thesis. It has been a delight to have had this relationship with two superb professors, which I believe is a wonderful part of my destiny in life.

My study would also have been impossible without support from my institution, the Indonesian Ministry of Foreign Affairs. I should also take this opportunity to convey my sincere appreciation to Ambassador Agus Sriyono and Ambassador Jose Tavarez, Pak Fery and Bu Ella, Pak Wanton and Bu Shinta, Mas Ali and Mbak Fina, Mbak Muniroh, Pak Budi and Bu Wiwin, Pak Agam and Bu Dewi, all other staff, and the large family of the Indonesian Embassy in Wellington. I would like to convey my greatest gratitude to the Ministry of Foreign Affairs and Trade in New Zealand for granting me the New Zealand ASEAN Scholars Award, which enabled me to study at Victoria University of Wellington for more than three and a half years. I am particularly grateful to Dr Helena Cook, NZAID Scholarship Coordinator at Victoria International. I would also like to thank the Student Learning team at VUW, especially Madeleine Collinge and Karren Commons; and Rebecca McKeown for their valuable assistance with my English language improvement. 
I received assistance and help during my six-month field research in Indonesia. I would like to thank the participants of my in-depth interviews and all my connections and contacts at the MAPK (Senior High School) in Jember, Muslim Student Association (HMI), Piramida Circle Study Club, NU, Muhammadiyah, and Indonesian Ministry of Foreign Affairs which made my field research easy to do. Though I interviewed a number of people, Iwould like to mention a few of them particular, namely Jusuf Kalla, Indonesian Vice President (2004-2009) and (2014-2019), N. Hassan Wirajuda, Indonesian Foreign Minister (2002-2004) and (2004-2009), K.H. Said Agil Siraj (NU's chairman), K.H. Hasyim Muzadi (NU's former chairman), Abdul Mu'ti (Muhammadiyah), Rizal Sukma (CSIS), Dwi Fortuna Anwar (LIPI), Azyumardy Azra (State Islamic University -UIN) Jakarta), as well as the politicians and members of parliament from PKS, PKB, PPP, PAN and Golkar, and journalists.

I have no idea how to express my feelings to my family. My wife, Uli Artati and my daughter, Salma Safira Ainun Naima are always my sources of strength and spirit for my life. My deepest thanks and gratitude are devoted to my father, Drs. HM. Syuhada, mother Hj. Siti Nafsiyah, and to my parents-in-law. 


\section{TABLE OF CONTENTS}

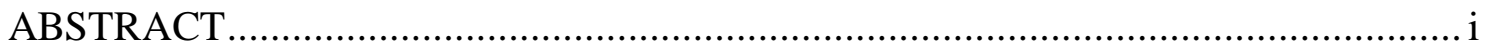

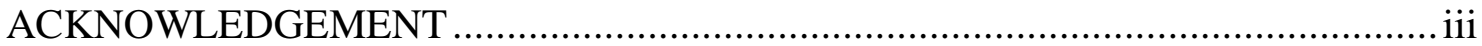

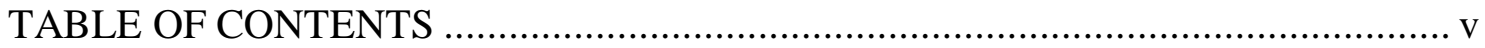

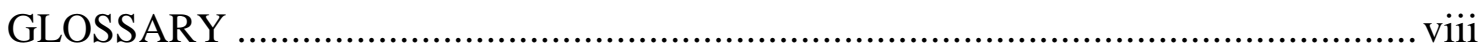

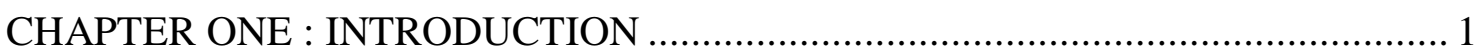

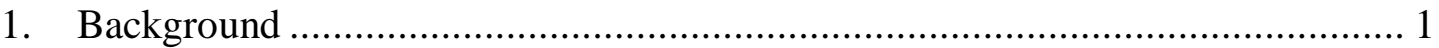

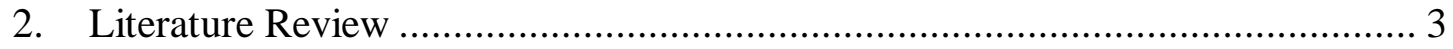

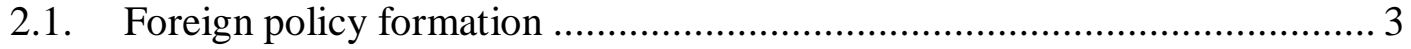

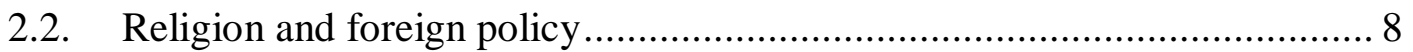

2.3. Islam and foreign policy of Muslim states.............................................. 12

2.4. Islam in Indonesia's foreign policy ........................................................ 19

3. Research methodology ............................................................................. 23

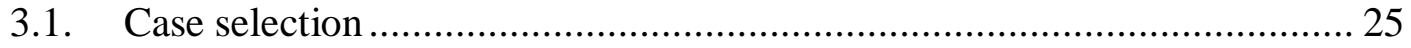

3.2. Data collection and analysis .................................................................... 26

3.2.2. Primary and secondary written documents .............................................. 27

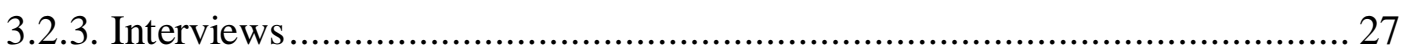

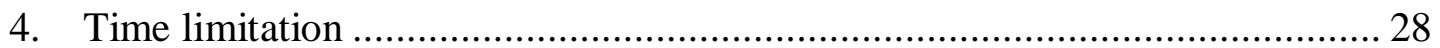

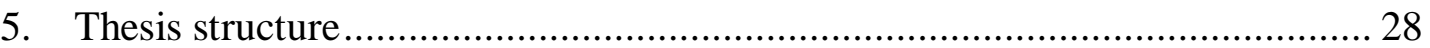

CHAPTER TWO : ISLAM AND INDONESIAN DOMESTIC POLITICS ………….. 31

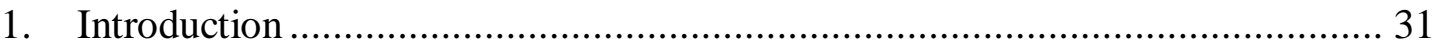

2. The Dutch policy on Islam and the emergence of a Muslim nationalist

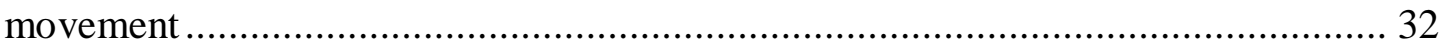

3. The power struggle between secular nationalists and Muslim nationalists ......... 36

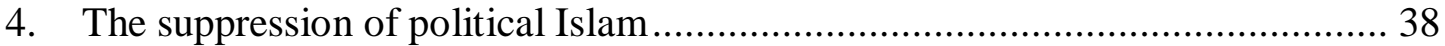

5. The Cultural Islam and Muslims' political rapprochement with Suharto ……... 43

6. Islam and politics in Indonesia's democratic era: Pre-Yudhoyono era ............... 49

7. Islam and politics in Indonesia's democratic era: TheYudhoyono era................ 52

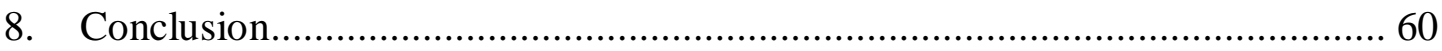

CHAPTER THREE : THE ROLE OF ISLAM IN INDONESIA'S POST-SUHARTO FOREIGN POLICY

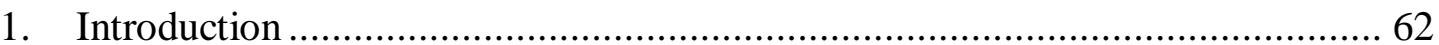

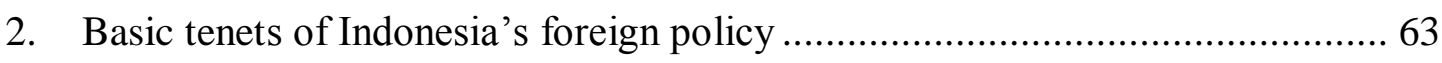




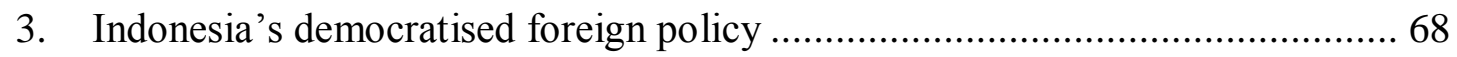

4. Muslim aspirations and the government's response .................................... 74

4.1. The change in Islam's role ................................................................ 74

4.2. Domestic reaction and governmental response to the $9 / 11$ tragedy and the

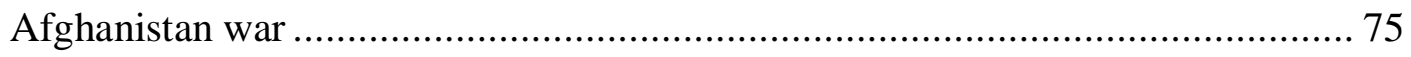

4.3. Domestic reaction to the Iraq war and the government's response............ 81

4.4. Reaction of Indonesian Muslims to the Danish caricatures ...................... 83

5. Toward a new Indonesian international identity .......................................... 86

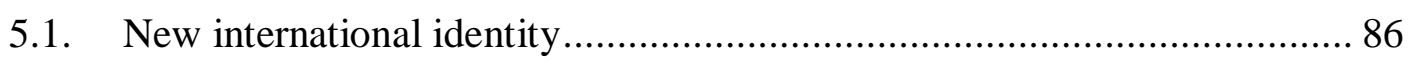

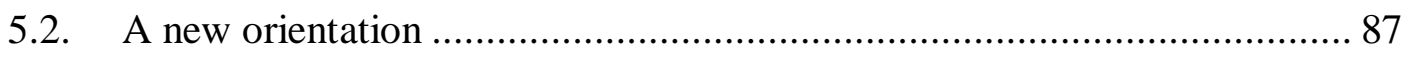

5.3. New activism in Indonesia's foreign policy........................................ 90

5.4. The limits of Indonesia's international identity projection ........................ 95

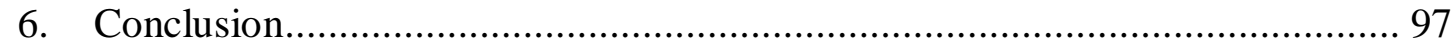

CHAPTER : INDONESIA'S POLICY ON THE IRANIAN NUCLEAR

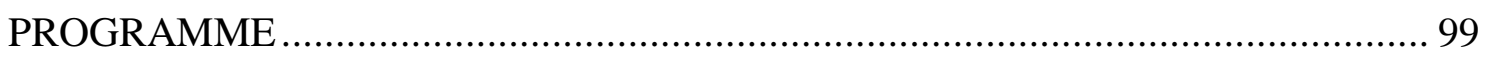

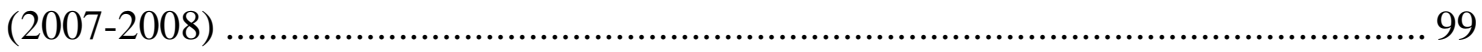

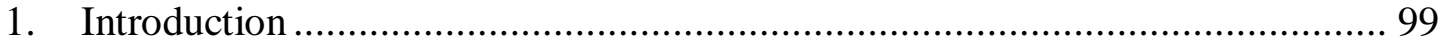

2. The development of the Iranian nuclear programme....................................100

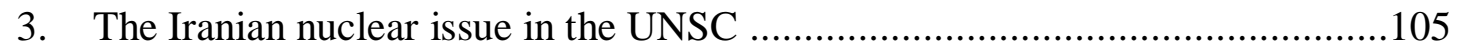

4. Indonesia and the UNSC on Iran's nuclear programme ................................109

5. Indonesia's support for the sanctions on Iran and the domestic response .........113

6. Collaboration between Muslim groups and parliament .................................120

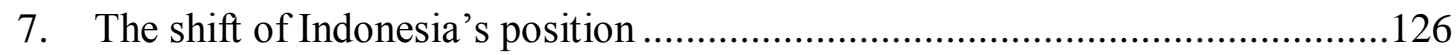

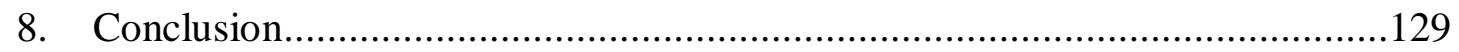

CHAPTER FIVE : INDONESIA'S POLICY TOWARDS KOSOVO'S

INDEPENDENCE: PREEMINENT NATIONAL INTEREST ............................ 131

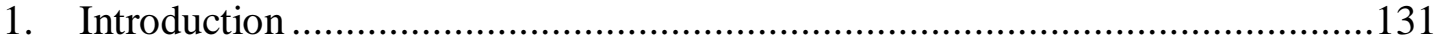

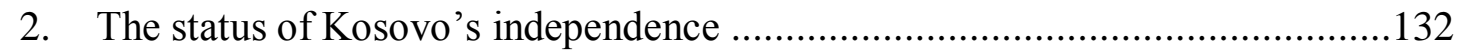

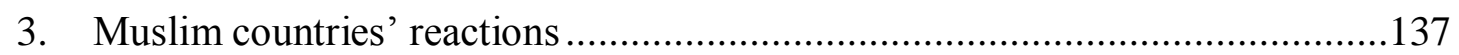

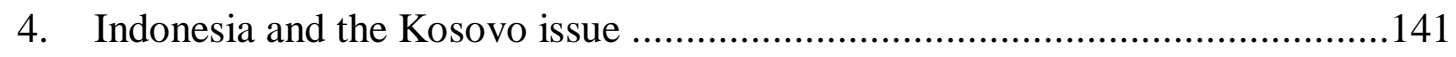

5. Indonesia's middle-ground position on Kosovo's independence......................145

6. Debating Indonesia's position: The government vis-à-vis Muslim groups .......149

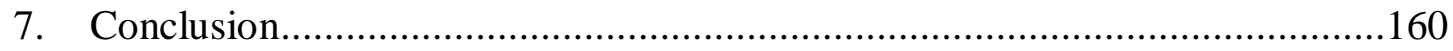




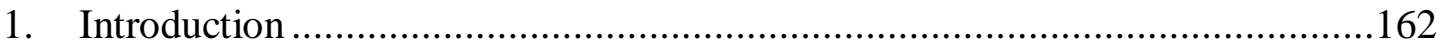

2. A brief overview of the Palestine-Israel conflict.............................................163

3. The roots of Indonesian Muslim's sentiments towards Palestine and Middle

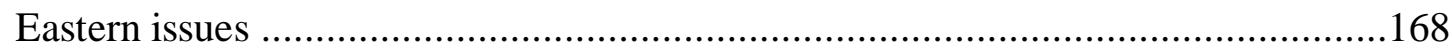

4. Indonesia's policy on the Palestinian question: Historical basis......................171

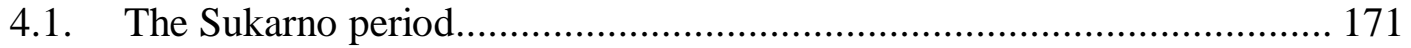

4.2. The Suharto period …........................................................................... 174

5. Indonesia's persistent non-recognition policy towards Israel in the post Suharto

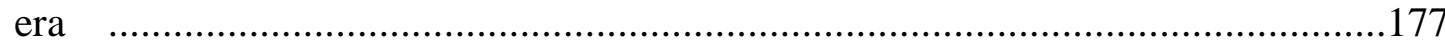

5.1. Abdurrahman Wahid's adventurous proposal....................................... 177

5.2. The Yudhoyono period .................................................................. 182

6. Palestinian statehood and Indonesia's support..............................................189

7. The Gaza wars: Muslim groups' reaction and the government's response .......194

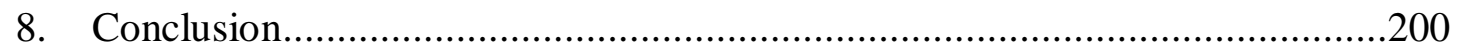

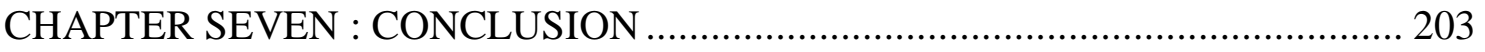

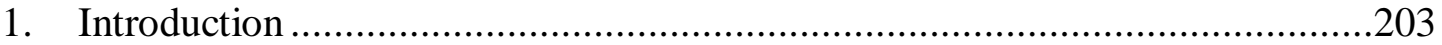

2. The gradual shift in the features of the relationship between the state and Islam

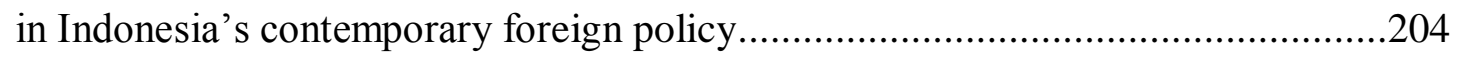

3. Main features of the three case studies .......................................................208

3.1. The Iranian nuclear programme (Chapter Four) ................................. 208

3.2. The recognition of Kosovo's independence (Chapter Five) .................... 209

3.3. Palestinian statehood case (Chapter Six) ............................................. 209

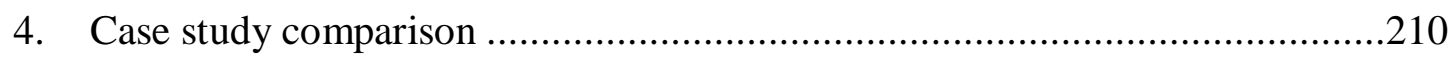

4.1. Muslim groups' aspirations and the government's accommodation.......216

5. Reflection on thesis contribution and future research .................................221

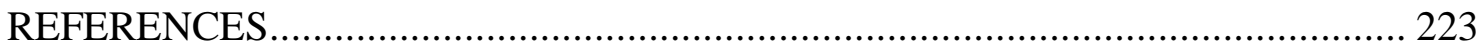

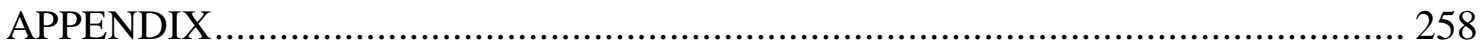




\section{GLOSSARY}

AKP

DI

DDII

DPD

DPR

FPI

Golkar

Guided Democracy

HAMAS

HMI

HTI

IAEA

ICMI

KAMMI

$\mathrm{KH}$.

KISDI

: Adalet ve Kalkınma Partisi (Justice and Development Party), founded in 2001

: Darul Islam (a pro-Islamic-state rebel)

: Dewan Dakwah Islam Indonesia (Islamic

Education Council of Indonesia), founded in 1967

: Dewan Perwakilan Daerah (Regional

Representative Council); the upper house of parliament

: Dewan Perwakilan Rakyat (House of Representatives); the lower house of parliament

: Front Pembela Islam (Islamic Defender Front)

: Golongan Karya (Functional Groups), the state political party under the New Order, and one of the major political parties in the post-Suharto era.

: The Soekarno regime, 1959-66

: Harakat al-Muqāwamah al-' Islāmiyyah (Islamic Resistance Movement), founded in 1988

: Himpunan Mahasiswa Indonesia (Muslim Students Association); founded in 1947

: Hizbut Tahrir Indonesia

: International Atomic Energy Agency

: Ikatan Cendekiawan Muslim Indonesia (Association of Indonesian Muslim Intellectual); founded in 1990

: Kesatuan Aksi Mahasiswa Muslim Indonesian (Unity of Action of Indonesian Muslim Student), founded in 1998

: Kyai Haji (a much respected Islamic cleric who already performed Haji-annual pilgrimage to Mecca).

: Komite Indonesia untuk Solidaritas Dunia Islam (Indonesian Committee for world Islamic 
Solidarity); formed in 1986 to promote the cause of overseas Muslims in conflict zones

KISPA

MFA

MMI

Muhammadiyah

MUI

MPR

NAM

NATO

$\mathrm{NU}$

OIC

PAN

Pancasila

PBB

PBR

PD

PBNU

PDIP
: Komite Indonesia untuk Solidaritas Palestina

(Indonesian Committee for Palestinian Solidarity)

: Ministry of Foreign Affairs

: Majelis Mujahidin Indonesia (Indonesian Islamic Worrior Council)

: Indonesia's largest modernist Islamic organisation, founded in 1912

: Majelis Ulama Indonesia (Indonesian Council of Ulama), founded in1975

: Majelis Permusyawaratan Rakyat (People's Consultative Assymbly)

: Non Aligned Movement

: The North Atlantic Treaty Organisation

: Nahdlatul Ulama (Awakening of Muslim Scholars); Indonesia's largest Muslim organisation, founded in 1926

: Organisation of Islamic Cooperation

: Partai Amanat Nasional (National Mandate Party)

: The five guiding principles of the Indonesian state (belief in God, humanitarianism, nationalism, democracy and social justice

: Partai Bulan Bintang (Crescent Star party), an Islamic modernist political party

: Partai Bintang Reformasi (Star Reformist Party), a splinter of PPP

: Partai Demokrat (Democratic Party), the party led by Susilo Bambang Yudhoyono

: Pengurus Besar Nahdlatul Ulama (Executive Board of NU)

: Partai Demokrasi Indonesia Perjuangan (Indonesian Democratic Party of Struggle), the 
party led by former president Megawati

Sukarnoputri

PK

PKB

PKI

PKS

PLO

PNI

Poros Tengah

PPP

Priyayi

Reformasi

Santri

Santrinisasi

Sarekat Islam

Sharia

Shi'a, Shi'ism

Sunni

Syafi'i

UNGA

UNSC
: Partai Keadilan (Justice Party); formed in 1998 and renamed Partai Keadilan Sejahtera (PKS) in 2003

: Partai Kebangkita Bangsa (National Awakening Party); founded in 1998, and based largely on an NU constituency

: Partai Komunis Indonesia (Indonesian Communist Party)

: Partai Keadilan Sejahtera (Justice Prosperous Party), an Islamic modernist party

: Palestinian Liberation Front, founded in 1964

: Partai Nasional Indonesia (Indonesian Nationalist Party)

: Central Axis

: Partai Persatuan Pembangunan (United Development Party), an Islamic political party

: the traditional aristocratic class of Java

: 'Reform'; the post-new order period

: Pious Muslims

: a process to call nominal Muslims to be pious Muslims

: Islamic Association; founded in 1912

: Islamic law

: Faction, party; the second largest branch of Islam after Sunni

: Majority branch of Islam

: One of the four madzhab of Sunni Islam, and the dominant school of Indonesia's traditionalist Muslims

: United Nations General Assembly

: United Nations Security Council 


\section{CHAPTER ONE \\ INTRODUCTION}

\section{Background}

The world has seen increasing discussion regarding the relationship between Islam and politics, including the role of Islam in foreign policy making in Muslim majority countries. The 9/11 tragedy and other global terrorist phenomena have pushed Islam and Muslim countries into the centre of the world's spotlight. Indonesia has also been caught up in this limelight. The state has frequently been portrayed as having a distinct kind of Islam compared to other Muslim countries. It has been described as a country where Islam and democracy can evolve together (Bush, 2009).

Indonesia's population is approximately 252 million, 87.2 percent of whom are Muslims (BPS, 2015). As a Muslim majority country, Indonesia has never formally defined itself as neither an Islamic nor a secular state, but rather as a Pancasila state. Having Pancasila state status has led to political dynamics in the relationship between Islam and politics and between Islam and the state since the formative era of modern Indonesia. It is important to study the relationship between Islam and politics in Indonesia, including aspects connected with foreign policy. Therefore, this thesis aims to study the role of Islam in the contemporary foreign policy of Indonesia, one of the world's most important Muslim majority countries.

This thesis is important for at least two reasons. First, it is set against a backdrop of existing scholarship which has suggested that, in an earlier period, Islam has not played a prominent role in Indonesia's foreign policy. Second, over the last decade and a half Indonesia has experienced a democratic transition that since 2004 has arguably become a democratic consolidation (Liddle \& Mujani, 2013). This can be expected to have changed the relationship between domestic politics and foreign policy making and may have allowed Muslim groups in Indonesia a greater influence on foreign policy.

Hence, this thesis is focused on the extent to which Muslim opinion in Indonesia on a series of foreign policy issues has translated into a greater say on Indonesia's external stance. It does so in the context of Indonesia's democratisation. This thesis argues that 
Islam (analysed here more specifically in terms of the role of Muslim groups) has a bigger influence on Indonesia's contemporary foreign policy than has commonly been thought. The increased influence of Muslim groups occurs when Muslim groups' aspirations are in line with the aspirations of broader political constituencies. Likewise, this thesis argues that when issues of importance to Muslim groups do not threaten national strategic interests, their influence is more effective. This thesis examines the extent to which the role of Islam has influenced Indonesia's contemporary foreign policy, particularly in the era of President Susilo Bambang Yudhoyono (referred to here as 'Yudhoyono').

This thesis has investigated the interplay between Muslim groups and the government in the decision making process on international issues of concern to those groups. In studying the cases of the Iranian nuclear programme, the recognition of Kosovo's independence and the Palestinian question, the thesis will employ Putnam's approach which argues that governments need to strike a balance between international interests and and domestic aspirations. However to investigate the interplay between Muslim groups and the government in the broader context of the differentiation between authoritarianism and democratisation, this thesis will use Skidmore and Hudson's statist-pluralist (societal) approach. This approach manages to capture state-societal relationships in democratic conditions while Putnam does not differentiate between democratic and authoritarian states.

A literature review for this thesis needs to consider a range of issues and connections. First, there is the literature review on foreign policy making and the relationship between domestic and external political concerns. The second part of the literature review considers the relationship between religion and foreign policy. A particular aspect of this review considers the scholarship on the role of Islam in the foreign policy of Muslim majority countries. The fourth part of the review looks at research on the more specific question of the role of Islam in Indonesia's foreign policy. On the basis of this overall literature review, the specific contribution that this thesis makes to the scholarship will then be discussed by way of outlining and explaining the thesis's research objectives.

This will be followed by an explanation of the research methodology which has been adopted, including the use of case studies which evaluate the role of Islam in Indonesia's contemporary foreign policy as it applies to three important foreign policy issues relating 
to the interests of Muslims. The data used for this research will also be discussed, along with some of the limitations of the research. This will be followed by a guide to the overall structure of the thesis.

\section{Literature Review}

\subsection{Foreign policy formation}

Foreign policy is naturally the domain of the state, meaning it is state-centric in nature (Webber \& Smith, 2002, p. 16). Like domestic policy, foreign policy is set and formulated within the state, yet it is intended for and implemented in the "environment external to that state" (Clarke \& White, 1989, p. 5). Foreign policy is, according to Wallace (1971), an "area of politics which bridges all the important boundaries between the nation-state and its international environment" (p. 7). On the one hand, foreign policy is regarded as an overt plan of action set to secure a country's specific external goals (Clarke \& White, 1989). It consists of guidelines for a state concerning its external affairs or specific international issues of concern (Gindarsah, 2012a). On the other hand, it is also viewed as a series of habitual responses by a state to affairs or events that take place in the international milieu. This reflects two conceptions of foreign policy. First there is the conception that it is related to state activism. The second is the notion that views policy as a substantially structured reaction to the external environment (Clarke \& White, 1989).

Realism has greatly influenced the study of foreign policy. Realism is the most mature and well-established theory in the International Relations discipline (Steans \& Pettiford, 2001, p. 20). Within the realist tradition, neoclassical realism is a relatively recent theory. It combines the key features of classical realism and neorealism (Gindarsah, 2012a). It represents "an imperfect transmission belt" between systemic incentives and constraints and unit level behaviour, namely actual foreign policy practice (Taliaferro, Lobell, \& Ripsman, 2009, p. 4). Its foreign policy model places the domestic politics of a state as an intervening variable between systemic constraints and incentives and the state's decisions and implementation (Gindarsah, 2012a). However, like the other variants of realism, neoclassical realism shares the assumption that external politics are a constant struggle among states to pursue material power and security in an uncertain world with scarce resources (Taliaferro et al., 2009). Despite its emphasis on the primacy of the international system, neoclassical realism acknowledges the salience of domestic political factors and 
the perceptions of leaders concerning foreign policy responses to the external environment (Ripsman, Taliaferro, \& Lobell, 2009).

Neoclassical realism seemingly narrows the gap between the other variants of realism and liberalism particularly in relation to the importance of domestic politics in foreign policy. Classical and neo realists believe the domestic dynamic plays a modest role in foreign policy. Both focus on power politics, the state's behaviour in the international system, the rationality of the state as a unitary actor, and the distribution of power. However, in general, due to their acknowledgement of the primacy of the international system, realists argue that a state's behaviour is not determined by domestic factors such as religion, ideology, and culture. Instead, a state's behaviour is shaped by its national material interests and power maximisation (Haque, 2003). On the other hand, the liberal approach acknowledges the salience of domestic politics in foreign policy. It does not consider the state as a rationally acting unitary actor. It stresses the importance of non-state actors in foreign policy. Liberals view interest groups including religious and societal groups and the public as important actors influencing the state's foreign policy. Therefore, the national interests of states are determined by interest groups and the public, as well as by government authorities. Despite their acknowledgement of the salience of domestic politics, proponents of liberalism have different views on how much and in what ways domestic politics affect foreign policy (Griffiths, 1999).

Hill (2003, p. 37) argues that foreign policy cannot be separated from the domestic context where it develops. He believes there would be no foreign policy in the absence of domestic society and the state. His argument does not pretend to negate the realist perception that international politics cannot be separated from the international system. According to Hill (2003), foreign policy should not be associated with "a game like chess, with rules, a single dominant value, and unitary, optimizing decision maker" (Hill, 2003, p. 37). Therefore, the framework Putnam (1988) sets out is a more realistic approach. Putnam proposes the two-level game approach where a government plays politics simultaneously on two boards, the domestic and international (Hill, 2003; Putnam, 1988).

The two-level game as discussed by Moravcsik (1997) follows the notion that "the relationships of states to the domestic and transnational social context in which they are embedded have a fundamental impact on state behaviour in world politics" (p. 513). The 
two-level game establishes a linkage between the domestic and international political dynamic (Putnam, 1988). In the domestic context, domestic constituencies put pressure on the government to adopt and implement policies they favour. On the other hand, the government also seeks power and legitimacy by making political coalitions among its constituencies. Meanwhile, at the international level, the government seeks to accommodate domestic aspirations while minimising the adverse impacts on external relations. In this vein, political leaders should concurrently play the game at both the international and the domestic levels (Putnam, 1988). The need for decision makers to satisfy both domestic constituencies and international players leads to constraints on foreign policy behaviour (Dosch, 2006; Putnam, 1988).

Hagan (1995) further develops Putnam's approach on the interaction and linkages between the domestic and external environment. He argues that the linkages and interaction may provide two types of objectives in domestic politics, namely: establishing political coalitions and retaining political power (Hagan, 1995). In the first objective, foreign policy decision makers need domestic political support to build political coalitions for the sake of implementing any policy initiatives. Foreign policy decisions constitute political results reflecting "the political strategies necessary to build agreement" with the domestic structure so as to support the implementation of policy initiatives (Hagan, 1995, p. 122). Meanwhile, the second objective requires decision makers to adjust themselves to find ways in order to impose fewer domestic political risks. Such action is carried out by political leaders or government to retain power (Hagan, 1995). In many developing countries, retaining political power is more prevalent than building political coalitions (Perwita, 2007, p. 183).

Dosch (2006) argues Putnam's two-level approach has conceptual shortcomings as it does not elucidate the impact of domestic factors on foreign policy in different types of regimes. There is no differentiation between democratic and autocratic regimes (Dosch, 2006). Putnam's approach also does not touch on the potentially differing relationships between the state and society in weak states and strong states. The statist and pluralist approach of Skidmore and Hudson (1993) may address the shortcomings of Putnam's approach by dealing with the relationship between the state and society in both autocratic states and democratic states. 
The statist approach assumes that the state has full autonomy in conducting foreign policy. This condition may be found in non-democratic states, where the government formulates foreign policy largely autonomously from the influence of society. The state is much stronger than society and therefore it can neglect the role of society. Foreign policy formulation is determined by national interests as calculated by elites. As reflected in the foreign policy of some strong states, this approach assumes that national interests are defined either subjectively or objectively depending on the regime's views. Meanwhile, the pluralist approach assumes that the society within the state has a salient role in foreign policy. This approach comes with the assumption that to maintain and maximise their influence and effectiveness in foreign policy, "the political leaders care most about maintaining a high level of domestic political support" (Skidmore \& Hudson, 1993, p. 9).

Considering the types of cases and the kind of international issues discussed in this thesis, it was decided to employ Putnam's (1988) two level game approach and the statistpluralist approach of Skidmore and Hudson (1993). There are two reasons why these two theories are important and relevant to this my thesis. First, Putnam's approach helps craft a framework to analyse Indonesia's foreign policy behaviour as a result of the interaction between the government and Muslim groups on issues which will be discussed in the thesis. Here, the government needs to set policies which strike a balance between the views of Muslim groups and international interests and pressures. Second, the Skidmore and Hudson approach helps investigate the importance of Muslim groups in Indonesia's foreign policy making both in the pre- and post-Suharto eras. In a more general sense, Putnam's approach provides the context of the interaction and linkages between the domestic and external environment influencing a state's foreign policy behaviour, while the Skidmore and Hudson approach is aimed at capturing the interplay between state and societal groups. To give a clear map on foreign policy actors, especially non state actors in a democratic state such as Indonesia, it is first worth reviewing the work of Coplin (1971, p. 77). Through his work this thesis intends to discern groups competing to influence foreign policy formulation in a contemporary Indonesia. According to Coplin (1971), there are four groups that have the capability to influence foreign policy, namely government officials or the executive, partisan (political parties), public opinion, and interest groups including societal and religious organisations (Coplin, 1971, pp. 70-78). 
This thesis will mainly focus on interest groups, and especially on Muslim groups. It will also give emphasis to other groups, namely partisan groups and public opinion. The term 'interest group' refers to a group of individuals with common interests on economic and non-economic aspirations (Coplin, 1971, p. 75). In Indonesia, religious organisations such as Muhammadiyah and Nahdlatul Ulama (NU) belong to this category. Meanwhile public opinon consists of public discourse in the public domain. In this vein, Muslim groups' aspirations may be channelled through news and articles or programmes in mass media (Gindarsah, 2012a, p. 419).

Partisan groups, especially Islamic political parties, may also transmit the aspirations of Indonesian Muslim groups to become stronger voices in influencing foreign policy. Indeed, political parties may play a role in linking societal groups and the political leadership whilst also being themselves part of the government (Kaarbo, Lantis, \& Beasley, 2002). Despite emphasising the role of Muslim groups as interest groups, this thesis cannot avoid also emphasising political parties, especially Islamic parties which as formal organisations often channel Muslim groups' political aspirations. As Indonesian Muslim groups and Islamic political parties directly or indirectly associated themselves with religion of Islam, it follows that all Muslim groups as mentioned in this thesis have a religious context. For example, NU and Muhammadiyah are commonly understood as religious (Islamic) mass organisations. Further, this thesis defines religion in a sociological manner where religion and society cannot be separated. In this vein, a religion, as defined by Durkheim (2001) is "a unified system of beliefs and practices relative to sacred things, that is to say, things set apart and forbidden-beliefs and practices which unite into one single moral community called a Church, all those who adhere to them" (pp. 14-15). Therefore the origin, function, and meaning of religion can only be comprehended and explained by alluding to community or social elements (Cristi, 2001). This sociological approach to religion is useful in understanding that religious organizations exist to cultivate religious interests. Religious organisations ensure "religious ideas, attitudes and feelings are given stable social expression" representing social relationships within the community (James, 1973).

In the context of Indonesia, Muslim groups including Muslim political organisations may gain much attention from the country's policy makers. They are more likely to pay attention and to respond to the aspirations of specific and organised societal groups than to 
society at large (Kaarbo et al., 2002, p. 15). It is impossible to disregard Muslim groups as moral forces in Indonesian politics. However, the extent to which societal groups as interest groups can successfully influence foreign policy depends on the particular issues they take up and their relationship with the government (Kaarbo et al., 2002). Muslim groups are very articulate in voicing certain international issues, especially those that become their concerns such as Palestinian statehood.

For analytical purposes, Muslim groups are categorised by this thesis into moderate and militant/radical Muslim groups. The moderates are classified into traditional groups, which are commonly associated with $\mathrm{NU}$, and modernist groups which are commonly represented by Muhammadiyah. Meanwhile, the second group consists of militant/radical Muslim groups or Islamist groups. The latter has been further divided into political groups such as Hizbut Tahrir Indonesia (HTI) and Majelis Mujahidin Indonesia or MMI (Indonesian Islamic Warrior Council); dakwah (missionary) groups such as Jamaah Tabligh and Salafi movements; and jihadist Islamist groups such as Laskar Jihad and Jamaah Islamiyah (Weck, Hassan, \& Abubakar, 2011).

This thesis will contend that the societal factor ${ }^{1}$ is a crucial independent variable shaping foreign policy making and behaviour. The author works from the assumption that society at the domestic level gives input to the government and therefore influences its decisionmaking process and implementation.

\subsection{Religion and foreign policy}

Religion has been marginalised in international politics since the emergence of modernity. The state's supremacy under the Westphalian system led to increased religious marginalisation (Dark, 2000; Fox \& Sandler, 2004; Hatzopoulos \& Petito, 2003; Thomas, 2005). Prior to the 1979 Islamic Revolution in Iran, modernity made secularism relatively unchallenged for centuries. The most shocking challenge for modernity was the 9/11 terrorist attacks (Philpott, 2002). Since the 1970s, there had been a re-awakening of religion (Swatos, 1989), but this had gone largely unnoticed in IR scholarship. The attacks

\footnotetext{
${ }^{1}$ All elements of society including religious groups which have interests in international issues and which constitute stakeholders in foreign policy can be categorized as examples of societal factors which shape and influence the foreign policy of a country. In theorical terms, the societal factor in foreign policy includes the political culture and the system of belief, history and social structure (Perwita, 2007).
} 
in New York on 11 September (9/11) raised awareness of the important role of religion in international politics.

The global phenomenon of the rise of religion suggests that it has survived modernity (Berger, 1999). This challenges the understanding of the modern world and has marked the return of religion to world politics. Therefore, scholars like Thomas (2005), Fox and Sandler (2004), Hatzopoulos and Petito (2003), and Philpott (2002) advocate bringing religion back into the literature on international relations. Their proposal is not to change the existing international political paradigm but instead to include religion as a variable.

Studying religion and foreign policy leads to a series of questions; what are the conspicuous impacts of religion on foreign policy and what is the possible mechanism for the influence of religion on foreign policy? According to Warner and Walker (2011), studies on this subject have still left those questions unanswered. Indeed, it is a difficult task to answer them. The role of religion in this regard is mostly related to the function of religion in terms of its theological aspects, attribution to a culture, and a basis of values (Philpott, 2007).

Philpott (2007), Warner and Walker (2011), and Manza and Wright (2003) suggest that we should not ignore the role of religion as an attribute of individuals and communities and its role in institutional relations within a state. Both religious legitimacy and religion as a human worldview might also need consideration (Fox \& Sandler, 2004). Religious legitimacy relates to the function of religion in justifying politics and international relations. Religion's influence on foreign policy is related to its ability to shape public opinion (Baumgartner, Francia, \& Morris, 2008; Wuthnow \& Lewis, 2008) to contain core elements of identity (Croft, 2009) and to generate soft power characteristics (Haynes, 2008).

The role of religion in international relations has been given relatively little attention by scholars as a factor shaping attitudes towards foreign policy. Scholars have focused more on the role of religion in domestic politics (Cahill, 2009; Jones-Correa \& Leal, 2001; Patrikios, 2008; Putnam \& Campbell, 2010; Shankland, 2007; Wald \& Brown, 2011; Wilcox, 1990), especially in electoral behaviour in the US and other countries (Bélanger \& Eagles, 2006; Don-Yehiya, 1997; Green, 2007; Haqqani, 2004; Manza \& Brooks, 1997; Minkenberg, 2010; Stan \& Turcescu, 2005). 
The imperative role of religion in domestic politics is found not only in non-Western countries but also in the West. This review on religion and foreign policy will draw heavily from the US literature. The US provides a political laboratory on religion and politics including foreign policy, as religious groups play a distinctive role in US politics. Despite the US political and legal traditions separating church and state, the US has strong religious elements compared to other Western countries. Only 6.3 percent of Americans regard themselves as 'secular' and unaffiliated with any religion (Cahill, 2009). Religious leaders and religious groups actively engage in political life. US elections have been influenced by religious factors since at least 1896 (Gentile, 2008). The religious affiliations of political candidates are often scrutinised (Cahill, 2009).

Studies by Minkenberg (2010) and Dalton ( 2008. ) investigate the declining importance of religiosity in politics among Western democracies, including the US. However, Minkenberg (2010) acknowledges that religion, and religious groups, have remained a political force in Western democracies. Religious factors have been largely neglected as a dimension in analysing foreign policy. Religion was not considered salient in this field before 9/11 (Marsden, 2011). Jelen (1994) and Ribuffo (1998) for example, suggest that religion had an insignificant effect on US foreign policy. Jelen (1994) observed the effects of religious belief on the orientation of foreign policy and on people's attitudes towards the Gulf War, but concluded that the role of religion in decision making was limited. There was "little evidence that religion affects foreign policy in a systematic manner" (Jelen, 1994, p. 392). This would suggest that there is no need to assume the importance of religion in the foreign policy making process. Meanwhile, Ribuffo (1998) was unable to find any major US diplomatic decision that was motivated only by religious issues. He argues that religious issues are far less important than strategic, economic, and political considerations.

The 9/11 terrorist attacks and the close association of President George W. Bush with Evangelical Protestantism forced commentators to reconsider religion as a significant contribution to international politics (Marsden, 2011). Bush's genuine personal religiosity greatly affected US foreign policy. Bush's religious beliefs combined with a secular neoconservative ideology dominated the attitudes of US foreign policy from 2001-2008. In the aftermath of 9/11, religion served as an instrument which provided moral justification and legitimisation for US foreign policy (Bacevich \& Prodromou, 2004). Although Bush's 
religious influence on foreign policy was considered dangerous by some scholars such as Wallis (2004), Bush gained support from religious domestic constituents (Baumgartner et al., 2008; Friedman, 2009; Froese \& Mencken, 2009; Haynes, 2008; Smidt, 2005).

In the post-Bush era, religion has still had a significant role. Marsden (2011) argues that President Barack Obama has also employed religion to optimise domestic support for foreign policy initiatives such as on Middle Eastern issues, seeking to maintain US global supremacy through more consensual and multilateral approaches than those of President Bush. The Obama administration has provided an opportunity for religious actors to continuously play a pivotal role in pushing US interests abroad.

Religion has a potent power in foreign policy. Religion indeed contains many core elements of identity. Such elements of identity are not only seen prominently in Islamic countries such as Iran and Pakistan but also in Western countries such as the US (Croft, 2009). However, the discourse on religious identity and foreign policy has gained little attention from scholars.

In general, the above studies demonstrate the importance of religion in domestic politics, mostly related to electoral attitudes and US foreign policy, particularly in the aftermath of the 9/11 attacks. Religious issues have also been utilised by the government of the US to serve domestic constituencies. Religion clearly plays a role in US foreign policy toward the Middle East, particularly in relation to Israel (Guth, 2012; Miller, 2014). Religion has also been utilised by the US government for power legitimacy and justification. President Bush successfully used religious ideology to justify and to gain support for his foreign policy in the Middle East, particularly the invasion of Iraq (Silk, 2012). However, much of the scholarship does not provide elaborate accounts as to exactly how religion influences US foreign policy.

It is not only in the US that religion influences foreign policy but also in other Western secular states such as Russia. Russian foreign policy has also been influenced by domestic interest groups including the Russian Orthodox Church (ROC) (Blitt, 2010; Curanovic, 2014; Lomagin, 2012). As Russia's majority religious group, the ROC has influenced the government to reassess the state's secular constitutional status and state-church relations. The growing influence of the church becomes obvious as it goes beyond the realm of domestic policies. The state and the church have supported one another in terms of foreign 
policy goals. The church has the ear of the government in the foreign policy making process (Blitt, 2010). The past Medvedev-Putin government established an open-ended concept of spirituality in its policies, including its national security policy. This policy is embodied by its exclusive espousal of Russian Orthodox values. Rhetorically, this espousal of ROC values aims to cement Russian nationalism. The Russian government followed this with practical steps in the field of foreign policy. The views of the Moscow patriarchate have been integrated into the formulation and implementation of Russia's foreign affairs (Blitt, 2010). The ROC's most important role is its support for the rise of a new Russian nationalist identity underlying the country's foreign policy (Lomagin, 2012). In short, religion is an important factor in Russia's foreign policy, even if, as Curanovic notes, the importance of the religious factor has been neglected in the literature on the country's standpoint on international issues (Curanovic, 2014).

The literature on the US and Russia, at least to some extent, illustrates the relationship between the state and religious organizations with the latter acting as interest groups on foreign policy issues in both countries. In the US, for example, religious organizations have played an important role in relation to humanitarian aid with regard to USAID. The literature provides us with insights into how to study the influence of religious organizations on foreign policy. Although not specifically elaborated in this Russia-US literature, it is useful for this thesis to look further at the influence of Muslim groups on Indonesian foreign policy.

\subsection{Islam and foreign policy of Muslim states}

Studies of Islam and foreign policy in predominantly Muslim countries have commonly focussed on the cases of Turkey, Iran, Pakistan, and other countries in the Middle East and the Caspian region. We can divide these countries into two general categories. The first are Islamic states and the second are Muslim secular states. Islamic states depart from the concept that there is no separation between religion ( $\mathrm{ad} \mathrm{din)}$ and the state (ad dawlah). Islam is believed to contain the comprehensive holistic manner (kaffah) teachings (Azra, 2006, p. 7) which can be applied in all aspects of life, including in the political field. Thus, Islam in its entirety offers a solution to all problems, including familial, socio-cultural, economic, and political matters (Effendy, 2003, p. 34). In this regard, Islamic states are rooted in Islamic law which they claim to uphold (An Na'im, 2008). Some Islamic states at present have also adopted modern political institutions such as elections and popular 
sovereignty. On the other hand, secular Muslim states adopt an institutional separation between Islam and the state. This separation will not necessarily sever the connection between Islam and politics; such states may still allow the implementation of Islamic principles in their policies and legislation. Theoretically, however, there should be no favouritism to any religious doctrine and principles. The state's religious neutrality is essential. By following these principles, Muslim secular states will not forcefully implement Islamic law (An Na'im, 2008).

The extent to which Islam influences foreign policy is subject to debate. It is said by some scholars such as Shaffer (2006a) and Cornell (2006) that religion has no clout in shaping foreign policy. Even in Islamic countries like Iran, Saudi Arabia, and Pakistan, religion is not the sole influence on foreign policy decision making. Instead, foreign policy has generally been subject to pragmatism based on domestic needs and national interests. Those countries often show discrepancies between their official ideology and their foreign policy (Cornell, 2006; Flanagan, 2009; Piscatori, 1983; Shaffer, 2002, 2006b).

Iran, for example, has preferred security and economic considerations to religious considerations in its foreign policy toward Caspian countries (Shaffer, 2002, 2006b). Like Shaffer (2006b), Flanagan (2009) argues that Iran's foreign policy emphasises realist principles, power politics and the country's survival at the expense of Islam and religious principles. Iran's foreign policy works at both the domestic and international systemic levels. President Ahmadinejad's radical foreign policy towards the West had also developed because of Iran's realist nature and pragmatism, i.e. pursuing political power and enhancing the state's economic power. Consequently, Iran often embraces religious rhetoric to balance domestic aspirations and its real interests (Flanagan, 2009; Shaffer, 2002, 2006b).

Iran's pragmatic foreign policy has been more evident under President Hassan Rouhani. His reputation as a pragmatic and moderate figure has greatly shaped Iran's new diplomatic posture (Sherrill, 2014; Terhallea, 2015; Zarif, 2014). This diplomatic posture has achieved remarkable progress in Iran's nuclear negotiations, in which Iran and the P5+1 reached a nuclear agreement in July 2015 (Katzman \& Kerr, 2015).

Some scholars disagree with the argument that Islam has an insignificant role in Iran's foreign policy. Nia (2010), Anshari (2006) and Monshipouri (2013) argue that Islamic 
ideology constitutes a salient factor in Iranian foreign policy as Iran has a commitment to promoting Shiite ideology and at the same pursuing its pragmatic national interests. Iran's Islamic ideology and material national interests are interlinked with its foreign policy. Other states tend to view Iran's Islamic orientation and its national interests as synonymous. Countries like the US have had a tendency to view Iran in religious and revolutionary terms, and set up their foreign policies toward the state accordingly (Anshari, 2006).

The projection of Iran's pragmatic and moderate foreign policy by the Rouhani administration - aiming to restore its relations with the world - has not meant that Iran has avoided the use of its cultural identity (originating from the blend of Iranian and Islamic culture) in seeking its national interest. Iran has utilised its cultural identity to promote "its mission and message throughout the entire Islamic world" (Zarif, 2014, p. 3). Moreover, the final authority of Iran's foreign policy is still under the hand of the Iranian Supreme Leader, Grand Ayatollah Ali Khamenei (Sherrill, 2014), meaning that Iran's foreign policy under Rouhani is always intertwined with Islamic ideology. The Supreme Leader has a primary interest in maintaining the existence of the Islamic system of Iran (Sherrill, 2014).

Similar observations of Islam's role in the foreign policy of an Islamic state can be seen in Pakistan. According to Cornell (2006), Pakistan's foreign policy has largely been motivated by pragmatic considerations. Islamic ideology as the basis of Pakistan's policies such as its support for Islamic causes has been partly done for the sake of serving the country's material national interests. The country has often mixed genuine solidarity with pragmatic ends with regard to Islamic causes. Islam is a salient factor as it provides a basis for the cohesive identity of the Pakistani people. Therefore, the foremost challenge for Pakistan's foreign policy is to maintain a delicate balance between Islamic ideology and practical considerations (A. S. Khan, 2006).

Cornell (2006) states that the establishment of Pakistan as an Islamic state as enshrined in its 1956 constitution might be based on material and ideological desires. Despite being encouraged mostly by pragmatic ideas, the Pakistani leaders avoid contradictory actions against the Islamic orientation of the state. Contradictions in this matter could lead to domestic political risks. In other words, cultural (Islamic) factors become constraints for foreign policy choices. In cases in which the costs are not politically high, Pakistan utilises 
opportunities to prove its Islamic identity. In terms of alliances, Pakistan has no preferences as long as it gains benefits from its partners. It disregards the cultural basis or ideological alignment of potential partners.

Nevertheless, religion's role in Pakistan's foreign policy cannot be ignored. An earlier study by Delvoie (1996) shows that the 'Islamization' of Pakistan's foreign policy occurred as soon as President Ali Bhutto came into power in 1971 and Pakistan tried to take a lead in the Organization of Islamic Cooperation (OIC). Pakistan's efforts culminated in the hosting of the OIC Summit for the first time in 1974. The country also increasingly cemented its relations with Arab countries and other Muslim states. Even in the era of Nawaz Sharif, Pakistan took a lead in the UN peacekeeping force in Somalia and Bosnia in the name of Muslim solidarity. Pakistan has also continued to place the Kashmir issue in the central agenda of its foreign policy. Previously characterised as a mere territorial conflict (since the 1990s), Pakistan now attributes the conflict to religious affiliations. By doing so, Pakistan wants to show its inclination "to rest at least one major part of their foreign policy on Islamic ideology and Muslim solidarity" (Delvoie, 1996, p. 141). Another important role of the religious element in Pakistan's foreign policy might be seen in the background of crafting an ideology based on Islamic Pakistani identity. This has been intended to counteract the perceived threat from India and to separate it from "an Indian South Asian identity" (Pande, 2010, p. xi).

Based on earlier discussions, we might conclude that religion has far less influence in the foreign policy of Muslim secular states than of Islamic states. In fact, most Muslim states are secular states. Turkey and Indonesia are among the Muslim secular states that often receive attention from scholars of foreign policy.

Turkey's politics have attracted the attention of scholars as they highlight the tension between 'secularism and Islam' or 'Eastern versus Western' perspectives (Taspinar, 2011). Secularist or Kemalist thinking has sought to control religion (Islam) without demolishing it. Religious ideology was excluded from the nation building process in Turkey. The secularists commonly imposed their identity and ideology on Islamists. The successive victories of the AKP Islamist party in the 2002, 2007, 2011, and 2015 elections have made secularists feel threatened. They think that the AKP leaders have begun to establish a nonsecular, or theocratic state (BBC, 2015; Toprak, Uslu, \& Yilmaz, 2011). This concern of 
the secularists is not baseless. Since the AKP took power in 2002, debates about Islamization have become much more prominent among people and political leaders (Bilgin, 2008).

Jung (2011) and Bilgin (2008) deny that Turkey's foreign policy has changed substantially under the AKP. Turkish foreign policy under the AKP party is still within the confines of historical patterns of foreign policy under previous administrations in the Turkish Republic (Dalay \& Friedman, 2013). Islam has been used as a symbolic resource by various governments. Hence, the AKP administration policy is also in line with the notion of the instrumental use of religion (Jung, 2011). The AKP does not stress Islam and persistently denies its status as an Islamist political party (Bilgin, 2008; Cornell, 2012).

However, some scholars argue that Turkey's foreign policy has undergone a transformation during the AKP government. Its foreign policy has promoted soft power that might intend to decrease the influence of its armed forces, domestically and internationally (Jung, 2011). The transformation has been more concerned about the foreign policy decision making process and democratisation. It has had less to do with the ideological reorientation, and de-Europeanisation or Middle-Easternisation of foreign policy (Kanat, 2010). In Turkey's foreign policy, Islam has a limited role. Its functions are only to justify and conceal the real motives of the country's foreign policy. Islamic motivations provide only an insignificant part of Turkey's foreign policy toward the Middle East. Political interests in thesecases supersede ideological considerations (Bilgin, 2008).

Cornell (2012) and Onis (2009) argue that the AKP's first period (2002-07) under Prime Minister Abdullah Gul put an emphasis on EU harmonisation as a vehicle to join the EU. Starting in the second period of the AKP administration under Prime Minister Recep Tayyip Erdoğan, there has been a substantial shift from this course. Ankara reoriented its focus from the West to the East, emphasising its more immediate neighbourhood under the slogan: 'zero-problems with neighbours' (M. S. Khan, 2015). This notion has been espoused by Warning and Kardas (2011), who conclude that Turkey's identity has moved from a Western secular one to a Turkish Islamic one. The shift of Turkey's identity has affected all aspects of the country's social and political life including its foreign policy. 
Originally Western-oriented, Turkish foreign policy has paid more attention to the Middle East and other Islamic states including those in the Balkans since the AKP in power.

The AKP leaders' Islamic worldview has contributed to the shape of Turkey's current foreign policy, which shows increasing interest in Islamic matters. Turkey's gradual shift away from the West to the East, its hard-line stance against Israel, its support for Hamas, and other similar policies show us the noticeable influence of the AKP leadership's Islamic ideology and of Muslim constituents on recent Turkish foreign policy (Aghsan, 2011; Aras, 2009, 2014; Cornell, 2012).

Another secular Muslim country is Malaysia, a neighbour of Indonesia. Islam, as the official religion of Malaysia, has greatly influenced the country's political landscape. Islam has been a part of Malay political culture and a component of its identity since the independence of Malaysia (Nair, 1997; Robani, 2010). It has become a symbol of legitimacy in Malaysian politics. Malaysia has demonstrated its concern for and solidarity with Muslim causes to the entire world, especially on the Palestinian issue. However, Malaysian government policy on the Palestinian issue was largely driven by pragmatic considerations as a result of the interplay between political, economic, religious, and humanitarian factors (Robani, 2010). On the other hand, Kutaisha (2006) argues that Islam is a salient factor in Malaysia's foreign policy. This was especially so during the premiership of Dr Mahathir Mohamad. Islam was not only a crucial driving force in foreign policy but also an important factor in enhancing economic relations. Kutaisha (2006) observes the role of Mahathir Mohammad who promoted Islam as one of the elements of Malaysian foreign policy. However, Saravanamutu (2010) argues that despite its presence since independence, Islam played a salient role only since the last decades of Mahathir's rule. This important role of Islam has seemed to continue in the post Mahathir era. In response to the World's misperception after the 9/11 tragedy, Malaysia came up with the concept of Islam Hadhari (civilised Islam) which has placed Islam in the center of its public diplomacy.

Having observed both Islamic states and secular Muslim ones, it generally appears that religious ideology and religious groups are not the sole motivating force behind foreign policy. However, religion is undeniably one of the elements shaping foreign policy in Muslim countries of both an Islamic and secular variety. The degree to which religion 
influences foreign policy in every country is varied, and can only be analysed on a caseby-case basis.

The literature on Turkey, Iran, and Malaysia, to some extent, generally describes the state as a monolithic actor. It barely discusses how Muslim groups or organisations influence foreign policies. The way domestic politics shape the degree to which religion influences foreign policy is not particularly elaborated on. As the state, comprised mainly of the government, is seen as a monolithic actor, the discussion on the role of religion is placed in the context of elite policy making. These studies hardly mention the state-society relationship. This thesis will seek to fill that gap in the literature by focusing on the relationship between the state (the government of Indonesia) and Muslim groups in the context of Indonesia's foreign policy. In going beyond treatment of the state as a single actor, this thesis recognises the interplay between the state and non-state domestic actors, particularly Muslim groups, in foreign policy formulation. As interest groups, Muslim groups in Indonesia are greatly concerned about Muslim issues in both domestic and foreign contexts.

The above literature also demonstrates how religion has been utilised by Muslim states' governments for power legitimacy and justification. This features prominently in Turkish and Iranian foreign policies. Unlike in the US, religious solidarity and sentiments are more prevalent in Islamic literature and the foreign policies of Turkey, Iran, Pakistan, and Malaysia. This might be related to the concept of the Muslim ummah. The term "Ummah" is generally understood as the community of believers in the religion of Islam. The ummah encompasses the entire Muslim world. Thus Islamic sentiments or solidarity are part of Islamic life. However, the degree of Islamic solidarity varies among Muslim countries in the state sphere. Islamic states such as Iran and Pakistan might have a stronger sense of Islamic solidarity than secular Muslim states such as Turkey, Indonesia, and Malaysia.

Islam in Indonesia's foreign policy might be expected, to some extent, to share a similar pattern with other Muslim secular states, particularly Turkey and Malaysia. Muslim secular states, compared to Islamic states, often face challenges on how to set up balanced policies within the delicate relationship between Islamic ideas, Muslim groups, and the state. The state must balance how to attain national material interest, how to maintain a status of secular identity, and how to accommodate Muslim people's aspirations. In this 
regard, questions are frequently raised as to what degree the policies of Muslim secular states' governments accommodate Muslim people's aspirations. Are these policies rhetoric or substantial? Another question may emerge with regard to the function of religion for power legitimacy and justification in the context of Indonesia. Is Islam used to legitimise and justify Indonesian foreign policy? Another related question is: Does Indonesia share the same phenomenon with other Muslim countries, particularly Iran, Turkey, and Pakistan in terms of using Islam as a political instrument? If we look at domestic politics in the Suharto era, we can see that Suharto utilised Islam as a tool for his domestic political purposes (Liddle, 1996; Tirtosudarmo, 1992a). In the last years of Suharto's administration, the relationship between Islam and the state became closer. Suharto's increasing closeness to Muslims at that time was perceived to balance his influence among military and Indonesian Muslim groups. The subsequent portion of this chapter will review the existing literature on the role of Islam in Indonesian foreign policy which focuses mainly on the Suharto era.

\subsection{Islam in Indonesia's foreign policy}

Generally, scholars have focused on Islam and democracy in Indonesia (Azra, 2006; Hefner, 2000; Hilmy, 2010) and the influence of democratisation in Indonesian political life, including foreign policy (Anwar, 2010a, 2010b; Dosch, 2006; Gindarsah, 2012a). Only a few studies solely address the relationship between Islam and foreign policy. Islam and Indonesia's domestic politics are inseparable. Given the extent to which the relationship between Islam and the state has greatly coloured the dynamic, internal politics of Indonesia, it is not surprising that many works are mainly devoted to studying Islam and domestic politics in Indonesia.

Scholars generally agree that democratisation has substantially impacted on Indonesian politics, including foreign policy. Its status as a democratic country has prompted the country to project its identity as the biggest Muslim democracy (Anwar, 2010b) and to define Indonesia's role in the Muslim world. Indonesia aspires to be a bridge builder between the West and the Muslim world. Indonesia also likes to project itself as a role model for other Muslim countries. However, according to Anwar (2010a), Indonesia should substantiate its claim. It has a long way to go. Indonesia still faces challenges regarding how to realise its projected identity. 
Indonesia's foreign policy has mainly been influenced by external and internal factors such as international pressure and the internal political legitimacy of successive governments, among others (He, 2008). Since democratisation, political legitimacy has become a crucial issue in Indonesian politics. Democratisation has impacted on foreign policy making, structurally and institutionally. It has changed the decision-making process in foreign policy by involving more stakeholders. The regime's accountability has increased, consolidating the government's decision-making power. Democratisation has also enhanced state autonomy and protects it from such forces as the military and cronyism. The way democratic regimes shape their foreign policy, be it the structural or institutional framework, is fundamentally different from that of authoritarian regimes (Dosch, 2006). Structurally or institutionally, Indonesia's autocratic regimes have been shaped by the 1945 Constitution's institutionalisation of a structural framework that gave a very strong role to the president and government agencies in the foreign policy making process. Government agencies, including the military, took the maximum benefits from this structural framework. Meanwhile, democratic regimes open greater opportunities for other foreign policy stakeholders outside the government. The increasing role of non-state domestic actors is also related to "the way in which regime accountability constrains the government's latitude of decision making in foreign affairs" (Dosch, 2006, pp. 46-49).

Taking into account the fact that Indonesia is a predominantly Muslim country, a study of Indonesia's foreign policy in the context of democracy should not neglect Islam as an increasingly important factor. Anwar (2010a) tries to address this concern, however she does not provide details on how Islam influences Indonesia's foreign policy. A study by Gindarsah (2012a) shows us how democratisation offers more opportunity for the public in the foreign policy decision-making process. Focusing on the Iranian nuclear issue, when Indonesia assumed a non-permanent seat on the United Nation Security Council (UNSC) in the period 2007-2008, Gindarsah (2012a) analyses the interplay among various domestic factors, mainly Muslim groups and the parliament. His study provides a good account of the relationship between the state and domestic actors. He mentions that foreign policy making which is against the aspirations of mainstream domestic groups will lead to political risks. Muslim groups and members of parliaments had a significant influence on the Indonesian government's policy change regarding Iran's nuclear policy. However, Gindarsah's study does not specifically discuss the role of Muslim groups including their 
engagement in attempts to influence the government's position on the Iranian nuclear programme.

Generally, the role of Islam in Indonesia's foreign policy is under-studied. Studies of Islam in Indonesia's foreign policy, both under Sukarno and beyond have been conducted by Leifer (1983b) Suryadinata (1995), Sukma (2003), Perwita (2007) and Wicaksana (2012). We may divide these studies into two broad categories. The first are those that provide a comprehensive discussion without necessarily referring to any specific cases. The second are those which offer case study discussions in explaining the role of Islam in Indonesia's foreign policy. The works of Leifer (1983b), Sukma (2003) and Anwar (2010a) are included in the first category while the rest are in the second category.

Leifer (1983b) and Sukma's (2003) studies touch on the problem of a state's ambiguous identity. The role of Islam in this regard was in a matter of functional ambiguity. This ambiguity is a result of the state's identity, which is neither Islamic nor secular. This ambiguity has led to a 'non-religious identity' of Indonesia's foreign policy. Unlike Leifer (1983b), who only examined the role of Islam in Indonesia's foreign policy during the Sukarno and the early Suharto eras, Sukma (2003) provides a broader account. He examines the role of Islam from the Sukarno era up to the early period of the Megawati presidency.

Suryadinata (1995) and Perwita (2007) focus on Islam and Suharto's foreign policy, using a case study approach. Suryadinata utilises case studies of Indonesia's policy towards the Middle-East and Bosnia. Meanwhile, Perwita (2007) uses four different cases occurring during the Suharto era, namely: Indonesia's relations with the OIC; the Middle-East issue; the Moro problem; and the Bosnia-Herzegovina war. In addition, as a postscript, Perwita (2007) also provides an overview on Islam and Indonesia's foreign policy beyond Suharto, employing the state-society relations approach proposed by Skidmore and Hudson (1993). Having examined the above cases, both Suryadinata (1995) and Perwita (2007) conclude that Indonesia's participation and position in the Muslim world were not driven by Islamic sentiments or Islamic solidarity. Instead, Indonesia's foreign policy was based on pragmatic objectives in relation to the domestic and international agenda. For example, Indonesia's role in the Southern Philippines was not based on Islamic solidarity, but on a desire for regional cohesiveness. Regional security and stability was much more important 
than Islamic sentiments (Perwita, 2007). The general conclusion which is presented by Suryadinata (1995) and Perwita (2007) on the marginality of Islam in Indonesia's foreign policy is supported by a recent study by Wicaksana (2012). He reached this conclusion after studying the place of Islam in Indonesia's relations with Pakistan. However, Wicaksana's focus on bilateral relations highlights the role of state or government actors without paying sufficient attention to the interplay between the state and Muslim groups.

Generally, these scholars conclude that Indonesia's foreign policy has rarely been shaped by Islamic considerations. However the non-Islamic character of Indonesia's foreign policy is not necessarily contradictory to Islamic interests. Indonesian foreign policy has not fully served Islamic aspirations, but nor has it produced a predicament for Muslim groups. This policy has been adopted to avoid offence to Muslim society. Foreign policy has entertained Islamic aspirations not in substance but in form (Leifer, 1983b; Perwita, 2007; Sukma, 2003; Suryadinata, 1995).

In addition, domestic pragmatism has required Indonesia to make good relations with nonIslamic states (the West) for the sake of meeting domestic needs, politically and economically (Perwita, 2007; Sukma, 2003). This power structure also led to the low profile of Islam in Indonesia's foreign policy, especially in the Suharto era before the 1990s when Suharto relied on the secular Golkar Party and the military to maintain his grip on power. At that time, Islam was often accused of being anti-Pancasila. The military's fear of Islamic fundamentalists was one of the primary explanations for Indonesia's nonIslamic foreign policy (Sukma, 2003; Suryadinata, 1995).

The state's dual identity and domestic constraints in the form of internal weaknesses in the post-Suharto era continued to be a barrier to the role of Islam in Indonesia's foreign policy. The primacy of domestic pragmatic factors remained an important element determining Indonesia's foreign policy orientation (Sukma, 2003). On the other hand, Perwita (2007) believed that Indonesia's foreign policy would become more influenced by Islamic factors in the years to come, considering the changing political landscape, domestically and internationally. In his more recent study on soft power and public diplomacy, Sukma (2011) suggests that the coming of democracy and the growing importance of Islam have had substantial impacts on Indonesia's foreign policy. However, Indonesia has faced challenges in the way it has incorporated Islam and democracy into its foreign policy. 
Although there is no change in the sense of state dual-identity status in the post Suharto era, this thesis canvasses the possibility that Islam has played a more important role as a result of the advent of democracy in Indonesia. There seems to be a paradigm shift regarding the role of Islam at present and in the future. Unlike previous studies, this thesis argues that post-Suharto political developments have transformed the role of Muslim groups and Islamic political parties. Their role is becoming more evident in Indonesia's foreign policy. Islam might have more substantial influence than it has had in the past. However, that is not to suggest that Islam is the sole factor behind Indonesia's foreign policy.

This thesis focuses on the role of Muslim groups in the foreign policy decision-making process without necessarily neglecting other perspectives, which consider the importance of a leader's religious worldview in shaping Indonesia's foreign policy. The rise of Islam in contemporary Indonesian politics and the diminishing suspicion of 'nationalist' leaders towards Islamist political parties wishing to establish an Islamic state in Indonesia give further opportunity for Muslim groups to have their voice heard both in domestic politics and foreign policy.

As with previous studies on Islam and Indonesian foreign policy, this study places the role of Islam in Indonesian foreign policy in the domestic context. It means that domestic politics create the context for the role and influence of Islam in the country's foreign policy (Sukma, 2003). However, unlike previous studies that do not clearly define 'Islam', this study aims to differentiate between Islam as an ideology or ideas, and Islam as a movement, which touches on the roles of Muslim groups and Islamic parties. This is significant because previous studies and more recent coverage in the existing literature do not properly situate the influence of Muslim groups on Indonesia's foreign policy.

\section{Research methodology}

This thesis employs qualitative research methods and a case study approach. There are many benefits for researchers in utilizing a qualitative research methodology. First, it offers rich descriptions and well-founded rationale to explain social phenomena in their context, and second, it enables researchers to trace historical events, their causes and consequences and come up with insightful explanations to all of these (Mayan, 2001). Qualitative research tends to focus on smaller elements (small N) of people or society. It 
aims to depict the meanings, understandings, and perceptions that individuals and people connect to experiences, behaviours, and social development. This kind of research is quite malleable. It is compliant with a wide range of research methods and forms of data collection (Hennink, Hutter, \& Bailey, 2011; Walter, 2010).

This thesis embraced an interpretive paradigm as it emphasises qualitative methods such as case studies, interviews, and observations. Those methods are suitable to gain an understanding of how human beings interpret the world and their social phenomena (Willis, Jost, \& Nilakanta, 2007, p. 6). Together with positivism, interpretivism is a dominant paradigm in social research. These two paradigms have an opposite orientation (Somekh \& Lewin, 2005). Positivism's central assumption is to explain the world objectively by employing a scientific method (Travers, 2001). Through this method, it is argued, people will come to know the world as it is. Positivism denies relativism and subjectivism and instead, exerts objectivism. On the other hand, interpretivism believes in the distinctions between the natural/physical sciences and social sciences. It acknowledges relativism and subjectivism. The researcher's subjectivity may influence his research objects. There is no divisible separation between the researcher and the reality being investigated. In addition, natural reality differs from social reality. Therefore, the approach demands it necessary that social research have different research methods from that of the natural sciences (Willis et al., 2007).

This thesis employs a case study approach as it is in line with the nature of an interpretative paradigm (Anderson, 1998). The decision to use case studies was based on the fact that the issues discussed in this thesis are post facto (after the event) studies. Berg and Lune (2012) said that "case studies are often adopted for post facto studies, rather than ongoing issues or questions" (p. 326). Case studies are commonly used as a research strategy in the fields of sociology, psychology, political science, social work, business, and community planning (Yin, 2003).

The case study approach can also be applied in various levels and situations. It may potentially contribute to the existing literature and knowledge on individual, group, organisational, social, political, and many other phenomena. In a nutshell, this approach enables us to provide comprehensive and meaningful elements of "real life events such as individual life, organsational behavior, social change, and international relations" (Yin, 
2003, pp. 1-2). Therefore, this approach is important to this study in that it deals with individual, group, institutional, and political phenomena related to the role of Islam in Indonesia's foreign policy.

Gerring (2004) defines a case study as "an intensive study of a single unit for the purpose of understanding a larger class of similar units" (p. 342). Meanwhile, Yin (2003) defines it as "an empirical enquiry that investigates a contemporary phenomenon within its real-life context, especially when the boundaries between phenomenon and context are not clearly evident" (p. 13). Both definitions explicitly indicate that the process of conducting a case study is related to the bounded nature of the case and its contextual setting. As a bounded phenomenon, a case study is very much related to time, location, event, programme, and others indicating the boundaries of a case study's contexts (Cresswell, 2007). Thus, it also helps the researcher to decide the selection of cases in his/her case study.

\subsection{Case selection}

This thesis has chosen as its cases: Indonesia's foreign policies towards the Iranian nuclear issue; the independence of Kosovo; and Palestinian statehood. These three cases are used to explore the role of Islam, and in particular Muslim groups, on Indonesia's foreign policy. This thesis focuses on a range of actors including Muslim religious leaders, religious organisations, mass media, other Muslim civil society and their influence in foreign policy formulation vis-à-vis the state or government's foreign policy agenda.

Referring to definitions of a case study by Gerring (2004) and Yin (2003) this thesis has been confined to cases with some of the following 'boundaries'. First, this thesis focuses on cases which have been of interest to a large proportion of Indonesian Muslims when it comes to Indonesia's foreign policy. These Muslim concerns are indicated by a significant and/or intensive response from Muslim groups that frequently demand that the government takes serious measures according to their aspirations. Second, this thesis has limited the cases to those occurring during the Yudhoyono administration, which offers a more recent focus than other studies.

Why were these cases chosen? First, Indonesia's foreign policy towards Iran's nuclear programme was chosen because (a) the issue generated considerable concern among Muslim groups in Indonesia and from members of parliament; (b) This issue was quite 
sensitive among Indonesian Muslims due to the involvement of the US and Israel. Worries that the US would attack Iran as it had Iraq increased the pressure on the Indonesian government; (c) The influence of Muslim groups as a moral force seemed substantial, pushing the government to shift its policy on the Iranian nuclear issue; (d) There was no vital national strategic interest that pushed the government to disregard Muslim groups' aspirations; (e) Muslim groups' aspirations were in line with the aspirations of the broader political constituencies. Therefore, it seems that Muslim groups were 'collaborating' with members of parliament; (f) there was a possibility of external pressure from the US and its allies opposing the Iranian nuclear programme.

Second, the case of Kosovo's independence was chosen because (a) the issue attracted the concern of Indonesian Muslim groups; (b) the issue has not been very sensitive among Indonesian Muslims; (c) despite intense pressure from Muslim groups, especially Muhammadiyah, their influence on Indonesia's willingness to acknowledge the independence of Kosovo has been relatively low; (d) there was a vital national strategic interest related to separatism or national territorial integrity that encouraged the Indonesian government to block Muslim groups' aspirations; (e) Muslim groups' aspirations are not in line with the aspirations of the broader political constituencies.

Third, Palestinian statehood was chosen because (a) this issue was quite sensitive among Indonesian Muslims due to the involvement of the US and Israel; (b) the influence of Muslim groups as a moral force appeared to offer substantial support to the government to take necessary initiatives to help the struggle of the Palestinian people; (c) there has been a 'common position' among the government, Muslim groups, and members of parliament on Palestinian statehood; (d) Muslim groups' aspirations are closely in line with the aspirations of the broader political constituencies; (f) there was no vital national strategic interest urging the government to disregard Muslim groups' aspirations. Despite this, support for Palestine is justified by the 1945 Constitution, which urges the abolition of colonialism (in Indonesia, Israel's occupation of Palestinian lands is commonly regarded as a form of colonialism).

\subsection{Data collection and analysis}

The author conducted field research in Indonesia for a period of six months from July 2013 to January 2014. This thesis used the following types of data as follows: 


\subsubsection{Primary and secondary written documents}

This research has utilised both primary documents such as unpublished documents from the Indonesian Ministry of Foreign Affairs and unpublished documents from Muslim organisations, as well as secondary documents consisting of books, articles, and other data from daily newspapers and magazines. Complementing secondary data, the author conducted field research in Indonesia to collect some materials, such as unpublished documents, which could not be accessed through the internet, and to conduct interviews.

\subsubsection{Interviews}

The author consulted 53 interviewees (see appendix) as key informants who can be divided into four categories. The first were foreign policy decision makers from the Ministry of Foreign Affairs and other related government agencies. The second were Muslim group leaders, including those from moderate groups such as Muhammadiyah and NU and also from militant Muslim groups such as Hizbut Tahrir Indonesia (HTI). The third were academics and scholars who are considered experts in Islamic politics and Indonesia's foreign policy. The fourth group comprised of politicians, especially those who have had concerns about Muslim issues. The politicians consisted of members of parliament and the leaders of Islamic political parties such as Partai Keadilan Sejahtera (Prosperous Justice Party) or PKS; Partai Persatuan Pembangunan (United Development Party) or PPP; Partai Amanat Nasional (National Mandate Party) or PAN; and Partai Kebangkitan Bangsa (National Awakening Party) or PKB. The interviewees also included former officials and former members of parliament such as Jusuf Kalla, Indonesian Vice President in the periods of 2004-2009 and 2014-2019 and Dr N. Hassan Wirajuda, Indonesian Foreign Minister in the periods of 2002-2004 and 2004-2009.

This research generally utilised a semi-structured interview format where questions were open-ended. Such questions consisted of opinions or value questions; feeling questions; and knowledge questions. The interviews in this regard were topical and evaluation interviews (Mayan, 2001). The interviewees were asked questions, among other topics, on (a) the influence of Muslim groups on foreign policy; (b) the response of the government to Muslim groups' aspirations; (c) the mechanisms Muslim groups use to channel their aspirations to the Indonesian parliament; and (d) the mechanisms Muslim groups use to lobby the government and vice versa. 


\section{Time limitation}

This thesis focuses on the democratic era in the post-Suharto period, and particularly on the presidency of Yudhoyono from 2004 to 2014, for the following reasons. First, in Yudhoyono's administration, Islam was openly regarded as an asset. His administration projected democracy and Islam as the two elements of soft power in Indonesian diplomacy (Sukma, 2011). Indonesia's foreign policy has also based itself around the country's identity as the world's largest Muslim country and the world's third largest democracy. Consequently, this phenomenon adds political leverage for Muslim groups to voice their foreign policy aspirations.

Second, the ascendancy of Yudhoyono to power marked the beginning of a consolidated democracy in Indonesia. Yudhoyono was elected through a direct presidential election in 2004. Prior to a 2002 amendment to the 1945 Constitution, the president and the vice president of Indonesia were elected by the country's highest body, the People's Consultative Assembly (MPR).

Third, in his two presidential terms-from 2004 to 2009 and from 2009 to 2014Yudhoyono formed his government with the support of all Islamic political parties including PPP, PKB, PAN and PKS in his government coalition. Therefore, it is assumed by many that Yudhoyono has taken into account the interests of Islamic political parties with regard to Muslim concerns (interview with Al Muzammil Yusuf, 26/11/2013).

\section{Thesis structure}

This thesis is divided into seven chapters. Following this literature review and background chapter, Chapter Two discusses the role of Islam in Indonesian domestic politics. This chapter also traces the role of Muslim groups in the colonialist era and their power struggle vis-à-vis the secular national movement in Indonesia's formative years. It addresses the role of Islam during the time of Sukarno and Suharto, the efforts of Muslims to deal with Suharto's harsh policy towards Islam, and Suharto's response to Muslims' attempts to create a 'Cultural Islam' movement. This section also investigates the way in which Suharto's Islamic policy and the Cultural Islam movement still influences Indonesian Muslim politics in the present day. It also examines the role played by Islamic political parties and Muslim groups in domestic politics during Indonesia's democratic era. 
Chapter Three investigates the extent to which Islam-as a political and moral forceinfluences Indonesian foreign policy. This chapter seeks to provide a snapshot of the role of Islam in Indonesia's post-Suharto foreign policy before moving on in subsequent chapters to discuss specific case studies. It begins by outlining the basic tenets of Indonesia's foreign policy and the state's interpretation of international issues of concern to Muslims in Indonesia. For example, it looks at how issues relating to the plight of the Muslim people in Kosovo and Palestine fit into the framework of the country's foreign policy. Also discussed is the influence of democratisation in Indonesian foreign policy including the government's response to Muslim groups' aspirations on international issues relevant to them. The necessity of restoring Indonesia's international image in the aftermath of the Bali bombings and the need to eliminate the world's misperception of the Muslim world including Indonesia have prompted the inclusion of Islam in the country's public diplomacy. Subsequently, this chapter also examines the projection of Indonesia's identity as the world's largest democratic Muslim country. This image has formed Indonesia's new international activism regarding Islam, which is intended to depict the country as a role model for other Muslim states with regard to the intersection of Islam, democracy and modernity.

Chapters Four to Six constitute the case studies which represent the main analytical body of the thesis. Chapter Four examines the government's policy towards the Iranian nuclear program when the country was a non permanent member of the UNSC in the period of 2007 to 2008. This chapter analyses the reasons the government changed its policy from initially supporting UNSC resolution 1747 to abstaining on UNSC resolution 1803. This chapter explores whether pressure from Muslim groups, which were buttressed by members of parliament, was a determining factor in shifting that policy. This also requires an investigation into the foreign policy decision making process which may have included pressures from major Western countries sponsoring resolutions against the Iranian nuclear programme.

Chapter Five reveals the Indonesian government's response to Muslim groups' aspirations towards the recognition of Kosovo's independence. The extent to which the government responded to Muslim concerns over Kosovo and debates between the Indonesian government and Muslim groups on that matter will be examined. Also investigated in this part is the reaction and position of the Indonesian government prior to and immediately 
following the declaration of Kosovo's independence. It will be revealed how the two opposite sides (the government of Indonesia and the proponents of the recognition of Kosovo's independence) used a concept of national interest to justify their respective arguments. To provide a broader perspective, the chapter also discusses other Muslim countries' reactions and positions with regard to Kosovo's independence, as there has not been a single response from the Muslim world.

Chapter Six looks at the Indonesian government's policy toward Palestinian statehood. This requires consideration of Indonesia's policy toward the Palestinian question under the Sukarno and Suharto regimes as well the administrations of the post-Suharto era. By doing so, the author intends to offer a comparative perspective on the regimes' policies on Palestinian statehood in the pre- and post-democratic era and to offer a general understanding of the impact of democratisation on the government's response to Muslim groups' aspirations on the Palestinian cause. As Palestinian statehood cannot be separated from discussions of Israel, Indonesia's policy of non-recognition toward Israel in the preand post-Suharto eras is also discussed. The chapter also treats as a sub-case the Gaza wars which allow description of the interplay between the Indonesian government and Muslim groups in a more specific context.

Finally, Chapter Seven brings together the overall discussion by presenting a general conclusion on the role of Islam in contemporary Indonesian foreign policy and providing more specific conclusions which arise from the three case studies. The drawing of these conclusions is based on empirical evidence regarding the interplay between the government of Indonesia and Muslim groups on international issues which have become of concern within significant parts of Muslim society. 


\section{CHAPTER TWO \\ ISLAM AND INDONESIAN DOMESTIC POLITICS}

\section{Introduction}

It is not easy to define the role of Islam in the national politics of a pluralistic country such as Indonesia although Islam is a majority religion in that country. As a religion which does not separate religion and politics, Islam has been used by some actors to support efforts to establish an Islamic state. The latter is perceived by its proponents to be the ideal foundation from which to enforce shariah law. The idea of an Islamic state in Indonesia has greatly contributed to uneasy relations between Muslim groups and the government of Indonesia. Islam was regarded as a threat by the regimes of Sukarno and Suharto.

Muslim views on Islam and politics are not monolithic. There are different interpretations ranging from legalism or formalism to substantialism. ${ }^{2}$ Islamic political vision was offered by Indonesia's founding fathers along with other ideologies in their search for what might constitute an ideal Indonesia (Effendy, 2003). The country eventually became known as the Pancasila state. However, in the years following Indonesian independence in 1945 , Muslims struggled to agree on what the ideal relationship was between Islam and politics. Their aspirations were channelled through political struggle. Political Islam, in reality, consistently failed to challenge the nationalist elements in the national political arena.

Both in the Sukarno and Suharto periods, Political Islam ${ }^{3}$ was discouraged and was even marginalised. The appearance of some Islamic extremist rebels in the Sukarno era who promoted Islamic symbols and elements precipitated constant suspicion towards Muslim groups. The demise of Masyumi, an Islamic political party in the 1960s, marked the marginalisation of political Islam in Indonesia's politics under Sukarno's 'Guided Democracy' and in the Suharto period. The situation changed after Suharto stepped down from power in 1998. Muslims and other elements of society enthusiastically responded to the coming of the democratic era by establishing political parties. Religious and non-

\footnotetext{
${ }^{2}$ Substantialism refers to a perspective viewing the conclusiveness and integrativeness of Islam and opposing legalistic and formalistic expressions of Islam. Substantialism denies the "symbolic and ideological issues of political Islam" and stresses the importance of the substance of content of Islamic teachings (Bush, 2009, p. 12; Effendy, 2003).

${ }^{3}$ Political Islam here is intended as a common name referring to political movements that use Islam to gain power through competitive elections and work within the existing political system (Lee, 2004, p. 87).
} 
religious parties including Islamic political parties were established at that time. Some Islamic political parties used Islam as their foundation and others organised themselves around Pancasila. This chapter investigates the place of Islam in domestic politics and examines the extent to which Islam has influenced Indonesia's political life. This chapter argues that Muslim groups have shown an increasing influence in domestic politics despite their electoral defeat in several general elections in the post-Suharto era. The detailed discussion on the interplay between Muslim groups and the government in the pre- and post-Suharto eras will be approached using Skidmore and Hudson's statist-pluralist perspective which covers the interactions of state and society in both authoritarian and democratic regimes.

This chapter starts by addressing power struggles among Muslims in the formative years of an independent Indonesia. It then discusses the place of Islam during the time of Sukarno and Suharto, the efforts of Muslims to deal with Suharto's harsh policy towards Islam, and Suharto's response to Muslims' attempts to create a Cultural Islam movement. Finally, it examines the way in which Suharto's Islamic policy and the Cultural Islam movement still influence Indonesian Muslim politics to the present day.

\section{The Dutch policy on Islam and the emergence of a Muslim nationalist movement}

Islam had an uneasy relationship with the state during much of the Dutch colonial era. Islam had developed as a source of opposition against Dutch colonial forces (Ali, 2013; Houben, 2003). For the Dutch, Muslims were regarded as a 'political danger' to colonial interests (Jung, 2010, p. 289). The Christianisation of the Dutch East Indies' population was supported by the Dutch government to realise its colonial goals (Goksoy, 2002; Noer, 1978; Pearson, 1990) and to impede the influence of Islam (Benda, 1958). However, compared to the Portuguese and Spanish colonial powers, the Dutch did not collaborate so closely with missionaries (Benda, 1958).

Aside from being a source of opposition to Dutch rule, Islam was emphasised as a source of Indonesian nationalism. There was a strong belief among Indonesian people that the colonialists not only exploited their natural resources but also fought against their faith. Although such disputes were the result of arbitrary policies toward people and were mainly not connected with religious matters, popular revolts against colonialists were frequently 
regarded as holy wars and positioned the colonialists as infidels. Popular mobilisation proved effective when using religion as a means to revolt against the colonial regime. Islamic sentiment also stirred up nationalism and anti-colonial sentiment (Sumanto, 2012, p. 30). Islam was one of the common factors in Indonesian life during the colonial era. It managed to bridge differences among various ethnicities and broke the partitions of localism. As Vandebosch (1952) wrote, "it is doubtful whether the propaganda for an Indonesian nationalism could have been successful without the activity of the religious elements" (p. 182).

The Dutch policy towards Islam changed significantly after the appointment of Christian Snouck Hurgronje (1857-1936), an outstanding Leiden scholar, as an Advisor on Arabian and Native Affairs in the Netherland East India in 1889 (Benda, 1958; Jung, 2010). Islam as religion seemed to be separated from politics, and in this period Islam was considered to be dangerous when it was involved in political activities (Benda, 1958). Religiously mobilised anti-colonial activities and Pan-Islamism agitations were not tolerated. To this end, the government empowered the aristocracy, local rulers, and local customs and traditions to fight against the political potential of Islam (Jung, 2010).

Snouck's views, which materialised through a policy toward Islam, reflected the Dutch political ethical policy ${ }^{4}$ more generally. These policies aimed to provide more opportunities for people of the colony to better their lives. By doing so it was hoped that integration between the colony and the Dutch motherland would improve. However, the policy failed. Instead of creating a sense of attachment to the Dutch motherland among the colony's younger generation, the modern education system built by Snouck Hurgronje helped give rise to the nationalist movement (Jung, 2010).

Indonesia's nationalist movement attempted to find a national identity and to provide an alternative to colonialism. There were two main parts to the Indonesian nationalist movement. The first had its roots in the Javanese aristocracy and the Western educational values of Budi Utomo (Noble Endeavour). Established in 1905, this organisation aimed to promote the establishment of schools for Indonesians and the revival of pre-Islamic

\footnotetext{
${ }^{4}$ The ethical policy was "formulated to serve the interests and well-being of the indigenous people of the Dutch East Indies" (Bloembergen, 2006, p. 224).
} 
culture. The second group was commonly associated with Sarekat Islam (Association of Islam) which used Islamic symbolism in a struggle against Dutch colonialism. As a consequence of the two groups, various social and political organisations emerged, striving for the independence of Indonesia (Syamsuddin, 1991).

While Budi Utomo constituted a local organisation with its membership dominated by Javanese aristocracy, the first supra-regional mass movement in modern Indonesia was Sarekat Dagang Islam (Muslim Trading Association) or SDI which was established in 1911. The movement then renamed itself Sarekat Islam (Association of Islam) or SI in 1912 with H.O.S Tjokroaminoto as its prominent leader. As it began to identify itself as political party, the movement embraced an Islamic-socialist ideology with an Islamic modernist character by stressing rationality in understanding Islamic teachings and doctrines and eliminating the syncretised religion (Abdullah, 2009). The socialist ideology of SI envisioned the realisation of social justice in society which placed Islam as the basis of social values (Nasihin, 2012). Besides the kind of modernist Islamic thinking embraced by Agus Salim, which emphasised worship aspects, there was some indication that the movement was also influenced by Pan Islamism, which was ascribed to Egyptian thinker Jamaluddin al Afghani (Prins, 1959; Reid, 1967).

SI can also be called an Islamist-nationalist movement as it demanded greater political independence for Indonesia. SI's leaders such as Tjokroaminoto and Agus Salim have also been widely recognised as among the most prominent national leaders in the fight against colonialism. Therefore it is not surprising when we find the terms 'Muslim nationalist' and 'secular nationalist' in the discussion of Indonesian history. Tjokroaminoto greatly influenced Indonesian secular nationalist leaders like Sukarno and others. As Korver (1988) has written, "in his autobiographical memoirs, Sukarno referred to Tjokroaminoto as his mirror and his first model in the arts of oratory and political leadership" (p. 21)

However, this movement began to decline in the mid 1920s due to a split leadership and increased vigilance from the government. The movement's efforts to exert a political role by renaming itself Partai Serikat Islam (Islamic Association Party) in 1923 and further becoming Partai Sarekat Islam Indonesia (Indonesian Islamic Association Party) in 1930 achieved little success. At that point in time, the national leadership in search of independence was overtaken by secular nationalist leaders Sukarno, Hatta, and Sutan 
Sjahrir (Benda, 1977). But there were no Islamic political movements dominating the Indonesian political sphere until the occupation of Japan in the early 1940s.

As SI had been involved more deeply in the political struggle, the religious and social initiatives were handled by Muhammadiyah (Abdullah, 2009). Founded by Kyai Haji Achmad Dahlan in Yogyakarta in 1912, Muhammadiyah avoided direct involvement in politics and focused more on economic, social, cultural (education) and religious activities. This organisation played an important role in pre and post-Indonesian independence politics. As a reformist and modernist religious movement, Muhammadiyah was concerned about efforts to purify Islamic teachings that were not based on Al-Quran and hadits, including innovations in shariah (bid'ah); syncretism; and local traditions (Benda, 1977). Pragmatically, this movement adopted the methods of Christianisation although its establishment was believed to be an effort to curb Christianisation. It also adopted a Western education system and added Islamic content to it. Therefore, this movement was open and had significant cooperation with other Muslim groups (Federspiel, 1970; Muhammadiyah, 2010).

Aside from the emergence of modernist movements like Sarekat Islam, Muhammadiyah, Jamiyat al-Islah wal-Irsyad in 1914 (Jonge, 1993) and Persatuan Islam (Islamic Union) in 1923 (Federspiel, 2001), the Dutch colonial era also witnessed the establishment of traditionalist movements like Persatuan Tarbiyah Islamiyah (Islamic Education Union) in 1930 and NU in 1926. NU was founded by KH. Hasyim Asyari in Surabaya to voice the interests of traditional Islam, especially the pesantren (Islamic boarding school) system. The modernist movements in the Muslim world posed a kind of threat to traditionalist Muslims (Bush, 2009). The emergence of modernist organisations in Indonesia and the take over of Mecca and Medina by the Wahabi movement prompted NU to come into existence (Marjani, 2012). These groups closely follow a variety of traditional customs, values, and practices (Mehden, 2008). In $1933 \mathrm{NU}$ had 40,000 members and continued expanding its organisational wings for youth, women, education and cooperatives. By 1938 its membership had reached 100,000 people with 99 organisational branches (Barton \& Fealy, 1996).

Despite their differences, both modernist and traditionalist movements were united for the sake of Indonesian independence. Both supported the creation of the Gabungan Politik 
Indonesia (Indonesian Political Association) in 1934 and Majelis Islam A'la Indonesia (Indonesian Muslim Supreme Council) or MIAI in 1937 and the call for the formation of Majelis Rakyat Indonensia (Indonesian People's Council) in 1939.

\section{The power struggle between secular nationalists and Muslim nationalists}

The two mainstreams of the nationalist movement-namely the secular nationalist movement and the Muslim nationalist movement-worked together to fight against colonialism yet competed against each other immediately before the independence of Indonesia. The future conception of a new state of Indonesia served as a driving force for further competition between the two main parts of the nationalist movement.

The most important encounter between the secular and Muslim nationalists happened at the meeting of Badan Usaha Persiapan Kemerdekaan Indonesia (the Inquiry Committee for the Preparation of Indonesian Independence or BPUPKI) in June 1945, which aimed to debate the forthcoming state's philosophical foundation and constitution. The debate reflected dichotomous political aspirations within Indonesian society between those wanting an Islamic state of Indonesia and those who were willing to have a secular one. The Muslim nationalists supported the proposal for Islam to be the basis of the state. Meanwhile the secular groups proposed Pancasila (five principles) as the state's basis. Those five principles were nationalism, humanitarian/internationalism, mutual deliberation, social welfare, and Belief in God (Boland, 1971, pp. 20-23). The first group comprised Muslims of various traditionalist and modernist Muslim organisations and the second group consisted of Muslims from various secular organisations and a few nonMuslims (Syamsuddin, 1991).

A compromise was reached after an agreement to formulate seven words known as the Piagam Jakarta - Jakarta Charter. The charter aimed to become the preamble of the state constitution in which Pancasila had earlier been approved as the basis of the state. The Jakarta Charter was vital as it required the state should be based on 'Belief in God', followed by 'seven controversial words', namely: “dengan kewajiban menjalankan Syariat Islam bagi pemeluk-pemeluknya" (with the obligation to carry out Islamic shariah for its adherents) (Boland, 1971; Hilmy, 2010, p. 73). These seven words of the Jakarta Charter have always coloured discussions on Islam-state relations in Indonesia. 
The political compromise seemed fragile and was abrogated a few months later, one day after Indonesia's independence and just moments before the constitution was adopted. The repeal came after a Japanese Navy officer's report to Hatta that Christians residing in Indonesia's eastern parts would secede if the Jakarta Charter was pursued. In fact Christians realised that the Jakarta Charter's adoption would not create any threats to their life. However, they thought such constitutional elements reflected discrimination (Hilmy, 2010). The deletion of the seven words of the Jakarta Charter was possible due to the tolerance and understanding of nationalist Muslim groups who had a strong commitment towards national unity which surpassed their religious beliefs. Another argument holds that nationalist Muslims' positive response to the final decision was because Muslim groups were optimistic they could win the next general election, which would be held within six months. The proposal to establish an Islamic state would be easily adopted when they won at the polls. However, the general election was not held until 1955, and Muslim nationalists were not well represented in the Committee on the Preparation for the Indonesian Independence (PPKI) despite their significant role in the pre-independence period. Moreover, their representatives were old men who advanced wisdom rather than political gain (Syamsuddin, 1991). These factors may have influenced the nuance of the meetings with regard to the establishment of a new state of Indonesia and the acceptance of Muslim nationalist groups on the final decision abrogating the Jakarta Charter.

The power struggle between secular and Muslim nationalists continued in the postindependence period, marked by the establishment of Partai Nasional Indonesia (Indonesian National Party) in August 1945 and Partai Masyumi in November 1945. Masyumi's membership comprised individual members and also included NU, Muhammadiyah, and some regional organisations in West Java as its extraordinary members (Boland, 1971, p. 41). However, the aim to make Masyumi an Islamic unifier failed due to internal conflict. As a result, NU withdrew from Masyumi in April 1952 and converted into a political party (Boland, 1971). Aside from PNI, the challenge to Masyumi came from Partai Komunis Indonesian (PKI), the Indonesian Communist Party - a longtime foe of Muslim nationalists in the pre-independence period.

The configuration of the three political forces of Islam, secular nationalism, and communism was shown in the result of the 1955 election, in which there was no dominant political party. The PNI gained the largest share of votes in the election $(22.3 \%)$, followed 
by Masyumi (20.9\%), NU (18. 4\%), and the PKI (16.4\%). Other Islamic parties, namely the PSII and Partai Tarbiyah Islam Indonesia (Indonesian Islamic Education Party) got only $2.9 \%$ and $1.3 \%$ respectively. All together, the Islamic parties won $43.5 \%$ of total vote (Boland, 1971; Liddle, 1996). The disunity of Islamic parties that led to their defeat was possible due to their political praxis interests and their differing modernist and traditionalist religious backgrounds.

Tensions among Islamic parties, especially between Masyumi and NU, ocurred with regard to governmental position issues i.e. power sharing in the cabinet. In the aftermath of election, the second cabinet of Ali Sastroamijoyo - which included the PNI, Masyumi, and NU_was forged in March 1956. The resignation of Mohammad Hatta as Vice President due to his disagreement with Sukarno's idea of 'Guided Democracy' sparked protests from his sympathisers and supporters, particularly those from islands outside Java, further strengthening anti-Jakarta and anti-Sukarno sentiment. Masyumi, whose constituents were mainly from islands outside of Java, joined in on the protests. Consequently, Masyumi withdrew from the cabinet, while NU continued to hold its seats. This intensified the tensions between Masyumi and NU (Boland, 1971, p. 87).

Despite their differences and tensions, NU and Masyumi-along with other Islamic parties - worked in tandem to push for the return of the 'seven words' of the Jakarta Charter to the Constitution Preamble. At the Constituent Assembly meetings (1957-1959), tasked with making a new state constitution, Islamic parties formed an Islamic bloc and confronted PNI and other non-Islamic parties (Boland, 1971). The confrontation ended with the dismissal of the Constituent Assembly by Sukarno after which, in mid-1959, he began to reinforce the 1945 Constitution, marking the beginning of 'Guided Democracy' (Lev, 1966, p. 277).

\section{The suppression of political Islam}

Indonesia under the secular nationalism of Sukarno and Suharto did not offer any chance for the establishment of an Islamic state. Both Sukarno and Suharto enforced strict controls on political parties. Muslim groups were suppressed and oppressed. The suspicion that Muslim groups had always aspired constitutionally or unconstitutionally to an Islamic state was paramount among the government and military (Carnegie, 2008). 
The political realm in the Sukarno era was dominated by Sukarno (nationalists), Islam, the Army, and PKI. Muslim groups, especially Islamic political parties, faced confrontation with the rest of those powers. The suppression of Muslim groups was demonstrated by Sukarno when he banned Masyumi in 1960 as its leaders were involved in the Perjuangan Rakyat Semesta (Struggle of the Universe's people) or PRRI in West Sumatera and Manado in 1958. In fact, the uprising did not solely involve Muslim elements but also Christian, ethnic and other groups (Liddle, 1992; Vlekke, 1959). Masyumi's refusal to condemn those who were involved in the PRR (Feith, 1962) might also have been a trigger for the ban. As time passed, Sukarno increasingly showed his power by dissolving all but ten parties in April 1961 (Feith, 1962). With the exception of Masyumi, the rest of the Islamic parties (NU, Perti, and PSII) survived the harsh policy.

Among the Islamic parties, only NU cooperated with the regime in areas such as the formation of the cabinet. NU cooperated with Sukarno throughout the Guided Democracy period (Federspiel, 1973). While ideologically and historically against communism, NU wished to cooperate with the Indonesian Communist Party (PKI) under the imposed ideological slogan of the Nasionalis-Agama-Komunis (Nationalist-Religious-Communist) or Nasakom which was created by Sukarno. Therefore Lev (1967) has referred to NU's "uncertain political principles" (p. 55). Lev's argument sees NU as opportunistic. Fealy (2003) and Marjani (2012) disagree with such a view. Fealy argues that NU's political attitude in the period of 1952-1967 was the combination of accommodative and militant attitudes depending on the political context and situation. Meanwhile Marjani prefers to call it a tolerant attitude for the greater benefit of Muslim society. In the introduction to their edited book on NU (1996), Barton and Fealy (1996) contend that NU in the Sukarno period was known to have "political flexibility and accommodation" (p. xx). According to Fealy (2003), NU's approach was not as opportunistic as many think. In fact, NU was consistent in its political religious stance which had been embraced for a long period. NU's political ideology is based on Sunni Islamic jurisprudence which prioritises the protection and the benefits of Islam and its adherents.

Despite Islam being regarded as a threat to the state, the army-especially those members of a modernist secular persuasion such as General Abdul Haris Nasution-had cordial relations with Islamic groups in order to promote religious activities (Federspiel, 1973). Besides the reflection of their religious awareness, their close relations with Islam might 
also have been aimed at countering the communists who grew stronger everyday under the protection of Sukarno. According to Lev (1966, p. 278), Nasution himself was regarded by Sukarno as a rival to his power. Tensions between Sukarno and army leaders occurred frequently regarding the PKI. Consequently, Sukarno endeavoured to set out the power balance between army and other groups, to break up officer corps, and to weaken Nasution's power even though he was not so ambitious as to challenge Sukarno for the presidency. With regard to the relationship between Islam and the army, Federspiel (1973) contends that Nasution's group wished for the promulgation of "doctrinaire Muslim religious beliefs and ritual among armed services personnel as a means of assuring a common ethical and moral guide and standard of behaviour" (p. 410). Nasution's group utilised available instruments such as imam militer (the military chaplain service), regular Islamic commemoration days, and the issuance of religious books to realise its goals. However, their activities were mainly related to religious rituals and ceremonies and they shunned politically oriented activities.

Muslim groups continued to experience unpleasant situations with regard to Islam-state relations for at least the first 20 years of Suharto's rule (Hefner, 2000; Liddle, 1996). The role of Muslim groups was systematically diminished, and they had only a marginal place in the national political arena. Muslim politicians faced discrimination, persecution, and arrests. Suspected Muslim militants were excluded from the national bureaucracy and political activities. Islamic politics were labelled as right wing elements and treated as 'a threat and public enemy'. Islam was ranked as the second most dangerous challenge after the leftist extreme: the communists who were responsible for the 1965 revolt (Liddle, 1996).

The change of regime from Sukarno to Suharto brought new hope for a better situation for Muslim groups. They expected to be able to forge a better relationship with the government and the army given that Muslim groups had played a pivotal role in bringing down the Indonesian communists in 1965. However, once again the new regime disappointed them as it refused to lift the ban on the Masyumi party. Instead, Suharto allowed the establishment of Partai Muslimin Indonesian (Indonesian Muslim Party) in April 1967 (Samson, 1968). The seeds of Suharto's authoritarianism had been clear since the beginning of his accession to power. The regime considerably intervened in and controlled the Parmusi party (Porter, 2002). The government attempted to cut Parmusi's 
ties from Masyumi's legacy and spirit. Consequently, Parmusi lost the spirit of struggle it had inherited from Masyumi.

On the other hand, a number of NU members had been forced to join the Golkar and its affiliated organisations which were to become Suharto's political machinery. Due to the manipulation and intervention of the government regarding Parmusi, Muhammadiyah dissociated itself from Masyumi and halted its support to Parmusi. This marked the withdrawal of Muhammadiyah from the political arena. Meanwhile, Parmusi collaborated with Golkar against NU and the PNI during the 1971 election campaign. This contributed further to the disunity of the political Muslim groups and dispersed their influence (Porter, 2002). The result of systematic efforts of the government to control political life was seen throughout the 1971 election. Golkar seized 227 out of 360 allocated seats, while NU and the Parmusi gained 58 and 24 seats respectively (Samson, 1971). Of the total votes, Golkar reaped 62.8\%, NU took 18.67\%, and Parmusi 5.4\% (Porter, 2002).

Politically defeated, Muslim groups were often the subject of suspicion, marginalisation or even suppression (Effendy, 2003). This situation was worsened by the common perception that Islam was synonymous with rebellion and opposing the central government in the preand post-independence periods. The spectre of the Darul Islam fundamentalist revolt in 1949 and the rising PRRI in 1958 led to the continuous suspicion and suppression of Muslim groups in this era. The arguments given for the suppression and suspicion of religious politics focused on the need for national unity and political stability (Vatikiotis, 1998). As in the Sukarno regime, Suharto stopped Islamic elements from becoming important players in Indonesian politics. Suharto's dual policy on Islam, according to Effendy (2003), seemed to emulate the Dutch colonial policy, namely preventing Islam from politics and at the same time promoting its religious rituals. Islam was confined to worship.

In an effort to erode the link between aliran (stream) ${ }^{5}$ and the political behaviour of the people, the regime promoted Pancasila as the sole ideology for political and mass

\footnotetext{
${ }^{5}$ The santri (pious Muslim)-abangan (nominal Muslim) approach-which had been influenced by work of Geertz (1960) - has been frequently used to explain Indonesian politics especially in the eras of Sukarno and Suharto. It has been useful to look at "politik aliran" or "political stream" which was clearly reflected in the first democratic election in 1955. Aliran which literally translates as stream or current is used in the Indonesian political context as "any group characterized by adherence to similar ideas or ideals" such as aliran agama (religious stream) and aliran nationalis (nationalist stream). The 1955 election result shows the
} 
organisations. The de-politicisation strategy that was also known as de-ideologization or Pancalization, drew heavily from the thought of a key New Order strategist, Ali Murtopo-a Muslim but one hostile to Muslim groups (Ramage, 1995, p. 186). This was an indiscriminate strategy, though it was an open secret that it was actually directed at the Muslim community. Indeed, Suharto utilised all possible means to secure his power, including making Pancasila the ideological legitimisation of his regime (Ramage, 1995). He controlled most aspects of Indonesian life. Suharto, as described by Ricklefs (2012), directed his people in not only how to act, but also how to think and feel. Therefore, only the regime had the authority to interpret Pancasila, which was consequently utilised as a means to guard the interests of the regime. The regime was accused of abusing the interpretation of Pancasila, which was often used to suppress its political enemies, especially Muslim groups.

The implementation of this de-politicisation strategy reached its peak in 1985 with the adoption of a law requiring all mass-based organisations to accept Pancasila as their sole philosophical basis. This law was initially proposed in 1982. After deliberation of the bill in parliament, strong protests were sparked on many sides, especially among Muslim organisations. Sjafruddin Prawiranegara, a former leader of Masyumi sent an open letter to Suharto in July 1983 accusing the government of using the bill as an instrument to control Islamic organisations. Indeed, politically-oriented Islam was the main target of the depoliticisation program (Porter, 2002, p. 41). The regime insisted on its plan arguing that Pancasila should be accepted without conditionality as it was critical for maintaining national unity and stability (Ramage, 1995, p. 35). This obstinate initiative of Suharto's led to a riot at Tanjung Priok, North Jakarta, in September 1984. Unarmed Muslims faced off with the military, leading to the death of dozens-according to the military-and hundreds - according to Abdurrahman Wahid — of innocent protesters (Raillon, 1993, pp. 197-200; Ramage, 1995, p. 19).

The decision to impose Pancasila as the sole foundation for political and mass organisations was a way to control their political aspirations. This movement had started in the very early years of Suharto's administration. Through Law no. 3/1973, the government forced the fusion of nine political parties into two parties. PNI and other nationalist parties

reality of four more aliran politik (political streams) (Cribb, 1992, pp. 11-12). The categorization of aliran is useful, though problematic due to blurred borders between one stream and the other. 
as well as the Christian parties transformed themselves into the Partai Demokrasi Indonesia (Indonesian Democratic Party) or PDI, while the Islamic parties (NU, PSII, and Parmusi) fused to become Partai Pembangunan Indonesia (Indonesian Development Party) or PPP (Liong, 1988; Sabri, 2012). The PPP's name was intentionally chosen by the government to dissociate the party with any Islamic character. However, the government failed to prohibit PPP from using Ka'bah (the cube-shaped architecture at the centre of the Haram mosque in Mecca) as its electoral symbol after the PPP threatened to withdraw from the 1977 election if it was forced to do so (Liong, 1988). However PPP changed its party's symbol of 'Ka'bah' with 'Star' when Pancasila was enforced for all political parties and mass organisations as the force majeure in 1984 (Weatherbee, 1984). From that time until the end of the New Order, the electoral vote was contested by Golkar, PDI, and PPP. Until the fall of Suharto, this helped Golkar to secure a landslide victory in every general election (Sabri, 2012).

\section{Cultural Islam and Muslims' political rapprochement with Suharto}

In response to the political pressure on Muslim groups, their leaders were divided into two-but not limited to two-major camps. The first group comprised young Muslim activists and intellectuals, while the other consisted of most senior leadership of the Masyumi party which had been banned by Sukarno in the 1960s. Despite their agreement on the wisdom of using dakwah (religious proselytisation) as their approach to face the government's harsh policy towards Muslims, both camps disagreed on long-term political goals (Hefner, 2001). While the latter still aspired to the establishment of an Islamic state, the former emphasised that the most imperative goal was to colour the state with Islamic principles such as a respect for pluralism, tolerance, and to advance good governance, protection of the weak and achieve social justice. The promotion of Islamic values was not to be imposed through the state but via Muslims' hearts and minds by encouraging their religious awareness. Such a movement is commonly known as the Cultural Islam movement. The Cultural Islam movement did not come in a single coherent form. Instead, it reflected various manifestations which had a shared aspiration for the transformation and revitalisation of Indonesian Islam as well as the avoidance of a destructive confrontation with the Suharto regime (Fealy, Hooker, \& White, 2006).

To some extent this movement fitted the de-politicisation strategy that the Suharto regime employed to curb formal political Islam. The Cultural Islam movement emerged 
concurrently with the regime's hardest pressure towards politically motivated activities in the 1970s and 1980s (Fealy et al., 2006). Indeed, it is safe to say that while discouraging political Islam, Suharto promoted religious rituals and worship. These circumstances paved the way for the development of the Cultural Islam movement. The movement has had a great influence on Muslims' perceptions of the relationship between Islam and the state. The Cultural Islam movement sought to promote Muslim aspirations through social, educational, intellectual, and other cultural aspects and shunned any kind of formal politics (Ricklefs, 2012, p. 48).

Most proponents of this movement came from the modernist and traditionalist intellectual camps. Among the movements' prominent figures were Nurcholis Madjid, an outstanding Islamic thinker and philosopher, Abdurrahman Wahid, a Muslim intellectual and pluralist adherent who would later become President of Indonesia, Johan Effendi and Dawam Raharjo — both intellectuals_-and Kuntowidjoyo, an intellectual and humanist.

Nurcholis Madjid's concept of desacralization urged for the freedom of mankind to regard profane matters as if these matters were transcendental. As Al-Quran does not provide a detailed conduct for life, questioning the state, party and ideology are not something sacred (Weck et al., 2011). Subsequently, in order to shift the movement away from political Islam, Madjid came up with his remarkable slogan of 'Islam Yes, Islamic party No'. The future of Indonesian Islam, according to Madjid, would rest on culture, intellectualism, and education - and not on politics. Islamic parties would be counterproductive to the authoritarian regime. Any counter attack on the regime's secularising tendencies would further affirm its view of Islam as a threat, and such a situation would not bring any benefit to Muslims. Nurcholis' view shocked those proponents of a formal Islamic state whose belief was that Islam and the state are inseparable (Fealy, 2007a).

Meanwhile, Abdurrahman Wahid was a religious nationalist and proponent of a secular state (Mujani \& Liddle, 2009). Wahid believed the struggle for an Islamic cause could take any form so long as it did not contradict Islamic principles. He came up with the concept of the indigenisation of Islam (pribumisasi Islam), based on distinctive Indonesian features. He argued that the necessity of local situations should be taken into account when interpreting and understanding Islamic teachings, rather than separating Islam from its local cultural context by maintaining Islam in its original form. Therefore any effort to 
promote Islam as the only determining source of life would potentially be divisive given the heterogeneity of popular customs in Indonesia. Yet the right of Islam to colour aspects of life in Indonesia is the same as held by other religions (Weck et al., 2011). Together with Kyai Haji (KH) Ahmad Shidiq, Abdurrahman Wahid was an architect of NU's acceptance of Pancasila as the sole foundation of the Indonesian state in 1984 (Effendy, 2003, p. 132). After the NU national congress accepted Pancasila in 1984, Wahid stated that it was "only after clarifying that Pancasila should not be treated as a religion in the life of the nation nor be made to contradict religion that the congress was able to adopt the state ideology as its sole basis" (Wahid, 1996, p. xiv).

Wahid's initiative and efforts contributed to NU's declaration on the finality of Pancasila as the state ideology. According to Wahid, NU's withdrawal from practical politics would open wider opportunities as NU's cadres could join any parties including nationalistoriented parties. Subsequently, since the mid-1980s, NU has focused on social, economic and religious issues as well as political transformation programs (Effendy, 2003). Through its program on various socio-economic and religious issues, Muhammadiyah also rejuvenated the tajdid (renewal) of Islamic teaching that enabled it to cope with new challenges and to deal with the country's main problems in social justice and poverty. Both NU and Muhammadiyah are committed to promoting good governance in accordance with their status as a moral force.

Wahid developed NU into a more progressive organisation and frequently opposed Suharto. NU's withdrawal from politics had major implications. It allowed its members to vote for any political party, not just the PPP. According to Effendy (2003), NU's step reflected the general movement of the Islamic political dynamic, putting stress more on substance rather than form.

The second camp (Muslim modernist political leaders such as Natsir and other Masyumi figures who still aspired to the establishment of an Islamic state as their long term goal), turned their political activities into dakwah (Islamic proselytisation). This happened in the aftermath of the refusal of Suharto's regime to restore the Masyumi party. Natsir established Dewan Dakwah Islamiyah Indonesia (Indonesian Islamic Da'wah Council) or DDII in 1967. DDII's mission was to promulgate Islamic teachings to society. Rather than imposing Islamic teachings from above (the state), he preferred to do it from below, within 
society (Ricklefs, 2012). Like his junior intellectuals, Natsir realised that the new order regime was too strong to confront. In this context, the modernist DDII buttressed the government's dakwah agenda which was intended mainly to prevent a communist revival. Both DDII and the government had the same objectives and end goal, namely a deeper but non-political Islamisation (Ricklefs, 2012) or rather 'santrinisasi' (a process to call nominal Muslims to be pious Muslims).

Besides having been influenced by a global phenomenon of the Islamic resurgence, Suharto's policies seeking to undermine political Islam had also contributed to the emergence of more exclusive dakwahis movements in the 1980s, which were commonly called the 'Tarbiyah movement'. This movement initially grew in the Salman mosque at Bandung's Institute of Technology. The movement then inspired others and spread to more campuses. This movement, with its secretive teaching and discussion, was known as usroh (nuclear family). The term 'usroh' is also used in the Muslim Brotherhood (Ikhwanul Muslim) in Egypt (Bruinessen, 2002).

Such movements take the form of study circles (halaqah) that are established at mosques' campuses. The teaching methods offer more literal interpretations of Al-Quran and Al Hadits, claiming that their teachings are in accordance with the teaching of the Prophet and his early companions (Salafush shalih). Because they do not give 'text multiinterpretation' and tend towards 'exactness', such movements usually attract followers from 'methodologically similar' faculties such as the Faculty of Math and Natural Sciences. Such movements offered favourable environments for Middle-Eastern religious and political movements such as Hizbut Tahrir, Ikhwanul Muslimin, and Salafi-Wahabism to grow locally. Some movements preferred to operate clandestinely, especially those with political motives. As explained by Hairgrove and Mcleod (2008), Hizbut Tahrir, for example, chose to remain secret and have no name until it gained the confidence to become a mass organisation. This opportunity arose when Suharto's regime fell in the late 1990s.

There were many other hardline movements similar to Hizbut Tahrir which grew secretly during the Suharto period. They recruited their cadres and ran their movements underground. They were politically motivated groups. Such movements include the Darul Islam (Islamic State) movement, Jamaah Islamiyah, and other similar groups. All wish to 
establish an Islamic state based on their own distinct interpretation. Yet such movements have no political leverage in the real political arena as they have only a small number of followers and their radical ideologies do not attract people to join them. Morever, some groups of this kind remain clandestine.

Compared to Tarbiyah and other conservative modernist movements such as DDII, Cultural Islam belongs to the substantialist moderate movement (the first camp) and has attracted more followers. The moderate movement is usually called the 'Islam mainstream' or 'mainstream Islam'. Mainstream Islam is widely understood as an Islamic model that is associated with NU and Muhammadiyah. The Cultural Islam movement contributed to warm relations between Islam and the state. The suspicion of Islam began to diminish, leading to a change of political policy concerning Islam in the Suharto era. This involved a long process of dialogue regarding state-Islam relations.

As a part of the dakwah movement, Muslim groups vigorously promoted both educational programs at the grass roots level and empowerment in society: initiatives which were intended to help Muslim society find balance with the state (Hefner, 2000). The Islamic resurgence in the 1970s and 1980s was concurrent with Suharto's policy restricting Muslim activities to the non-political arena. This policy had "unwittingly contributed to the resurgence of Islam" (Hefner, 2000, p. 18). There was a significant increase in religious activities, the number of mosques, the number of Friday prayer attendees, the number of religious schools and their attendees, and other activities that led to the increase of the Islamic piety of society (Freedman, 2009). There was also an Islamic influence which had been visible in the commercialisation of products using Islamic symbols and motifs (Riddell, 2002). Although dakwah (which was also initiated by more conservative modernist Muslim groups) had coloured the character of Islam in Indonesia, the outcome of the Islamic resurgence was more complicated than "a simple shift from secular nationalism to conservative Islam" (Hefner, 2000, p. 18). Hefner believes that the increasing interest in sufism and the existence of the NU-Muhammadiyah combination as the bulwark of moderate Islam could 'save' the country from the control of conservative and radical Islam (Hefner, 2000). Aside from their role maintaining the character of moderate Islam in Indonesia, NU and Muhammadiyah as well as other Muslim groups managed to effectively influence state policy in domestic affairs (Freedman, 2009). As a result, in the 1990s, Suharto took a different approach towards Islam. His government, to 
some extent, accommodated the political aspirations of Islam. Muslims were given more places in politics without being suspected of being proponents of an Islamic state (Weiss, 2010).

The government endorsed numerous policies favouring Muslim groups, including: (a) Law No. 1 of 1974 on the the validity of marriage-based religion, especially Islam, (b) Law No. 7 of 1989 on religious courts, which were granted the right to manage exclusively specific civil matters of Muslims, (c) Law No. 1 of 1999 on Islamic Law Compilation, (d) Law No. 7 of 1992 on Banking which was amended by Law No. 10 of 1998 which requires conventional banks to open branches which operate on shariah principles (Weck et al., 2011). Despite regulating banking in general and without mentioning shariah banking, Law No. 7 of 1992 started to mention the concept of profit sharing principle (mudharabah) which has been commonly used in shariah banking. This term was further explained in the government decree No. 72/1992 on Banking which also discussed financing based on profit sharing in line with shariah principles (Al-Hakim, 2013).

In response to demands from various Muslim organisations and leaders, the administration of Suharto set in motion a number of other policies and actions: (a) Allowing female students in state schools to wear jilbab (veil); (b) Discontinuing a national sports lottery; (c) Sentencing a Catholic editor of Popular magazine who was found guilty of insulting the Prophet Muhammad; (d) Suharto's pilgrimage to Mecca in 1991; and (e) the establishment of the Indonesian Muslim Intellectual Association (ICMI) in 1991 (Liddle, 1996; Tirtosudarmo, 1992b).

There are several explanations as to why political attitudes towards Islam changed in the last period of Suharto's rule. First, Suharto needed to broaden his political base as he gradually lost the military's support, in particular the support of General Murdani's wing. He endeavoured to build alliances beyond his traditionally staunch allies including the military and the Golkar ruling party (Sukma \& Joewono, 2007). Second, the establishment of ICMI was a part of Suharto's political strategy rather than a willingness to accommodate Indonesian Muslims (Liddle, 1996). However, Suharto's accommodative policies toward Muslim groups emerged as the impact of the Cultural Islam movement had been congruent with the new order's de-politicisation strategy. The movement had an effect not only on ordinary Muslim people but also on the leadership of bureaucratic and 
military organisations. The psychology of more mature Javanese Muslims also needs to be considered. Older Muslims typically pay closer attention to their religious deeds. It is worth noting that Suharto wished that it "be known that when he died, he would like the Muslims to pray for him" (Vatikiotis, 1998, p. 131). In an interview with Vatikiotis (1998), Habibie touched on Suharto's Muslim affinities, referring to Suharto's statement: "I was born a Muslim. I will struggle for the Muslim cause" (p. 131)

\section{Islam and politics in Indonesia's democratic era: Pre-Yudhoyono era}

The democratic era that followed the fall of Suharto created more opportunities for all members of Indonesian society, including Muslims, to express their aspirations. The presence of Islam in the public sphere has been more apparent not only in the cultural arena but also in the ideological and political realms. This phenomenon has certainly contradicted secularist perspectives in which religious symbols and identities are kept in the private domain (Weck et al., 2011). According to Habermas (2006), the democratic era enables a variety of aspirations to be present in the public sphere. It allows religions to be in the public sphere as they generate democratic process legitimacy. The practice of democracy in Indonesia encouraged Muslim groups and offered the opportunity for them to return to the political arena. The involvement and accommodation of Islam in political parties has reflected a distinctive feature of the democratisation process in the country (Carnegie, 2006).

More than 20 Islamic parties participated in the 1999 elections (Fealy et al., 2006). It must be noted that questions exist regarding the definition of Islamic parties, and it is a difficult task to clearly define them. The author follows the categorisation of Islamic parties presented by Azra (2006). There are at least two main features identifying a party as Islamic. First, there are those that have officially adopted Islam as their ideological basis as mentioned in their founding documents. These included PPP, the Crescent Star Party (Partai Bulan Bintang-PBB), Islamic Nation Party (PUI), and New Masyumi Party. Fealy (2001) labels such parties as formalistic Islamic parties for their adoption of Al Quran and As Sunnah (prophet tradition) as their sole ideological basis.

The second group are those still committed to adopting Pancasila as their basis. They still utilise obvious Islamic attributes such as Arabic scripts and pictures with Islamic nuances as well as other symbols widely attributed to Islam. Though these parties are perceived as 
pluralistic, they are in fact Muslim-based parties. They have been supported by Islamic social organisations such as NU and Muhammadiyah. These parties include PKB which is commonly associated with $\mathrm{NU}$, and PAN whose traditional supporters are people associating themselves with the Muhammadiyah (Azra, 2006). These parties are labelled by Fealy (2001) as Pluralist Islamic parties.

The establishment of new Islamic parties gained greater momentum with the repeal of the 1985 Mass Organisation Law on the obligation of each political party and mass organisation to make use of Pancasila as its sole foundation (Azra, 2006). Aside from an indication of democratic euphoria, the establishment of many political parties might not be motivated by genuinely religious motives but instead by the interests of some Muslim elites in gaining political power (Azra, 2006). Forty-two Islamic parties emerged before being verified to contest the 1999 election. There was a hope that more Muslims would vote for Islamic parties like in 1955 as a result of santrinisasi during the New Order (Fealy et al., 2006). The rise of Islamic parties recalled old debates regarding Islam and state relations. There was a concern that the Cultural Islam approach, which was predominant during Suharto's New Order, would be replaced by Islamic political formalisms (Azra, 2006, p. 20).

However, there is no indication that Indonesian Muslims, at least those represented by Islamic parties, are aspiring for the establishment of an Islamic state. No single Muslim leader has officially announced the necessity of the establishment of an Islamic state at the expense of Pancasila. Even the Justice Party (Partai Keadilan) or PK, which later became PKS, has maintained that Islamic substance is more important than the label (Azra, 2004). PKS is regarded as representing a new Islamic political resurgence. The embryo of PKS was born from the 'Tarbiyah movement'. The cadre recruitments and basic trainings of PKS utilise the study circles (halaqah) of the Tarbiyah movement. PKS is also known as the Ikhwanul Muslimin (Egyptian Muslim Brotherhood) of Indonesia. Among Islamic parties, PPP and PBB campaigned for the return of the Jakarta Charter in the early democratic era, but to no effect. NU, for example, through its sponsored party of PKB, strongly opposed the idea. (Liddle, 2003). Therefore, it is safe to say that most Islamic parties did not want to emulate the models of Pakistan and Saudi Arabia (Fealy, 2003b). In the following general elections in 2004 , there was no campaigning for the establishment of an Islamic state or to revive the Jakarta Charter from PKS, PBB or other Islamic parties. 
Instead, they preferred to promote other issues, such as good governance, in their political campaigns.

Despite their optimism, Islamic parties did not win the votes they expected. The 1999 election confirmed the victory of non-Islamic parties with $62.2 \%$ of the total vote. Meanwhile, Islamic parties only reaped $37.5 \%$ of the total vote. Partai Demokrasi Indonesia Perjuangan (Struggle Indonesian Democratic Party) or PDIP led by Megawati received $34 \%$ of the vote, Golkar (22\%), PKB (13\%), PPP (almost 11\%), and PAN (7\%) (Lee, 2004). Compared to the 1955 election where Islamic political parties garnered $43.5 \%$, there was a significant shortfall in their share of the vote. As the election winner, PDIP was not able to usher its chairwoman, Megawati, into the presidency. Instead, the Indonesian People's Consultative Assembly (MPR) elected Abdurrahman Wahid as the fourth president and Megawati as the vice president. This circumstance occurred when Islamic political parties of both modernist and traditional orientations were united to form 'the central axis' political coalition.

From its inception, the coalition seemed fragile, and Abdurrahman Wahid of PKB was, as a result, initially reluctant to be pushed as an alternative presidential candidate. PKB doubted the seriousness and solidarity of the central axis members. When the coalition insisted on pursuing its political goal, Wahid became the fourth Indonesian president. According to Fealy (2003b), “Abdurrahman's election appeared to show Islam's power as a legitimating force in Indonesian politics. He was the first genuine Islamic leader to hold the presidency" (p. 150).

Only a short period of time passed before the disunity of the central axis became apparent. Amien Rais, the chairman of PAN and former chairman of Muhammadiyah who had encouraged Wahid to the presidency, also prominently advanced Wahid's impeachment. As the chairman of MPR, he inaugurated Megawati as the fifth Indonesian President and Hamzah Haz, chairman of PPP, as vice president. The central axis has been the only coalition among Islamic political parties in the post-Suharto period. Other Islamic parties such as PKB, PPP, and PBB have experienced well-known internal conflicts. 


\section{Islam and politics in Indonesia's democratic era: TheYudhoyono era}

The 2004 direct presidential election brought Yudhoyono and Jusuf Kalla to power. Voters preferred to vote for Yudhoyono, a nationalist candidate rather than Amien Rais, chairman of PAN, Hamzah Haz, and chairman of PPP as Indonesian president for the period of 2004-2009. In fact, Islamic political parties achieved a significant number, namely: 38.35 percent of the the total vote in the 2004 legislative election which was conducted prior to the presidential election (Al-Hamdi, 2013). However, all major Islamic parties, namely: PKB, PPP, PKS, and PAN joined Yudhoyono's Democrat Party (PD) to form a governing coalation.

Together with PD, these major Islamic parties ushered Yudhoyono to the second term of his presidency (2009-2014) (Sabri, 2012). There were not any prominent Muslim figures or leaders of the Islamic parties running for the presidential election. Likewise, compared to their achievement in 2004, they performed poorly in the 2009 legislative election, reaping only $29 \%$ of the total vote (Tanuwijaya, 2010).

The 2014 general election showed similar trends. Islamic parties still could not manage to defeat nationalist parties in the election despite increased votes. They gained $31.4 \%$ in 2014, a slight increase compared to their votes in 2009 (Aspinall \& Mietzner, 2014). Despite their poorer performance than the nationalist parties, the significance of the total votes of Islamic parties cannot be overlooked. A $31.4 \%$ share of the vote is well beyond the $20 \%$ needed to propose a presidential candidate. However, disagreements among Islamic political parties meant they could not manage to propose a candidate from their own parties. Instead, each decided to make a coalition with nationalist parties. Therefore, some Islamic parties joined the Red-White coalition (Koalisi Merah Putih) or KMP backing the candidacy of Prabowo Subiato, while other Islamic parties joined the Great Indonesia coalition (Koalisi Indonesia Hebat) or KIH, backing the candidacy of Joko Widodo who in 2014 became the $7^{\text {th }}$ Indonesian president.

Based on the election results in the post Suharto era, some observers have argued that political Islam in Indonesia failed (Ahmad, 2014) and that religious factors are insignificant in Indonesian politics. The enhanced piety of Indonesian Muslim society has not been reflected in political preferences (Mujani, Liddle, \& Ambardi, 2011). Aside from the great influence of Cultural Islam vis-à-vis political Islam, other factors that may have 
contributed to the failure of Islamic political parties were their lack of an economic agenda and the issue of political Islam as a divisive factor. The latter factor has been prominent, as Muslims have no consensus on whether a more Islamic state may be formalistic and legalistic or substantive and cultural. The imposition of shariah law is also a contentious issue among Indonesian people, including Muslims (Bush, 2008; Lee, 2004). The contestation between traditionalist and modernist movements, in particular militant modernist groups such as the Tarbiyah movement, has been a determining factor for the disunity of Islamic political parties. In fact, the root of the political rivalry between modernists (e.g. Muhammadiyah) and traditionalists (e.g. NU) became apparent at the surface when NU left Masyumi in 1952 feeling itself marginalised within the party. From this time on, according to Fealy et al. (2006), "tension and acrimony between modernist and traditionalist became a hallmark of political Islam. Although both sides continued to speak of Muslim solidarity, on most issues they saw themselves as rivals who were competing for legitimacy within, and leadership of, the Islamic community” (p. 45).

According to Mujani and Liddle (2010), Indonesian voter behaviour appears to be largely secular. This is not significantly related to sociological and cultural factors, but mainly to religious, ethnic and social class-related aspects. The voters' choice was influenced mainly by contesting political characters and the degree of their association or identification with political parties. Another important factor is the government's performance. The ruling party that supports the incumbent government will be greatly influenced with regard to vote getting. In 2009, voters preferred to choose the Democratic Party (PD) in the legislative election and voted for Yudhoyono as their president. At that time, the voters' decision to re-elect Yudhoyono might have been based on their view of the success of the first period of Yudhoyono's administration in which the PD was his ruling party (Mujani et al., 2011).

Aside from the role of rational choice in voting, this political phenomenon (which has been labelled by some observers as 'the failure of political Islam') has been commonly associated with the direct or indirect effects of the Cultural Islam movement and the new order's de-politicisation strategy. Both brought about significantly diminishing gaps between nationalist and Islamic political parties. It is my conviction that the Indonesian population may generally view that both nationalist and Islamic political parties offer a similar program. They tend to vote for parties that have an ability and commitment to 
deliver their promised programmes. So far, nationalist parties are regarded as more competent than Islamic parties in this regard. According to Tanuwijaya (2010), all Indonesia's competing parties, regardless of their official ideologies, tend to shift to middle-ground, melting pot ideologies, and from secular to religious views. Golkar and PD are no longer suitably categorised simply as secular nationalist parties as they are very accommodative to Muslim aspirations. Instead, they would better be positioned as religiously accommodative nationalist parties. Meanwhile, Islamic parties, especially nonformal Islamic parties would better be called open inclusive political parties where they oppose the establishment of an Islamic state.

Second, Cultural Islam and the New Order's de-politicisation enabled santri to penetrate the nationalist parties. This was a result of diminishing suspicion towards santri Muslims with regard to the establishment of an Islamic state, creating a harmonious relationship between Muslims and other political forces (nationalists). This situation opened the way for santri Muslims to be involved in nationalist political parties rather than in Islamic political parties. For example, 83 percent of the Golkar members of parliament in the period 2004-2009 were Muslims, most of them with a santri background (Baswedan, 2004). Akbar Tanjung and Jusuf Kalla, former Golkar chairmen, have strong santri backgrounds. Both were activists within Muslim Student Associations (HMI). There has also been 'santrinisasi' within nationalist parties, leading to their accommodative policies and programs regarding Muslim aspirations. The most secular nationalist party, PDIP, even established Baitul Muslim Indonesia (Indonesia Muslims' House) where Chairman of NU, Said Agil Siraj, is one of theAdvisory Council members in the period of 2010-2015. Similar circumstances are demonstrated by PD. Majelis Dzikir SBY (God's remembrance council of SBY), which has religious activities aiming at securing Muslim support for Yudhoyono and PD. Golkar also established an Islamic organisational wing earlier than any other nationalist party. In 1978, Golkar established Majelis Dakwah Islamiyah (Islamic Da'wah Council) or MDI. Prior to that, in 1971, Golkar invited Gabungan Usaha Perbaikan Pendidikan Islam (the Joint efforts for the improvement of Islamic Education) or GUPPI to become its organisational wing (Kholil, 2009).

Many legislative policies confirm that nationalist parties have not demonstrated their 'basic' character which shies away from Islamic causes. Tanuwijaya (2010) argues that one or more shariah-based local law has been implemented in 74 districts in the period of 
2004-2009. Surprisingly, in 42 out of these 74 districts", more than $50 \%$ of the votes belong to major nationalist parties. And in 72 of the 74 districts, nationalist parties along with PKB and PAN collected more than $50 \%$ of the total vote. Not only pluralist Islamic parties such as PKB and PAN, but also nationalist parties are ideologically supposed to prevent shariah-based local laws from happening. Almost half of those districts are traditional Golkar strongholds. Similar phenomena occurred at the national level in the period of 2004-2009. Golkar and PD even frequently collaborated with Islamic parties in tackling controversial religious issues. A contentious education bill was successfully passed and became Law No. 20/2003 on Education because of the support of Golkar (Baswedan, 2004; Tanuwijaya, 2010). The bill was controversial because it obliged any private schools, including non-Muslim schools, to provide religious teachers for students from a different religious background. A Catholic school, for example, was obliged to make available an Islamic religious teacher if it had Muslim students.

Nationalist parties such as Golkar and PD also supported the passage of the controversial anti-pornography bill in 2008 (Tanuwijaya, 2010). All nationalist parties also endorsed a joint three ministerial decree in 2008 concerning the Ahmadiyah sect, which is a very controversial issue. Human rights activists opposed the government's semi-ban on Ahmadiyah as it threatened religious freedom. The decree prevents Ahmadiyah followers from practising and proselytising their beliefs. The government issued the decree to prevent further violence from occurring, especially from those opposing Ahmadiyah (Sukma, 2010). This undeniably indicates the difficulty of disregarding the role of Muslim aspirations in Indonesia's domestic politics, though sometimes the pressures stem from militant Muslim groups in Indonesia’s daily political life.

The Cultural Islam movement and Suharto's accommodation of religious aspects along with the external influence of a religious resurgence in the public sphere provided the impetus for Muslims to express their faiths in various ways (Hasan, 2009). Their 'Islamic expression' has increasingly moved into the centre of public life. This expression takes various forms, ranging from political and economic activities to social-cultural activities. It has become common for religious gatherings to be conducted at 5-star hotels. Pilgrimage to Mecca both for umroh - a small haji that can be conducted anytime - and haji which is conducted in the month of Dzulhijah according to the Islamic calendar-have become a new lifestyle. Instead of spending their holidays somewhere else, many Muslims prefer to 
do umroh. TV entertainment programs frequently broadcast artists' or entertainers' experiences when they perform umroh, Ramadhan fasting and other religious activities.

Wearing the jilbab (veil) does not necessarily indicate the piety of Muslim women. Instead, it can also be considered a fashion statement. Fealy and White (2008) have described aspects of the contemporary development of Indonesian Muslims, contending that Muslims are more aware of putting their money in shariah banking, browsing Islamic websites, using halal cosmetic products, watching religious television programs, and enjoying Islamic art and displaying it in the home than ever before. Others are more concerned about macro Islamic issues regarding how to strengthen religious morals in the state and society.

Recently, the contemporary Islamic landscape has become more dynamic with the emergence of a Middle Eastern-oriented Islamic movement challenging the old Islamic mainstream organisations, Muhammadiyah and NU. The presence of transnational Islamic movements such as HTI and the Salafi Wahabi movement has instigated debate and controversies in Indonesia (Bruinessen, 2013a). What has been achieved by the Cultural Islam movement has, to some extent, been disturbed and downgraded by these movements. This situation has worried foreign observers who fear that the smiling/friendly Islam in Indonesia could be overshadowed by the emergence of conservative Islam (Fealy \& White, 2008). However, this anxiety is contested by Azyumardi Azra (interview, 25/10/2013) and by Martin Van Bruinessen. According to Bruinessen, the image of a rise in conservative Islam at the expense of mainstream Islam is based on a 'superficial reading' on Indonesia's political development in the post-Suharto period (Bruinessen, 2013b). Indeed, despite their active expression in the public sphere, mainstream Islam is still prevalent. The new 'irritating' movements remain very limited in number.

The discussion above demonstrates that although the increasing piety of society did not translate into the victory of Islamic political parties over nationalist parties in the elections, Muslim aspirations have become among the most prominent issues to be taken into consideration by Indonesian regimes in the post-Suharto period. It is within such a domestic political context, that Indonesia's foreign policy has also been constructed.

The increasing influence of Islam in domestic politics is not only limited to the support of nationalist parties on laws favouring Muslim groups but it has also appeared in various 
other fields in a variety of ways. The failure of some Islamic political parties, especially PPP and PBB, to revive the Jakarta Charter seemed to be compensated by the successful repeal of the 1985 Mass Organisation Law on the obligation of each political party and mass organisation to make use of Pancasila as its sole foundation.

Prior to the passage of Law No. 20 of 2003, the state's accommodation towards Muslim aspirations regarding education was clearly seen in the adoption of Article 31, especially verses 3 and 5 of the amended 1945 Constitution. Article 31 (3) states that "the government shall manage and organise one system of national education, which shall increase the level of spiritual belief, devoutness and moral character in the context of developing the life of the nation and shall be regulated by law". Meanwhile article 31 (5) stipulates that "the government shall advance science and technology with the highest respect for religious values and national unity for the advancement of civilisation and prosperity of humankind". The repeal of 1985 and the adoption of Article 31 (3) and Article 31 (5) has, according to Hidayat Nurwahid, a PKS leader, exemplified the strengthening influence of Islam in Indonesian politics (interview, 2/12/2013).

The place of Islam became more noticeable the more the state endorsed those laws and policies favourable to Muslims. First, during the legislative process strengthening legal instruments on shariah banking/finance, marked by the adoption of Law No. 21 of 2008 on shariah banking, almost all factions representing political parties in the DPR agreed on its adoption (Asriani, 2008). This law has strengthened the place of shariah banking as an integral part of the national banking system. Consequently, Indonesia constitutes a country following dual banking systems, where shariah banking and conventional banking systems operate side by side (M. Arifin \& Nasution, 2015). Earlier, law No. 19 of 2008 on shariah obligation was also endorsed. Such an obligation is expected to attract more Muslim investors (Fatah, 2011). Yudhoyono set in place a policy supporting the development of Shariah banking. He launched a Shariah Economic Movement (Gerakan Ekonomi Shariah). His government aspired to have Indonesia become a centre of the world shariah economy, and at the same to be integrated with the international shariah system (Aryani, 2013).

Second, responding to the increasing piety of Indonesia's Muslim society, and especially their readiness to pay zakat (almsgiving) and to donate their wealth in the forms of infaq- 
shodaqoh (giving a donation for the sake of God) and waqaf (the Muslim practice of property endowment for public or religious uses due to religious cause), DPR endorsed Law no. 41 of 2004 on Waqaf and Law no. 23 of 2011 on the management of zakat, infaq, and shodaqoh. Law no. 23 of 2011 has amended and revised the law No. 38 of 1999 on the management of zakat. Third, the legal instrument securing Muslim aspirations for the availability of approved halal products was firmly established by the adoption of Law No. 33 of 2014, less than one month before Yudhoyono ended his presidential term on 20 October 2014 (Maharani, 2014).

Finally, the Yudhoyono administration's unwillingness to repeal the Blasphemy Law no. 1/PNPS/1965 undeniably indicated a pro-Muslim group policy. Muslim groups believe that such a law functions to protect Islam as a majority religion as well as to avoid heretical practice in religious teaching. During the Yudhoyono era, there had been some prosecutions for persons or certain religious sects accused of insulting a religion, especially Islam. This raised protests from human rights and pluralist activists. The perceived misuse of the Blasphemy Law was condemned by both local and international human rights organisations (Crouch, 2012). Amnesty International, for example, put pressure on the government to repeal the law. However, the implementation of the law has been maintained by the Indonesian government as it has mulled over the interests of Muslim groups still willing to enforce the law of Blasphemy. In this regard, NU and Muhammadiyah and other Muslim groups worked hand in hand to try to stem the agenda of NGO activists, especially when they proposed a judicial review of the Blasphemy Law by the Indonesian Constitutional Court. As a result of Muslims groups' pressure, the NGO activists' request for judicial review was rejected by the Court (F. A. Arifin, 2014).

Yudhoyono even proposed an international protocol against blasphemy at the $67^{\text {th }}$ UNGA in September 2012. This was in response to Muslim protests around the world including violent protests staged by 1000 conservative Muslims at the US Embassy in Jakarta in early September 2012 which was fuelled by a provocative film The Innocence of Muslims (Lamb, 2012). Despite claiming that Indonesia had few credentials to promote the issue due to the perceived abused use of the Blasphemy law domestically, Indonesia proceeded to develop a roadmap for the protocol. However, Yudhoyono's initiative does not seem to have materialised. His initiative was clearly directed at a domestic audience. The problems that might be faced in pursuing such a protocol were well-understood by the Indonesian 
government. Foreign Minister Natalegawa expected that countries like the US which allow freedom of expression would object to such an idea (Antara, 2012b). Therefore, the government wanted to show its understanding to Muslim groups in Indonesia about their concerns.

The role of Muslim groups, and mainly of NU and Muhammadiyah in the process of passing these laws, has been crucial as they are the main stakeholders in these concerns. The DPR usually invites NU and Muhammadiyah as well other relevant Muslims groups to public hearings. For other cases, members of parliament and the government visit their offices (headquarters) to discuss and consult on many issues. It is sensible for the government and DPR to consult with NU and Muhammadiyah as well as other Muslim groups, including when DPR discusses bills of concern to Muslims (interview with Hidayat Nurwahid, 2/12/203).

Conversely, the opposition of Muslim groups to policies or proposed bills typically has a large influence on the process of government decision-making or on the process of legislation in DPR. NU, for example, has opposed the passage of a bill on tobacco, and its opposition has caused the delay of the bill's adoption. This is because-according to NU - the bill proposed by the government will badly affect the lives of tobacco farmers in the country. NU argues that the limitation of tobacco products as enshrined in the bill should be based on the public interest and not the interests of certain groups. The ratification on the Framework Convention on Tobacco Control (FCTC) has allegedly driven the government to propose such a bill limiting tobacco products (Zubaidah, 2014). In the case of Muhammadiyah, from the end of 2012 to early 2015, this organisation proposed judicial reviews four times on laws that it considers have caused adversity to society. It lodged four laws to be judicially reviewed by the Indonesian Constitutional Court, namely Law No. 22 of 2001 on Oil and Gas, Law No. 44 of 2009 on Hospitals, Law No. 17 of 2013 on Mass Organisation and Law No. 7 of 2004 on Mineral Resources. All of Muhammadiyah's lawsuits were accepted by the Constitutional Court although not all articles proposed by the organisation were agreed upon. Its success in previous judicial reviews made this organisation more confident and it has prepared judicial reviews on other laws it sees as non people-oriented. For example, at present, it is preparing to propose judicial review on Law No. 25 of 2007 on Foreign Investment (Biyanto, 2015). 


\section{Conclusion}

Islam was a source of resistance and nationalism in Indonesia's colonial period. The modern Indonesian movement was also pioneered by an Islamic organisation. As such, Islam was regarded by the Dutch authorities as a threat that needed to be marginalised politically.

The battle between Muslims and nationalist groups began in the formative years of the Indonesian state. Their political compromise was the acceptance of Pancasila as the state's foundation, defining Indonesia as neither religious nor secular. Islamic parties still struggled to realise what they perceive as an ideal form of state in the Sukarno era. They demanded the inclusion of the Jakarta Charter in the country's constitution but their demand was not accommodated. The Charter, requiring the upholding of Islamic shariah for its adherents, united the fragmented Islamic political parties. Their lack of success did not eliminate Islam as an important factor in Indonesian politics. Islamic political parties enjoyed a role in the liberal democratic era from the early 1950s to the late 1950s.

The role of Islam in Indonesian politics had declined significantly by the early 1970s when Suharto's de-politicisation strategy was enforced. Islam was politically marginalised. Suharto's policy seemed to adopt Hurgronje's Dutch approach. He barred Islam from politics and at the same time encouraged its religious rituals. This pushed Islamic leaders to find a strategy that did not contradict the government policy but still benefitted Muslims. Spearheaded by Muslim intellectuals such as Nurcholis Madjid and Abdurrahman Wahid, along with the efforts of Muhammadiyah and NU, Cultural Islam was promoted as the way Islam could struggle on under the authoritarian regime. Cultural Islam encouraged Islamic symbols and was not confined to rituals and worship, but it thrived beyond that, reaching all aspects of life. However Cultural Islam was transformed into a cultural movement. Jilbab, for example, did not merely reflect 'the assumed' obligation for a women to wear it and use it when attending religious gatherings, but was also transformed into a fashion. The Cultural Islam movement proved effective in easing the tensions between Islam and the state, leading to Suharto's accommodative policy toward Islam in the 1990s.

This movement has had a great influence on Muslim perceptions of the relationship between Islam and the state. Except for radical new groups, Indonesian Muslims do not 
deem it necessary to establish an Islamic state. Likewise, they do not believe that it is only Islamic parties which can accommodate their aspirations. Consequently, together with Suharto's de-politicisation, this movement contributed to the change of Muslim political behaviour including their electoral behaviour and the diminishing factor of aliran politics (the political stream) which was prevalent in 1950s.

Therefore, the electoral defeat of Islamic political parties does not necessarily suggest the decline of Islam in Indonesian politics. Rather, Islam has expanded its political influence over nationalist parties with regard to the way in which they adopt Muslims' aspirations. The ruling party of PD and its coalition have applied an accommodative approach towards Muslim aspirations. With the diminishing political stream, there have not been significant differences between parties' ideologies and platforms. Political coalitions are formed based on political pragmatic interests. In this context, all Islamic political parties were parts of Yudhoyono administration's coalition after 2004. Perhaps this phenomenon has been best described by Nasr (2005), who writes that "regular competitive elections have both pushed religious parties toward pragmatism and pulled other parties into more diligent efforts to represent Muslim values" (p. 19). 


\section{CHAPTER THREE \\ THE ROLE OF ISLAM IN INDONESIA'S POST-SUHARTO FOREIGN POLICY}

\section{Introduction}

The previous chapter showed that the emergence of Islamic political parties, the proliferation of Muslim organisations and the increasing presence of Islam in Indonesia's public sphere can be regarded as manifestations of the increased role of Islam in Indonesia's domestic politics. Has Islam's increasing role in domestic politics brought about the same trend in foreign policy? To answer this question we first need to discuss the extent to which Islam as a political and moral force influences Indonesian foreign policy. This chapter starts with the argument that Muslim groups have had more influence on Indonesian foreign policy after the shift from Suharto's authoritarian era to a more democratic regime.

Many previous studies on Islam and Indonesia's foreign policy usually conclude that Islam has a marginal role to play in external affairs. Islam in this regard has been portrayed as a political ideology driving foreign policy. Ideologically, Islam and other religions have never been formally admitted as driving factors in any of Indonesia's policies. However this study, which stresses the 'moral and political' influence of Muslim interest groups, will provide a different nuance regarding Islam and foreign policy in the context of a democratic Indonesia.

Despite being home to the largest Muslim population in the world, for decades Islam never had a salient position in either the domestic politics or the foreign policy of Indonesia. It is only since the arrival of the democratic era in the late 1990s that Islam has grown salient, including in domestic politics. This phenomenon has been marked and driven by the rise of Islamic political parties and the growing role of Muslim groups and organisations. Indeed, Indonesia had in fact disengaged from the world's Islamic affairs, particularly during the pre-democratic era. The country seemed to be holding itself back from playing a prominent role. Many observers have referred to this as Indonesia 'punching below its weight' in the Muslim world (Pitsuwan, 2012).

This chapter will outline the basic tenets of Indonesia's foreign policy and its interpretation with regard to issues that have concerned Muslims. The subsequent discussion will touch 
on the influence of democratisation and the role of Islam in foreign policy, including the government's response to Muslims' aspirations, particularly in relation to international events. This chapter then explores the projection of Indonesia's international identity as the largest democratic Muslim country in the world, and the country's new international activism in becoming a role model for other Muslim countries with regard to Islam, democracy and modernity. In this chapter, Putnam's approach is used to analyse the Indonesian government's policies as a result of the pressures from both the US and Muslim groups with regard to the 9/11 incident, the Bali bombings, and the Iraqi and Afghan wars. At the same time Skidmore and Hudson's statist-pluralist approach will be used to investigate the emergence of foreign policy actors other than the government of Indonesia in the post-Suharto era and how they interacted with the government as well as the inclusion of Islamic elements in Indonesia's foreign policy.

\section{Basic tenets of Indonesia's foreign policy}

Change and continuity has been a feature of Indonesia's foreign policy from the Sukarno era until the present day. As well as abiding by Pancasila and the 1945 constitution as its principled foundations, Indonesia has always advocated an 'independent and active' principle as a guide for its foreign policy. This was first put forward by Hatta in September 1948, against the backdrop of Cold War rivalries.

'Independent' in this context means, 'Indonesia plays no favourite between the two opposed blocs, and walks its own path through various international problems" (Hatta, 1953, p. 444). This independent stance was expected to enable the country to determine its policies according to its national interests, "neither submitting to the pressures of other countries nor aligning itself with any power bloc" (Hatta, 1973, p. 11). Hatta disagreed that this implied neutrality in Indonesia's foreign policy. In the context of international solidarity, neutrality was interpreted as "an anti-social status" that cannot be adopted by Indonesia (Hatta, 1953, p. 443). An independent policy does not mean standing alone. 'Active' in this context means "the effort to work energetically for the preservation of peace and the relaxation of tension generated by the two blocs, through endeavours supported if possible by the majority of the members of the United Nations" (Hatta, 1953, p. 444). The background of the Cold War was still very much present at the establishment of this foreign policy principle. Nonetheless, the principle endures and has become a constant feature of Indonesia's foreign policy in the post-Cold War era (Sukma, 1997). 
Along with Pancasila and the 1945 Constitution, the bebas-aktif (Independent-active principle) has ensured continuity in Indonesia's foreign policy aims since the early era of Indonesia's independence.

Islam has been embraced by the majority of the population, but it is given the same status as the other five formally recognised religions. Islam has never been the philosophical basis of the state nor an official state religion. Like other states with a Muslim majority, Indonesia faces the issue of how to accommodate Muslim aspirations in political life and how to carry out foreign policy in an appropriate manner. Muslim political aspirations cannot be disregarded, particularly in the democratic era. However, satisfying Muslim concerns toward international Muslim causes is not always easy.

Leifer (1983a) and Sukma (2003) argue that problems involving Muslim causes and the state's formal identity have not been totally resolved. This is a persistent challenge that requires the state to tread carefully. Such situations place Islam in a peripheral and secondary position, leading to its relative absence in Indonesia's foreign policy. The unresolved relationship between Islam and the state's identity has brought about a symbolic or rhetorical accommodation of Islam in foreign policy. Thus, this is an 'accommodation' not in 'substance' but rather in 'form'. Political pragmatism has led to a 'symbolic accommodation toward Islam' (Leifer, 1983b; Sukma, 2003). Indonesia's relations with Middle Eastern countries, for example, have not been based on co-religionist or Islamic considerations, but pragmatic motives. Moreover, in the Suharto regime "the government took great care not to allow foreign policy to be dictated by Islamic considerations" (Sukma, 2003, p. 62).

This conclusion may be applicable if 'state identity' is the main reference point. However, this position falls short when examining political realities. For example, former Foreign Minister Hassan Wirajuda acknowledges that issues where Muslims are concerned have not been freely articulated, emphasising that these are more form rather than substance (interview with Hassan Wirajuda, 17/12/2013). Interviews suggested that the government has substantially accommodated Muslims' concerns as long as they do not challenge Pancasila, the 1945 Constitution, and the independent and active principle of foreign policy. 
In this author's view, Pancasila and the 1945 Constitution do not directly stipulate how foreign policy should be conducted, however, they do provide a guide. The principle of humanitarianism is commonly cited as an ideological rationale for foreign policy action, including issues pertaining to Muslim Rohingya, Muslim Bosnia, Muslim Kosovo and Palestine. As well as this humanitarianism base, Indonesia's active foreign policy in relation to Palestine is also based on aspects of anti-colonialism. Colonialism goes against the values enshrined in Pancasila, namely humanitarianism and social justice. This anticolonial stance also derives from the 1945 Constitution that requires the country to strive for the elimination of colonialism and for the promotion of a new world order based on independence, perpetual peace and social justice.

There has been a gradual shift in the way Muslim aspirations are expressed with regard to foreign policy. Initially reluctant to formally join the OIC, Indonesia is growing more assertive within this Islamic multilateral organisation. Established at Rabat in 1969 as a response to the burning of $\mathrm{Al}$ Aqsa Mosque in Jerusalem, the OIC set up its permanent secretariat in Jeddah in 1970. Indonesia sent its first delegation to the OIC meeting of March 1972. The purpose of the meeting was to form a charter with the main objective, among others, to 'promote Islamic solidarity among member states'. The charter's articles state that "every Muslim state is eligible to join the Islamic Conference on submitting an application expressing its desire and preparedness to adopt this charter" (OIC, 1972, p. 115). This could be interpreted as OIC membership reflecting affirmed state identity. Facing the dilemmas caused by dynamic domestic politics, the government of Indonesia did not sign the charter and declined formal membership in 1972 (Leifer, 1983b). At that time, it was thought that becoming a signatory party would automatically cause Indonesia to be regarded as an Islamic state, a move that was treated with caution. Despite not being a full member of the OIC, Indonesia continued to participate in the organisation's programs and activities. However, as Perwita (2007) argues, this participation was more to implement an independent and active policy rather than to express any Islamic sentiments.

By the 1990s, Suharto's policy towards the OIC had changed. Criteria for membership had changed from being a "Muslim state" to having a 'Muslim majority' (Perwita, 2007, p. 47). Suharto's political rapprochement with Muslim groups contributed to the shift of the country's standing in the Muslim world, especially within the OIC. Its full membership in 1990 and Suharto's attendance for the first time at the OIC summit in Dakar, Senegal in 
1991 was clear evidence of this shift. Currently, Indonesia's image as a 'Muslim country' is hardly controversial. Indeed, Indonesia openly claims to be the largest Muslim country in the world with a democratic political system.

Although there had been efforts to play a more active role in the OIC and throughout the Muslim world by the end of the Suharto era, Muslim aspirations still could not be freely expressed using formal symbols. The government continued to play down the Islamic factor as it was feared that any recognition would provide a political platform for domestic political actors, especially Muslim groups, to dictate foreign policy. For instance, the government frequently worked to avoid condemning the United States and its allies despite pressures from Muslim groups (Azra, 2006). When the Iraq War broke out in 1991, the government put religious issues aside in responding to the war, which had sparked great protest among Indonesian Muslims against the United States and its allies. Instead, the government emphasised the need to assist the Iraqi people in the fields of humanitarianism and the economy (Azra, 2006, p. 101).

The author argues that this accommodating policy toward Muslim groups regarding Islamic causes was frequently wrapped and packaged in the framework of implementing Pancasila, the 1945 Constitution, as well as Indonesia's 'independent and active' foreign policy principle. The government seemed to substantially adopt Muslim aspirations at the same time it disregarded Islamic factors in its official forms or symbols.

The independent and active principle has become a constant feature of Indonesia's foreign policy. It is truly a unique concept to Indonesia, and has remained unchallenged until now. According to Weinstein (1976) and Sukma (1997), the concept has survived due to a number of flexible interpretations. Each regime has had no choice but to enunciate an independent and active policy. All regimes from Sukarno until Yudhoyono have claimed that they conducted their foreign policy in accordance with this principle. However, the interpretation and implementation of this principle within Indonesia's actual foreign policy has been varied and subject to the flexible interpretations of each regime. Yet this variation does not mean that the independent and active principle is meaningless as a guide to Indonesia's foreign policy.

This principle in Indonesia's foreign policy has been wide-ranging since the mid-1950s, covering a no-pact and non-alliance policy, as well as the need to establish balanced 
relations with two rival blocs (Pitsuwan, 2014). Subsequently, Sukarno radicalised foreign policy in the Guided Democracy period. Bebas-aktif was defined as a core plank of Indonesia's international leadership among developing world movements which confronted neo-imperialism (Sukma, 1997). This radicalisation of foreign policy was aimed at liberating West Papua from the Dutch. This liberation was an essential symbol of national unity but it also demonstrated Sukarno's political clout (Leifer, 1983a).

Sukarno initiated a series of anti-colonial efforts including the establishment of the New Emerging Forces (NEFOS) to replace the Old Established Forces (OLDEFOS), as well as the Jakarta-Phnom Penh-Beijing-Pyongyang Axis. This nexus was intended to eliminate colonialism and neo-colonialism by the US and its Western allies.

However, whether Sukarno's foreign policy abided by the independent and active policy as defined by Hatta is subject to debate. Agung (1973) believed that Sukarno deviated substantially from the doctrine of independent and active policy, while Weinstein (1976) argued that Sukarno seemed to ignore the independent aspect and focused more on the active side.

Suharto's rise to power saw substantial changes to Indonesia's foreign policy, which became oriented more toward supporting economic development. Suharto took a more pragmatic approach to foreign policy than his predecessor. His policy was marked by closer relations with the Western countries from whom he had received aid (Sukma, 1997). At the same time, Indonesia's relationships with a number of communist countries deteriorated. However, during an interview with Keizai Shimbun in January 1998, Suharto reaffirmed his commitment to an independent and active foreign policy, and rejected the claim that he focused too heavily on the relationship with the West (Drajat, 2001).

To address its economic priorities, Indonesia returned to become a member of the UN, normalised relations with Malaysia, and sponsored the establishment of ASEAN. In Suharto's view, domestic and regional security and political stability were critical to the promotion of national economic development. In the first 20 years of his rule, Suharto's foreign policy was inward-looking and rather low profile. His foreign policy assertiveness only began in the 1990s. Many observers such as Anwar (1994) state that the international assertiveness of the last decade of Suharto's foreign policy is linked with an allegiance to the independent-active doctrine. Besides becoming a full member of the OIC, Indonesia 
chaired the Non Aligned Movement (NAM) in 1992-1995, the Asia Pacific Economic Cooperation (APEC) group in 1994, and became a peace broker in Cambodia in 1992 and in the Philippines in 1993-1996 under the aegis of the OIC (Anwar, 1994). Indonesia's foreign policy took on a higher international profile after Suharto became confident the country had made significant steps toward successful development, perhaps with the intention to parade this success to the world and to take on an international leadership role. Despite this international leadership ambition, however, Indonesia had never aspired to become a leader within the Islamic world (Suryadinata, 1995).

\section{Indonesia's democratised foreign policy}

After Suharto, the instrumental role of Islam seemed apparent during the Habibie and Abdurrahman Wahid administrations, when Islam was used in both political language and symbols (interview with Azyumardi Azra, 25/20/2013). However, according to Sukma (2003), the growing imperative of Islam in domestic politics was not automatically reflected in the country's foreign policy. As a transitional president, Habibie faced severe challenges to his political legitimacy, as he was regarded as the continuation of his predecessor. Thus, it was not expected that he would promote the aspirations of his people (Ananta, Arifin, \& Suyadinata, 2005; He, 2008).

Concerned with issues of legitimacy, Habibie distanced himself from Suharto by initiating press freedoms, releasing political detainees and liberalising political laws and laws related to political parties. During the Habibie administration, human rights laws were introduced and decentralisation of authority to the regions began. All efforts were expended in laying down the foundations of the country's democratisation. His administration also dealt with challenges related to economic recovery and public security. Overall, domestic concerns appeared to come to the fore during this era.

Habibie leveraged foreign policy to gain international support to overcome his lack of political legitimacy (He, 2008). He garnered a positive international response following his democratisation program, the 1999 general election, and the preparation of the East Timor referendum. His economic recovery efforts were also largely successful. The IMF and the World Bank lent its assistance and policy advice, which in turn improved the economy and stabilised the country's currency. The IMF and the World Bank expressed their trust in his administration, disbursing US\$43 billion and offering another US\$14 billion to aid an 
economic recovery (Schwarz, 2012, p. 373; Vermonte, 2005). However, this relatively successful record was 'rendered void overnight' by the riots sparked by the East Timor referendum. The riots were perpetrated by pro-integration militias backed by the military, damaging Habibie's international position (Anwar, 2005). Habibie was considered to have failed in resolving the complex political crisis in Indonesia (He, 2008), and lost the opportunity for another presidential term.

In contrast with Habibie, Wahid commenced his tenure with strong legitimacy and popular support. He was the first Indonesian president elected via a transparent and democratic process. Early political support for Wahid came from Poros Tengah (Central Axis), a coalition of mostly Islamic parties. The challenges he faced included a potential break-up of the country's territory, promoting good governance, the economic recovery process, and a lack of capacity to consolidate democracy. As a result, Abdurrahman Wahid's foreign policy sought international support for national territorial integrity, economic recovery, democratic consolidation, and the restoration of its tarnished international image which was perceived as a stumbling block for foreign investors (Anwar, 2005).

To achieve this goal, Wahid travelled overseas a great deal to secure international assistance, and received formal support from a variety of countries he visited. He also received assurances from the Muslim Group at the United Nations, a caucus of Muslim nations that overlaps with the OIC (A. Smith, 2000). In addition, Indonesia also secured agreements in relation to economic aid and trade relations. However, his long absences abroad resulted in a backlash at home (Anwar, 2005). Wahid visited a total of 90 countries within 21 months of his presidency, and his foreign policy was regarded as high profile but erratic. Despite maintaining a strong international vision in raising Indonesia's profile in the region and beyond, domestic concerns caused him to lose sight of this vision.

The continuing issues in East Timor placed Wahid under additional strain, and he felt that Indonesia was betrayed by the West. Australia was suspected of espionage even before the East Timor referendum, and the suspension of US military assistance strengthened that sentiment (A. Smith, 2000). Against this backdrop, Wahid proposed the establishment of a coalition of major Asian countries, widely known as 'Asia's Central Axis'. This coalition was expected to include Indonesia, India, China, Japan and Singapore, with the purpose of maintaining peace and stability in the region and building 
a just international political order (A. Smith, 2000). However, there was no clear modality or method to support his proposal to establish 'Asia's Central Axis', and the proposal failed to materialise.

Both Habibie and Wahid had strong Islamic credentials, considering their political supporters. Habibie was the chairman of ICMI, while Wahid was the Chairman of NU. Wahid was also well-known as a moderate Islamic champion, and an advocate for democracy and pluralism. When efforts were made for Habibie to step down from his presidential seat, Muslim groups from modernist-oriented organisations in particular stepped up to defend him.

One of Habibie's strongest supporters among Muslim groups was Komite Indonesia untuk Solidaritas Dunia Islam (Indonesian Committee for Muslim World Solidarity), or KISDI. This group had supported Habibie's candidacy in becoming Suharto's vice president. It accused other groups that opposed Habibie of being 'enemies of Islam'. The KISDI also staged a rally in front of the People's Consultative Assembly on 22 May, 1998, under a banner that read: "Those who Oppose Habibie are Enemies of Islam" (Sukma, 2003, p. 84). Formal support for Habibie was provided by the Golkar Party as his main political backbone. Many in this party were affiliated with the ICMI, and became more involved with Golkar during Habibie's presidency. Prominent ICMI figures included Adi Sasono and Marwah Daud, who both maintained important positions in the party. The Chairman of the Golkar party, Akbar Tanjung, was the former chairman of the Muslim Student Association and a known Habibie loyalist. Although the nationalist-oriented group was still strong within the Golkar, the party became more 'Islamized' when pro-Muslim party cadres came to play a more pivotal role (Sukma, 2003).

While both Habibie and Wahid's foreign policies might not reflect a strong Islamic orientation, their legacy in establishing democracy has impacted the foreign policy of subsequent administrations. Democratisation and other dynamic changes in the domestic political environment have swept through all aspects of Indonesian social and political life, including foreign policy and diplomacy. Previously, foreign policy and diplomacy had been regarded purely as the domain of the executive branch. Consultations between the government, parliament and other foreign policy stakeholders took place only minimally, or never even took place at all. Democratisation allowed for the involvement of more 
stakeholders in foreign policy decision-making and implementation. The involvement of a great number of non-governmental actors allowed for the reflection of more comprehensive notions of Indonesia's national interests (Alami, 2011).

Habibie laid the foundations for this democratized foreign policy with the issuance of Law No. 37/1999 on Foreign Relations. This law defines foreign relations as "every activity related to regional and international aspects which is conducted by central and regional government or its institutions, state institutions, state-owned companies, political parties, societal organisations, non-government organisations or Indonesian citizens". This definition covers a broad spectrum of actors within foreign relations, including both state and non-state actors (Alami, 2011). Meanwhile, Wahid brought about a shift from military domination to civilian supremacy, including in the realm of foreign policy. According to Dosch (2006), in the Suharto era, the Ministry of Foreign Affairs "would simply follow the unitary opinion of the President and Lemhanas (Institute for National Resilience). Now, the MFA has to listen to various opinions from the president, the parliament, military, and other stakeholders. It seems that the military's influence has significantly shrunk in the general conduct of Indonesian foreign policy" (p. 54).

The emergence of various actors in foreign policy and diplomacy has resulted in a more democratic foreign policy. However, in this context, the government through its Ministry of Foreign Affairs is still the central and dominant actor. Responding to international challenges and domestic needs, the Ministry of Foreign Affairs under the Megawati administration and the Yudhoyono administration carried out a restructuring program (Benah Diri). The program was aimed at 'linking' and 'closing' international and domestic factors. According to Vermonte (2005), the Ministry of Foreign Affairs realised that diplomacy must be understood as a way to strive for national interests as well as communicating international developments to a domestic audience. President Megawati's Foreign Minister Hassan Wirajuda deemed this concept an 'intermestic factor'. This concept was widely expressed during the presidencies of Megawati and Yudhoyono (interview with Hassan Wirajuda, 18/12/2013).

As Foreign Minister, Wirajuda also popularised the concept of total diplomacy. This concept originated from Mohammad Hatta, the country's founding father and the architect of Indonesia's independent and active foreign policy doctrine. Wirajuda frequently quoted 
Hatta's concept of total diplomacy. Here, total diplomacy is described using the metaphor of a football strategy, whereby every player has an equal opportunity to ensure the team wins the game (interview with Wirajuda, 18/12/2013).

In total diplomacy, all segments of society are involved in foreign policy formulation and implementation. Such diplomacy requires synergy from all domestic stakeholders to formulate a comprehensive foreign policy based on this intermestic approach (Alami, 2011). In the Indonesian context, total diplomacy has been concretely implemented through the 'Foreign Policy Breakfast' event which was firstly proposed and popularised by Wirajuda under Megawati's administration. This is a regular forum held at the Ministry of Foreign Affairs, where various stakeholders are invited to discuss particular issues. In this way, the government receives inputs at the same time as having the opportunity to disseminate concepts, ideas, proposals, and policies to wider society. Parliamentarians and Muslim groups are among these stakeholders, and their presence is felt when it comes to foreign policy and diplomacy.

In the post-Suharto era the government could not arbitrarily behave in the same manner as the government did prior to May 1998. Furthermore, Indonesia's parliament now has more power when it comes to foreign policy. Although two amendments of the 1945 Constitution made in the reformasi (reform) era have not negated the central power of president in foreign policy, parliament now has more power compared to its rubber stamp function during the Suharto era. Ambassadorial appointments must pass through 'a fit and proper test' conducted by parliament, and sometimes candidates nominated by the government fail this test.

In the early democratic era when all segments of society were revelling in the new democratic process, parliament tried to secure more power over the government. The parliament, particularly 'Commission I'which oversees defence and foreign affairs, had for some time positioned itself in opposition to the government. It challenged Megawati's administration, particularly with regard to East Timor and Australia.

It appears that 'opposition' to the government did not exclusively belong to 'Commission I', but in fact went even further. In early 2002, the Commission urged Prime Minister Howard of Australia to postpone his visit to Jakarta, an action immediately supported by the Speaker of DPR, Akbar Tanjung and the Speaker of MPR, Amien Rais. Both Amien 
and Akbar refused to meet with Howard (Dosch, 2006). This action was thought to be related to issues that took place in the aftermath of the East Timor referendum, the widespread anti-Australian sentiment concerning the Australian peacekeeping force in East Timor, the shared feeling that Australia betrayed Indonesia in relation to East Timor, and the accusation that Australia supported West Papua's independence.

Although a pluralistic system of foreign policy decision making has been increasingly promoted, the government has sometimes ignored stakeholders' views on certain issues, resulting in hostility toward the government. These issues include the Defence Cooperation Agreement (DCA) with Singapore in 2007, and the Iranian Nuclear issue in 2007.

In the case of the DCA, a majority of the members of parliament refused to ratify the agreement signed in Bali on 27 April 2007 by the governments of Indonesia and Singapore. This agreement was signed together with an agreement on extradition as a single package. DPR argued that the government had violated Article 11 of the 1945 Constitution on the authority of the parliament to approve or reject international agreements based on the national interest. Moreover, the government did not involve the parliament during the negotiation process, drawing accusations that it had not communicated in a transparent way with the parliament (Alami, 2011)

The parliament also objected to the content of the agreement, arguing that certain articles were more beneficial to Singapore than Indonesia. The agreement allowed Singapore to conduct its military exercises and to involve other parties when carrying out any military exercise with Indonesia. Their most significant point of contention was that the agreement could potentially threaten Indonesia's sovereignty. The parliament was clear in that it wanted the agreement to be separated from the agreement on extradition. Meanwhile, Singapore maintained that the extradition agreement would not be ratified if it was not bundled together with the DCA. Currently, both agreements are on hold. Many argue that Indonesia is in great need of the extradition agreement, as a way of retrieving illegal funds earned via corruption which are now sitting in Singaporean banks (Alami, 2011)

The interests of the parliament have often converged with other stakeholders, including Muslim organisations, when it comes to foreign policy formulation. The parliament frequently "jumped on the bandwagon" of the anti-American, anti-Israel, anti-Australia, 
and anti-Malaysian sentiment (Dosch, 2006, p. 62). When Wahid proposed opening diplomatic relations with Israel, he faced severe criticism from Muslim groups, and was charged with being insensitive. The parliament then joined the public and voiced its strong objection to Wahid's proposal. Having learned from previous experience, Wahid paid heed to the parliament's suggestion and postponed his planned visit to Australia several times. Indonesia-Australia relations at the time were at a low point in the aftermath of the East Timor referendum (Mashad, 2008). In the post-Suharto era, not involving other foreign policy stakeholders in such matters frequently generated criticism from the public and parliament. The government faced further backlash when it decided to vote in favour of the Iranian Nuclear Program Sanctions in 2007. As a non-permanent member of the UNSC, Yudhoyono's administration was accused of following the lead of the United States and other major powers. This decision generated criticism from Muslim groups as well as the parliament. Eventually the parliament used the rights of interpellation on the government, causing domestic political turbulence. This case will be discussed in greater detail in Chapter Four.

\section{Muslim aspirations and the government's response}

\subsection{The change in Islam's role}

Since the 9/11 terrorist attacks on the United States, the role of Islam in Indonesia's foreign policy has begun to change. There are at least four reasons for this development.

First, Islam was thrust into the world's spotlight in a negative way and Indonesia with its large Muslim population had a vested interest in restoring this image. In many respects, the government felt a responsibility to disassociate Islam and Muslims from terrorism. The government also sought to project a face of 'Indonesian Islam' as peaceful and moderate.

Second, the events served as an impetus for Muslim groups to become more involved in Indonesia's foreign policy. Such groups utilised this momentum to consolidate their power and show their strength on international issues that concerned them. The reformasi (reform) era and the increasingly democratised political system which followed had provided the opportunity for many aspects of society, especially Muslim groups, to have their voices heard. This led Muslim groups in Indonesia to stage strong protests when the US connected 9/11 with Islam. 
Third, unlike Sukarno and Suharto who both attempted to insulate domestic politics from international Islamic influence, the administrations of the post-Suharto era have been more open and relaxed in responding to such influence and the government has even seemed to use this factor to acquire domestic support. The government appears to have been more responsive and accommodative toward Muslim groups in regard to international issues that concern them, as long as they do not contradict sharply with the basic tenets of Indonesian foreign policy and/or fundamental national interests.

Fourth, formal political Islam and the establishment of an Islamic state are deemed to be less of a threat. This is in contrast with Suharto who was suspicious of political Islam throughout much of his rule. In fact, Islam was considered the enemy, second only to Communism. As such, only a limited number of pious Muslims were appointed to strategic positions. During his tenure Suharto preferred to take advice from Christians and nominal Muslims like himself (Effendy, 2003). The coming of the democratic era has indeed turned the situation around for Muslims.

\subsection{Domestic reaction and governmental response to the $9 / 11$ tragedy and the Afghanistan war}

The US response to the 9/11 tragedy and the way it undertook the global war on terror provoked harsh reactions from Muslims around the world. Not long after the events of 9/11, the US targeted Osama bin Laden, an Arab Muslim and head of the Al-Qaeda terrorist group, as the main suspect behind the attacks. Using the banner of Islam, AlQaeda had long advocated a terrorist campaign against the US. In the global war on terror, President Bush grouped countries into those who are 'with us', and those who are 'against us'. The attack was a turning point for the global political and security environment, as Bush's foreign policy placed the highest priority on fighting terrorism at the expense of other agendas, including the promotion of human rights and democracy. The allegation of Muslim involvement in the attack and the insensitivity of Bush in using the term 'crusade' and 'Operation Infinite Justice' (before being replaced by 'Operation Enduring Justice') incited significant resentment among Muslims. 'Crusade' was interpreted by Muslims as a reference to the war between Muslims and Christians to rule Jerusalem, and a power struggle between the two groups. The replacement of 'crusade' with the term 'Operation Infinite Justice' again bothered Muslim groups as they believe that only 'God is infinite' (Azra, 2006, p. 57). Although the term 'crusade' was not intended to refer the spirit of war 
between Christians and Muslims in the Middle Ages, it was still "presented as a moral crusade, a fight of good against evil" (Camroux \& Okfen, 2004, p. 164). Thus this choice of word was deeply insensitive in the eyes of Muslims. Such insensitivity only served to increase anti-American sentiment among Muslims around the globe. Muslims in Indonesia, especially militant groups, reacted harshly to the US for immediately linking the attack by Al Qaeda with talk of a retaliatory attack against Afghanistan after the US accused the Taliban of providing a safe haven for the terrorists responsible for the 9/11 attacks.

Although Bush denied that the United States' war against the Taliban and Osama bin Laden equated to a war on Islam, hard-line Indonesian Muslim groups believed that the US had secret plans to destroy Islam (Azra, 2006, p. 164). They also accused Megawati of being too lenient toward the US. The absence of any condemnation by Indonesia toward the planned strike on Afghanistan was considered anti-Islam and against the wishes of Muslims. At the very least, hard-line Muslim groups considered Megawati's attitude as an unfriendly signal to Islam. Prominent hard-line Muslim groups in Indonesia that expressed dissatisfaction toward Megawati and confronted US policy included FPI, Communication Forum of Ahlus Sunnah wal Jamaah (FKAWJ) and its militia wing, the Jihad Militia Force (Laskar Jihad), and HTI. MUI, and the Unity of Action of Indonesian Muslim Student (KAMMI) were also critical of the government. The latter even staged mass street protests against the attack on Afghanistan (Azra, 2006). Likewise, the moderate Muslim groups of NU and Muhammadiyah were also critical of the United States' war on terror, especially the planned attacks on Afghanistan and Iraq. This situation brought various Muslim groups into a united movement, under a singular "concern, rhetoric and action" (Hasan, 2005, p. 304). Immediately after the $9 / 11$ tragedy, Hamzah Haz, the vice president and the chairman of PPP, issued a statement criticizing the US (A. Smith, 2010). He mentioned that the US attempted to discredit Islam through the tragedy. He further stated that "the attack would hopefully cleanse America's sin" (Sukma, 2003, p. 132).

Against this background, Megawati paid a previously scheduled visit to Washington a week after the 9/11 attack. President Bush's decision not to rescind his invitation to Megawati was interpreted as an attempt to show the US was not targeting Islam or Muslims when it launched its global war on terror (Anwar, 2005). As Megawati was president of the largest Muslim country in the world, it was hoped the visit would have 
symbolic purpose. Megawati's strong condemnation of the 9/11 attack and her willingness to cooperate with the international community in the fight against terrorism were welcomed by President Bush. In return, Bush reiterated US support for Indonesia's territorial integrity (Murphy, 2010, p. 371), pledged to provide a financial aid package worth $\$ 567.7$ million, and renewed military relations including a lifting of the embargo on commercial sales of non-lethal defence equipment (Malley, 2002, p. 131). Both countries also established a bilateral security arrangement.

However, Megawati's mission was not considered to be a success by many domestic constituents, particularly Muslim groups. From their perspective, she was bought off by the US to support the attack on Afghanistan (Anwar, 2005, p. 107). In this view, the Indonesian government had been pressured to take a cautious response. Within Indonesia's domestic politics, there was a power struggle between moderate Muslim groups and less moderate organisations. At the same time, Muslim groups across the board also began to pressure the government. Militant groups utilised the 9/11 attacks and the subsequent wars on Afghanistan and Iraq to exert their legitimacy as defenders of Islam (Hasan, 2005) and to consolidate their political power. The harsh Muslim reaction might also be interpreted as a strong determination to participate in the formulation of foreign policy (Perwita, 2007). The backlash and widespread street protests by Muslim groups toward the United States' planned retaliatory action towards Afghanistan gave Megawati a small window of opportunity. According to the Pew Global Attitudes Projects (2002), the Indonesian public was mainly against the war in Afghanistan (A. Smith, 2003). On the other hand, the government itself was concerned that the United States-led global war on terror would create conditions favourable to the rise of radical Muslim groups.

Therefore, Megawati found herself in a position of having to balance domestic political aspirations and Indonesia's involvement in the global war on terror which Putnam (1988) names the 'two level approach'. In this context, the government had to reconcile both domestic and international concerns. In the domestic sphere, diplomacy and foreign policy ought to receive approval from as many stakeholders as possible, including from Muslim groups. This placed Megawati in a difficult position, and she remained silent on this issue for quite some time. Some intellectuals, such as Azra (2006), argue this silence indicated her difficulty in balancing both domestic and international imperatives. The difficult domestic challenges she faced resulted in a slow response on Afghanistan. Three things 
can explain this indecisiveness. First, she lacked Islamic credentials. Her party was regarded as the most secular or nationalist party in the country. Second, she needed the support of Islamic parties, as she could not maintain her power without them. Her ascendency to power was in fact due in large part to the Islamic parties' coalition spearheaded by Amien Rais, the chairman of PAN and former chairman of Muhammadiyah. Moreover, although her party was the largest at the time, it held less than one-third of the seats in Indonesia's parliament (Malley, 2002). Third, Megawati lacked leadership capacity in the fragmented political power structure of the post-Suharto era.

Megawati's delayed response and her silence on the war in Afghanistan was considered by less moderate Muslim groups as a soft attitude toward the US, a claim the government denied. Wirajuda argues that after the 9/11 tragedy occurred, the country had in fact maintained a clear position. He points out that Indonesia had strongly condemned the terrorist attacks. Second, he claimed, Islam was peaceful, tolerant, and anti-violence, clearly separating Islam from such acts. Third, the government maintained that terrorism threatened international peace and security (interview with Hassan Wirajuda, 18/12/2013). On this last point, Indonesia wished to emphasise that terrorism not only posed a threat to the US but also threatened international peace and security, including that of Indonesia.

Anti-American sentiment in Indonesia reached fever pitch when the US and its allies launched military operations in Afghanistan in 7 October, 2001, posing a severe challenge to Megawati's administration. The following day on 8 October, 2001, the government issued a statement outlining six key points. First, that the government was deeply concerned that military action took place following the $9 / 11$ terrorist attack. Second, that the government noted the US government's statement that the military operation was only intended for limited targets, namely terrorist training camps and military installations in Afghanistan. Attention was also drawn by the statement to the concern that the military operation should not be construed as a retaliatory act or hostility against Islam. Third, Indonesia urged that the military operation be strictly limited in terms of its intensity, targets and duration so as to minimise civilian casualties. Fourth, Indonesia called on the United Nations, especially the UNSC, to collectively respond to the situation. Fifth, the government expressed the solidarity of Indonesian society with the Afghan people, stating that actions should not be carried out unlawfully nor disturb public security and order. 
Finally, the government announced it would send humanitarian assistance to Afghanistan and urged the participation of Indonesian society in this regard (Gatra, 2001).

Although the statement was based on a deep understanding of national interest and Muslim aspirations, as admitted by the then Coordinating Minister for Political and Security Affairs Susilo Bambang Yudhoyono, it was severely criticised by Muslim groups (Gatra, 2001). Militant Muslim groups were angry as they believed the government was proAmerican and had failed to condemn the military operation in Afghanistan. Both radical and moderate Muslim groups denounced the attack, and anti-American sentiment grew strong in various cities around the country.

However, different groups expressed their discontent in different ways. Militant groups demonstrated on the streets, including in front of the US Embassy in Jakarta and US representative offices in other regions of Indonesia. They threatened US nationals and foreigners and boycotted US-related products, properties, and symbols, including McDonald's restaurants. They also pressured the government to sever diplomatic relations with the US (Anwar, 2005; Chow, 2005; Hasan, 2005). A nation-wide campaign to defend Afghanistan was also launched. These groups recruited, trained and later sent to Afghanistan a number of volunteers, of which 1800 registered for the task. These volunteers came from Jakarta, Central Java, and West Java. The Indonesian Muslim Youth Movement (Gerakan Pemuda Islam Indonesia-GPII) organised the jihad recruitment in Jakarta, and recruitment took place in a number of cities across Indonesia (Azra, 2006).

In contrast, moderate Muslim groups like NU and Muhammadiyah condemned the US action in Afghanistan but disagreed with radical groups on the sending of jihadis to Afghanistan. These moderate groups argued that jihad does not always mean 'holy war'. For instance, efforts to develop Muslim ummah also can be called jihad. They denied the notion that the 9/11 attack was a tragedy of religion, and instead framed it as tragedy of humanity. They urged the Muslim world to refrain from linking terrorist attacks to a religious conflict. In short, the moderate groups did not follow the methods of the more militant groups, despite having the same goal in condemning the US attack on Afghanistan. Muhammadiyah and NU as well as other prominent Muslim figures with a moderate orientation harshly criticised MUI which seemed to agree on the idea of calling for jihad (Azra, 2006). 
This pressure forced Megawati to reassess her 'defensive' attitude. She eventually changed her position and bowed to pressure. On the commemoration of the Prophet Muhammad's ascension at the Istiqlal Grand Mosque on 14 October, 2001 she clearly stated that "whoever commits terror must be punished, but it is unacceptable that someone, a group or even a government - arguing that they are hunting down perpetrators of terror-attack people or another country for whatever reason" (Azra, 2006, pp. 64-65). She further stressed the importance of observing existing rules, as an action initially meant to combat violence might eventually create new acts of terror and hostility. Terror cannot be resolved through terror, she argued (Azra, 2006; Sukma, 2003).

Despite refraining from openly criticising the United States, Megawati's statement was clearly targeted. Naturally, her statements disappointed Washington (A. Smith, 2003, p. 455) and its allies. The Australian prime minister John Howard also criticised her stance, claiming that her statement could bring instability to the Asia-Pacific region (Sukma, 2003).

However, the country continued with its critical stance toward the US and its allies. Indonesia stated that it remained committed to fight terrorism despite its strong disapproval of the use of military operations in any country (Azra, 2006) without the mandate of the UN. The Coordinating Minister for Political and Security Affairs, Yudhoyono, argued that the excessive use of military cooperation to combat terrorism would be counterproductive and could spark a clash of civilizations (Sukma, 2003).

The government's changing attitude generated a positive response from around the country. The chairman of Muhammadiyah, Syafii Ma'arif, for example, expressed his satisfaction and commended the government's steps, urging it to follow up with meaningful action. Meanwhile, hardliners hoped that Indonesia's position would be conveyed in an even stronger tone (Azra, 2006). Eventually, a stronger stance was expressed by both Foreign Minister Wirajuda in the commencement of the fasting month of Ramadhan in mid-November 2001, and President Megawati at the opening of the MPR Meeting. Megawati requested that the US halt bombing during Ramadhan and Christmas, expressing the necessity of a humanitarian ceasefire, and the need for a political settlement via diplomatic channels (Sukma, 2003). 
Meanwhile, Wirajuda emphasised the meaningfulness of Ramadhan for Muslims and the likelihood of an explosive response if military operations took place over Ramadhan (Azra, 2006). Both Megawati and her foreign minister made all indications that a prolonged and excessive military operation would not only be counterproductive but could also undermine the global coalition on the war on terror (Azra, 2006; Sukma, 2003).

Indonesia similarly articulated its position during international forums. In an APEC meeting in Shanghai, Indonesia requested that the UN take a pivotal role and initiate a collective response to fight global terrorism (Sukma, 2003). Indonesia also urged OIC member states to take similar stances to its own, namely the end of US military operations before the commencement of Ramadhan. Indonesia certainly appeared to take a firmer stance than other OIC member states, who merely expressed their concerns in relation to the military operation and urged the minimisation of innocent casualties (Azra, 2006).

The government's positive response to Muslim aspirations on this issue indicated its more accommodative policies when it came to Muslim issues. More accommodative foreign policies toward Muslim aspirations in the post Suharto era showed a shift from normally 'ambiguous' policies to 'unambiguous' ones (interview with Azyumardi Azra, 25/10/ 2013). Subsequently, Megawati seemed reluctant to fully participate in the global war on terror (A. Smith, 2010). The government did not wish to be seen as being pressured by Washington, as this would reflect negatively at home. Indonesia's reluctance could also be construed as a lack of enthusiasm in responding to the US's demands to freeze financial resources of suspected organisations that might have international terrorism connections (Sukma, 2003). Megawati's reluctance in fighting global terrorism was supported by Vice President Hamzah Haz and other key figures in the Megawati cabinet and the Indonesian military, who argued that international terrorism did not exist in Indonesia (A. Smith, 2003, p. 451). Megawati's reluctance to enter the global fight lasted for a year after the 9/11 attack. According to Murphy (2010), the Bali bombing was the turning point for Indonesia, which then brought about a firmer policy in relation to radicalism and terrorism.

\subsection{Domestic reaction to the Iraq war and the government's response}

In mid-2002 as public debate in Indonesia over the US military operation in Afghanistan dwindled (A. Smith, 2003), the US and its allies waged a war on Iraq to topple Saddam Hussein's regime. The US's pre-emptive strike in Iraq was generally condemned by 
Indonesians, especially Muslim groups, prompting anti-American demonstrations (Murphy, 2010). Two main factors that explain the strong condemnation are as follows; first, the unilateral acts of the US and its allies without the consent of the UN were thought to be arrogance on part of the US as the world's sole superpower, breaking norms of sovereignty, territoriality, and non-interference. Indonesia and several other ASEAN countries, particularly Malaysia, believed the military operation in Iraq could not be justified. Second, the US attack in Iraq reinforced the impression of a campaign against Islam, angering Muslims both in Indonesia and around the world. Using their dominant power, the US and its allies had arbitrarily invaded the Muslim country of Iraq. Like Osama bin Laden, Saddam Hussein was regarded by radical Muslim groups as a symbol of the fight against the dominance and arrogance of the US and other western countries.

There was a fear from more mainstream and moderate Muslim groups of NU and Muhammadiyah that the war allowed more radical groups to grow both domestically and internationally. The Iraq War, they argued, provided a medium for radicals to seize domestic politics at the expense of democracy, pluralism, and tolerance (Murphy, 2010, p. 372). In December 2002, the Coordinating Minister for Political and Security Affairs, Yudhoyono called for a peaceful solution to the Iraq crisis, arguing that the invasion of Iraq would bring about severe counteractions in Indonesia and indeed the world. Yudhoyono stressed Indonesia's position that the US should act in accordance with UN stipulations. Furthermore, it was said, unilateral action was not justified and would only result in harsh criticism from the government and the people of Indonesia (A. Smith, 2010, p. 146).

When the military operation against Iraq was launched on 20 March, 2003, both Indonesia's government and Muslim groups strongly condemned the unilateral actions of the US and its allies. Immediately after the war began, the Indonesian government issued a statement containing the following points. First there was Indonesia's strong condemnation of US military aggression in Iraq. Second, US unilateral aggression military was seen as going against UN rules, violating the mandate of the UN (A. Smith, 2010). Third, that military aggression was a threat towards world peace and security. The Indonesian government then called on the UNSC to carry out its mandate to ease the Iraq crisis (interview with Wirajuda, 18/12/ 2013). This statement echoed public sentiments throughout the country, as many segments of society strongly deplored US military action. 
At this stage, both the Indonesian government and Muslim groups held the same viewpoint in regards to the Iraq war. In line with Indonesia's increasingly democratised foreign policy, the likelihood of reaching a consensus between the government and the people remained open. At a Foreign Policy Breakfast in the end of 2002, a regular event at the Ministry of Foreign Affairs, the government and other foreign policy stakeholders jointly discussed a number of issues, including the Iraq crisis. With widespread public support, mainly from Muslim groups, the government was able to express its position firmly and confidently. When receiving a call from US Secretary of State Colin Powell seeking support for the military operation in Iraq, Wirajuda responded that the government had issued the aforesaid statement reflecting the voice and aspirations of both the government and Indonesian people. Colin Powell said, “I understand. Let's as democracies agree to disagree" (interview with Hassan Wirajuda, 18/12/ 2013).

It certainly appeared that the Indonesian government was well aware of the necessity of involving other stakeholders in foreign policy making. In the case of the Iraq War, the government was engaged in intense consultation with leaders of Muslim groups. This underlines the point made earlier, that despite its central role, the government is not the only actor in foreign policy decision-making in the post-Suharto era. In fact, involving other stakeholders has helped create a more solid and comprehensive foreign policy, and has given the government more confidence when dealing with countries like the United States.

\subsection{Reaction of Indonesian Muslims to the Danish caricatures}

Another issue that attracted the concern of Muslims in Indonesia, and indeed throughout the world, was the publication of caricatures of the Prophet Muhammad in the Danish Jylland Posten newspaper in September, 2005. Wider controversies followed in early 2006 when other Danish media published similar caricatures. Muslims denounced the physical illustration of Prophet Muhammad and the insulting nature of the drawings, (Daniels, 2007, p. 232) and called for a ban of such caricatures. The inability of the Danish government to properly respond to the issue exacerbated the controversy (Lindholm \& Olsson, 2011). What had initially been a domestic issue causing a relatively low level of debate, soon grew to global proportions, where it reached fever pitch (Lindekilde, 2009). 
The debate initially focused on the clash of free speech and religious sensitivity. On 25 October 2005, when 11 ambassadors from Muslim majority countries asked for a meeting with the Danish Prime Minister Anders Fogh Rasmussen, he declined, as he considered the request a form of foreign pressure. His rejection of dialogue with Muslim countries and the Community of Islamic Faith in Denmark indicated a government failing to read the sheer magnitude of the crisis (Lindholm \& Olsson, 2011, p. 260). The Danish government framed the situation as a matter of free speech, stating that any intervention was impossible. The government seemed to share the opinion of Jyllands-Posten's editor, Fleming Rose, and the Danish population, that Danish Muslims should integrate into Denmark's secular community, a community that respects freedom of speech. Furthermore, they argued, Muslims should not ask for special consideration in regard to "their religious feelings" (Powers, 2008, p. 343). However, for Danish Muslims the caricatures felt like discrimination (Lindholm \& Olsson, 2011). According to Hussain (2007) the controversy was the manifestation of "a century-long clash of misconception" (p. 113). This clash has consisted of (a) Muslim perceptions that Westerners have a different concept of 'profanity'; and (b) the perception that the West was engaging in a new Crusade against Islam. This was the result of the political situation in relation to the Israel-Palestine conflict, the Gulf War (1991), the Afghanistan War (2001) and the Iraq War (2003). It certainly appeared that both freedom of speech and religious sensitivities, as well the idea that the physical portrayal of the Prophet Muhmmad is not allowed in Islam, took second place in this controversy. In fact, the outrage among Muslims was more a reaction of "the discriminatory nature of the depiction" (Hussain, 2007, p. 115). Thus, the feeling of unequal treatment of Muslims was the primary factor that triggered protests across the globe.

As publications of the caricatures grew and anger rose toward the Danish government and their handling of the issue, OIC leaders met in Mecca, Saudi Arabia to address the issue (Powers, 2008, p. 344). Diplomatic relations between Denmark and Muslim countries, especially Egypt and other Middle Eastern states, grew strained. Even more insulting caricatures of the Prophet Muhammad were published, including one depicting Muhammad wearing a turban shaped as a bomb with a burning fuse. Many Muslims believed such images equated Islam, and its prophet, with terrorism. Subsequent condemnation and protests came from Muslims around the world, including Indonesia. 
This controversy thrust Denmark into a diplomatic crisis, described as the most severe for the country since World War II (Lindholm \& Olsson, 2011, p. 255).

In Indonesia there were both peaceful street demonstrations and violent demonstrations, and calls to cut diplomatic relations with Denmark. Militant groups including FPI, HTI, and Anti America and Israel Islamic Community (KUMAIL) protested for several weeks in the front of the Danish and US embassies and consulates, and staged both violent and peaceful actions. These groups mobilised thousands of demonstrators, and rejected the rather reluctant regret of Danish Prime Minister Anders Fogh Rasmussen. Both the Danish embassy and consulate were closed for a month in February 2006, over ongoing security concerns (Lie, 2008).

Meanwhile, moderate Muslims, NU and Muhammadiyah also denounced the Danish caricatures in public statements. Moderate Muslims generally did not partake in street demonstrations, and cautioned against overreaction. Instead, these organisations pushed the government to strongly criticise the publication of the caricatures. However, Muhammadiyah made the unusual move of suggesting that moderate Muslims boycott Danish products, a tactic that other Muslim countries had adopted. Typically, local and international media tended to broadcast the protests of militant groups, but ignored the voice of moderate Muslims in favour of "sensational images of violent extremists" (Daniels, 2007, p. 238).

The Liberal Islamic Network (JIL), a small group of Indonesian Islamic liberals, also responded to the issue. This group criticised the response of fellow Muslims, believing that their overreaction might provide a motive for racist, extreme right-wing groups in Europe to carry out unlawful acts toward European Muslims. This was not so much a clash of religious groups, but rather a clash of fundamentalist groups. JIL understood the honoured place of the Prophet Muhammad in Islam and of the sensitivity around insulting him. This group also acknowledged that the anger of Muslims was brought about by a sense of global injustice toward Muslims (Daniels, 2007, pp. 237-239). At the same time, PKS protested the caricatures in dialogues with Danish representatives, public statements, and peaceful street rallies. Anarchist actions were avoided, and the group sought apologies from both the Danish government and all European nations in which the caricatures were republished (Daniels, 2007). 
In response to the issue, the Indonesian government condemned the publication of the caricatures and tried to address Muslim aspirations. Even President Yudhoyono made public statements, including an article in the International Herald Tribune on 10 February, 2006, that denounced the publications for insulting the religious beliefs of Muslims. Yudhoyono stated that "reprinting the cartoons in order to make a point about free speech is an act of senseless brinkmanship. It is also a disservice to democracy. It sends a conflicting message to the Muslim community: that in a democracy, it is permissible to offend Islam" (Yudhoyono, 2006). He also questioned the tolerance of insulting Islam in liberal democracies and pointed to the emergence of Islamophobia in the West (Yudhoyono, 2006). In Indonesia, religious harmony trumps the importance of free speech (Daniels, 2007). But despite accommodating the concerns of Muslims, the government did not bow to pressure from certain radical groups to severe diplomatic relations with Denmark. In fact, the government deemed the apology from the Danish embassy in Jakarta suitably proper (Perwita, 2007).

\section{Toward a new Indonesian international identity}

\subsection{New international identity}

President Yudhoyono explicitly set out his view of Indonesia's international identity during his first foreign policy speech in 2005, stating that this identity should be reflected in its independent and active foreign policy. He argued that the identity "must be rooted in a strong sense of who we are" (Yudhoyono, 2005). Previously, Indonesia's international identity was well established as a natural leader of ASEAN, ASEAN's 'Big Brother', a Third World leader, and a NAM leader.

Yudhoyono's foreign policy speech illustrated the desire to transform the country's new international identity in line with the domestic political changes (Anwar, 2010a) of the post-Suharto era. The establishment of an international identity would reflect new elements of these domestic changes, chiefly the democratisation process and the increasing role of Islam in national politics. Yudhoyono affirmed that the country's international identity would reflect its position as the country with the largest Muslim population in the world, and as the world's third largest democracy. Although Islam was previously regarded as an enemy and a liability during the Suharto era, Islam is now considered an asset for national diplomacy by the Indonesian government. 
Indeed, the rise of Islamic political parties, Muslim groups and organisations, combined with the arrival of the democratic era allowing all segments of society to be involved in politics, has enabled Islam to be a core plank of national identity, placing it at the center of domestic politics. Consequently, this Islamic element has also shown itself in Indonesia's foreign policy. Indonesian diplomacy has attempted to portray Indonesia as a moderate Muslim country. Its relative success in achieving a consolidated democracy has given it confidence to exert greater influence in the regional and global arena (Sukma, 2012, p. 78).

\subsection{A new orientation}

The inclusion of Islam in foreign policy was inseparable from Indonesia's goal to restore the country's image after the occurrence of terrorist acts in the country. In the aftermath of the Bali bombings in October 2002, US officials named Southeast Asia, mainly Indonesia, as "the second front in the war on terror" (Murphy, 2009, p. 74). US Deputy Defense Secretary Paul Wolfowitz went as far as to state that Indonesia was a breeding ground for terrorists. His statement was perhaps based on evidence of a terrorist training camp in Sulawesi; the returning jihadis from Afghanistan; the rise of Islamic radical groups like Laskar Jihad and others; the horizontal conflicts in Ambon and Poso in South Sulawesi that pitted Muslim and Christian adherents against each other, and the conflict in West Kalimantan involving Madura and Dayak groups, together with Bugis people. At the time, such horizontal conflicts were wrongly portrayed as religious conflicts (interview with Umar Hadi, 25/09/2013).

The growing misperceptions between the West and Muslims were largely unavoidable in the aftermath of 9/11, the wars in Afghanistan and Iraq and the terrorist bombings in Southeast Asia. Bush's statement that the war on terror was not the same as a war on Muslims did not help matters a great deal. The Indonesian government had maintained a position right from the beginning that the terrorist acts had no relation with Islam. However, as mentioned earlier, hardline Indonesian Muslims believed that the US and its allies were waging war on Islam in the name of a global war on terror.

Suspicion as to United States motives significantly eroded after the Bali bombings. Prior to this, warnings from the United States of the possibility of a 9/11-style terrorist attack in Indonesia were met with scepticism. Megawati's vice president Hamzah Haz appeared to be one of these sceptics. Republika, a daily Muslim newspaper, had claimed that the US 
was in fact spreading 'information terror' amid its failure to validate its claims regarding the existing links between Indonesian radical Muslims and Al-Qaeda (Malley, 2002). Even Sholahuddin Wahid, a leader of NU and brother of Abdurrahman Wahid, stated that the US was carrying out "propaganda tricks" (A. Smith, 2003, p. 456).

The Bali bombings were followed by several other attacks, pushing Megawati to take decisive action against violent extremist groups. Moderate Muslim groups such as NU and Muhammadiyah supported Megawati's efforts in the fight against terrorism and in attempts to de-radicalise hard-line Muslims. Mainstream Muslim groups of NU and Muhammadiyah released a joint statement denouncing violence in the name of religion.

The Bali bombing was a turning point that empowered moderates, representing a triumph over radical groups that had dominated the public sphere in the post-Suharto era. Though small in numbers, the hard-liners were vocal and garnered a great deal of media attention. Despite their majority status, moderates did not typically articulate their concerns in an emotional way, earning them the moniker of 'silent majority'. With the rise of the use of social media, they have become ever more vocal and often confront hardliner groups on social media platforms and the internet. The government included them in Indonesia's public diplomacy activities. The country also started adopting the theme of 'empowering the moderates and strengthening their voice of moderation' in its public diplomacy. Through the Foreign Policy Breakfast, the government frequently sought their opinion and absorbed their aspirations so as to be included in Indonesia's diplomacy programmes. However, as radical groups often express their concerns publicly in the streets and beyond, they tend to dominate the media spotlight.

In addition to this, the government affirmed its position that terrorism had no relation with Islam. It also attempted to combat terrorism and restore Indonesia's negative international image. The country did not heed prior warnings from the US regarding potential terrorist attacks, and they faced the following challenges in the aftermath of the Bali bombings: First, there was no legal instrument that could be used to handle the problem, as the country had revoked its Anti-Subversive law. Hastily, the government introduced an AntiTerrorist decree known as Perpu No. 1/2002, enabling police to detain terrorist suspects. This was later replaced by Law No. 15/2003 on Combating Terrorist Acts. Foreign governments, particularly the US, pressured Indonesia to pass an anti-terrorist law, but both the government and the parliament had declined (Malley, 2002). Second, society 
lacked trust in the police and the country's intelligence agency. At this time, the Indonesian National Police had recently separated from the Indonesian National Military (TNI) to become an institution in its own right. Meanwhile, the National Intelligence Agency (BIN) was created, replacing the National Intelligence Coordinating Body (Badan Koordinasi Intelijen Nasional-BAKIN). BAKIN functioned differently from BIN, as it was merely a coordinating body overseeing various intelligence agencies within several institutions as well as in local governments. The government had to cope with such institutional challenges. Fourth, it was necessary to strike a delicate balance between a security approach and maintaining a newly established democracy when combating terrorism (interview with Umar Hadi, 25/09/2013).

In their decision-making process, the government considered the following aspects. First, it was in the national interest to maintain and promote the process of democratisation. Indonesia had resisted foreign pressure to pass an anti-subversive law like Singapore's Internal Security Act (ISA). If such a law were to be passed, it was feared it would hamper the democratisation process and incite a backlash from the population (interview with Umar Hadi, 25/09/2013). Second, taking into account the fact that Indonesia is a Muslim majority country, it was believed that the national interest lay in viewing terrorist threats in a 'proportional manner', whereby terrorism would be separated from Islam. The government worked to provide assurances that there was no relation between Islam and terrorist acts undertaken by extremist Muslims. The question instead was how Indonesia addressed the challenge of international terrorism within the democratic platform and its new democratic path. Third, from the outset Indonesia had stressed that the terrorist threat was an international security threat. As such, combating terrorism would require 'real' cooperation. Indonesia itself was a victim of terrorism as attacks on its soil were also carried out by Malaysians. Prior to the 9/11 attack, a Malaysian terrorist had detonated a bomb in Atrium, Jakarta in 2000. In sum, the 'shift' in Indonesia's priorities and approach within its foreign policy and diplomacy could be seen in relation to Islam, the democratic platform and international cooperation.

Indonesia's diplomatic strategy set out to (a) promote international cooperation in fighting terrorism, particularly in building the capacity of law enforcers and (b) encourage religious and cultural dialogue (interview with Hassan Wirajuda, 18/12/2013). Indonesia initiated the Bali Regional Conference on Counter Terrorism, as also known as the Bali Process. 
The initiative concluded with the establishment of the Jakarta Center for Law Enforcement (JCLEC) in Semarang, Central Java in 2004. The center now functions as a training center for law enforcement officers from across Southeast Asia. Meanwhile, as a response to international terrorism in the aftermath of 9/11 attacks, Indonesian diplomacy also promoted dialogue as a non-security approach to counter the common misperception in the West that Islam is associated with terrorism. Such dialogue was aimed at countering the so-called 'clash of civilizations' as depicted by Huntington (1996).

In fact, Western misperceptions toward Islam had developed long before the 9/11 attacks. The terrorist attacks of September 2001 had only confirmed them, predominantly the widespread idea that Islam is associated with violence, intolerance, and even terrorism. Immediately following the blast at the Alfred P. Murral Federal Building on April 19, 1995, most media hastily reported that the bombers were Islamist terrorists. However, the perpetrators were actually Timothy McVeigh and Terry Nichols, and this terrorist attack was the worst to occur on US soil prior to $9 / 11$.

When the 9/11 tragedy occurred, Indonesian foreign policy decision makers were concerned about the implications for Muslim countries like Indonesia. As a majority Muslim country, Indonesia would unavoidably bear a share of this existing misperception about Islam. However, the majority of Indonesian people believe that Islam is a peaceful, anti-violent, and tolerant religion. As Foreign Minister Wirajuda said, Indonesia had to issue a firm and clear statement in response to the 9/11 tragedy (interview with Hassan Wirajuda, 18/12/2013).

Faced with widespread misperception and the 'damaged image' of the country as a result of terrorist acts, the government of Indonesia hoped to promote religious and cultural dialogue as part of its public diplomacy. Adopting the theme of "empowering the moderates and strengthening their voice of moderation', the country sought to portray moderates as the true face of Indonesian Muslims to the international community. The success of combating terrorism in the long term will greatly depend on the empowerment of these Muslim moderates.

\subsection{New activism in Indonesia's foreign policy}

Religious and cultural dialogue has taken place since 2004 within the framework of bilateral, regional, and multilateral cooperation. Indonesia has conducted bilateral 
interfaith and cultural dialogues with 22 countries including the US, the United Kingdom, Germany, the Vatican, Italy, Pakistan, Argentina and Russia. An example of such initiatives is the establishment of the Indonesia-UK Islamic Advisory Council whose mission is to promote moderate Islam in both countries (Sukma, 2008).

In cooperation with Australia and Muhammadiyah, the Indonesian government initiated and hosted the first Asia-Pacific Interfaith Dialogue in Yogyakarta in 2004 under the theme 'Dialogue on interfaith Cooperation: Community Building and Harmony'. One of the stipulated agreements was the establishment of an International Centre for Religious and Cultural Cooperation in Yogyakarta. Subsequent dialogue was held in Cebu, the Philippines (2006), Waitangi, New Zealand (2007), and Phnom Penh, Cambodia (2008). Indonesia again hosted the sixth Regional Interfaith Dialogue in Semarang in 2012, and the Semarang Plan of Action was established. As part of these efforts, Indonesia established an Art and Cultural Scholarship for Future Faith Leaders and Media and Peace Journalism activities (interview with an official of MFA, 18/11/2013).

Interfaith dialogue has also been promoted through ASEM (Asia-European Meeting) and APEC. The first ASEM interfaith dialogue was held in Bali in 2005, under the theme of 'Building Interfaith Harmony within the International Community', and was co-sponsored by Indonesia, the UK, and the European Union. Subsequent ASEM dialogues were held in Larnaca, Cyprus (2006), Nanjing, China (2007), and The Hague, Holland (2008). Indonesia also initiated the APEC Intercultural and Faith Symposium: Building Mutual Trust and Acceptance for the Stability and Prosperity of the APEC Region in Yogyakarta in October 2006. The results of this dialogue were conveyed to the APEC Economies Leaders' Meeting (AELM) in Hanoi, Vietnam, in October 2006 (Rakhmawati, 2010). This has been accompanied by an interfaith and intercultural program involving youth from around the world, known as the Interfaith Youth Camp, first held in Surabaya in July 2008 (Rakhmawati, 2010).

Indonesia also actively participated in the UN Alliance of Civilizations (AOC), with the last meeting held in Vienna, Austria, in 2003. Indonesia hosted the UNAOC in Bali on 28202014 which was attended by 1480 participants from 98 countries and 23 international organisations. These organisations are members of the UNAOC's 'Group of Friends'. Indonesia views the UN AOC as a very important forum for inter-religious and cultural dialogue involving the government and civil society (Kemlu, 2015). According to a 
Foreign Ministry official, this dialogue has not involved militant Muslim groups. However, in a Cebu Interfaith Dialogue in 2006, the Ministry of Foreign Affairs invited a member of DPR, from the Islamist political party PKS, to attend the dialogue (interview with an official of MFA, 18/11/2013).

In addition to government-led interfaith and cultural dialogue, there has also been also a series of activities led by NU and Muhammadiyah. With the support of the government, NU initiated and hosted an International Conference of Islamic Scholars (ICIS), held in 2004, 2006, 2008, 2014 and the fifth in 2015. The ICIS is usually opened by the Indonesian president and attended by hundreds of people from more than 50 countries. Alongside Muslim clerics, Muslim scholars, Islamic studies scholars, and politicians, the ICIS also invited prominent world figures including the Prime Minister of Malaysia, who deliver keynote speeches.

With support from the government, Muhammadiyah established a World Peace Forum (WPF) which met for the first time in 2008 and most recently in 2015. The forum was intended as a space for world advocates to express their messages of peace and to shun violent means of settling conflict.

In response to the Danish caricatures and other similar incidents that emerged as a result of the existing misperception between the Muslim world and the West, Indonesia, in cooperation with Sweden, has held a series of meetings called the Global Inter-media Dialogue. The country has also actively taken part in similar dialogue within the Muslim world. For instance in 2011, Indonesia held the $2^{\text {nd }}$ International Conference on Islamic Media in Jakarta (interview with an official of MFA, 18/11/2013).

Both NU and Muhammadiyah have been actively involved in the peace process in Southeast Asia and beyond. Muhammadiyah has been involved in the Southern Philippines peace process between the Government of the Philippines (GPH) and the Moro Islamic Liberation Front (MILF). Muhammadiyah has been a member of the International Contact Group of the GPH and the MILF peace process. On the sidelines of the WPF, Muhammadiyah has also held the Special MNLF-MILF Dialogue Session promoting unity between conflicting Muslim parties of the Moro National Liberation Front (MNLF) and the MILF. Muhammadiyah has also played an important role in helping efforts to settle the conflict in southern Thailand by focusing on a capacity-building program for the Pattani 
people. Since 2008, around 300 Pattani students have been awarded scholarships to study at various universities managed by Muhammadiyah (interview with Dr Riefqi Muna, 2/12/2013).

NU has also played a role in the peace process in Afghanistan. It initiated a forum entitled "Role of Ulama (Muslim clerics) in Peace and Reconciliation of Afghanistan," involving dialogue and workshops. It has sought to facilitate the reconciliation of ulama (Muslim clerics) in Afghanistan. The forum was first held in Jakarta in 2011 and attended by Dr. Burhanuddin Rabbani, the Chairman of High Council of Afghanistan. On his suggestion, the second dialogue was held in Afghanistan and was attended by ulama from 12 provinces. NU has also granted scholarships to Afghan students to study in various universities that it manages (PBNU, 2013).

There are many other examples of the increasing engagement of Indonesian Muslim organisations in international diplomacy. After the concept of total diplomacy was embraced by the government, especially under the presidency of Megawati and in the first period of Yudhoyono's administration Indonesia encouraged some religious organisations, especially Muslim groups, to play a pivotal role and in many ways become the 'backbone' of the country's public diplomacy (interview with Maskuri Abdillah, 30/09/2013). Activities like those undertaken by NU and Muhammadiyah may also be understood as efforts to empower moderates in both domestic and foreign groupings.

A number of factors have seen a swell in Indonesia's confidence and a projection of its new international identity as the world's largest Muslim democratic country as well as an aspiration to become a "peace-maker, confidence-builder, problem-solver, bridge-builder" between the West and the Muslim world (Yudhoyono, 2005). These factors are as follows: (a) the relative success in fostering democracy in the world's largest Muslim country and managing the response of Indonesian Muslims to US military operations in Afghanistan and Iraq; (b) the ability to settle protracted secessionist conflict in Aceh and its experience as a peace facilitator in Cambodia and the southern Philippines (c) the appreciation of the West with regard to the success of the democratic process in Indonesia and its hopes that Indonesia could become a role model for other Muslim countries.

In strengthening its image as a moderate Muslim country and bridge-builder between the West and the Muslim World, and in addition to initiating and promoting interfaith and 
cultural dialogue, Indonesia has sought to play the role of peace-broker in settling conflict in the Muslim world. It initiated a meeting between Sunni and Shiah scholars from all over the world to find ways to solve sectarian conflict in Iraq. But the meeting was unsuccessful, largely because leading Iraqi and Iranian Shiah clerics refused to attend in protest at Indonesia's support of a resolution imposing sanctions against Iran (Murphy, 2009). Its involvement in the Annapolis conference in 2007 and its decision to dispatch a large contingent of UN peacekeepers to Lebanon is further indication of its desire to play this role (Sukma, 2008). Indonesia has promoted democracy to other Muslim countries, sending the message that democracy and modernity are not only possible but also expected (Sukma, 2011).

Indonesia has pursued its interest in including elements of democracy and human rights (including the rights of woman and good governance) in the new OIC charter. Indonesia was a strong advocate of the establishment of the OIC Independent Permanent Human Rights Commission (interview with Hassan Wirajuda, 18/12/2013). The commission held its first meeting in Jakarta in February 2012. The adoption of this new charter took place more than two years before the Arab Spring, and the discussion on democracy and human rights was quite progressive as no Arab countries had dared to promote those issues, as they were considered too sensitive.

Indonesia had also been encouraged by the West to get more involved in the Palestinian conflict. As a country viewed as 'moderate' by the West, Indonesia "felt pressure from the Western world to speak out against the more conservative strand of Islam" (Pitsuwan, 2012, pp. 348-349). Indonesian Islam is characterised by its ability to coexist with the values of democracy and modernity. One of the first to take note of the compatibility of Islam in Indonesia with democracy and modernity was Hillary Clinton, who said, "If you want to know if Islam, democracy, modernity and women's rights can coexist, go to Indonesia" (Landler, 2009).

Diplomacy programmes that emphasise Islam as an asset for soft power in diplomacy continued into the second term of Yudhoyono. However, there were no breakthroughs for the role of Indonesia in this regard. In fact, there is currently the impression that programmes and agendas that emphasise elements of Islam are in decline. There are several reasons for this. First, the idiosyncrasies of foreign policy actors, especially the 
Foreign Minister. Hassan Wirajuda (2002-2009) appears to have been more passionate about promoting moderate Islam and democratic values to other Muslim countries compared with his successor, Marty Natalegawa (2009-2014). Second, changing regional and international environments forced the government to set other agendas and priorities. The US global agenda shift from the global war on terror to other international priorities also impacted Indonesia's foreign policy interests. Indonesia has been concerned with the border conflict between Thailand and Cambodia and the contestation between major powers in the South China Sea, an issue that directly involves ASEAN countries. Great power rivalries have caused disunity between ASEAN members, especially when Cambodia assumed the chairmanship of ASEAN in 2012. Third, the public diplomacy objective of restoring Indonesia's negative image following the Bali terrorist attacks and the projection of Indonesia as a country for other Muslim nations to emulate has more or less been realised. Therefore, there is now a need to emphasise other foreign policy agendas and priorities that more aptly respond to regional and international realities.

However, with this 'shift in emphasis', many Indonesian Muslim figures, observers, and politicians have severely criticised the government for its unclear position on the issue of the Arab Spring. Intellectuals such as Azyumardi Azra and Rizal Sukma believe that in the face of changing regional and international contexts and strategies, the Indonesian government should continue to promote democracy and human rights (Alexandra \& Basuki, 2014), as well as continue its efforts as a role model for other Muslim nations. They argue these two aims should be embedded in the country's foreign policy, regardless of the domestic and international climate.

\subsection{The limits of Indonesia's international identity projection}

Whether or not Indonesia has succeeded in projecting its international identity has been subject to debate. As argued previously, the activism of Indonesia's foreign policy in relation to Islam was mainly driven by domestic politics but catalysed by international events. Its objective in protecting its international identity as a Muslim democratic country through interfaith and cultural dialogue and other initiatives was largely regarded as successful. What has been questioned, however, are its efforts toward the goal of becoming a peacemaker in the Muslim world, and a bridge-builder between the Muslim world and the West. 
Indonesia has faced a variety of challenges in reaching this goal. First, active Muslim militant groups, especially HTI and FPI, have frequently worked to undermine democracy in Indonesia. Their actions have raised questions over whether Islam, democracy, and modernity can develop together. Here, it is claimed that Indonesia, as a country where democracy, modernity, and Islam converge, should "establish an effective foreign policy that can have influence in the current global discourse between Islam and the West and within the Islamic world itself' (Anwar, 2010a, p. 52). It appears that the country's domestic political dynamic, which is sometimes coloured by conflict between radical Muslim groups and Christians (particularly in regard to the establishment of churches and attacks on Islamic minority sects like Ahmadiyah), does not support the image that Indonesia hopes to project to the outside world.

Second, Indonesia has limited influence within the Muslim World. Its role in the OIC has been marginal - the group is dominated by 22 Arab League members. Meanwhile, the most prominent member of the Arab League is Saudi Arabia, the biggest financial backer of the OIC. To some extent, Saudi Arabia has dominated the setting of the OIC agenda. Hassan Wirajuda described how the Arab League members presented a draft of the OIC statement for approval regarding the US intervention in Iraq as a result of their meeting with the wider OIC (interview with Hassan Wirajuda, 18/12/2013). This move caused discontent among non-Arab members including Indonesia, Turkey, Malaysia and Iran. They then established the Developing Eight (D-8), comprising eight OIC members: Bangladesh, Egypt, Indonesia, Iran, Malaysia, Nigeria, Pakistan and Turkey (Pitsuwan, 2012).

Third, the Arab world has often considered Islam in Indonesia as far from ideal. In their view, Indonesian Islam is influenced by local tradition and syncretism, and Indonesian Muslims are seen as "second class" Muslims (Murphy, 2009, p. 77). Fourth, the absence of diplomatic relations between Indonesia and Israel has dented Indonesia's willingness to get further involved in the Palestine-Israel conflict. Although Western countries have encouraged it to be more involved in Middle-Eastern conflicts, Indonesia has no diplomatic relations through which to engage Israel. Every effort to form relations with Israel, even formal trading relations, typically incites strong protest from Indonesian domestic constituents, similar to the events of the Abdurrahman Wahid administration. Finally, Indonesia has limited financial resources (Murphy, 2012) to support its policy of 
becoming a peace-maker and bridge-builder between the Muslim world and the West, as well as within the Muslim world itself.

\section{Conclusion}

Indonesia's foreign policy can be said to have a few clear characteristics in the postSuharto era. The impact of democratisation on the implementation of foreign policy, particularly in regard to decision making, has been somewhat different from previous eras. Foreign policy has not only been conducted in cooperation with a range of government actors, but also wider stakeholders including Muslim organisations. This represents a shift or even relaxation in the way Muslim aspirations have been treated in the post-Suharto era. It has become apparent that Islamic elements may be included in Indonesian foreign policy as long as they align with the core policy tenets of Pancasila as state identity, the 1945 Constitution, and the principles of an independent and active foreign policy. Indonesia's foreign policy is not to be based on religious principles, but rather should reflect national interests in general. Thus, the inclusion of Islam in Indonesia's foreign policy has not led to any dramatic foreign policy changes. Rather, the change that has occurred is recognition of the new aspirations of Muslims in the post-Suharto era.

It is important to differentiate between Islam as a political ideology and the political and social movements that influence Indonesia's foreign policy. As a political ideology, Islam is not found in any form in the country's foreign policy. Thus, we can conclude that Indonesia's foreign policy is not based exclusively on Islamic considerations. The country has also sought to avoid the expression of its foreign policy in terms of co-religionist solidarity. However, Islam does play a pivotal role in the social and political realm, and elements of Islam are apparent and embedded in the country's foreign policy as a result.

A crucial motivation for the use of Islam in Indonesian public diplomacy was to restore the country's international image in the aftermath of the Bali bombings and to rectify the misperception of the Muslim world in the West, particularly after the 9/11 tragedy. These two aims are the result of changing international politics in the aftermath of $9 / 11$, as it is believed that misperceptions will result in a disadvantageous situation for Indonesia as a Muslim majority country. However, the recognition of Islam as an important asset in public diplomacy was also be indirectly encouraged by the West, especially the United States, which expected Indonesia to be a role model for other Muslim countries due to its 
compatibility with democracy and modernity. With the West's encouragement, Indonesia has gained confidence in projecting a new international identity that emphasises Islam in its foreign policy. Clearly then, rather than merely arising out of domestic factors, the importance of Islam in Indonesia's foreign policy is driven by both domestic and international factors.

The emphasis of moderate Islam as the true face of Indonesian Islam may be interpreted as the triumph of moderate Muslim groups over more radical groups. Despite their small number, radical groups have more expressively voiced their concerns than the moderates. According to Anwar (2010b), the promotion of interfaith and cultural dialogues, which have become main aspects of Indonesia's recent public diplomacy, has been considered imperative in the efforts to overcome religious radicalism in the country.

Finally, the way Muslim groups in Indonesia influence foreign policy is in the form of pressure to the government on international issues related to Muslim causes. These pressures are generally reactive, and therefore the accommodation of such pressures by the government will also be reactive. Such accommodation usually does not lead to state activism manifested in programmes and activities within Indonesian foreign policy. The Indonesian government's responses to the Gulf War and US military operations in Afghanistan and Iraq are all forms of this reactive accommodation. However, in relation to terrorism and the global misperception of Islam, the government's adoption of Muslim aspirations has brought a sense of activism to its foreign policy. 


\section{CHAPTER FOUR \\ INDONESIA'S POLICY ON THE IRANIAN NUCLEAR PROGRAMME}

(2007-2008)

\section{Introduction}

Indonesia was elected as a non-permanent member of the UNSC for the period of 20072008. At that time, among the most pressing issues to be discussed was Iran's nuclear programme. The issue became the main agenda item after the International Atomic Energy Agency (IAEA) issued a resolution in September 2005 which handed over the case to the UNSC (Bahgat, 2007). As a non-permanent member of the UNSC, Indonesia was involved in drafting resolutions, including on the Iranian nuclear issues. UNSC resolution 1747which imposed sanctions on Iran - was unanimously adopted by all 15 members of the UNSC including Indonesia on 23 March 2006. The resolution contained several harsh measures, as Iran was believed not to be in compliance with the Non-Proliferation Treaty (NPT) to which the country is a party (Vermonte, 2014). At that time, Iran was allegedly seeking to develop nuclear technology for military purposes.

Indonesia's decision to vote in favour of resolution 1747 provoked considerable criticism within the country. Sanctions were viewed by many Indonesian Muslim groups as unfair treatment. They believed that the US had applied double standards in reinforcing the NPT regime, and that Iran was unfairly targeted in this regard. It was argued that Israel, for example, should also be treated the same. The two countries' different status in relation to the NPT (Israel was not a signatory) should not prevent fair treatment from being enforced. The issue became an 'Islamic issue' in Indonesia as it involved Iran, an Islamic state (Anwar, 2010b). Some Muslim groups thought that the treatment of Iran represented a war against the Muslim world (Anwar, 2010a).

NU and Muhammadiyah strongly protested against the decision made by the government. The government was accused of not being sensitive to the hearts of Muslims and of succumbing to the US and other Western countries' interests (Maghribi, 2007). Indonesia was seen as being steered by the US in the UNSC.

Although the Iranian issue itself was not related to religious issues, widespread rallies in Indonesia were inseparable from religious sentiments. The public perception, including that of Muslim groups, was also shared by many members of the DPR. Representatives 
from both Islamic political parties and nationalist parties objected to the government's support of the resolution. The disapproval eventually led parliament to demand the right of interpellation 6 to the government.

After voting in favour of UNSC resolution 1747, Indonesia abstained from voting on resolution 1803 on the extension of sanctions against Iran. This chapter will analyse the political background prompting the government to change its position from supporting sanctions on Iran to abstaining on the subsequent resolution. I argue that although the foreign policy making and implementation process was largely the domain of the government, domestic political forces, and in particular Muslim groups backed up by parliament, had a substantial influence on Indonesia's approach to the Iranian nuclear issue. I also argue that this substantial influence occurred as Muslim groups' aspirations and interests converged with other foreign policy stakeholders, mainly parliament. In this vein, Putnam's approach provides a framework for the international and domestic linkage, while Skidmore and Hudson's statist-pluralist approach highlights the need for the government in a democratic era to share its exclusive domain on foreign affairs with other stakeholders.

\section{The development of the Iranian nuclear programme}

Iran came under increasing scrutiny from the United States after the 9/11 terrorist attacks in 2001. The US named Iran as a member of the 'Axis of Evil' together with Iraq and North Korea. In this context, the Iranian nuclear issue became the subject of increased concern (Cordesman \& Al Rodhan, 2006). It seemed that a focus on Iran was more attractive to the US and other Western countries than a focus on North Korea. This

\footnotetext{
${ }^{6}$ According to Mochtar (2014), "interpellation in a presidential system [like in Indonesia] is used to request detailed elucidation of a policy, and only when the questioned policy meets the clauses for the removal of the president can the impeachment process be initiated". The right of interpellation can be forwarded to and executed in a plenary session if it is proposed at least by 13 members of DPR (interview with Abdillah Toha, 11/12/2013). The interpellation on Iran's nuclear programme - according to Abdillah Toha, a main sponsor of DPR's interpellation-aimed to rectify the perceived deviation/violation of the conduct of Indonesia's foreign policy. The government's decision regarding UNSC resolution 1747 had disregarded the spirit and principles of the 1945 Constitution, failed to channel the Indonesian people's aspirations, damaged national interest in the long run, and eliminated the opportunity of being an independent force in an effort to find a peaceful solution in the world, especially in the Middle-East. Using the right of interpellation, DPR asked for the government's explanations as follows. First, what was the basis of the government giving its approval to UNSC resolution 1747? Second, did the government's decision on supporting sanctions again Iran not contradict the 1945 Constitution, especially on articles relating to the rights to benefit science and technology for the people's welfare? Third, did the government not consider the resolutions a discriminatory and a form of double standard if considering that such a resolution is never applied to Israel - although it is a non-NPT party - that clearly has developed nuclear weapons? (DPR, 2007).
} 
emphasis on Iran became more substantial as the US linked it with Islamism and antiAmericanism in the restive region of the Middle East (Bonab, 2009).

The Iranian nuclear issue also gained attention in the mass media. $\mathrm{CNN}$, for example, reported on Iran's clandestine nuclear activities in Natanz in November 2002 (Bonab, 2009). The story began when an opposition group, the National Council of Resistance of Iran (NCRI), revealed a clandestine Iranian nuclear programme on 14 August 2002. This revelation strengthened the suspicion that Iran had been illegally developing its nuclear technology. The country had failed to disclose its main two nuclear activities: a uranium enrichment programme in Natanz and heavy water production in Arak (Bahgat, 2007, p. 6; Barzashka \& Oelrich, 2012; Schake, 2007). Iran was regarded as deceiving the IAEA for at least 18 years (Schake, 2007). The IAEA believed that in the period 1984-2002 Iran violated its obligations under the NPT Safeguard Agreements to inform the agency about its nuclear activities. The revelation of Iran's connection with A.Q. Khan, a Pakistani nuclear weapon expert, increased the list of its undeclared nuclear activities, namely acquisition of P2 centrifuge designs and components from Pakistan (Schake, 2007).

On 9 February 2002, President Mohammad Khatami welcomed the IAEA to inspect Iranian nuclear facilities, including Natanz. Three years of IAEA investigations from 2002 to 2005 did not reveal any certain conclusions. There was no assurance that the country's nuclear programme was for peaceful purposes, but nor was it clearly designed for nuclear weapon ambitions. The agency has not published evidence declaring nuclear material has been diverted for military purposes (Smith, 2011). However, there was evidence of uranium enrichment; the IAEA was not given all the necessary access to examine documents and to inspect dubious sites; and finally there was evidence of Iran's connection with A.Q. Khan (Barzashka \& Oelrich, 2012; Dewaele \& Pullinger, 2006; Schake, 2007).

The European Trio of the United Kingdom, France, and Germany (the so-called EU3) had made efforts to facilitate cooperation on Iran's nuclear issue. Their work produced the Tehran Declaration in October 2003. This agreement bound Iran to fully cooperate with the IAEA and to sign and implement the IAEA Additional Protocol (Dewaele \& Pullinger, 2006). However, Iran seemed reluctant to ratify the Additional Protocol. Tehran put restrictions on the IAEA's inspection of undeclared nuclear facilities and stated that 
inspection could be conducted only with prior agreement on limited terms (Cordesman \& Al Rodhan, 2006).

Another agreement was reached in November 2004, this time known as the Paris Agreement. This agreement was reached in the face of US threats to bring the case to the UNSC (Katzman, 2012). However, the agreement did not last long, and broke down after Ahmadinejad came to power in 2005. As Iran broke the IAEA's seals and continued its uranium enrichment at the Isfahan reactor on 8 August 2005, the agency board announced that the country had failed to comply with the NPT Safeguards Agreement. This was in relation to "the reporting of nuclear material, its processing and its use, as well as the declaration of facilities where such material had been processed and stored" (IAEA, 2005, p. 1).

In 2005 the confrontation between Iran and the US and some European countries entered a new stage. As a sequel to the agreement's failures, the IAEA Governor Board adopted a resolution bringing the case to the UNSC in February 2006 (Bahgat, 2007). However, some interesting events happened during the adoption of the resolution. The agency failed to reach a consensus, and the decision to bring the Iranian nuclear issue to the UNSC was made through majority voting. This showed that the response of the international community on Iran's nuclear programme was split (Bahgat, 2007).

In fact, Iran's nuclear programme would not have been possible were it not for the US and other Western countries' contributions (Bonab, 2009). Iran started developing its nuclear technology in the era of Shah with the support of the US and its allies. Beginning with the signing of a civil nuclear cooperation agreement with the United States in 1957 (Bahgat, 2007), Iran steadily built up its nuclear programme. Aside from the US, Iran was assisted by other Western countries such as West Germany and France (Takeyh, 2006). At that time, the US and European countries never questioned Iran's status as a rich oil country that might not need nuclear energy. Instead, they sold the nuclear technology for the construction of nuclear plants which could easily be converted for military means (Takeyh, 2006). On that basis, Iran signed the NPT in 1968 and ratified it in 1970 (Bahgat, 2007). The nuclear cooperation that created mutual benefits between Iran, the US and some European countries ended in 1979 with the removal of Shah. The establishment of the Islamic Republic of Iran marked the beginning of hostilities between the US and Iran. 
Since that time, successive US administrations have sought to prevent Iran from developing its nuclear technology. In the era of the Reagan administration, the US forged an agreement with its European allies to abandon their cooperation with Iran (Takeyh, 2006). Consequently, Iran turned to Russia and China as its partners in pursuing its nuclear programme in the 1990s. China lent its support for the Isfahan nuclear site and Russia secured a deal to complete the Busher reactor in the early 1990s and since then has refused US pressures to abandon the deal (Barzashka \& Oelrich, 2012).

Iran has appeared determined to achieve its ambitions in nuclear technology. Many aspects have been analysed to determine the country's motives on its nuclear programme. Some believe that Iran's behaviour was encouraged by its 'irrational' Islamic ideology. But this has been rebutted by scholars such as Takeyh (2006), Perthes (2010) and Davis et al. (2011). They view that Iran's nuclear programme was motivated by the country's national interests which are pragmatic in nature. Perceived threats from Iran's rivals in the region and from the US, coupled with its aspirations to become a regional power, are Iran's defined national interests. It is imperative to look at its nuclear motives from this perspective.

Historical records showed that aside from becoming a great power in the historic Persian Empire, Iran was invaded and supressed by foreign forces such as Arabs, the Mongols, the United Kingdom, and Russia. The United States also coloured the country's political life. The US supported the coup in 1953 to install the Shah's regime into power. Likewise, the US, most Arab states, and many other states supported Iraq during the Iran-Iraq war (Perthes, 2010). During the Iran-Iraq war from 1980-1989, when Iraq under Saddam Hussein used chemical and biological weapons against Iran, the international community was largely indifferent. This historical background contributed to the perception among Iranian elites that their country had been under constant threat. It also strengthened Iran's conviction that its national security should not be reliant on other countries nor the international community.

The combination of pragmatic interests (namely the need to survive in the face of external threats) and the feeling of national pride gives much impetus for Iran to persistently develop its nuclear technology (Baktiari, 2007). Despite its divided society, many Iranian people supported their government with regard to their country's nuclear issues (Bahgat, 
2007). If Iran continued to acquire nuclear weapons, these would likely be used as part of a deterrent strategy (Islam, 2010; Saikal, 2006; Sherrill, 2012). The state might also have learned from countries possessing nuclear weapons outside the P-5. North Korea, for example, has been able to utilise its nuclear capabilities to bargain its position vis-à-vis the US and its allies.

Besides Israel and the US, many analysts identify Iraq and Pakistan as potential threats to Iran (Bahgat, 2007). Takeyh (2006), for example, states that although Iran-Pakistan relations have been improved in the aftermath of 9/11, Iran has been worried about the instability of the Pakistani leadership. The fear of Pakistani radical Sunnis gaining power and access to nuclear weapons is something that creates anxiety among the Iranian elites. This feeling was the same when Pakistan conducted a nuclear test in 1998 (Takeyh, 2006). Thus, according to Dorraj (2006), Iran has not been able to settle the future spectre of a possibly hostile nuclear Pakistan. Yet it is hard to argue that Pakistan is a factor encouraging Iran to develop its nuclear technology. Despite their differences, the two countries have cooperated on the construction of a pipeline to ship natural gas from Iran to Pakistan and possibly to India (Bahgat, 2007).

There are different opinions as to whether Israel as a nuclear state has also pushed Iran to develop its nuclear weapons. Dueck and Takeyh (2007) and Takeyh (2006) argue that although there are hostile relations between Iran and Israel, it is difficult to conclude that Iran's motive to possess nuclear weapons is because of Israeli threats. Without disregarding the possibility of a direct military clash with Israel as suggested by some of Iran's rhetoric, both countries have carefully circumvented direct military confrontation. Meanwhile, other scholars such as Dorraj (2006) and Bahgat (2007) argue that Israeli threats backed up by the US, have been one of main elements encouraging Iran's nuclear programme. Israel is seen by Iranian clerics as a surrogate of the US in the region. Both the US and Israel are hostile to the Islamic movement and the Islamic Republic of Iran (Dorraj, 2006). In addition, Israel is a contender with Iran for regional power status. It is reasonable to consider Israel as an important element in Iran's geostrategic policy (Bonab, 2009, p. 168). 


\section{The Iranian nuclear issue in the UNSC}

Ahmadinejad's rise to power in 2005 was portrayed by the world as the rise of Iran's hardline assertiveness (Baktiari, 2007). It was anticipated that this would increase the difficulty of negotiations between Iran and the EU3. Iran violated the Paris Agreement by opening the IAEA's seal at Isfahan nuclear plant on 8 August 2005 and resuming uranium enrichment activities (Dewaele \& Pullinger, 2006). Responding to this matter, the IAEA issued a resolution on 24 September 2005. Due to its failure to reach a consensus, the decision was made through voting by 21 votes to one (Venezuela), with 12 abstentions including Russia and China. The resolution stating that Iran was in non-compliance with the NPT marked a new stage of handling the issue. It referred the case to the UNSC (Bahgat, 2007; Dewaele \& Pullinger, 2006).

The resolution did not, however, indicate a specific timeframe for the case to be brought to the UNSC (Bahgat, 2007). In fact, there was an opportunity for Iran to comply with the IAEA requirement before the agency reported it to the UNSC. After waiting for a few months, the IAEA concluded that Iran had not satisfied the agency. In early January 2006, Iran broke the IAEA seals at Natan nuclear enrichment plant, resuming its nuclear research programme which had been frozen for two years. Consequently, the IAEA Governing Board held an extraordinary meeting on February 2-4, 2006. The meeting decided to report Iran to the UNSC by 27 votes to three (Venezuela, Cuba, and Syria), with five abstentions including Indonesia (Dewaele \& Pullinger, 2006). Russia and China supported the resolution on the condition that it did not contain any clause stipulating immediate sanctions (Saikal, 2006). Enforcement of the resolution was postponed until the Director General of the IAEA delivered a report before the IAEA meeting in March 2006 (Dewaele \& Pullinger, 2006; Saikal, 2006). The IAEA officially reported Iran to the UNSC on 8 March 2006. This constituted a boost for the US and the EU3 (Saikal, 2006). In response, Iran suspended and did not ratify the Additional Protocol (Barzashka \& Oelrich, 2012) and declared the end of its suspension of full-scale uranium enrichment. At that time, Iran also threatened to withdraw from the NPT (Dewaele \& Pullinger, 2006). In April 2006, President Ahmadinejad announced that Iran had successfully enriched uranium at Natanz nuclear reactor to $3.5 \%$ of the fissile isotope, the low-enriched uranium appropriate for use in power stations (Delpech, 2007; B. Smith, 2011). 
Reporting Iran to the UNSC was intended to send a strong signal that the IAEA was not satisfied with Iran's position. This strategy was also designed to maintain pressure on the country (Dewaele \& Pullinger, 2006). Threatening Iran by reporting the case to the UNSC was the trump card played by the EU3 when dealing with Iranian negotiators prior to the Ahmadinejad administration. The Ahmadinejad administration, however, did not apparently care. The EU3 miscalculated in assuming that Iran was worried about its nuclear case being referred to the UNSC. In Iran there was a widespread belief that the pressure from the EU was unfair and that the IAEA was being bullied by the US (Ansari, 2007). Therefore, many Iranian people regarded the IAEA process as unreliable. Ahmadinejad said that Iran would never bow to pressure from the US and its allies and that Iran had survived US sanctions for more than 25 years. While criticising the referral of the Iranian nuclear issue to the UNSC, he called for complete disarmament and the establishment of a weapons of mass production (WMD) free zone in the Middle East (Saikal, 2006).

In March 2006 the UNSC issued a non-binding statement calling for the suspension of Iran's uranium enrichment within 30 days and the resumption of the talks (Bahgat, 2007). To further persuade Iran, in June 2006 P-5+Germany offered a package comprising both penalties and economic incentives to encourage the suspension of Iran's uranium enrichment. This reflected a unified position among the P-5, including Russia and China. More importantly, the US became involved in a direct negotiation with Iran for the first time since the 1979 Islamic Revolution (Bahgat, 2007; Spies, 2009). Unfortunately, the above strategy did not work. Neither incentives nor disciplinary approaches led to the intended goals.

Subsequently, the UNSC adopted resolution 1696 on 31 July 2006 demanding that Iran suspend all uranium enrichment and related activities within 30 days and cooperate with the IAEA. The resolution was issued under Article 40 of the UN Charter stipulating that compliance was mandatory. It was not passed under Article 41 on economic sanctions nor was it based on Article 42 authorising military action (Katzman, 2012). The resolution did not impose sanctions but if Iran did not comply further appropriate measures would follow (Starr, 2010). The willingness of the US to delete the reference to Article 42 led to the consensus among the P-5 (Nicolli \& Delaney, 2007). Iran responded by sending a proposal 
of engagement with the West (Katzman, 2012), but this proposal was regarded as vague and unhelpful.

Israel's attack on Hezbollah in Southern Lebanon in mid-July 2006 was expected to weaken the position of Iran due to the defeat of its main allies. However, the opposite occurred. Hezbollah emerged as a champion along with Iran as its main supporter. Predictably, this made Iran more confident to ignore the resolution (Nicolli \& Delaney, 2007). It allowed the deadline to pass by without any substantial action. As a result, the UNSC unanimously approved resolution 1737 imposing sanctions against Iran on 23 December 2006. The resolution was issued after considering the report of the IAEA Director General dated 31 August 2006. The report mentioned that Iran had not addressed the prominent problems of verification, had been not transparent with its nuclear activities nor had it halted its uranium enrichment activities. Iran had broken the provisions of the Additional Protocol (IAEA, 2006).

The resolution was adopted under Chapter 7, Article 41 of the UN Charter. It prohibited selling or financing technology that could contribute to Iran's uranium enrichment or heavy-water processing activities. It also urged states to freeze funds and other financial assets and economic resources of 10 named Iranian nuclear and missile companies and 12 persons related to the Iranian nuclear programme. However, as an interesting exception, the resolution was not applied to the Busher nuclear reactor (Katzman, 2012; UNSC, 2006).

Russia had objected to an earlier draft put forward by the EU3 which included a travel ban for those involved in the Iranian nuclear programme. Russia sought to water down the resolution, and instead of imposing punishment, Moscow's position was that the resolution should be designed to push Iran to the negotiating table. Moscow's overall relations with Iran and its strategic interests encouraged Russia to soften any attempt to impose harsh sanctions against Iran (Harvey \& Sabatini, 2010).

After Iran's refusal to temporarily suspend its uranium enrichment, the UNSC unanimously adopted resolution 1747 on 24 March 2007. Besides demanding the suspension of Iran's uranium activities by 24 May 2007, the resolution imposed additional sanctions (Katzman, 2012). This followed a report by the Director-General of the IAEA of 22 February 2007 which was unable to conclude that Iran's nuclear programme was for 
peaceful purposes (Gindarsah, 2012a). The continued programme of enriching uranium and constructing heavy water reactors was seen as an indication of Iran's disobedience.

This resolution imposed stricter sanctions against Iran. It included an arms embargo, restriction on states and international institutions making new commitments concerning grants, aid and loans (except for humanitarian and developmental purposes), and contained a request for the suspension of Iran's uranium enrichment within two months. The resolution also urged freezing assets of an additional 28 government officials, military, and institutions related to the Iranian nuclear programme. There was also a stipulation requiring states to report to the United Nations concerning the travel of those being sanctioned when entering their territories (UNSC, 2007b). Despite its noncompliance with resolution 1747, Iran did sign an agreement with the IAEA to settle prominent questions relating to its past nuclear activities by the end of 2007 (Katzman, 2012).

Subsequently, the UNSC issued the resolution 1803 on 3 March 2008 by 14-0 with Indonesia's abstention. This expanded the list of people and institutions covered by previous sanctions (Harvey \& Sabatini, 2010). It imposed a strict travel ban for 5 Iranians mentioned in Annex II and required travel reports of 13 persons named in Annex I. There was also an authorisation of inspections of shipments by Iran Air Cargo and the Islamic Republic of Iran Shipping Line, if the shipments were suspected to carry banned WMDrelated materials. The resolution also expressed the wish of the P5+1 to provide additional incentives to settle the problem through talks beyond those incentives given to Iran in June 2006 (Katzman, 2012; UNSC, 2008b).

Another resolution concerning the Iranian nuclear programme was unanimously approved on 27 September 2008. Resolution 1835 was a response to the IAEA's report of 15 September 2008. The agency stated that Iran had not stopped its uranium enrichment programme. No additional sanctions were imposed, but there was simply a demand for the state to comply with previous resolutions (Starr, 2010; UNSC, 2008c). Indonesia voted in favour of the resolution as it did not impose additional sanctions; and the country's proposed amendments were accommodated in a commitment to a negotiated solution as part of a 'dual track approach'7 (UNSC, 2008d). Russia also opposed additional sanctions

\footnotetext{
${ }^{7}$ It refers to "the moves after June 2006 to increase pressure on Iran were coupled by attempts of the permanent members of the Security Council plus Germany $(\mathrm{P} 5+1)$ to introduce Iran into negotiations by
} 
against Iran, partly because of tensions with the US and its allies in relation to the GeorgiaRussia conflict (Katzman, 2012).

China was also reluctant to impose additional sanctions. In spite of its concerns about the possibility of Iran acquiring a nuclear weapon, China had not seen Iran as a direct threat. China emphasised that there was more time left for diplomacy. Therefore, there was an accusation that China was more concerned with its commercial interests and energy needs than preventing Iran's nuclear activities. The country relies on Iran's energy supply. Around 15\% of China's oil comes from Iran (B. Smith, 2011).

UNSC resolutions 1696 (2006), 1737 (2006), 1747 (2007), 1803 (2008) and 1835 (2008) failed to stop Iran from developing its nuclear programme. Iran has insisted that it is pursuing nuclear technology for peaceful means. A more recent UNSC resolution 1929 was adopted on 9 June 2010, which placed substantial additional economic sanctions on banking and energy (Kenneth Katzman, 2015). However, this resolution only created a 'real' breakthrough once President Hassan Rouhani came into power in August 2013. Since that time, peace talks have progressed significantly and a Joint Comprehensive Plan of Action (JCPOA) was finalised in July 2015. The JCPOA is aimed at ensuring that Iran's nuclear programme is purely for peaceful purposes. This agreement replaced the Joint Plant of Action (JPA) interim nuclear deal which had been in force since January 2014 (Katzman \& Kerr, 2015).

\section{Indonesia and the UNSC on Iran's nuclear programme}

Weapons of mass destruction have become a concern in Indonesian diplomacy. Indonesia urges the implementation of all three pillars of the NPT. The Nuclear Weapon States (NWS) tend to emphasise the implementation of non-proliferation. They pay less attention to the pillars of disarmament and nuclear energy for peaceful purposes. Indonesia consistently views disarmament as imperative given that it could strengthen international peace and security (Parnohadiningrat, 2005). Indonesia supports the development of nuclear technology for peaceful purposes. The country's stance on on the Iranian nuclear issue has been in line with the above position. Indonesia supports Iran as long as it

offering it economic incentives in return for suspension of its 'proliferation sensitive' nuclear activities" (Spies, 2009). 
develops its nuclear technology for non-military goals. To that end, Indonesia has urged Iran to be transparent under IAEA inspection and verification.

Indonesia wanted the Iranian nuclear issue to be addressed peacefully through multilateral forums. A unilateral approach would not solve the problem. Continuous engagement involving the Middle Eastern countries and international society was important to create a WMD-free Middle East (Parnohadiningrat, 2005).

In the drafting of UNSC resolution 1747, Indonesia proposed some amendments to the initial draft sponsored by the $\mathrm{P}-5+1$. In its proposal, the country stressed the need to create a Middle East free from nuclear weapons and other WMD, rather than only mentioning Iran's nuclear threats. Indonesia's point in this matter was seemingly also directed at Israel which possesses nuclear weapons. It also urged that efforts be made to apply nonproliferation pillars in a fair and non-discriminatory manner. Therefore, the draft was expected not only to cover the recognition of rights of each NPT party to develop nuclear power for peaceful purposes, but also to remind all countries possessing nuclear weapons of their obligation to destroy their nuclear arsenals (BBC, 2007a). Indonesia also proposed an amendment affirming that all NPT parties, including Iran, have the right to develop nuclear technology for non-military means. Indonesia sought a reference to the necessity of lifting international sanctions against Iran should it meet with all the UNSC resolution's provisions (Kompas, 2007). The country also emphasised that any negotiations involving the Iranian nuclear stand-off should be based on good will to achieve a resolution acceptable to all parties (BBC, 2007a). One day before the voting on resolution 1747, Yudhoyono called South African President, Thabo Mbeki and the Iranian President, Mahmoud Ahmadinejad to try and find a viable solution. At a press conference Yudhoyono stated that

"We [Yudhoyono and Mbeki] expected Iran and the five permanent members of the Security Council to use the rest of the opportunity, no matter how small it is, to reach the best solution without imposing thorough sanctions which can create new problems. I also told President Mbeki that all members of the Security Council of the UN are given a chance to convey their views, so that whatever the decision [on the dispute solution], it will not be partial" (Xinhua, 2007a).

Meanwhile, when talking to Ahmadinejad, Yudhoyono expected a compromise that could lead to a good outcome for all parties (Xinhua, 2007a). After Indonesia's proposed 
amendments were accepted by other members of the UNSC, Indonesia decided to support resolution 1747.

Before becoming a UNSC non-permanent member, Indonesia had sought to reduce tensions around the Iranian nuclear issue. It believed that the existing dialogue mechanism which involved the EU-3 and Iran needed to be enlarged. The dialogue was supposed to include the UNSC non-permanent members and other developing countries in the NPT (Jakarta-Post, 2006a). Indonesia, as indicated by Yudhoyono, had showed its readiness to mediate the conflict. He was convinced that open conflict could be avoided through dialogue to find a peaceful and just solution (Collins, 2006). As a member of the IAEA Governors Board, Wirajuda visited Iran in January 2006, seeking a peaceful solution to the Iranian nuclear issue. Prior to the visit, he met the EU Foreign Policy Chief, Javier Solana. He called on the EU not to immediately bring the case to the UNSC (Xinhua, 2006a). At that time, Indonesia encouraged the EU and Iran to accept Russia's offer to have uranium enriched in Russia and insisted that the problem could be settled through reconciliation (Xinhua, 2006b).

When the Iranian nuclear issue was brought to the UNSC in early 2006, the Iranian Ambassador to Indonesia, Shaban Shahidi, met Yudhoyono and Wirajuda. Shahidi raised the inconsistency of the US and other Western countries towards Iran's nuclear programme. Iran was disappointed that the Western countries had brought the nuclear case to the UNSC without involving Iran in the meeting (Xinhua, 2006b). Meanwhile, Wirajuda said that Indonesia's position was consistent. It supported Iran's right to enrich uranium for peaceful purposes, but wanted Iran to cooperate with the IAEA to find a common solution (Jakarta-Post, 2006a). Indonesia took the position that the case should not be brought immediately to the UNSC (Xinhua, 2006a).

Indonesia's engagement on the issue might have come about out of fear of what the US and its allies did with Iraq. The US along with its allies invaded Iraq for the purpose of toppling Saddam Hussein's regime in 2003. Like Iran, Iraq's regime was accused of illegally possessing and developing weapons of mass destruction. Both Indonesian Muslim groups and the government of Indonesia feared that the US and its allies would launch a pre-emptive attack on Iran as it had been accused of illegally possessing nuclear weapons. Such worries were also expressed by Zulkifli Hassan, secretary general of the PAN, when 
saying: "I'm afraid it will end up like Iraq. The US was so convinced that Iraq had WMD but later it turned out to be an empty accusation. If Iran is cornered then we are worried they could retaliate" (Khalik, 2007b).

The negative impacts of ongoing problems regarding the Iranian nuclear situation also became a concern for Indonesia. Indonesia's still-recovering economy might be adversely affected if the Iranian nuclear crisis led to war. This notion was confirmed by Wirajuda, who said that "our involvement in seeking an amiable solution is not without sufficient grounds. If we do not do anything we are afraid the crisis will evolve into something that could disturb our economy" (Witular, 2006). At that time the price of crude oil reached USD 68/barrel, steadily rising to a record high in August 2005 of USD 70.85. If there was no immediate peaceful solution, it was predicted that the oil price would skyrocket to above USD 100. Iran produced about 4.2 million barrels/day (bpd) of oil and exported 2.7 million bpd, mainly to China, Japan, and the EU. Iran was the second largest producer of oil after Saudi Arabia in OPEC. Its oil reserves were estimated to reach 125.8 billion barrels which is approximately $10 \%$ of the world's total (Witular, 2006).

Indonesia took a cautious position. It attempted to demonstrate balance in its stance on the issue. Ahmadinejad's visit to Indonesia on 10-14 May 2006 was warmly welcomed by the government of Indonesia. His public speeches at the University of Indonesia and the Islamic State University of Syarif Hidayatullah in Jakarta received standing ovations. Undoubtedly his visit was to gain support from the Muslim people of Indonesia where Iran had not been depicted as a hostile country as it had been in Western states (Gee, 2006).

Throughout his visit, Ahmadinejad repeatedly said that the Iranian nuclear programme was only for peaceful purposes. The US and its allies liked to dominate nuclear technology and discourage the rest of the world from challenging that dominance. Iran, he said, had used its technology for useful purposes and "the welfare of the Muslim people around the world" (Gee, 2006, p. 38). His visit was successful in gaining significant sympathy among the Muslim Indonesian public (Hunter, 2010).

When receiving the Iranian Majelis Speaker Gholamali Haddad Adel on 16 February 2006, Yudhoyono stated a similar position to Ahmadinejad. The intervention of the big powers would raise problems for the Muslim world. He emphasised the salience of exchanging views between his country and Iran to resolve the existing problems of the Islamic world. 
His statement affirmed Indonesia's position on the right to use nuclear energy for peaceful purposes. Indonesia called for enhancement of nuclear cooperation with Iran within the framework of the IAEA. The president showed his country's willingness to benefit from Iran's experience in using nuclear technology for peaceful purposes (BBC, 2007b).

Indonesia maintained good bilateral relations with Iran. The two countries established a Bilateral Consultation Committee on Political Affairs on 9 May 2003 which conducted regular meetings. As developing countries, both states have showed a common interest in regional and international issues. Like Indonesia, Iran has taken part in international organisations such as NAM, OIC, and Development (D)-8. Their economic relations increased significantly. Trade accounted for US\$259.32 million in 2004; US\$368.76 million in 2005; US\$404.40 million in 2006; US\$553.09 million in 2007; and US\$975.31 million in 2008 (Kemlu, 2012a).

Indonesia's good relations and its relatively supportive position on Iran made the Indonesian public think that their government would vote on Iran's side. However, positive diplomatic relations did not appear to affect the government's decision in the UNSC. It supported the sanctions on Iran by voting in favor of resolution 1747. Clearly, the government of Indonesia misread the concerns of its public, especially Muslim groups, which had been demonstrated during Ahmadinejad's visit. That visit and the subsequent one from the speaker of the Iranian Parliament had considerably contributed to the pressure which came from Muslim groups and members of parliament when the government supported the UNSC resolution on sanctions against Iran later in March 2007. The government eventually had to face widespread criticism, especially from Muslim groups and members of parliament, in relation to that matter. Sensing Muslim groups' aspirations, members of parliament from both the DPR and Regional Representative Council (DPD) began to put pressure on the government.

\section{Indonesia's support for the sanctions on Iran and the domestic response}

The government's decision to support resolution 1747 was regarded by Muslim groups (which were butressed by many Indonesian politicians), as a blunder. The government seemed indifferent to public opinion. Dissident public sentiment came mainly from Muslim groups including moderate groups such as NU and Muhammadiyah and from Muslim militant groups such as HTI. Even Abu Bakar Baashir, an Indonesian radical 
Muslim cleric, showed his opposition against the Indonesian government's decision (Detik, 2007). Although Iran was regarded as being the home of a Shiah population, Muslim groups simply viewed Iran as a Muslim country that had been treated unfairly by Western states. According to the Pew Research Centre, $77 \%$ and $64 \%$ of Indonesians had a positive perception of Iran in 2006 and 2007 respectively (PRC, 2015).

Except PD, most political parties shared the public's views. Strong protests against the government came mainly from the Islamic political parties such as PKB, PAN and PKS. The sponsors of the interpellation rights were mainly members of Islamic political parties. The pressures that were started by Muslim groups continued in parliament. Muslim groups and DPR members appeared to mutually cooperate. Muslim groups got their aspirations channelled through politicians; meanwhile politicians utilised the momentum to discredit President Yudhoyono.

The government apparently did not anticipate that its decision would lead to significant domestic political upheaval. Yudhoyono confidently stated that resolution 1747 was intended to persuade Tehran to come to negotiations, not merely to impose sanctions. Sanctions were not the ultimate goal. The government's position was consistent in supporting the development of nuclear technology for peaceful purposes (Xinhua, 2007b).

Although pressure began to grow, the government was still unaware of the magnitude of the political consequences that might arise. This was reflected by Wirajuda's statement that the government would explain why it had supported the resolution. He considered that Muslim groups and the parliament had not been well informed and suggested that the resolution should be viewed comprehensively. It was a follow up to resolution 1737 asking Iran to stop its uranium enrichment. According to Wirajuda, in fact, Iran did not comply with the previous resolution (Xinhua, 2007b). Wirajuda stated that one reason why Indonesia supported the resolution was the change in Russia's and China's positions. Both countries had previously opposed the resolution, before eventually taking part in drafting it. The change in their position might be have been caused by their disappointment with Iran (NU-Online, 2007d).

Unprecedented protests against the government were sparked not long after the vote. Muslim groups expressed their strong disappointment with the government's decision. The protests were expressed in a variety of ways including making critical statements and 
opinions in mass media; street rallies; letters of protest addressed to concerned government institutions and media; and political manoeuvres in parliament.

Three different student organisations, namely HMI, KAMMI; and the Campus Dakwah Association, all rallied in Bogor, West Java on 3 April 2007. The rally denounced the government's decision at the UNSC and demanded the revocation of Indonesia's support of resolution 1747. They also urged the government not to bow to pressure from the US and the UN and said that Iran should be treated fairly with regard to the Iranian nuclear programme (Antara, 2007b). Earlier, the Forum of Islamic Ummah (FUI) and the AntiAmerican Intervention Front (FAIA) staged a rally in front of DPR, protesting the government's decision on Iranian sanctions. Some protesters were received by Vice Speakers of DPR, Soetardjo Soerjogoeritno and Zaenal Maarif, in their offices. While wearing masks of George W. Bush, the protestors carried a sheep and handed it to vicespeaker Soetarjo. The sheep symbolised Indonesia under the sling of the US in relation to Iran's nuclear programme (Gatra, 2007).

Meanwhile, HTI staged a rally in front of the UN office in Jakarta and issued a statement on its website condemning resolution 1747. HTI urged Muslims to question the moral integrity of the President of Indonesia who they said did not strive for Muslim causes (Gunadi, Febriana, \& Guritno, 2007; Yusanto, 2007). A street rally based on a similar concern was conducted by PPP and its affiliated organisations such as Angkatan Muda Ka`bah (Ka'bah Youth Association); Gerakan Pemuda Ka'bah (Ka'bah Youth Movement); Wanita Persatuan Pembangunan (Woman of United Development); and Generasi Muda Persatuan Indonesia (Young Generation of United Development) on 27 March 2007. These street rallies ended in front of the US Consulate General in Surabaya. While condemning the unfair treatment of Iran by the US and its allies, they also protested against the government support of resolution 1747 (Antara, 2007a). Meanwhile, Mahendradatta, a leading figure of the Muslim Lawyer Team, had called for support from Muslim groups including NU and Muhammadiyah for a proposed class action against the government. Mahendradatta believed that the government had violated Indonesian law. Among the initiators of the class action were Abu Bakar Baashir and Mashadi, head of the Forum of Islamic Ummah (FU)—a militant Muslim forum (Gunadi et al., 2007). 
In contrast, moderate Muslim groups such as NU and Muhammadiyah generally avoided mass protests. They criticised the government through the media and conducted 'political lobbies' towards the government and parliament. The Central Committee of NU strongly condemned the government's support of Resolution 1747. According to NU, the government's decision was a fatal mistake. Hasyim Muzadi, the NU chairman said that "Indonesia's decision to support the sanctions against Iran was a big blunder for the government" (NU-Online, 2007h). He argued that the decision would distance Indonesia from the Muslim ummah and other nations (NU-Online, 2007h). According to Muzadi, the government should be responsible to its people who are predominantly Muslims. Muzadi said that except for praise from the US, Indonesia did not gain any benefits from its decision (NU-Online, 2007j). NU supported the Iranian nuclear programme, arguing it was for peaceful purposes. It also expressed its concerns for other Middle Eastern states experiencing unjust treatment.

Meanwhile, NU's former chairman and the fourth Indonesian president, Abdurrahman Wahid also criticised the government's decision. He said it appeared that Indonesia had succumbed to its master, namely the US (NU-Online, 2007b). Sanctions against Iran would not improve the situation in the Middle East and settlement of the Iranian nuclear programme should be pushed through diplomatic channels. Abdurrahman Wahid said that it was foolish if Indonesia's support was based on the positions of Russia and China. (Surprisingly, given Wahid was widely known as being close to Israel and Jewish religious leaders, he was also very critical of Israel's nuclear programme) (NU-Online, 2007a). In the case of the Iranian nuclear issue, his stance was not different from NU. As the Head of the Advisory Board of PKB, he affirmed that the position of the PKB was the same as NU (Muhaj, 2007).

Muhammadiyah also echoed NU's position. When receiving the Iranian Ambassador, Behrooz Kamavandi, Muhammadiyah's chairman, Dr Din Syamsuddin, expressed the movement's regret about the passage of resolution 1747. Din said that the UN should respect the rights of Iran to develop its nuclear technology for peaceful purposes. As a Muslim majority country, Indonesia should show its sympathy and empathy for Iran, not to support resolutions against it (Suara-Merdeka, 2007a). The government's decision showed that the country only followed the interests of the major powers: a position that 
would only benefit Israel. There was no reason to object to Iran's nuclear programme for peaceful purposes (Khalik, 2007a).

The Executive Committee of the Muslimat of NU issued a recommendation rejecting the government's decision. The recommendation was a result of a national committee meeting on 29-31 March 2007. Its chairperson, Khofifah Indar Parawansa, stated that the resolution went against justice and humanity. She said that what transpired in the UNSC was discriminatory in letting Israel possess its nuclear weapons (NU-Online, 2007e, 2007k).

In this regard, the government seemed to be perceived as lacking caution in foreign policy decision making, mainly on issues related to Muslim concerns. Having been accustomed to being 'elite players' in foreign policy decision making, foreign affairs officials failed to understand Muslim groups' aspirations. Khofifah argued that "the feeling of most of the Muslim people was hurt by the government's careless decision by supporting the resolution against Iran. During his visit to Indonesia, Ahmadinejad, met the government and had a trilateral meeting between Ahmadinejad, the government, and religious leaders. We were convinced that his country's nuclear technology development was intended for peaceful purposes" (NU-Online, 2007e).

Muslim youth organisations expressed similar concerns. The Al Irsyad Youth, for example, strongly criticised the government's decision on the resolution. It said that the government succumbed to US pressure, despite Washington's discrimination in favour of Israel. The support for the sanctions on Iran injured Muslim solidarity and cooperation. More importantly, the resolution was specifically imposed on Iran, not on Israel. According to Al-Irsyad, the government and the rest of the world should not deny the rights of Iran to develop its nuclear programme for non-military means (Chalifah \& Alkatiri, 2007). The organisation also sent a letter of protest to the foreign minister, DPR, the Indonesian Mission to the UN in New York, the UNSC, and to mass media. More criticism came from the Youth Movement of Ansor and the Student Islamic Movement Association (PMII). They argued the government's decision had hurt Iran and injured the feelings of Indonesian Muslims (Edwin, 2007; NU-Online, 20071). Therefore, according to them, the government should be held responsible and needed to explain the decision in front of DPR (NU-Online, 2007e). 
Iran's Ambassador to Indonesia, Behrooz Kamalvandi, could not hide his disappointment with the Indonesian government's decision. He claimed that the inconsistency of the government's position had wounded Iran. Moral support from Muslim groups, by contrast, had raised Iranian morale in the face of the sanctions. Iran expressed its high appreciation to Muslim groups in Indonesia and the Iranian Ambassador met the NU and Muhammadiyah leaders at their offices (NU-Online, 2007c). Simultaneously, the US Embassy also approached the Islamic organisations, in particular NU. The approach was conducted even before the voting of the resolution on 23 March 2007. The US Chargé d'Affaires in Jakarta, John A. Heffren, met Hasyim Muzadi at NU's office on 21 March 2007. The US was concerned about NU's strong opposition to the sanctions against Iran. To encourage NU to adjust its stance, the US offered cooperation in the fields of education and management. However, NU did not appear to change its position. It stated that it did not support either the US or Iran and was concerned only about the possible injustice and the chance of an impending US military attack on Iran (NU-Online, 2007f).

Despite this criticism, the Indonesian government still seemed to underestimate the degree of discontent among Muslim groups backed up by many members of parliament. The Presidential Adviser for Foreign Affairs, Ali Alatas, for example, stated that there was public misunderstanding on the issue. The nuclear standoff, he said, should not be seen as a conflict between the Muslim and the Non-Muslim worlds. It was instead an issue of nuclear proliferation. With the resolution, Indonesia expected that all sides, especially Iran and the Big Five plus Germany, co-sponsoring the resolution, would still seek a peaceful solution through negotiations. Indonesia would have been consistent in its support of Iran if the country had been developing nuclear power for peaceful purposes, in line with the NPT (BBC, 2007).

Foreign Minister Wirajuda repeatedly explained the background of why the country supported resolution 1747. He said that Indonesia's support was based on a number of issues. First, Indonesia believed that the main aim of the resolution was to give priority to negotiations in the search for a peaceful solution to the problem. Second, most of the provisions in the resolution were consistent with Indonesia's position. The resolution provided the opportunity for Iran and Western countries to develop peaceful approaches. Third, the resolution was intended to send a strong message to Iran that all UNSC members unanimously voted to impose new sanctionsdue to its refusal to stop uranium 
enrichment. Fourth, during the drafting of the resolution Indonesia's proposed amendments has been accommodated (Khalik, 2007a; Wirajuda, 2007).

Prior to the voting, Wirajuda said that Indonesia had asked Iran to temporarily stop its uranium enrichment because it was a source of the West's suspicion. Hassan denied that Indonesia was under pressure from the US and other Western countries to vote in favour of the resolution (Khalik, 2007a). Muslim groups and members of parliament stated that US pressure had occurred when President Bush called President Yudhoyono, and when US Secretary of State Condoleezza Rice had called Yudhoyono and Wirajuda prior to the UNSC voting on resolution 1747. But Wirajuda argued that these calls were normal and did not mean pressure on Indonesia as the public believed. Indonesia was one of the few countries, he said, that could say no to the US. According to Wirajuda, Indonesia's firm position in response to international issues had received acknowledgement from Russia's Foreign Minister Sergey Lavrov who had said "to me, Indonesia is one the very countries that can say no" (interview with Hassan Wirajuda, 18/12/2013). In a number of meetings with Condoleezza Rice in Indonesia and the US, as well as in his meetings with Iran's Foreign Minister, Wirajuda always stressed a balanced approach. Indonesia supported Iran's nuclear programme for peaceful purposes and at the same time called on Iran to search for a peaceful solution and to cooperate with the IAEA (Jakarta-Post, 2006a).

Another explanation for the government's decision came from Presidential Spokesperson Dino Patti Djalal. He wrote an opinion piece for Kompas, the biggest daily newspaper in Indonesia, on 28 March 2007. His statement was considered insensitive and attracted a lot of criticism. He argued that Indonesia did not bow to any of the major powers, nor did it blindly defend Iran and make it Indonesia's master (Djalal, 2007b). Muslim groups viewed his statement as belittling those who were opposed to the government's decision. He implicitly stated that opponents of the government's decision made Iran their master. He indirectly accused NU and Muhammadiyah of being a kind of servant to Iran. Sihbudi (2007b) argued that Djalal's statement was humiliating and baseless. Both NU and Muhammadiyah clearly associated themselves with the Sunni Islam, and Sihbudi argued that it was impossible for the two Muslim organisations to have Shiah Iran as their master. Further, they said Indonesia's support for resolution 1747 could have been interpreted as its support directly or indirectly for President Bush to attack Iran (Sihbudi, 2007b). In an opinion piece for Tempo — a leading national weekly magazine—on 8 April 2007, Dino 
Patti Djalal explained the difficulties of Indonesia siding with Iran. First, Iran had broken previous resolutions 1696 and 1737 on its nuclear programme. Second, Iran had been regarded as uncooperative with the IAEA (Djalal, 2007a).

Muslim groups and members of parliament argued that the government had implemented an inconsistent policy on the Iranian nuclear issue (Hayid, 2007; Suara-Merdeka, 2007b). From their views in the mass media, Muslim groups had expected the government to oppose the resolution. The government's position was different from its approach shown during the visit of Ahmadinejad to Indonesia in May 2006 (Hunter, 2010). Muslim groups expected that the government would take a different position from the US and its allies in the UNSC as Indonesia had indicated by abstaining during the voting of the IAEA Governor Board meeting in February 2006. Muslim groups in Indonesia widely welcomed the government's abstention showing the government's disapproval of bringing the Iranian nuclear issue to the UNSC.

Muslim groups' views on the Iranian nuclear issue were confirmed by a survey conducted by Kompas in April 2007. More than half of respondents (50.4\%) disagreed with the government's decision. The survey also revealed that the level of disappointment of Muslim respondents was higher than non-Muslim respondents (Suryaningtyas, 2007). The government's argument that Indonesia's position in supporting UNSC resolution 1747 was based on the IAEA report and rational considerations of what had developed in the UNSC meeting was generally incongruent with public opinion. Most respondents (73.32\%) expressed the belief that international pressure had been a determining factor in the government's decision on that matter (Suryaningtyas, 2007). The government's statements that Indonesia's support for resolution 1747 was not greatly influenced by international pressure did not convince the Indonesian public. Surprisingly, Jusuf Kalla, the Indonesian vice-president in the periods of 2004-2008 and 2014-2019, acknowledged in an interview with the author that Indonesia had been pressured by the US. However, he did not mention the extent to which the pressure from the US had determined the government's decision to support sanctions on Iran (Jusuf Kalla, interview, 4/12/2013).

\section{Collaboration between Muslim groups and parliament}

The aspirations of Muslim groups were quickly taken up to by political parties. Muslim groups and political parties were concerted in expressing their regret and condemnation of 
the government's decision. This is interesting because the parties came from very different political platforms. That said, the main sponsors of Muslim views in the DPR were the Islamic political parties. They articulated the same concerns that Muslim groups had expressed. They condemned the government's submission to the US and other major powers. They accused the government of supporting discriminatory treatment and the double standard strategy of the US on the NPT (Suara-Merdeka, 2007a, 2007b). This objection came from members of parliament of both DPR and DPD. Theo Sambuaga, head of DPR's Commission I on Security and International Relations stated that "Indonesia should not accept the new resolution because it is not clear what Iran actually has violated, what is the basis for the US to accuse Iran of trying to build nuclear weapons" (Khalik, 2007b). Meanwhile a member of DPD, Marwan Batubara stated that "we regret the government's decision to support the UNSC resolution on sanctions against Iran. Such a decision reflects the weakness of independence of Indonesia in dealing with the US political agendas. Why did Iran receive a different treatment compared to US, Israel, India, North Korea and other Western countries?" (Shaleh, 2007). The different treatment of Iran and Israel by the US was repeatedly mentioned by politicians. They also pointed to injustice towards Iran as a Muslim country. They saw similiarities to what Iraq had experienced in 2003. Muslim groups and many members of parliament also felt that as a developing country, Iran had received unfair treatment from developed countries, in particular the US.

Among the most vocal politicians who repeatedly expressed their concerns about the government's decision was Effendi Choirie from the PKB. He stated that the government had failed as it supported a resolution that went against the 1945 Constitution, article 28 $\mathrm{C}(1)$. The article affirms the right to gain knowledge and technology for human welfare. Choirie further stated that "Indonesia lost its credibility in the eyes of third world countries. It failed to realise the country's efforts to become a mediator in the Middle-East conflict" (Suara-Merdeka, 2007b). The same concerns were conveyed by Ali Mokhtar Ngabalin, a legislator from the Crescent and Star Party (PBB). He said that the government's decision proved that Indonesia was still under pressure from the US. He stated that "It was useless to become a non-permanent seat of the UNSC if Indonesia was still under the pressure from the US. The government's decision did not constitute the representation (aspiration) of the Indonesian society" (Suara-Merdeka, 2007b). 
Meanwhile another member of DPR, Abdillah Thoha, and the vice-chairman of MPR, AM Fatwa, also strongly criticised the government. Both PAN politicians argued that Indonesia had succumbed to the imperialist countries led by the US to possibly invade Iran. Fatwa stated: "Why were we afraid of the US? Once again, Indonesia made a mistake on its foreign policy" (Suara-Merdeka, 2007b).

The vice-speaker of DPR, Muhaimin Iskandar, acknowledged his concerns about the inconsistencies of Indonesia's position. He claimed that in the beginning of the emergence of the Iranian nuclear issue, the government, the parliament, and the people of Indonesia had supported Iran in developing its nuclear technology for peaceful purposes. According to Iskandar, if the government suddenly changed its position, it showed inconsistency (Suara-Merdeka, 2007b).

The views of Muslim groups were not only taken up by the politicians from Islamic parties but also by politicians from non-Islamic parties such as Yuddy Chrisnandi from the Golkar Party and Sidharto Danusubroto from PDIP. They said that the sanctions that were imposed on Iran were inappropriate. Accusations about Iran's uranium enrichment had not been supported by adequate evidence. They argued that Indonesia should consistently support the Iranian nuclear programme as long as it was for peaceful purposes (Gindarsah, 2012a; Hayid, 2007). Yuddy Chrisnandi stated that Indonesia had betrayed its friendship with Iran. Meanwhile, the chairman of the PDIP faction in DPR, Tjahjo Kumolo, warned the President to be consistent with the independent and active principles of Indonesia's foreign policy (Harian-Terbit, 2007).

Not long after the UNSC vote in March 2007, there was a quick move by politicians in DPR to channel Muslim groups' aspirations in questioning and demand government accountability. On 24 March 2007, the First Commission summoned Foreign Minister Wirajuda. At that meeting, many members of DPR expressed their disappointment with the government. They argued that the resolution was not in line with the aspirations of the Indonesian people, in particular Muslim society. They said the Indonesian people supported the struggle of developing countries like Iran for justice including in developing nuclear technology for peaceful purposes. Second, resolution 1747 had put the emphasis on unfair sanctions rather than on solving a problem. It also created more tensions in the 
Middle-East, narrowed the dialogue, and opened the possibility for violating Iran's sovereignty (Rajagukguk, 2009).

The DPR also pursued the right of interpellation to the government. This was mainly sponsored by law makers from the Islamic political parties such as Effendy Choirie from PKB, Abdillah Toha from PAN, and other law makers from PBB and PKS. Some nonIslamic political party members in DPR such as PDIP and the Golkar party also became co-sponsors.

NU and the Youth Movement of Ansor strongly supported the right of interpellation. NU argued that the sanctions to force Iran to halt its uranium enrichment programme would not change the situation in the Middle East. The government's explanation that the sanctions were aimed at maintaining security and stability in the region was not persuasive (Nu-Online, 2007i). Meanwhile, Ansor regarded the interpellation as an opportunity for the government to explain the case to the people. This political statement was delivered during the $73^{\text {rd }}$ Anniversary of Ansor, which was attended by Vice-president Jusuf Kalla, prominent figure and senior politician of the PDIP, Taufiq Kiemas and the Minister for Cooperative and Small and Medium Enterprise who is also the chairman of PPP, Surya Dharma Ali. According to Ansor, the government's decision to support the resolution would jeopardise Iran and hurt the feelings of the Muslim world (Edwin, 2007).

It was not difficult to get the support from other members of DPR to realise parliament's interpellation. According to one report, within 20 minutes, 89 members of DPR had signed a petition for executing their interpellation rights to the government (Sihbudi, 2007b). In total 280 members of DPR from seven major factions, including Golkar and PDIP, supported interpellation. A report on the proposed interpellation rights of DPR was delivered by Abdillah Toha from PAN at the plenary session of DPR. The interpellation was eventually approved. The factions of PD and Partai Damai Sejahtera (the Welfare and Peaceful Party) voted against the interpellations and the faction of Partai Bintang Reformasi (the Reform Star Party), or PBR, abstained (Sijabat, 2007).

It is noteworthy that the case attracted the support of almost all factions in the DPR. Some parties such as PAN, PKB, PKS, and the Golkar party, which had joined the Democrat Party in a coalition to support the administration, also approved the interpellation. Their support of the interpellation demonstrated a 'fragile' governing coalition. A number of 
political observers argued the strong opposition among political parties to the government's decision on sanctions against Iran was related to dynamic domestic politics (Gindarsah, 2012a). The reduced cohesiveness of the governing coalition could be the manifestation of dissatisfaction among its members. The coalition supporting the Yudhoyono presidency consisted of the Democrat Party, the Golkar Party, and PPP, PKS, PBB. The coalition accounted for 414 seats (75\%) of a total of 550 seats in DPR (Gindarsah, 2012a). Surprisingly, the major proponents of the interpellation came from the governing coalition. Except for PD, all members of the coalition were sponsors of the interpellation.

On the day the interpellation was delivered by Abdillah Toha (15 May 2007), the Speaker of DPR, R. Agung Laksono from the Golkar Party, issued an approval letter to exercise DPR's interpellation rights and invite the president to give an explanation before DPR. The interpellation was conducted on 5 June 2007. However, rather than appearing in person, the president only sent six ministers and a senior official to answer the questions on his behalf. Of course, the answers from the government were similar to those expressed earlier by Wirajuda. The plenary session was flooded with interruptions protesting the absence of the president. The session was finally adjourned and rescheduled in order to convince the president to attend (Rajagukguk, 2009). However, the absence of the president did not violate the DPR's rules of proceedings (DPR, 2004).

NU's chairman Hasyim Muzadi said that the president should attend the interpellation. He stated that "the president should better attend it in order for the complicated problem to be more easily solved. Not like at present, the problem became complicated" (NU-Online, 2007g). However, he said that his statement was not intended to interfere with the government's approach (NU-Online, 2007g). Similar pressure came from the Islamic youth organisations such as PMII and Ansor. Both organisations asked the president to attend the interpellation, and argued that a direct explanation on the matter was necessary and the president should not be represented by his ministers (Edwin, 2007; NU-Online, 20071). The head of Ansor, Saifulloh Yusuf, stated that "Ansor expected the president would attend and explain its decision on the resolution 1747 to DPR. By doing so, the people would know why Indonesia supported the resolution" (Edwin, 2007). 
After failing to summon the President, the leaders of DPR held a Consultation Meeting (Bamus) between the government and DPR on 3 July 2007. This meeting was an attempt to break the political stand-off and meeting agreed on the following points. First, the government needed to consult with DPR on policies relating to highly sensitive issues for the people which had a major impact on foreign policy and international treaties. Second, the president stated that there was no intervention and pressure from the US with regard to the government's decision to support the resolution against Iran. Third, the president explained his foreign policy and the country's national interests. Fourth, the president still had not decided on attending to the plenary meeting discussing Iran's interpellation. He would wait for the results of the Bamus meeting which decided the schedule of the plenary session on Iran's interpellation (DPR, 2004; Rajagukguk, 2009).

The conduct of the right of interpellation was finally done on 17 July 2007 at the plenary session of DPR. Despite expectations and pressures from many sides, primarily Muslim groups, the president again did not attend the meeting. He assigned seven ministers to represent him in answering the questions from DPR. Despite many interruptions asking about the absence of the President, the meeting proceeded as scheduled. The government's explanation was presented by the Coordinating Minister for Politics, Laws, Defence, and Security, Widodo AS. In response, some factions from the caucus of political parties in the DPR understood and appreciated the efforts and decisions made by the government in relation to resolution 1747. However, most of the factions rejected the government's reasoning. The parliamentary parties argued that the problem could still be settled between Iran and the IAEA. The issue did not need to be discussed in the UNSC (Rajagukguk, 2009).

Despite dissatisfaction with the government's decision, the meeting agreed not to extend the interpellation to the legislature's 'angket' rights $^{8}$ as the government had understood the views presented during the interpellation. DPR emphasised that the government should have more consultations with the DPR before deciding its foreign policy in order to include the people's aspirations (Rajagukguk, 2009).

\footnotetext{
8 "The right to compel a person to attend a DPR meeting to provide information about a particular matter and to detain them for up to 15 days if they fail to comply" (Butt, 2015, p. 58)
} 


\section{The shift of Indonesia's position}

After 2007 Indonesia's policy shifted on the Iranian nuclear issue. It opted to abstain when the UNSC adopted resolution 1803 on 3 March, 2008, imposing additional sanctions against Iran. The country was alone in taking a different position from the other 14 members of the UNSC (UNSC, 2008b).

Muslim groups, members of parliament and the public at large including intellectuals responded to the decision with varying reactions. Political analyst Makmur Keliat said that abstention was the safest option for Indonesia. Meanwhile, Azyumardi Azra, a leading Islamic scholar, stated that abstention would come across as indecisive. He said that "we should have fully opposed the resolution if we are to comply with our soft-power foreign policy to uphold dialogue. Sanctions as we've seen, only groom radicalism" (Hotland, 2008). Muslim groups commonly welcomed the decision. Citing an unpublished poll, Gindarsah (2012b) revealed that $63 \%$ of respondents supported the government's decision to abstain on resolution $1803,35 \%$ disagreed, and $2 \%$ abstained. The government's decision was in line with a larger part of popular opinion, and that of Muslim groups.

Many sides argued that the shift of the government's position was because of public pressure. A researcher from LIPI (Indonesian Institute of Sciences) and a Muhammadiyah activist, Dr Riefqi Muna, believes that the shift of the government's position on resolution 1803 was because of pressure from society, especially Muslim groups and parliament. Indonesian foreign policy makers had used a rational choice approach by considering international and domestic factors to come to the abstention position (interview, 2/12/2013). According to Vermonte (2014), all the political dynamics which had ocurred in and outside of parliament "led the government to adjust its position over the Iranian crisis" (p. 213). In this regard, the pressure and influence of Muslim groups which were supported by the parliament encroached on the government's domain on a technical aspect of foreign policy making, affecting whether or not Indonesia supported UNSC resolutions (interview with Dewi Fortuna Anwar, 20/11/2013). Since that time there was an indication that the government seemed to be more cautious and had changed the way foreign policy was to be formulated. The government increasingly involved the wider community in discussing Indonesia's foreign policy issues, especially concerned members of the public. The shift in the government's decision on resolution 1803 might be seen through this lens (interview with Abdillah Toha, 11/12/2013). 
However, perhaps not surprisingly, the government was reluctant to acknowledge public pressure as a factor contributing to the change in Indonesian policy. Wirajuda said the decision was taken after considering the IAEA report in February 2008. According to the report, Iran had been willing to cooperate with the IAEA in making its nuclear plans transparent and compliant with the rules of the IAEA (Gindarsah, 2012a). The government saw positive developments on the Iranian side, and regarded further sanctions against Iran as unnecessary. Likewise, the Indonesian Representative to the UN, Ambassador Marty Natalegawa, said that "the IAEA-Iran Work Plan was a platform to restore the confidence of the international community" (Hotland, 2008).

Yudhoyono also rejected the idea that the shift was related to domestic pressure or external interests. The government had independently decided its policy he asserted. Presidential spokesman Dino Patti Djalal said the abstention vote was not designed to avoid the recurrence of the interpellation move of the DPR nor harsh public pressure. He said that "since the inception, we had viewed that this...was [a] technical matter, not politics. We did not want this problem to be politicized because this issue was potentially prone to be politicized" (Okezone, 2008).

The government's argument that it ignored pressure from Muslim groups and members of parliament seems implausible. Yudhoyono needed their support in running his government as well as retaining power. He likely calculated all political consequences if he did ignore Muslim groups' aspirations. Pragmatically, Yudhoyono would not have wanted to lose support from Muslim groups in the 2009 election. The fact that almost all members of the governing coalation supported the right of interpellation might have given more push for Yudhoyono to change the position of the government when it came to resolution 1803. The shift of the government's position according to Abdillah Toha was not separated from domestic pressure (interview, 13/12/2013). The decision to abstain was taken to avoid further protests from Muslim groups and members of parliament including Yudhoyono's coalition partners, when seeking his re-election in 2009 (Gindarsah, 2012a).

Whatever the government's motives, the decision to abstain was welcomed by DPR. Indonesia had not followed the US and had shown progressive diplomatic endeavour to implement its independent and active principles of foreign policy (Rajagukguk, 2009). The main sponsor of the interpellation, Abdillah Toha, said that "we saw there was progress on 
the government decision where Indonesia was the only country to abstain on the Resolution 1803. Despite the strong external pressure, Indonesia still opted to abstain. We could regard it as an achievement for us" (Okezone, 2008). Other non-permament members of the UNSC, namely Vietnam, South Africa, and Libya, also experienced strong external pressure in the UNSC to support the resolution. The three countries eventually succumbed to external pressure (Okezone, 2008).

A different voice was put forward by Effendy Choirie, a legislator from PKB. He regretted the government's decision and suggested Indonesia should have taken a stronger stance. The abstention position on resolution 1803 reflected indecisive diplomacy. Such a decision demonstrated that the country's president and foreign minister were indecisive leaders (Okezone, 2008).

The government apparently tried to strike a balance between domestic politics and the US and its allies' interests within the UNSC. Earlier, pursuing domestic political reconciliation and trying to avoid unnecessary domestic upheavals, Indonesia objected to a UNSC statement condemning Iranian President Ahmadinejad's call for wiping Israel off the map (Gindarsah, 2012a). The country also opted to vote to abstain at an emergency session of the UNGA on a draft resolution putting little pressure on Israel over its action in Gaza (Gindarsah, 2012a). In the aftermath of the domestic upheavals due to the government's decision on resolution 1747, the Ministry of Foreign Affairs conducted additional closed breakfast meetings on foreign policy. The meetings were attended by concerned groups, especially Muslim group leaders and members of DPR (Rajagukguk, 2009).

To further repair the damage in domestic politics and 'restore' Indonesia's diplomatic relations with Iran, Yudhoyono visited Iran in March 2008. He was received by Mahmoud Ahmadinejad and the Supreme Leader, Ayatollah Seyyed Ali Khameini, as a brother. Both countries agreed to cooperate in a number of areas. They agreed to build a USD $\$ 6$ billion refinery in Banten and forged a commitment to supply 150,000 barrels of crude oil for the plant. Indonesian companies were also invited to participate in Iran's upstream oil industry. As expected, Indonesia's abstention generated a positive response from Iran (Jakarta-Post, 2008a). Prior to President Yudhoyono's visit to Iran, the President sent his Special Envoy for Middle Eastern Affairs, Dr Alwi Shihab to Iran on 18-19 June 2007 to explain Indonesia's decision on the resolution 1747. All these efforts might be viewed as 
an effort to 'repair' Indonesia's bilateral relations with Iran as well as to demonstrate the government's willingness to accommodate public opinion on the Iranian nuclear issue.

\section{Conclusion}

It is undeniable that Islam was an important factor that influenced the shift of the Indonesian government's decision on the Iranian nuclear issue. The Yudhoyono administration had an interest in improving its image among Indonesian Muslims.

Since the beginning of the democratic era, Muslim groups have positioned themselves as among the influential forces in Indonesian politics and in foreign policy, especially on sensitive issues related to Muslim concerns. Pressure from Muslim groups was channelled through political parties and politicians in the DPR and greatly contributed to the change of Indonesia's foreign policy in the case of the Iranian nuclear issue. Pressure from Muslim groups was quickly embraced by pragmatic politicians. The interests of Muslim groups and members of parliament converged to pressure the government. This combination of interests made the pressure effective. The government's change of heart in the UNSC on the Iranian nuclear issue was apparently driven by domestic pressure, despite officials' denials. Abstention was a reasonable option for Indonesia. Although there were harsh critics from Muslim organisations and the public at large, the government apparently still cautiously considered the external pressure of the US and its allies in the UNSC.

The government seemed to misread public options when deciding to vote in favour of resolution 1747. The government's denial of Muslim groups' pressure was upheld to show that the goverment was the only legitimate agent in deciding and implementing foreign policy. Indeed, the goverment has remained the key player in foreign policy making and implementation. However, this case suggests political forces outside the goverment have gained a more substantial influence on the country's foreign policy. The influence of Islam has become more important when Muslim aspirations coincide with the interests of politicians in parliament.

It is rare that religious groups and politicians are in concert in Indonesia. This might be the first time the government has faced such a united movement. Muslim groups and members of parliament shared a view that the Yudhoyono government had betrayed Iran. Muslim groups demanded that the government should accommodate their concerns about the 
West's unfair treatment of Iran. The phenomena of Muslim groups' pressures can be considered normal. The growing importance of Islam in Indonesia's foreign policy coincided with the rise of Muslim groups and the establishment of Islamic political parties in the post-Suharto era. The influence of Islam on the country's foreign policy became more noticeable on sensitive issues related to Muslim concerns. Indonesian Muslims became more concerned when the 'Islamic issues' related to Israel and to some extent, the US. The concern that the US would attack Iran as it had Iraq doubled the pressure on the Indonesian government. At that time, Muslim groups believed that the government had given the US and its allies the opportunity to invade Iran. A possible attack on Iran was one of the main explanations as to why the public, especially Muslim groups, regarded the government as having made a blunder when supporting the sanctions on Iran. Despite the government's denials, the Iranian nuclear issue suggests that Muslim groups did play a crucial role in shaping a key foreign policy decision. 


\section{CHAPTER FIVE \\ INDONESIA'S POLICY TOWARDS KOSOVO'S INDEPENDENCE: PREEMINENT NATIONAL INTEREST}

\section{Introduction}

Kosovo's unilateral declaration of independence on 17 February 2008 was met with a range of international responses (Boulton \& Visoka, 2010). These can be categorised into countries that have either recognised, objected, or stayed silent on Kosovo's declaration of independence (Almqvist, 2009). Russia and China spearheaded the non-recognising countries, opposing the US and major EU countries such as the UK, France, and Germany which all sponsored Kosovo's independence. However, the Council of the European Union has left the matter up to each member state to take a position on whether or not to recognise Kosovo (Duic, 2009). Having no common foreign policy, the EU could create no single position. While the majority of members of the EU supported Kosovo's independence, some members did not recognise it. Cyprus, Romania, Slovakia, and Spain are among the countries that did not recognise Kosovo's unilateral independence declaration.

The advisory opinion of the International Court of Justice (ICJ) on Kosovo in July 2010 stipulating that the unilateral declaration did not violate international law has not eliminated the debate on the status of Kosovo (Wolff \& Rodt, 2013). Debate on Kosovo's self-determination, secession and statehood have all continued (Pippan, 2010). Despite disputes surrounding Kosovo's legality, the number of countries that recognise Kosovo has increased over time (Kosovothanksyou, 2015). Indonesia is one of the non-recognising states. This policy has been questioned by Muslim groups and members of parliament. Proponents of recognition believe that there is no reason for the government to not recognise Kosovo. In spite of suggestions and pressures from Muslim groups, especially Muhammadiyah, the Indonesian government has remained firm on its position. The fear of repercussions from separatist movements in Indonesia is widely believed to be behind the country's policy towards Kosovo. This chapter argues that Muslim groups' aspirations were less effective in this case as they confronted the 'perceived fundamental national interest' in relation to national territorial integrity. Despite strong pressures from Muslim groups, especially Muhammadiyah, the Indonesian government did not entertain their 
pressures to recognise Kosovo's independence. The consideration of maintaining territorial integrity is paramount to Indonesia's strategic national interests.

This chapter discusses the Indonesian government's response to Muslim groups' aspirations regarding the recognition of Kosovo's independence. It will also discuss the extent to which the government has accommodated the concerns of these groups. Also highlighted is the debate on the status of Kosovo's self determination, secession, and statehood. This case will show the shortfalls in Putnam's approach on the need for the government to set a balance between domestic and international pressures and interests. Instead potential international pressure converged with already existing domestic pressure for Indonesia to recognise Kosovo's independence but were still unable to change the position of the government of Indonesia.

\section{The status of Kosovo's independence}

Kosovo's declaration of independence on 17 February 2008 prompted diverse reactions from other states. Since the 1999 NATO campaign (Fierstein, 2008) the international community has been deeply divided and Kosovo's declaration only deepened these divisions. This was reflected by the failure of both the European Union and the UNSC to come up with a common position on whether to condemn or to approve Kosovo's independence (Almqvist, 2009, p. 1). The EU took a pragmatic approach, letting its member states make a decision on whether to recognise Kosovo according to their respective national policies and interests (Duic, 2009, p. 166).

As is widely known, Kosovo's conflict has seen a debate between state sovereignty and territorial integrity on the one hand, and a people's self determination and independence on the other hand. The unilateral declaration of independence has added further legal complexity (Muharremi, 2008), including raising the legal principles of territorial integrity, self-determination, state sovereignty and state recognition (Fierstein, 2008). The declaration of has sparked controversy over the legality of Kosovo's statehood (Jaber, 2010). International law has not given clear guidelines or stipulations as to how Kosovo's situation might be addressed (Cerone, 2009). Instead, the case has demonstrated the phenomenon in which national political interests have influenced international law (Borgen, 2008b). Therefore, writers such as Hilpold (2009), Jia (2009) and Pippan (2010) suggest that scholars of international law should find a new approach to settle problems 
like Kosovo due to the unavailability of international legal principles that fit with actual reality.

Kosovo's unilateral declaration of independence (UDI) established two opposing sides with regard to the legality of its statehood, namely recognising and opposing states. In fact, there is another category of states outside those two groups, namely silent states which do not show a clear position on Kosovo's independence.

States that recognise Kosovo's independence have defended their positions by putting an emphasis on political aspects and generally have avoided going into detail regarding aspects of international law. The prospect of peace and security in the Balkan region following Kosovan independence has been a prominent concern in their statements of recognition (Almqvist, 2009). They believe Kosovo's independence would promote and create stability in the region. They see Kosovo as a sui generis case, not constituting a precedent for other cases (Bardos, 2008; Visoka \& Bolton, 2011). Further, recognising states justify their support for Kosovo's independence based on a number of factors, inter alia: gross human rights violations under Serbia's President Milosevic; a decade of supervised international administration; the exhaustion of Kosovo's final status negotiations; Kosovo's acceptance of 'international supervised independence'; and Kosovo's assurance to promote minority rights (Visoka \& Bolton, 2011, p. 2). States such as Costa Rica, Columbia, Ireland, Estonia, and the US made a special reference in their statements to the 1999 UNSC resolution 1244, the 1999 Rambouillet Accords, and the 2007 Marti Ahtisaari Plan (Almqvist, 2009).

In contrast, the majority of opposing states have based their objections on international law, especially the UN Charter on the principle of territorial integrity, and UNSC resolution 1244 (1999) (Almqvist, 2009). Opponents, including Russia, China, Spain, Romania, Vietnam and South Africa, found that Kosovo's unilateral declaration was inconsistent with resolution 1244. They viewed Kosovo's UDI as illegal, a violation of Serbia's territorial integrity and the delineation of Kosovo's international borders without the consent of Serbia (Visoka \& Bolton, 2011). Aside from legal concerns, opposing states also have used political concerns such as the argument that Kosovo's independence could create a dangerous precedent (Almqvist, 2009) by setting a legal validation for secessionist movements around the world to unilaterally declare independence, which may lead to 
international instability. International law does not allow self determination outside the colonial context. According to these opposing states, in the absence of a parent state's consent, the unilateral secession should be illegal and would create a negative precedent for other regions around the world (Visoka \& Bolton, 2011).

As Kosovo's parent state, Serbia steadfastly sought to have Kosovo remain part of its territory. Immediately after the UDI, Serbia, together with Russia, demanded an emergency meeting of the UNSC on 17 February 2008. This was the first time in several months that the UNSC would publicly talk about the Kosovo problem (Duic, 2009; Weller, 2008). Serbia's diplomatic initiative initially seemed successful. Russia's veto along with China thwarted the endorsement of Kosovo's independence by the UNSC (Jamar \& Vigness, 2010). Besides China and Russia, other UNSC members at the time, namely Vietnam, South Africa, and Indonesia also indicated their opposition to Kosovo's independence. While Vietnam and South Africa stressed the clash of Kosovo's independence with resolution 1244, Indonesia expressed its concern that negotiations had not yet been exhausted (Weller, 2008).

Although the majority of EU member states have recognised Kosovo, there are seven EU states that have refused to do so. Most of the seven non-recognising EU states including Cyprus, Romania, Slovakia, and Spain, have faced secessionist problems (Bardos, 2008). Undoubtedly Serbia's strongest ally is Russia. Aside from its contestation with the US concerning Kosovo's fate, Russia's opposition to Kosovo's independence was caused by its concerns over Chechnya. Kosovo's case has potentially brought about a greater threat of secession in Chechnya. However, paradoxically, Kosovo's case had been used as a primary justification for Russia's interference in Georgia and support for South Ossetia and Abkhazia (Jamar \& Vigness, 2010), and later on Crimea and eastern Ukraine. China's non-recognition of Kosovo is in line with its position on domestic non-interference principles. With regard to domestic concerns, China has faced secessionist movements in Tibet and Xinjiang Autonomous Region. China's troubled relationship with Taiwan also contributed to its firm position with regard to separatism. Any success of separatist movements in another country is viewed by China as a threat to its own sovereignty and territorial integrity (Jamar \& Vigness, 2010). 
On the other hand, the US and major Western European states supported Kosovo's independence even before it was declared (Vidmar, 2009). Those states argued that any delay in approving Kosovo's status as an independent state could be calamitous for peace and security in the region (Ker-Lindsay, 2009). Supporting states described Kosovo as a sui generis case that had its own unique characteristics (Warbrick, 2008; Weller, 2008). These are related to the context of the collapse of the Federal Republic of Yugoslavia (FRY) and the mismanagement of the conflict in its aftermath (Abazi, 2008). From this point of view, the Kosovo case does not constitute a precedent for other unresolved ethnic conflicts. This argument is based inter alia, on the violent nature of the FYR's break-up, serious human rights violations, international supervision and administration which prevented Serbia from having effective control over Kosovo since 1999, and the persistent impasse in negotiations between Pristina and Belgrade (Nevo, 2009).

Furthermore, UN resolution 1244 internationalised the problem, noting that secessionist problems are primarily an issue of domestic law (Borgen, 2008b). The following official statement of US Secretary of State Condoleezza Rice, as quoted by Patterson and Mason (2007), sums up the majority of Western countries in seeing the Kosovo case as sui generis: "The unusual combination of factors in the Kosovo situation-including the context of Yugoslavia's break-up, the history of ethnic cleansing and crimes against civilians in Kosovo, and the extended period of the UN administration - are not found elsewhere and therefore make a special case. Kosovo cannot be seen as a precedent for any other situation in the world today" (p. 97). Meanwhile, on 18 February 2008, the EU issued the following statement as quoted by Patterson and Mason (2007): "Kosovo constitutes a sui generis case which does not call into question these principles and resolution" (p. 97). However, not long after, Russia treated Kosovo as a precedent by supporting the independence of Abkhazia and South Ossetia from Georgia (Nevo, 2009).

Although supporting states avoided references to self-determination, their arguments inherently implied remedial-self determination when they cited the impossible human rights situation facing Kosovo under Serbia's rule. Instead, their argument has been made in conjunction with references to the principles of effectiveness where for many years Serbia and Kosovo had been governed in total separation (Muharremi, 2008; Pippan, 2010). On the other hand, past human rights concerns did not directly lead to the right to secession but constructed "an effective situation that ultimately legitimized secession" 
(Vidmar, 2009, p. 837). Such an argument has been put forward by Orakhelashvili (2008), who states that 'factual effectiveness never creates legal positions on its own, but only coupled with agreement and consent between states" (p. 9).

In line with this, Serbia and Russia argued that without the Serbian consent, resolution 1244 would not allow Kosovo's independence based on the resolution's preambular paragraph: "Reaffirming the commitment of all member states to the sovereignty and territorial integrity of the Federal Republic of Yugoslavia”. However, the EU argued that resolution 1244 neither promotes nor prevents Kosovo's independence. The references to Serbia's territorial integrity are "silent as to what form the final status of Kosovo takes" (Borgen, 2008a, p. 462)

On 22 July 2010, the ICJ gave its advisory opinion with regard to the legality of Kosovo's independence. This opinion was in response to the UN General Assembly (UNGA) resolution on $8^{\text {th }}$ October 2008 questioning: "Is the unilateral declaration of independence by the Provisional Institute of Self-Government of Kosovo in accordance with International Law?" (Nevo, 2009, p. 99). The adoption of this resolution was considered a victory for Serbia's diplomacy which had managed to secure support in the UNGA for that purpose (Pippan, 2010). However the ICJ did not issue the advisory opinion expected by Serbia (Falk, 2011). Instead, the advisory opinion said Kosovo's declaration did not breach international law (Wolff \& Rodt, 2013). Neither objecting nor supporting states gained much from the ICJ advisory opinion (Hannum, 2011), which settled only a few of the legal questions related to the situation surrounding Kosovo's independence (Muharremi, 2010). However, the influence of the ICJ's advisory opinion could not be disregarded "in the course of negotiations, with the international society being more supportive of Kosovo's status as an independent state" which in turn increased the pressure on Serbia (Öcal \& Çelenk, 2010, p. 180).

The barriers to realising self-determination in relation to Kosovo's unilateral declaration of independence do not seem as high as previously considered. This can be seen in the increasing number of recognising states following the ICJ advisory opinion (Wolff \& Rodt, 2013). Although the legality of Kosovo's independence remains contested under international law, as of the May 20, 2015, Kosovo has been recognised by 111 out of 193 UN member states (Kosovothanksyou, 2015). 
Kosovo still faces challenges in gaining recognition from states, regionally and globally. Recognition is mainly a political not a legal act. Therefore, political recognition is a unique action by a given state. Intergovernmental organisations do not automatically lead their members to common positions on unilateral declarations. Therefore, we see divided positions among EU members, OIC states, and even the members of ASEAN.

\section{Muslim countries' reactions}

As has been the case in other international organisations, the OIC has not united around one position on Kosovo's independence. Only 34 out of 57 (60\%) of OIC member states have recognised Kosovo. The organisation lets its member states decide based on their national policies and interests (Chickrie, 2009).

Kosovo believes the OIC has a strategic role. As the second largest multilateral organisation after the UN, the OIC is deemed important for Kosovo to expand and enhance its international standing (MFA-KS, 2014). Since 1996, the OIC Secretariat has supported Kosovo's right to independence (Al-Hamid \& Naffee, 2012). Further, the support which has been granted by OIC Secretary General, Ekmeleddin Ihsanoglu, following Kosovo's UDI, shows that the organisation has given importance to the recognition of Kosovo. The OIC's support was further demonstrated with the visit of Ihsanoglu to Kosovo on 1-3 May 2013 (TodaysZaman, 2013).

Despite being a secular country and having a Western political orientation (Krasniqi, 2011), Kosovo seems unable to override its demographic structure which is around $90 \%$ Muslim. In this case, religious affinity among Muslim states seems to have become a salient factor. Kosovan Prime Minister Hashim Tachi said that his country's policies have been in conformity with Muslim countries' general political stances. He emphasised that "Kosovo is determined to further strengthen its ties with the OIC in the next phase" (AlHamid \& Naffee, 2012). Yet Kosovo's aspiration to become a member of the OIC has been hampered by the OIC membership criteria which requires that every applicant state (candidate) should first be a member of the UN (Al-Hamid \& Naffee, 2012).

The OIC is rather unique as an international organisation compared to other regional and international organisations. Unlike the ASEAN Secretariat, for example, the OIC Secretariat has more power and authority. To some extent, the OIC Secretariat enjoys a 
considerable role, authority and power vis-à-vis the OIC member states. Therefore, Kosovo is not misguided when frequently approaching the OIC Secretariat in seeking recognition of its independence. The succession of the OIC Secretary General from Ekmeleddin Ihsanoglu (of Turkey) to Iyad Madani (Saudi Arabia) has not apparently changed the support of Kosovo by the OIC secretariat. This was indicated by Iyad Madani's statement that: "We strongly believe that Kosovo should be an independent state. Our role in the OIC is to encourage more member states to recognize Kosovo. As Secretary General, I do not see any reason for any of the member states not to recognize Kosovo" (MFA-KS, 2014).

In spite of relentless support by the OIC Secretariat, OIC member states are still divided with regard to the recognition of Kosovo. However, it is worth noting that among the earliest countries recognising Kosovo's independence were some OIC member states, namely Afghanistan, Albania and Turkey on 18 February 2008 as well as Senegal on 19 February 2008.

Turkey actively encouraged other countries, in particular the OIC states and the Arab League member states, to recognise Kosovo's independence (Albeu, 2011). There were a number of reasons why: first, it was deemed necessary to have the final status of Kosovo confirmed so as to create a lasting peace in the Balkans. Second, so long as there was no decisive final status and the process remained open-ended, the state-building reforms required by the international community could not be effectively conducted by Kosovo Albanians (Eralp, 2010). Turkey's position toward Kosovo may be regarded as controversial considering that it has also faced the Kurdish secessionist movement. However, Turkey's view on the uniqueness of the Kosovo case and its conviction that the independence of Kosovo would promote peace and stability in the Balkan region led the country to take such a stance (Eralp, 2010).

Turkey's decision to recognise Kosovo led to negative relations with Serbia, yet the relationship quickly recovered. The rapprochement between the two countries began with the visit of President Abdullah Gül to Belgrade in October 2009, where the two countries agreed to disagree on Kosovo. Serbia also pragmatically applied this position toward all countries recognising Kosovo's independence (Bechev, 2012). 
Besides playing an intermediary role in prompting more African countries to recognise Kosovo (Delisio, 2013), Turkey has seemingly become the most prominent country in the OIC to encourage other member states to recognise Kosovo's independence. At the OIC Summit in Dakkar in 2008, Turkey made significant efforts to have a strongly worded statement leading to the OIC's support of Kosovo. However, some OIC member countries such as Egypt, Indonesia, Sudan, and Azerbaijan strongly opposed the issuance of such a statement in the OIC Final Communiqué. As a result, the OIC only expressed its solidarity with the Kosovar people without lending clear support to Kosovo's independence and without encouraging other OIC member states to recognise that independence (TodaysZaman, 2008).

Kosovo has utilised religious solidarity in its diplomatic approach toward Muslim countries. Religion and particularly Islamic identity have constituted central factors in shaping public opinion. Arab governments may have felt considerable pressure from their people to recognise Kosovo (Nassar, 2008). Kosovo has hoped that Arab countries might take the lead among states to recognise its independence. To that end, Kosovo conducted the Kosovo and Arab World Conference on 25 ${ }^{\text {th }}$ August 2008 (Foniqi-Kabashi, 2008). Kosovo has also enjoyed support from the Arab League. The Secretary General of the Arab League, Nabil Al-Araby stated that "the Arab League is determined to support the principle of self-determination, as part of the UN Charter, emphasising that Kosovo's cause is supported by the Arab League Organization” (MFA-KS, 2013). At present, all Gulf Cooperation Council (GCC) countries and other major Arab countries such as Libya and Egypt have recognised Kosovo's independence (Kosovothanksyou, 2015).

Compared to Libya and Egypt, Saudi Arabia was much quicker in recognising Kosovo, a step which it took in April 2009. It is not difficult to understand Saudi Arabia's position. As a staunch ally of the US in the Middle East, Saudi Arabia has often followed US policies. The country tabled a draft calling for recognition of Kosovo at the OIC Ministerial Meeting in Damascus, Syria, in May 2009, and demanded that the 57 OIC member states immediately recognise Kosovo in the name of Muslim brotherhood. However, Saudi Arabia's manoeuvre was strongly opposed by Iran, Syria, Algeria and Egypt. The amendments in the resolution removing any call to recognise Kosovo indicated the failure of Saudi Arabia as a proponent of Kosovo's independence (b92, 2009). Yet Saudi Arabia has helped and supported Kosovars since the Kosovan conflict by assisting 
refugees in the entire Kosovo region. In the post-war era, Saudi Arabia lent its substantial assistance to rebuilding schools, healthcare centres and mosques which were destroyed during the war. During his visit to Riyadh in June 2012, Prime Minister Thaci managed to secure Saudi Arabian financial assistance to develop his country's roads, education and other fields (kryeministri-ks, 2012).

Libya and Egypt's long standing relations with Yugoslavia and domestic political situations may have delayed their recognition of Kosovo (Cigar \& Clawson, 1999). During NATO's strikes, Libya and Serbia were steadfastly committed to maintaining their trade and economic relations. Serbians had been involved in running Libyan industry and their officers had also turned their hand to training Gaddafi's personal guards (Schwartz, 2002). Traditionally under Qaddafi and Saddam Hussein, Libya and Iraq had interests in the decline of US presence and influence, including in the Middle-East (Cigar \& Clawson, 1999). The position of Libya and Iraq on the role of the US in NATO's response to the Kosovan crisis should be seen through this lens. Therefore, any attempts by Kosovar delegations to have Libya abandon its pro-Serbian stance were ignored during the Gaddafi era (The-Economist, 2011). Libya believed that the UNSC was the only viable place to find a comprehensive solution acceptable to all. As a non-permanent member of the UNSC in 2008-2009, Libya had consistently called on all parties to maintain communication channels and dialogue to solve the differences between Serbia and Pristina (UNSC, 2008a)

Egypt did not immediately recognise Kosovo following the steps of the US and the EU. It argued that the issues of independence and recognition should be addressed by all involved parties in the UNSC. Along with Iran, Syria, Algeria and Azerbaijan, Egypt once again opposed an OIC resolution on Kosovo which called for Kosovo's recognition in May 2009 in Syria. Eventually, the resolution only welcomed the developments made during the first year of Kosovo's independence, without actually calling for its independence (Chickrie, 2009).

Recognition from both Egypt and Libya came only after the Arab Spring hit these two countries and changed their respective regimes. Egypt recognized Kosovo's independence in June 2013. Meanwhile, Libya's recognition was made on September 25, 2013, after a meeting between Libyan Prime Minister Ali Zidan and Kosovo's Prime Minister Hashim Tachi on the sidelines of the 68th UNGA in New York (Mzioudet, 2013). 
As opposed to Libya and Egypt which shifted their policies towards Kosovo in the aftermath of regime change, another important member of the OIC, namely Iran, has continued with its non-recognition of Kosovo's independence. Here it is interesting to look at Iran's early reaction to the Kosovo crisis prior to NATO's air strikes. When Serbia made initial moves against Albanian Kosovo in early 1998, the Iranian media systematically and continuously urged its country to cooperate with the West in seeking a resolution to the Kosovo conflict (Cigar \& Clawson, 1999). However, this situation was totally changed in the aftermath of the Rambouillet Agreement in February 1999. The Iranian media urged that the Kosovo conflict be resolved through UN channels, and condemned any actions by NATO as inappropriate or unacceptable. When NATO's air strikes commenced, Iran immediately took a position similar to Russia and China, blaming NATO for its illegal actions and condemning them as violating international law (Cigar \& Clawson, 1999).

Anti-American sentiments and suspicions, especially during the Ahmadinejad administration, have been deeply entrenched in Iranian public opinion. Iranian leaders continue to consider the US and its allies as a threat to their regime and its national interests. The US military presence in the Middle East, the perceived US interest in Iranian regime change, and its support for Sunni Middle-Eastern countries and Israel have nurtured Iran's threat perception towards the US and its allies (Kenneth Katzman, 2015). Iran's rivalries with other countries identified as US allies in the Middle East continue to strengthen its relations with Russia. All these political realities have directly and indirectly influenced Iran's non-recognition policy towards Kosovo's independence (Hafezi \& Wroughton, 2015).

\section{Indonesia and the Kosovo issue}

Indonesian Muslim groups have, generally speaking, harboured fewer concerns about Kosovo compared to their interest in Bosnia, even when the Kosovo crisis reached its peak in the 1990s. The Kosovo issue might reasonably be expected to command the same attention among Indonesian Muslim groups as the Bosnian plight, as both suffered the effects of ethnic cleansing (Sihbudi, 2001a).

What made a difference between Kosovo and Bosnia according to Indonesian Muslim groups was first that the West was more responsive to the Kosovo crisis than to the Bosnian conflict. The West made efforts to halt ethnic cleansing or human rights abuses by 
the Milosevic regime against the Albanian Kosovars. Therefore, the atrocities by Milosevic were halted relatively sooner in Kosovo than had occurred in Bosnia (Sihbudi, 2001a). The West's quick response helped diminish the suspicion of Indonesian militant Muslims towards the West. In Indonesia, hostile sentiment towards the West, mainly the US, was an effective tool for mobilising mass responses from Muslim groups.

Second, the peak of the Kosovo conflict at the end of the 1990s coincided with Indonesia's severe economic crisis, which in turn led to political turmoil within the state (Sihbudi, 2001a). Therefore, at the height of the Kosovo crisis, all efforts were concentrated on overcoming domestic problems; including Indonesian diplomacy which was directed at supporting the country's economic recovery. Consequently, Indonesian Muslims and the government were less attentive to international issues, including the Kosovo conflict which ordinarily would have raised their concerns. In addition, in 1999 Indonesia was occupied with a popular referendum on East Timor, and problems related to this referendum dominated its diplomatic efforts.

The presence of the US and other Western states in Kosovo sparked a notable contrast between Indonesia and Malaysia, the two Southeast Asian countries with the largest Muslim populations. The West's assistance to Kosovar Muslims in their fight against Christian Serbs appeared to stir up mixed feelings among Muslims internationally. These circumstances might have managed to reduce perceptions that the West was anti-Islam.

Against such a background, Malaysia supported NATO's air strikes to prevent further threats to Kosovar Albanians. Malaysia regarded these strikes as distinct from US-led military actions in Afghanistan, Iraq and Sudan which the Malaysian government had criticised. Malaysia's stance was described by Ambassador Hasmy Agam, Malaysia's Permanent Representative to the UN, as "a reluctant exception" to its traditional stance that all international security issues including those in Afghanistan, Iraq and Sudan should be addressed in the UN Security Council. Despite Prime Minister Mahathir Mohamad's sceptical feelings on the West's keenness to protect Muslims, Malaysia supported NATO's military actions in Kosovo (Vinocur \& Richardson, 1999).

Meanwhile, Indonesia issued a statement condemning the bombing and urging the two parties to refrain from the use of force, discontinue violent actions, and to return to negotiation. Indonesia stressed the importance of negotiation as a way to settle the 
problem, instead of through the use of weapons (Jakarta-Post, 1999a). Indonesia's position seemed to be consistent from the beginning in the sense that the country emphasised the importance of renegotiation and respect for the territorial integrity and the sovereignty of the Federal Republic of Yugoslavia (Jakarta-Post, 1999a). Kosovo had not come under the spotlight in the Indonesian press and it had not been a serious concern for Indonesian Muslim groups, thus there was little pressure from society contributing to the shape of Indonesian policy on this issue. In this case, the government had relative freedom in shaping its position regarding NATO's airstrikes in Kosovo.

Indonesia's position also reflected its concern over the violence and riots in the aftermath of East Timor's referendum which happened concurrently with the Kosovan crisis. In this regard, Jakarta had interests in shielding this violence from outside intervention (Vinocur \& Richardson, 1999). Therefore, Indonesia's position and statement regarding NATO's bombing in Kosovo was in line with its national interests.

The situation in Kosovo sparked a heated debate among Ministers attending the ASEAN Regional Forum in Singapore on July 26 1999. Among non-Western members of the ARF, some were concerned about NATO's unilateral military operations in Kosovo. They were afraid of the erosion of basic international principles that possibly resonated in their region. The debate caused 'a last minute hitch' in finalising the Chairman's Statement (Jakarta-Post, 1999b). Many compromises were achieved. Instead of expressing 'regret' for NATO's bombing, the statement only mentioned "concern with its wider implications". Indonesian Foreign Minister Ali Alatas's intervention helped overcome the standoff on how the issue should be addressed in the ARF Chairman's Statement. Alatas made additions to the statement to specify that NATO's military action was intended to halt war crimes and crimes against humanity. Therefore, the issue was moved away from sole reference to the bombings against Yugoslavia, and toward concerns regarding human rights violations. The ARF Chairman's Statement affirmed support for the UN Charter and international law and called for a political settlement. The Indonesian delegation argued that in Kosovo's case, the UNSC had been pushed aside and that international society should pay attention. Besides acknowledging the human rights abuses by Yugoslavia, the Indonesian delegation firmly stated that NATO's military action was not in accordance with the UN Charter (Jakarta-Post, 1999b). 
Ali Alatas's efforts to bring together opposing sides on the Kosovo issue for the sake of drafting the ARF Chairman's Statement were typical of Indonesia's point of view. The country has always tried to adopt a mediating position as long as the ideas have not directly touched its basic national interests. Many Indonesian observers have argued that Indonesia's positions have not been firm enough. Indonesia's non-confrontational or nonhostile views were reflected in its position responding to NATO's bombing in Kosovo. Instead of using the word 'condemn', Indonesia chose 'regret' to express its disagreement with the US and its allies' actions in Kosovo. Indonesia disagreed with these actions, arguing that they violated the basic principles of international law. Aside from criticising NATO, Indonesia also acknowledged the existence of human rights violations committed by the government of Yugoslavia (Jakarta-Post, 1999a, 1999b).

To this point, the interplay between Indonesia's state and society on the Kosovo issue has not been considered. In such a situation, the Indonesian government looked free to pursue a policy on the Kosovo crisis without any significant pressure from public opinion. The absence of a critical view from society with regard to NATO's bombing in Kosovo placed the government as the sole or dominant actor in the foreign policy decision making process.

This situation was very different from Indonesia's foreign policy behaviour in responding to the Bosnian crisis, in which pressures from Muslim groups were so strong. At that time, even the authoritarian regime of Suharto seemed, to some extent, to accommodate Indonesian Muslims' aspirations. The government was seen to have conducted some policies and actions which were in line with, or even pleasing to, domestic Islamic groups.

With regard to the Bosnia issue, Indonesia supported the adoption of the OIC resolution calling on the UN to impose economic sanctions and also take military actions to bring an end to the war initiated by Serbia against Bosnia-Herzegovina. As the Chair of the $10^{\text {th }}$ NAM Summit in Jakarta, from 1-6 September 1992, Indonesia spearheaded the issuance of the NAM Final Document which called for respect for the sovereignty, territorial integrity, and independence of Bosnia-Herzegovina. The same point was made in President Suharto's intervention in the meeting on the necessity of upholding sovereignty and territorial integrity as well as preserving the cultural heritage of Bosnia-Herzegovina. Suharto himself instructed that Indonesia should adopt a more concrete policy toward 
Bosnia-Herzegovina. Subsequently, the country recalled its ambassador to Yugoslavia, Sunjoto Pamungkas (Perwita, 2007). Further measures taken by Indonesia included sending 20 military observers and a 200-person medical detachment under the UN peacekeeping force (Suryadinata, 1995). Moreover, the visit of Suharto to BosniaHerzegovina to offer good offices to conflicting parties and to help build a mosque in Sarajevo was hailed and celebrated by Indonesian Muslim groups as a manifestation of Indonesia's strong support for the struggle of Bosnia-Herzegovina (Budiwanti, 2001; Perwita, 2007). Suharto's policies on Bosnia-Herzegovina were interpreted and remembered as a form of accommodation of Muslim aspirations (interview with Mahfudz Siddiq, 25/11/2003).

The post-Suharto regimes from Habibie to Megawati apparently did not have any concerns or clear policies towards Kosovo and Bosnia. A study by Budiwanti (2001) who conducted field research in Surabaya, Padang, Bandung and Yogyakarta in 2001 has confirmed this view. According to Budiwanti (2001), respondents realised that the government had been preoccupied with domestic problems politically and economically in the aftermath of the 1998 political and economic crisis. Rather than observing or playing a role in crises or conflicts abroad, Indonesia was busy handling its own separatist and communal conflicts in Aceh, Ambon, Kalimantan, Poso and other regions. Consequently, Indonesia under Habibie and Abdurrahman Wahid afforded less time to considering regional and international concerns, including the Kosovo crisis, and focused instead on domestic concerns.

\section{Indonesia's middle-ground position on Kosovo's independence}

Non-permanent member status in the UNSC in the period of 2007 to 2008 required Indonesia to be involved in debates regarding Kosovo's issues. Indonesia also sent a representative to join the UNSC mission to Kosovo between the $25^{\text {th }}$ and $28^{\text {th }}$ of April, 2007. The mission aimed to provide the UNSC with first hand information on the situation in Kosovo (UNSC, 2007a). Prior to Kosovo's independence, Indonesia faced a dilemma regarding its own position. This dilemma was observed by a leading political scientist from the Indonesian Institute of Sciences, Ikrar Nusa Bhakti. He said that support of Kosovo's right to independence had been mandated by the 1945 Constitution, noting that Kosovars suffered gross human rights violations. On the other hand, supporting the independence of Kosovo could challenge Indonesia's own territorial integrity (Jakarta- 
Post, 2007). According to Damien Kingsbury, Indonesia would experience an adverse impact on its two separatist-prone regions of Aceh and Papua if it supported the proposal of Kosovo's independence in the UNSC. For Indonesia, national integrity has always been a sensitive issue. However, Kingsbury's comments were rejected by Hikmawanto Juwana, an international law expert from the University of Indonesia. He said that Indonesia's support for the proposal of Kosovo's independence would not have a destabilising effect on its own territorial integrity (Jakarta-Post, 2007).

Such a situation led Indonesia to take a very cautious stance during talks on the final status of Kosovo. In early 2007, Foreign Affairs officials seemed reluctant to reveal the country's position. Wirajuda stated that "we haven't made any decisions as we are still discussing it" (Jakarta-Post, 2007). Having a dilemma with regard to its domestic affairs, Indonesia showed hesitation when faced with such a complicated situation. Despite its indecisiveness, the country tended to stand on Serbia's side. This tendency boosted Serbia's optimism that Indonesia would vote against any plan or proposal for Kosovo's independence. Indonesia had indicated its belief in the importance of respecting the territorial integrity of states (Ker-Lindsay, 2009, p. 4). A meeting between Indonesia's Foreign Minister and the Indonesian parliament on 8 October 2007 revealed the country's recognition of the sui-generis nature of Kosovo's case, its view on the necessity for dialogues supporting a comprehensive settlement acceptable to all, and its emphasis on territorial integrity as its temporary position until the both parties had reached a comprehensive settlement (Deplu, 2007b).

Indonesia's undecided position came to the fore when the UN Special Envoy for Kosovo, Martti Ahtisaari visited Jakarta for consultations with the Indonesian government as a member of the UNSC in April 2007. After the consultation, a presidential spokesperson stated that President Yudhoyono had not given any commitment to Ahtisaari's Comprehensive Proposal for the Kosovo Status Settlement (the Ahtisaari Plan) that envisioned supervised independence for Kosovo. Indonesia would monitor the situation and listen to other countries' views whilst waiting for the results of the UN mission visit to Pristina, Kosovo in May 2007 (Tempo, 2007).

In a meeting with the US, EU, and Russian Troika in early 2007, Wirajuda raised the idea of delaying Kosovo's final status which was linked with a promise to grant EU 
membership to Serbia. According to Wirajuda, it would be a much less sensitive issue if all parties, namely Serbia or Croatia or even Kosovo, became members of the EU. It would be better if the EU did not issue threats but rather offered incentives to Serbia in relation to the country's desire to join the EU. However, this idea was taken up by the EU. Wirajuda believed that if the Ahtisaari plan had been pushed through, it would likely have been vetoed by Russia (Kemlu, 2010). Eventually, the UNSC declined to endorse the Ahtisaari plan in July 2007 (Weller, 2008)

Soon after Kosovo's UDI, Indonesia issued a statement containing the following points: First, Indonesia's emphasis on the importance of respecting the national and territorial integrity of every UN member state as enshrined in the UN Charter and basic principles of international law. Second, Indonesia's mindfuness on the issue of Kosovo, which it regarded as a unique case considering the territorial and ethnic aspects of the break-up of the former Yugoslavia. Third, the country's emphasis on the necessity of dialogue and negotiations to reach a final status for Kosovo, which if agreed by all parties could avoid the possibility of any new conflicts and tensions. However, Indonesia noted its regret regarding the failure of dialogue between conflicting parties which led to the unilateral declaration of Kosovo's independence. Fourth, Indonesia was not yet in a position to recognise Kosovo's independence but would follow developments very closely (KBRIBelgrade, 2008).

The country's statement reflected its middle-ground position on independence. While Indonesia had not ruled out recognition in the future, it was concerned about the implications of independence and did not wish to endorse Kosovo's statehood in the meantime. Such a position had been also embraced by countries like China, Brazil, India and South Africa which had refrained from expressing a strong position one way or another (Ker-Lindsay, 2009, p. 4).

As the world's largest Muslim country, Indonesia had been expected by Kosovo to take its side. During a 2013 Helsinki meeting on strengthening the roles of religious leaders in mediation and conflict resolution, Kosovo's Vice Foreign Minister Petrit Selimi told Din Syamsuddin, the Chairman of Muhammadiyah, that Kosovo needed Indonesia to recognise its independence. The basis of Kosovo's plea was the fact that it is a Muslim country like Indonesia. Kosovo viewed Indonesia as a strategic country in the OIC and NAM (Aminah 
\& Festiani, 2013). Kosovars believed there were no legal or political reasons for any countries, especially OIC countries, not to recognise Kosovo's independence (Arabbews, 2013). Besides approaches from Kosovo, Indonesia had also been lobbied by other countries of the OIC. The Organising Committee Chairman of the Asian Parliamentary Assembly (APA), Senator Mushahid Hussain Sayed of Pakistan, urged Indonesia to recognise Kosovo's independence in a meeting with President Jokowi in December 2014, as it was in line with rights of self-determination (Daily-Times, 2014).

In response to such requests, Indonesia usually employs its rhetorical position that it is still following developments in Kosovo and will look closely at Kosovo's request, and that it is not impossible for Indonesia to recognise Kosovo at an appropriate time in the future. Such a statement was made by Yudhoyono at a question and answer session during his lecture at the London School of Economics (LSE) in March 2009. Wirajuda also expressed similar views to the above statement when meeting with Kosovo's Foreign Minister in New York in September 2009 (Kosovothanksyou, 2009).

Indonesia's response to Serbian lobbying has been similar. This lobbying has been conducted not only by the executive but also by parliament and civil society (particularly religious) leaders. After meeting with Indonesian Minister for Foreign Affairs (2009-2014) Marty Natalegawa on 19 March 2013, the Speaker of the Serbian Parliament, Neboja Stefanovic, said that his country received assurances that Indonesia will "continue to support the resolution of the Kosovo issue through dialogue, peaceful means and in line with international law and UN conventions" (b.92, 2013a). Previously Indonesia also supported the resolution sponsored by Serbia to bring the case to the International Court of Justice (b.92, 2008). During a bilateral interfaith dialogue between Indonesia and Serbia in Jakarta in October 2013, the Serbian delegation urged Indonesia not to recognise Kosovo's independence. Such a non-political forum was utilised by Serbia to express its political interests (Amrullah, 2013). But Indonesia's policy favouring Serbia's position was not solely because of Serbia's approaches or lobbying. According to Mohammad Fachir, a high-level official of the Ministry of Foreign Affairs, it is impossible for Serbia to dictate or influence Indonesia's policy to support or not to support Kosovo's independence (Amrullah, 2013). 
Indonesia's position seemed clearer in a forum like the OIC which has expected its members to recognise Kosovo's independence. Indonesia had opposed the adoption of a document supporting Kosovo's declaration of independence during the OIC Summit in Dakar, Senegal in March 2008. This document was proposed by Turkey (TodaysZaman, 2008). At the Islamic Conference of Foreign Ministers in Kampala in June 2008, Indonesia, together with Azerbaijan, Egypt and Algeria, once again opposed the recognition of Kosovo as an independent state (KosovaPress, 2008). Indonesia supports a peaceful settlement approach to Kosovo's issue. Indonesia has suggested bringing the problem back to the framework of UNSC resolution 1244, respecting the territorial integrity of Serbia.

\section{Debating Indonesia's position: The government vis-à-vis Muslim groups}

Kosovo's independence is widely promoted by Muslim groups in Indonesia, mainly from Muslim moderate groups, especially Muhammadiyah and MUI. MUI's chairman, Ma'ruf Amin repeatedly called for the government to recognise Kosovo. MUI's suggestion was based on the fact that Kosovo is a Muslim majority country and that it has already been recognised by many countries. MUI channelled this aspiration to DPR and MPR in order to put pressure on the government. As a member of the Presidential Advisory Council, Ma'ruf Amin would also use his position to forward MUI's concerns to the President. Meanwhile, the Deputy Chairman of MUI on Foreign Affairs, Muhyiddin Djunaidi said that MUI would conduct a series of meetings with experts in the field to discuss the recognition of Kosovo (Triyudha, 2011). On some occasions, MUI has received visits from Kosovan delegations such as Kosovo's mufti (religious leader), Rexhep Boja who visited Indonesia in August 2011. On this occasion, MUI had also arranged a meeting between Rexhep Boja and the chairman of DPR and MPR (MUI, 2011). During their visits, Kosovan delegations have raised Islamic solidarity sentiments with their Indonesian Muslim brothers. In Jakarta, Mufti Rexhep Bojasaid that recognition from the Islamic world is very meaningful as it provides significantmoral support for Kosovo's people (MUI, 2011).

MUI has recognised Kosovo as an independent state (MUI, 2011). It argues that the case of Kosovo is unique, different from secessionism as it is commonly understood, and that the Indonesian government's fear of inflaming domestic secessionism is unfounded (interview with Muhyiddin Djunaidi, 5/10/2013). An international law expert, Hikmahanto 
Juwana also holds such an opinion. He argues that there was no reason to delay recognition of Kosovo's independence as it meets all the requirements to become an independent state. He believes that the cases of Kosovo and Papua are very different, and that "Serbia perpetrated genocide on Kosovo while alleged human rights violations in Papua remain rumors" (Khalik, 2008). According to Juwana, the government should not be worried that recognition of Kosovo will encourage demands from Indonesia's restive regions to have independence. He believes that other countries such as the US will not support any separatist movements in Indonesia as they explicitly express their support for Indonesia's territorial integrity (Indarini, 2008).

Meanwhile, NU showed its support for Kosovo's independence by inviting Kosovo delegates to attend the $3^{\text {rd }}$ International Conference for Islamic Scholars (ICIS) in Jakarta in 2008. According to NU, the invitation was not intended as a form of pressure on the Indonesian government but was out of sympathy for Kosovo's independence claim. NU's chairman, K.H. Hasyim Muzadi said the recognition of the independence of Kosovo is the domain of the government. As an Islamic organisation NU only welcomed Kosovo's independence because the majority of its population are Muslims. He added that Kosovo Muslims would be safer if Kosovo was an independent state (NU-Online, 2008). Meanwhile, NU's vice chairman K.H. Said Agil Siraj, who is the NU's chairman in the periods of 2010-2015 and 2015-2020, made a stronger statement saying that the government must recognise Kosovo in order for Muslims in the territory to live peacefully (Novel \& Nuol, 2008). However, as time passed without the government showing any sign of recognising Kosovo, both Hasyim Muzadi and Agil Siraj became more silent. Muzadi believed that Kosovo's case should be looked at in terms of the requirements and processes to become a state. If these two elements have been met, he argued, there is no reason for the government not to recognise Kosovo (interview with Hasyim Muzadi, 29/12/2013). Meanwhile, Agil Siraj sees Kosovo's problem as an internal one and advocates not interfering with the domestic affairs of other countries. If there are human rights violations and crimes against humanity, Siraj argues that those should be condemned and Indonesia should intettrvene to help overcome the problem (interview with Said Agil Siraj, 11/11/2013).

If NU has indicated a shift of attitude, Muhammadiyah has been consistent, persistent and determined to support Kosovo's independence. According to the chairman of 
Muhammadiyah, Din Syamsuddin, there are at least three reasons why the government should support and recognise Kosovo. First, it is in line with Indonesia's 1945 Constitution stipulating that independence is the right of all nations. Thus, colonisation should be eliminated. Second, 96\% of Kosovars are Muslims (Jakarta-Post, 2012). As the country with the world's largest Muslim population, Indonesia's support for Kosovo's independence is needed (MuslimDaily, 2013). Third, the number of countries recognising Kosovo's independence has increased over time. Great powers such as the US, most of the EU member states, and NATO members, have all recognised Kosovo (myQuran, 2011). The ICJ advisory opinion stating that the declaration of Kosovo's independence did not violate international law further strengthens the necessity for Indonesia to recognise Kosovo (Puji, 2011) .

Din Syamsuddin contends that recognition is a manifestation of supporting brothers in the Islamic faith. Muhammadiyah has made various endeavours to urge the Indonesian government to recognise Kosovo's independence (Agung Sasongko, 2013). Muhammadiyah has also approached the government and parliament to address this matter. It has accompanied delegates from Kosovo to meetings with the country's parliament members and officials. On 10 August 2011, Din Syamsuddin accompanied Rexhep Bajo, Kosovo's Presidential Special Envoy and former Mufti of Kosovo, to have a meeting with the Vice Speaker for International Affairs, Priyo Budi Santosa from the Golkar Party and the head of Indonesian Inter-Parliamentary Cooperation Board (BKSAP), Sidharto Danusubroto from PDIP. In the aftermath of the meeting, Priyo Budi Santoso said that parliament regretted the government's position which did not yet recognise Kosovo. According to Priyo Budi Santosa, to at least some extent, parliament understands the government's position due to its concern about separatism. However, he said Kosovo's declaration of independence was not a form of separatism, but a struggle for independence as it had been colonised (DPR, 2011).

Priyo also questioned why the Indonesian government did not make a decision when the ICJ issued its advisory opinion on Kosovo. He thought that Indonesia should recognise Kosovo as it is mandated by the country's constitution, and noted the parliaments of Indonesia and Kosovo had agreed to enhance cooperation in various fields (DPR, 2011). 
Muhammadiyah also facilitated a meeting between Rexhep Boja and the leaders of the MPR, namely: Taufiq Kiemas (speaker), Farhan Hamid (vice speaker), Hajriyanto Y. Thohari (vice speaker), and Lukman Syaifudin (vice speaker), on 10 August 2011. In a response to Kosovo's request, MPR sent a letter to Yudhoyono suggesting that the government recognise Kosovo in line with the 1945 Constitution stating that independence is the right of all nations (Puji, 2011). Muhammadiyah had many times facilitated such meetings. The most recent one was between Ahmet Shala, the Ambassador of Kosovo to Japan with MPR's current chairman, Zulkifli Hasan, on 24 November 2014. The meeting was held after Ahmet Sala attended the $5^{\text {th }}$ World Peace Forum held by Muhammadiyah in Jakarta, on 20-23 November 2014. In this meeting, Din Syamsuddin mentioned that MPR under the chairmanship of the late Taufiq Kiemas supported and recognised Kosovo's independence. In a response, Zulkifli Hasan stated that independence is the right of all nations. Therefore, there was no reason for the government not to recognise Kosovo (MPR, 2014).

To gather support for Kosovo's independence, Muhammadiyah also conducted a Seminar on "Mengapa tidak mengakui Kosovo" (Why not recognise Kosovo)? in Jakarta on 16 May 2013. The seminar was attended by academics, the embassies of Serbia, Russia, and Syria, members of parliaments, MUI, NGOs, students, and others (Al-Intima, 2013). The seminar was aimed at opening 'the eyes of the government' and looking at the real situation to identify how important it was to recognise Kosovo. Din Syamsuddin had been invited several times by the President of Kosovo, Atifete Jahjaga, to look closely at the situation in Kosovo and the development of Islam there (Muhammadiyah, 2013). In his first meeting with Atifete Jahjaga at Kosovo's presidential palace on 17 May 2012, he expressed Muhammadiyah's full support for Kosovo, and promised his organisation would forge cooperation with its people. Muhammadiyah offered scholarships to Kosovan students who wished to study in universities belonging to Muhammadiyah. While welcoming Muhammadiyah's offer and support, the President of Kosovo explained that she expected the government of Indonesia to recognise her country. Taking into account Indonesia's strategic position in the Muslim world, its recognition would be followed by other states (Muhammadiyah, 2012). Din Syamsuddin had a meeting with President Atifete Jahjaga and Foreign Affairs Minister Enver Hoxhaj after he delivered a speech at a seminar in Kosovo, on $25^{\text {th }}$ and $26^{\text {th }}$ of May 2013. The President of Kosovo once again expressed her hopes that Indonesia would recognise Kosovo in an effort to create world 
peace and under the aegis of Islamic solidarity (Akbar, 2013). On several occasions, Din Syamsuddin also met with Kosovo officials including Kosovo's Vice Minister of Foreign Affairs, Petrit Selimi in Helsinki in January 2013 to discuss the development and recognition of Kosovo (Aminah \& Festiani, 2013) .

Din Syamsuddin's close connection and interaction with Kosovars may have led Muhammadiyah to commit to promoting the independence of Kosovo and urging the government to recognise it. Another factor is somewhat more primordial: Muhammadiyah perceived that Kosovo was historically and ethnically different from Serbia and therefore constituted a single entity entitled to be an independent state. As 96\% of Kosovo's population is Muslim, Muhammadiyah - as an Islamic organisation-felt an obligation to take care of the situation and the fate of Kosovars (MuslimDaily, 2013). According to Saleh Daulay, the chairman of the Muhammadiyah Youth, Muhammadiyah had an interest in ensuring that humanitarian freedoms could be employed by Kosovars. This organisation also saw the geographically strategic position of Kosovo as a Muslim country that lay on the European continent (interview with Saleh Daulay, 10/10/2013).

The consistency of Muhammadiyah has continued. On several occasions through mass media, Din Syamsuddin has urged the Jokowi administration to recognise Kosovo. He was optimistic that the government would recognise Kosovo as Jokowi had different views on implementing the free and independent foreign policy principle to Yudhoyono. Yudhoyono's 'million friends, zero enemy' foreign policy approach may have hindered his administration's recognition of Kosovo. With such a foreign policy platform, Yudhoyono's external actions often showed indecisiveness, including on the topic of Kosovo's independence (Akhmad, 2014). Under Jokowi, Indonesia is expected by Muhammadiyah to breakthrough this indecisiveness and deal with the Kosovo issue (Akhmad, 2014). At the $5^{\text {th }}$ World Peace Forum (WPF), Muhammadiyah also urged participants to support Kosovo. As expected, the efforts of Muhammadiyah did not go smoothly and many participants opposed the initiative. Serbia's ambassador walked out when seeing Kosovo's flag in the forum. Eventually, he came back during the lunch break and sat next to Kosovo's ambassador to Japan who attended the forum as a participant (Friastuti, 2014). 
The Indonesian government's position on Kosovo has been questioned by members of parliament including legislators from Islamic parties and also by nationalist parties such as the Golkar Party. Mahfudz Siddiq from PKS who has been the chairman of Commission I of DPR said that his commission had met twice with Foreign Minister Natalegawa to discuss the Kosovo issue. The Commission endorsed the government to recognise Kosovo, yet it received a noncommittal response which suggested that to recognise Kosovo's independence encouraged separatism (Amri \& Dewi, 2013). The government's fear was also suggested by Mahfudz Siddiq who claimed it was greatly worried about Papua. The fear of other countries' support for separatism in Indonesia prevented the government from recognising Kosovo. Papua had thus become an obstacle for Indonesian diplomacy (interview with Mahfudz Siddiq, 25/11/2013).

Another member of parliament, Hidayat Nurwahid from PKS, argued that Indonesia's attitude towards Kosovo does not reflect the country's identity as the the world's most populous Muslim state. The government's approach has been conventional: avoiding interfering with the internal affairs of other countries so as to prevent other countries from interfering in the internal affairs of Indonesia. However, according to Hidayat Nurwahid, the government has been excessively worried about its separatist problems. He claims that Indonesia will benefit if it recognises Kosovo and gets closer to the mainstream OIC countries and those Western countries that have already recognised Kosovo. Hidayat contends that the government's position is different from the aspirations of both Muslim groups and the parliament. He argues that separatism concerns should not hamper Indonesia's recognition. Many recognising states such as Turkey and some Gulf countries also face problems related to separatism (interview with Hidayat Nurwahid, 2/12/2013). Another Islamic party, PBB even issued an official statement which regretted the reluctance of the government to recognise Kosovo. Together with other Islamic components, the party steadfastly urges the government to support Kosovo (Gaffas, 2008).

Meanwhile, Hajriyanto Thohari from Golkar argues that there is no reason for Indonesia not to recognise Kosovo's independence, and that Kosovo has had the right to independence since it experienced human right violations in the 1990s. According to Thohari, there are two reasons why Indonesia should recognise the independence of Kosovo: First, the 1945 constitution condemns all forms of colonialism and oppression. Second, Indonesia as the world's largest Muslim democracy should defend oppressed 
nations such as Kosovo. Kosovo's status as a moderate Muslim country should also encourage Indonesia to support it (BeritaSore, 2008). The government's position was also questioned by another nationalist party politician from PDS (Prosperous Peaceful Party), Jeffry Massie. He criticised the slow response and unclear position of the government noting that the US and most of the EU states had recognised Kosovo (IndonesiaMatters, 2008). Another politician from Golkar, Tantowi Yahya objected to the government's fears about Kosovo's effect on Papua. He argued that the background and the problem of Kosovo is different from Papua (Adamrah, 2010).

However, in general, the parliament has not had one voice on Kosovo. The speaker of DPR has given his support to Serbia. He said that "Indonesia will continue to support Serbia's commitment to resolving the issue of Kosovo and Metohija through peaceful means and dialogue" (b.92, 2013b). Other lawmakers from nationalist parties such as Dian A. Syakhroza from PD and Murady Darmansjah from Hanura Party have supported the government's position. They stated that supporting Kosovan claims to independence could benefit secessionist groups in Indonesia. These groups could use Indonesia's support as an argument to demand or even to unilaterally declare their independence from the state (Asia-PacificNews, 2008).

Some leading Islamic scholars such as Azyumardi Azra and Bachtiar Effendy have also urged the government to recognise Kosovo. Azra has argued that more than five years since its independence, Kosovo has not been referenced by any separatist movements in the world. With this argument, he argued that the government's view that the recognition of Kosovo can strengthen separatist movements in the country is questionable and debatable (Azra, 2013). Meanwhile, Bachtiar suggested there was an indecisive and unclear position of the government due to Yudhoyono's million friends and zero enemies foreign policy. This lack of foreign policy assertiveness has left Indonesia behind in grabbing international momentum, including in the case of Kosovo. According to Bachtiar, the existence of Kosovo as a state is irreversible and the trend of recognising states has steadily increased. Bachtiar has warned the government not to become the $197^{\text {th }}$ out of 198 recognising states in the world (MuslimDaily, 2013).

The government remains robust in its position and is reluctant to bow to the suggestions, advice, and pressure from Muslim organisations and academe. The Indonesian government 
has never explicitly explained its position on separatist problems. Nor has it referred to the 1945 Constitution stipulating that independence is the right of all nations. Instead, Indonesia has consistently urged concerned parties to abide by international law such as resolution 1244 and to find a comprehensive settlement through dialogue and peaceful means. Such a consistent position can be traced through Indonesia's Permanent UN Representative's statements on Kosovo during its non-permanent membership of the UNSC (PTRI, 2008). Even when the Ministry of Foreign Affairs conducted a Foreign Policy Breakfast in May 2007 as an effort to gather input from domestic stakeholders, Wirajuda did not explicitly mention the possible implications of the Kosovo issue for Indonesia secessionism. He stated that "sensitivity of the issue for Indonesia is if the case is seen from the principle of respecting territorial and national integrity as well as its consequence. It is difficult to give such huge authority to the UN to decide a part of territories of an independent state to become an independent entity" (Kemlu, 2010, p. 153). It seems that the Foreign Policy Breakfast was conducted to anticipate domestic reactions to the country's involvement in the talks on Kosovo as a non-permanent member of the UNSC. The government was keen to prevent Muslim groups reacting in anger.

In not referring to the 1945 Constitution the Indonesian government appears to be concerned that Kosovo has seceded from Serbia. The assumption is that the government has not considered Kosovo as a colonised entity like proponents of recognition have deemed it. Consequently, in the view of the Indonesian government, Kosovo does not have the right to independence unless there is consent from Serbia as the mother state. Unlike Muhammadiyah and other Kosovo recognition proponents, the government does not use the 1945 constitution as their reference point in looking at this case. This is different from in the case of Palestine, which is discussed in Chapter Six. Both the government and other stakeholders including Muslim groups have referred to the 1945 Constitution as the basis of Indonesia's policy towards Palestine.

Avoidance of the use of the term of 'separatism' has not diminished suspicions that the Indonesian separatist problem is the main reason for the government's position. The author believes Indonesian public opinion got it right when contending that the separatist problem has been a determining factor for Indonesia's policy towards Kosovo. According to former Foreign Minister Wirajuda, Indonesia's recognition of Kosovo's independence would violate the general principles of sovereignty and territorial integrity of states. Separatist 
movements in the country could take momentum as a result of such a policy (interview with Hassan Wirajuda, 18/12/ 2013). Generally, the 'objection' to recognising Kosovo's independence is a fundamental and principled position. When Jusuf Kalla was approached by Martti Ahtisaari and Prime Minister of Erdogan of Turkey asking Indonesia to support Kosovo's independence, he objected to it. His reason for this was that Indonesia had just recently settled Aceh and was facing a separatist movement in Papua (interview with Jusuf Kalla, 4/12/2013). The government may be worried that if that principled position is not strongly enforced there will be repercussions for Indonesia's national integrity.

This concern was explained to the author by Wirajuda in referring to his discussion about Kosovo with the British Foreign Minister David Miliband. Miliband suggested not worrying about the repercussions of Kosovo for Indonesia's separatist problems, and claimed that states like the UK would not decline their support for Indonesia's territorial integrity. However, when Foreign Minister Wirajuda asked Miliband whether his statement could be relied on given that some British MPs have supported an international parliamentarian caucus for West Papua, Miliband could not respond. If the aspirations from British society and parliament were to increase, it might be possible for the British government to change its position. After such a response, David Miliband was apparently left speechless (interview with Hassan Wirajuda, 18/12/ 2013).

It is interesting that Muslim groups and intellectuals explicitly refer to national interests as a part of their argument. When attending a seminar on Indonesia's position on Kosovo on 23 November 2013 at the DPR's building, the author got the impression that almost all of the speakers and participants, consisting of university students in Jakarta, supported the recognition of Kosovo. However, most of the speakers and participants also stated that recognition was important for the sake of Indonesia's national interests. National interests in this context were interpreted as the implementation of the preamble of the 1945 Constitution which stipulates that independence is the right of a nation which accommodates societal aspirations, especially among Muslim groups. They stated that supporting efforts to free a country from colonialism as was the case with the recognition of Kosovo is mandated by the 1945 Constitution. Therefore, the recognition of Kosovo was considered a form of striving for national interests. 
The concept of national interest is very vague and therefore can easily be exploited and misused, particularly by politicians (Frankel, 1970; Griffiths, O'Callaghan, \& Roach, 2002). If the motives of the government are pushed by the necessity to maintain national territorial integrity, this can be viewed as a vital national strategic interest. Vital national strategic interests are supposed to have priority (Nye, 1999). The author argues that maintaining territorial integrity can be said to be the most important national interest of Indonesia. Jusuf Kalla, Wirajuda and Foreign Affairs officials view such a national interest as a fundamental position that the country should strive for.

The gap between the supporters of Kosovo's recognition and the government may be encouraged by a lack of information about the country's position. Foreign Ministry officials did not attend seminars on Kosovo held by Muhammadiyah on 16 May 2013 and by the Inter-parliamentarian Cooperation Board (BKSAP) on 23 November 2013 despite the fact that they were invited. The Ministry seems to prefer avoidance to direct information dissemination to audiences. There is also the impression that foreign affairs officials seemed to be avoiding public discussion on Kosovo in the aftermath of itsdeclaration of independence. This happened because of sensitivity surrounding the issue as well as the inclination of the public to question the government's position (interview with an official from MFA, 19/12/2013). Yet, as aforementioned, before the declaration of Kosovo's independence the government made an effort to have discussions on the matter with domestic stakeholders when the ministry held a Foreign Policy Breakfast in May 2007 (Kemlu, 2010). Likewise, a foreign affairs official, Dr Desra Percaya, was a speaker at a discussion on Kosovo held by Muhammadiyah's Centre for Dialogue and Cooperation among Civilisations (CDCC) on 22 July 2007 (Merdeka, 2007). However, in the aftermath of the declaration of Kosovo's independence in February 2008, officials of the Ministry of Foreign Affairs have seemed to prefer not to attend public seminars on Kosovo.

The Indonesian government has been persistent in its position. Aside from the government's perception that the recognition policy towards Kosovo is related to a principle and fundamental position on territorial integrity, other factors may have contributed to its stance. First, the magnitude of public pressure was not so great. Only Muhammadiyah was consistent with their views on the Kosovo issue, while other organisations such as NU were no any longer urging the government to make decisions in favour of Kosovo's independence. Islamic Youth organisations have been silent. Only Al- 
Irsyad Youth prior to Kosovo's independence was concerned about the matter (Al-Irsyad, 2012). Likewise, militant organisations have also been silent. Only HTI showed its concerns about the Kosovo issue through an article on its website, instead of conducting street protests like it usually would be inclined to do (HTI, 2008). Yet, HTI did support the independence of Kosovo (interview with HTI's spokesperson, Ismail Yusanto, 9/12/2013). Like HTI, other militant Muslim groups may face a dilemma over the US and Western role in Kosovo. The Kosovo issue may not be strong enough to consolidate power among their followers. The absence of militant groups' pressures may contribute to the relative absence of coverage in the mass media as the way militants express their goals are typically much more attractive to journalists than that of the moderate groups. The relative absence of major coverage has contributed to the lack of wider support from Indonesian Muslims. So far there has been no strong pressure from the parliament and/or huge demonstrations from Muslim groups against the government's position towards Kosovo (Azra, 2013). Consequently the situation has not put the government under major pressure.

Second, the level of urgency of the Kosovo case must be measured. Indonesian Muslims may view Kosovo as less urgent than Palestine and Bosnia (interview with Bachtiar Effendy, 4/10/2013). The Kosovo issue has not attracted considerable attention from Indonesian Muslims at large. They were apparently not well informed about the Kosovo issue (Kemlu, 2010). This situation had led to a low level of protest among Indonesian Muslim groups with regard to the Kosovo issue. The low level of protest has brought about the relative absence of real political convergence among various domestic groups. In this context, the interests of political elites have not converged with Muslim groups and their followers at the grass-root level (interview with Iis Gindarsah, 14/10/2013). As political elites in parliament and most Islamic organisations' followers at the grass-root level have not apparently considered Kosovo as an urgent issue, major pressure on the government has not been established. Consequently, the government's position on Kosovo has not had any meaningful challenges from society.

Third, Indonesia's non-recognition of Kosovo has not damaged or lessened its relations with countries that are the main supporters of Kosovo's independence, such as the US, the EU states, and other OIC member states. On the other hand, the country's political relations with Serbia have been significantly enhanced despite the decline of trade relations in the last five years. The trade relations accounted for US\$6.05 million in 2008. 
However from year to year both countries' trade transactions have declined, reaching the lowest point in 2011, namely US\$1.14 million. Yet, the trend has rebounded since 2012. The trade transaction amounted to US\$1.18 million in 2012 and US\$2.49 million in 2013 (Kemlu, 2013). The Serbian government also actively lobbied Indonesia to support its position on Kosovo. The Indonesian-Serbian Bilateral Interfaith Dialogue in Jakarta on 2326 October 2013 included the political interests of Serbia. In his October 2013 lecture before the graduate students of the Syarif Hidayatullah State Islamic University (UIN) in Jakarta, Serbian Mufti Muhammad Jusuf Pahic said that it is prohibited (haram) to support Kosovar Muslims who secceded (i'tizal) from the legitimate state and government of Serbia (Azra, 2013).

\section{Conclusion}

The above discussion shows us that the aspirations of some Muslim groups in Indonesia have been discounted by the government as they are perceived to confront the most central national interest. The government regards issues relating to territorial integrity as a fundamental and principal position which is non-negotiable. Although Indonesia's decision to delay recognition of Kosovo has been called unclear, and indecisive by its critics, the government's position, the author believes, is precisely consistent. It has unfailingly called for the upholding of international law and respect for territorial integrity, and for settling the problem peacefully through dialogue and diplomatic channels. Meanwhile, Muslim groups, especially Muhammadiyah, have criticised the inconsistency of the government's position regarding the 1945 Constitution. The constitution stipulates support for nations to have their independence and for all forms of colonialism to be abolished.

Muhammadiyah and other supporters of recognition of Kosovo's independence have kept questioning the government's position. The supporters of the recognition have often referred to the 1945 Constitution as the basis for their argument. A gap between the two sides has developed. The former implicitly views that Kosovo's declaration of independence is a kind of illegal secessionism from the mother state of Serbia. Meanwhile the latter considers Kosovo as a colonised entity that has a right to independence.

The government has never explicitly stated that fear of separatist-related issues was the basis of its position. Instead, it has always emphasised the fundamental principles of 
respecting territorial integrity. Against this backdrop, the government's position was criticised as indecisive and unclear. Muhammadiyah and other proponents of Kosovo's recognition believe that that the government's position is not about something principled or fundamental but instead about the foreign policy platform of a 'million friends and zero enemies'. But this platform has possibly changed for the future. Therefore, Muhammadiyah has promised to keep urging the government to recognise Kosovo and find all possible ways of helping Kosovo to have recognition from the government of Indonesia.

There is little evidence of major pressures from Muslim groups with regard to the government's policy on Kosovo. As time passed, Muslim groups have tended not to come forward with one voice on the Kosovo issue. NU's leadership, for example, has begun to understand the government's position on Kosovo. Similarly, members of parliament have not voiced the similar tune on the Kosovo issue. There has not been a convergence of Muslim groups' aspirations and the political interests of the parliament. There is not yet a strong momentum that unites their interests. Without massive pressure from society and parliament, it is difficult to change the position of the government. In such a situation, Muslim groups' aspirations are less effective.

Unless there is considerable pressure from Muslim groups and parliamentarians and as long as the government still considers that the recognition of Kosovo goes against its fundamental national interest, it seems unlikely Indonesia will change its position. 


\section{CHAPTER SIX \\ INDONESIA'S POLICY ON THE PALESTINIAN QUESTION}

\section{Introduction}

Indonesia has demonstrated its support for the Palestinian cause since the Sukarno era. This support has been expressed during international forums, including those of the NAM and the UN. Domestic political discourse has also been greatly coloured by sentiments of support for Palestine and enmity towards Israel (Lukens-Bull \& Woodward, 2011). Most Indonesian people do not consider support of Palestine to be a controversial standpoint. This consensus was demonstrated during the 2014 Indonesian presidential election campaign, when all candidates harnessed the issue in a bid to attract voters.

Since Indonesia's independence, the country's policy on Palestine has been consistent, but different nuances of support were demonstrated in the Sukarno, Suharto, and post-Suharto eras. There has been a gradual shift in attitude about how support for Palestine should be articulated. Generally, international issues related to the concerns of Muslims, including the topic of Palestine, were not freely articulated in the Sukarno era or the 25-year leadership of Suharto. These governments feared that Muslim political groups in Indonesia would exploit such issues for the sake of domestic political agendas. Indeed, during these two regimes, suspicions of Muslim groups were still paramount.

A number of scholars have debated whether Islam is a factor in the country's support for Palestine. Some, such as Suryadinata (1996) and Perwita (2007), believe that the Suharto era policy on Palestine was not related to Islamic sentiments. Suryadinata (1996) argues, for example, that Indonesia's non-recognition of Israel is based on Third World nationalism rather than co-religious factors. By contrast Sihbudi (1997), an Indonesian specialist on Middle-Eastern affairs, argues that Indonesia's relations with Middle-Eastern countries, including Palestine during the Suharto era, are inseparable from the Islamic factor.

Whatever the motivating factor, Indonesia has steadfastly committed to supporting the struggle of the Palestinian people to enjoy their rights in accordance with international law. Indonesia's 1945 Constitution mandates to abolish all forms of colonialism. Among the commonly articulated reasons why Indonesia supports Palestine is that the people of 
Palestine have been colonised by Israel. The fact that the majority of Indonesian people embraced Islam as their religion may have influenced the country to adhere to such a position. Therefore this chapter will discuss the role Muslim groups have played in the shaping of Indonesia's Palestine policy. Although a common argument in the literature holds that Indonesia's policies towards Palestine are simply based on universal values and humanitarian considerations, this chapter argues that although the country's policy has not been dictated by religious motives, Muslim groups' influence on its policy cannot be ignored. The aspirations and pressures of various Muslim groups have played a significant role in establishing a relatively consistent policy of support for Palestine. As the support on the Palestinian question has been in line with the 1945 Constitution, the government of Indonesia has seemingly ignored existing international pressures and has been principally concerned about domestic aspirations, especially among Muslim groups. In this vein, despite the aligment of both the government's interests and Muslim groups' aspirations, Skidmore and Hudson's statist-pluralist approach will be used to help capture the different nuances on this issue the from the Sukarno era to the Yudhoyono period.

\section{A brief overview of the Palestine-Israel conflict}

The conflict between Palestine and Israel constitutes one of the most protracted in the world, persisting since the establishment of the state of Israel in 1948 (Jaspal \& Coyle, 2014) (Friel \& Flak, 2007). The British mandate over Palestine (BMP) which began in 1922 ended when the British granted the governance of Palestine to the UN in November 1947. Having been backed by the US and without the agreement of Arab Palestinians or any of the Arab states in the region (Cheyfitz, 2014), in 1947 the UN issued resolution 181 which partitioned Palestine into two states: one Arab and one Jewish, with Jerusalem under international administration. The Arab state received $45 \%$ of total land under the British mandate, while the Jewish state received 55\%, leading to the establishment of the state of Israel in May 1948 (Dowty, 2005). The UN's decision was ostensibly a reaction to the impact of the European Holocaust (Golan, 2007).

This partition was rejected by the Palestinian Arabs and accepted by the Jews. The latter regarded it as a major victory toward the international legitimisation and recognition of the Jewish state (Dowty, 2005). Meanwhile, Arab Palestinians opposed the establishment of a Jewish state in the Middle East for the sake of accommodating Zionist aspirations. The Arabs also argued that the plan did not grant sufficient time for the establishment of a 
secular state for all people residing in Palestinian territory (Khamaisi, 2010). The partitioned lands based on the UN plan were regarded as unfair, because the Arab Palestinians as the majority (the population at the time was approximately $31 \%$ Jewish and $69 \%$ Palestinian) were granted a smaller allocation of land than that accorded to the Jewish population (Rubenberg, 2003).

This situation led to the Arab-Israeli War in 1948 between a group of Arab states (Egypt, Syria, Transjordan, and Iraq) and Israel. As a result of the 1948 Arab-Israeli War, Israel occupied a third more land (or in total around 78\%) than it had been granted in the UN's plan. Approximately 600,000-700,000 Palestinians became refugees as they fled or were expelled during the hostilities (Golan, 2007), and another 150,000 remained there under the control of Israel, isolated from the rest of the Arab World (Dowty, 2005). Jordan occupied the West Bank, a territory which was supposed to be part of an Arab state according to the UN's plan, and also took East Jerusalem. Meanwhile, Israel captured West Jerusalem and declared it as its capital (Golan, 2007). Both East and West Jerusalem constituted an area which was supposed to be governed by the international regime.

Israel reached armistice agreements with Jordan, Syria and Egypt in 1949. With some minor territorial adjustments and land exchanges, armistice lines became de facto, but not political, borders of Israel. Israel has never recognised these borders. The 1949 armistice lines had been developed-with minor changes - to be known as the 1967 lines which were created after the War of June 4, 1967 (Dowty, 2005; Golan, 2007, p. 3). The Six-Day War was described as a pre-emptive attack by Israel (Susser, 2014), conquering Egypt's Sinai Peninsula and occupying Syria's Golan Heights, the Gaza Strip and the West Bank, including East Jerusalem from which it formally withdrew in 2005. However, the UN still regards the Gaza Strip as occupied territory due to the siege of Israel in Gaza. During the Six-Day War, as many as 250,000-300,000 Palestinians fled or were expelled from their homes in Gaza and West Bank (Cheyfitz, 2014, p. 108; Rubenberg, 2003). The 1967 War shifted Israel's outlook from one of great anxiety regarding the threat of Arab states, to a sense of self-assuredness that Arabs would not be able to pose a serious threat to the country in the foreseeable future. Israel's self-confidence was boosted by its alliance with the US (Susser, 2014). 
Prior to the 1967 War, conflicts in the region occurred between Israel and opposing Arab states, but did not directly centre on the Palestinian people. Only after the 1967 War did the Palestinian cause become internationally regarded as a national liberation issue (Golan, 2007) with the Palestinian people as the main players. The Palestinian struggle had been spearheaded by the Palestinian Liberation Organization (PLO) which was established in 1964. Having originally adopted a non-recognition stance towards Israel as enshrined in the 1968 PLO's charter (Dowty, 2005), in 1988 the PLO formally embraced a more pragmatic approach by recognising UNSC resolutions 242 and 338 and declared that the Palestinian state existed within the occupied territories. This phenomenon explicitly showed that the PLO disposed of its aspiration to liberate Palestine and to establish it as a secular and democratic state. The PLO began to recognise a Palestinian state living side by side with Israel, now with only 22 percent of the BMP for the Palestinians. This meant that Palestinians accepted the West Bank and Gaza, with East Jerusalem as its capital, as their state's territories (Rubenberg, 2003). The unanimously adopted UNSC resolutions 242 and 338 called for Israel's unconditional withdrawal from the occupied territories in 1967. However, the PLO's recognition of the 1967 boundaries in 1987 was unappreciated or simply ignored by Israel (Friel \& Flak, 2007).

The change of PLO's official position was propelled, among other things, by the emergence of the First Palestinian Intifada in December 1987 as well as the rise of Hamas and the collapse of the Soviet Union (Dowty, 2005). The collapse of the Soviet Union led the PLO to lose its diplomatic support from the superpower (Rubenberg, 2003) and made the US, the strongest supporter of Israel, the dominant power in the world. In addition to restoring pride and self-reliance among Palestinians, the intifada also provided momentum for Hamas to rise. The resistance came as a surprise to Israel. It sent the state a message that the maintenance of the status quo, the continued occupation of the Palestinian territories, was not defensible in the long term (Dowty, 2005). The emergence of the intifada "made the two-state solution the logical solution" (Hilal, 2007, p. 5) and strengthened support for the two-state solution among Palestinians and Israelis (Dowty, 2005). The emergence of the intifada, the spectre of Hamas and other militant groups, and pressure from the US all combined to force both the PLO and Israel to move forward (Behrendt, 2007; Hallward, 2011). Against this backdrop, the PLO and Israel began to conduct peace deals. A number of peace initiatives and agreements stemmed from the Madrid Conference (1991) and were followed by Oslo I (1993) and Oslo II (1995), Sharm 
El-Sheikh (1999), Camp David II (2000), Arab Peace Initiative (2002), Peace Roadmap (2003), and the Annapolis conference (2007).

The Oslo Agreement in 1993 arguably constituted the most instrumental peace deal reached to date between Israelis and Palestinians. Despite being viewed pessimistically by some scholars, such as Said (2000), the two-state-solution proposed by the 1993 Oslo Agreement was generally hailed as a step in the right direction by many sides, including the US (Sihbudi, 1997). The Palestinians believed that through the Oslo Agreement (1993) they could achieve an independent state of Palestine in the West Bank and Gaza with East Jerusalem as its capital (Rubenberg, 2003). However, the peace agreement collapsed with the both sides contributing to its failure. This situation precipitated the Second Intifada in 2000 (Behrendt, 2007; Dowty, 2005).

No peace initiative has yet managed to bring about a comprehensive resolution to the conflict or create a lasting peace in Palestine. The Oslo Agreements and other peace initiatives failed to solve the issues of Jerusalem, refugees, settlements, borders, and security (Said, 2000). Non-compliance of the two parties with the existing agreements has been the subject of much scrutiny, particularly with regard to Israel's actions. Palestinians had shown their willingness to move forward from the 1967 boundaries, rather than from 1947 or an earlier time. This was a good opportunity for Israel to advance in the interests of a peaceful solution acceptable to both sides. Yet this was never properly appreciated in Israeli public opinion. Furthermore, Israel has frequently failed to respect international law, and specifically the UNSC resolutions, with regard to the Israel-Palestine conflict (Friel \& Flak, 2007).

Like the 1993 Oslo Agreement (also known as the 1993 Declaration of Principles), which marked a mutual recognition between Israel and Palestine, other agreements following the 1993 peace agreement have failed to break the impasse, and neither peace nor a Palestinian state has materialised (Jaspal \& Coyle, 2014). According to the Annapolis Agreement, an independent state of Palestine should have been established in December 2008, a year after the agreement was reached in 27 November 2007. However, this peace process failed when Israel attacked the Gaza Strip on 27 December 2008, three days before the deadline ended (Deplu, 2009). Despite recent peace initiatives proposed by the US, the impasse 
remains. Furthermore, Israel has often launched attacks on the Gaza Strip, with the most recent in March 2014.

The impasse and uncertain situation of the peace process has promoted radicalism on both sides (Rieken, 2014). Hamas and other Palestinian militant groups still strive to liberate the entire Palestinian territory. Hamas is considered a terrorist organisation by Israel and the US, just as the PLO was in the past (Rubenberg, 2003). In recent years, Israeli opinion has become more right-wing, hawkish and illiberal (Waxman, 2011, p. 70). Israelis' support of right-wing parties increases when Palestinian threats increase (Berrebi \& Klor, 2006). The rise of the right-wing has been demonstrated by the rise of the Likud party. The right-wing "supported the settlement as a religious and national obligation" (Dowty, 2005, p. 120) and advocated the integration of the occupied lands into Israel "on historical, nationalist, and security grounds" (p. 121).

Because of the uncertain future of the two-state solution peace process, many scholars such as Said (2000), Waxman (2011), Pappe (2007), Bakan and Abu-Laban (2010), Hilal (2007), Inbar (2009), Farsakh (2011), Dumper (2011) and Kelman (2011) propose a onestate solution as an alternative means of resolving the conflict. In contrast with popular opinion in much of the world, these scholars argue that ending the occupation and establishing a Palestinian state will not bring about peace. They contend that the establishment of a secular democratic state consisting of both Arabs and Jews offers the best hope of ending the protracted Palestine-Israel conflict.

Most Israelis and Zionists have challenged the one-state solution as it would lead to the extinction of Israel as a Jewish state. Supporters of the idea have been dubbed anti-Semitic by their critics. Meanwhile, diplomats and policy makers regard the proposal as unrealistic given the superiority of Israel's military (Dumper, 2011). The difficulty of applying the one-state solution has been detailed by Hilal (2007), who claims that "the main difficulty with the one-state solution resides in Zionism as a colonialist ideology and its insistence on a Jewish state conceptualising Judaism as a nation, not a religion or an aspect of culture" (p. 21).

The impasse of bilateral negotiations with Israel pushed the Palestinian authority to gain its independence through a multilateral vehicle. Palestine started to bid for international organisational membership under UN organs such as UNESCO. However it failed in its 
bid for UN membership as the country could not secure support from the UNSC in September 2011 due to a US veto. Instead, on 29 November 2012, Palestine was conferred with non-member observer state status - its downgraded bid-after the UNGA Resolution 67/19 was passed by a vote of 138 to 9 (UNGA, 2012). Israel condemned Palestine's upgraded status from non-member observer entity, which it had held since 1974. Israel depicted Palestine's move as a unilateral act violating the Oslo Agreement and threatening the existing peace process between Israel and Palestine (Jaspal \& Coyle, 2014). One month earlier, on 31 October 2011, Palestine had gained full membership of UNESCO with a vote of 107 to 14, with 52 abstentions.

Whether the approach pursued is a two-state solution or one-state solution, Israel under Benjamin Netanyahu seems reluctant to decide on a route forward. Israel has clung to the status quo with regard to its occupation policy, and this has led to questions about the state's commitment to peace (as cited in Cheyfitz (2014, p. 119)). This notion has also been indicated by statements made by Netanyahu on many occasions, such as his address before the US Congress on 24 May 2011. Netanyahu firmly rejected three issues, namely the return to 1967 borders, the return of the Palestinian refugees, and the plan to make East Jerusalem the Palestinian capital (Cooper \& Brinnermay, 2011). Netanyahu's speech was a response to President Barack Obama's suggestion for Israel to recognise the establishment of the state of Palestine based on the 1967 borders (Myers, 2011).

\section{The roots of Indonesian Muslims' sentiments towards Palestine and Middle Eastern issues}

There are a number of factors that must be considered when discussing international issues of concern to Indonesian Muslims. Firstly, religious relations between Indonesian Muslims and Middle-Eastern Muslims should be taken into account. Relations between Indonesia and the Middle East have, in general, been deeply entrenched. There is a wide-spread perception among Indonesian Muslims that Islam is synonymous with all things Arabic. Any issue related to Arabs or the Middle East is understood by Indonesians to be something related to Islam. Such an understanding leads to a perception of kinship between the two societies (Mehden, 1993). This may be termed a 'theological factor' in Indonesia's relationship with the region. As a result of this understanding that everything Arab is also Islamic, when Indonesian Muslims talk about the Middle East they will relate it to Islam. When Muslim students in Indonesia study Islamic history they study it as it 
relates to Middle-Eastern cultural contexts. Secondly, the distinctive place of Arab culture and Middle-Eastern society in the minds of Indonesian people may make it easier to predict what Muslims' reactions to Palestinian issues will be (interwith with Abdul Mu'thi, $16 / 10 / 2013)$. Given these factors it is unsurprising that there are often major reactions in Indonesia when issues relating to Middle-Eastern society arise.

Early interactions between Indonesians and Arabs occurred around the time of the advent of Islam in Indonesia. According to Buya Hamka, a well-known Indonesian Islamic scholar, initial contact took place in the seventh century. Islam was brought to Indonesia directly from the Arab peninsula, not from India (Azra, 2000). By the thirteenth century Islam was widespread in Indonesia (Ricklefs, 2008). The relationships between Indonesian Muslim society and the Middle-Eastern Muslim society had been mainly in the trading sector before cultural relations became the most important ones. Initially coming to Indonesia to trade, Arabs subsequently devoted their efforts to the fields of religion and education (Sihbudi, 1997). In the 1920s, political interactions became more apparent. PanIslamism and caliphate issues were crucial among Indonesian nationalists and religious societies. Both activist groups showed an interest in becoming involved with issues of the international Muslim community (Mehden, 1993). However, these issues have had only a marginal impact on current Indonesian politics.

From Indonesia's pre-independence past up to the present day, cultural relationships between Muslims in Indonesia and the Middle East have remained prominent. The Middle East has been the primary source of religious thought for Indonesians. Many Indonesian students have studied in the Middle East, mainly in Egypt and Saudi Arabia, and from an early age students are introduced to cities in the region and are familiar with Mecca, Medina, Jerusalem, Cairo, Karbala, and Damascus. Similarly, the politics and histories of states such as Iran, Iraq, Egypt, Jordan, Saudi Arabia, Palestine, Syria, and Lebanon are to some extent also recognisable to Indonesian students. Every year many Indonesian Muslims visit Mecca and Medina as part of their pilgrimage, as well as other cities such as Jerusalem and Karbala. These connections of knowledge, religious belief, and trade have made Indonesian Muslims so concerned about the Middle East, it is as if countries in the region were not foreign territories (Sihbudi, 1997). 
Indonesian Muslims have strong concerns about Palestine for several reasons. Firstly, Palestine is the place where Al-Aqsho mosque is located. It is the third holiest place according to Muslims around the world, including Indonesian Muslims. Muslims believe that the mosque is the destination of the prophet Muhammad before he ascended to heaven to meet God in a journey from Medina, Saudi Arabia. It has been described as both a physical and spiritual journey which is known in Indonesia as Isro' Mi'roj. Secondly, Gaza was the birthplace of Imam Syafi'i, one of the greatest ulema (Islamic scholars) and the greatest man according to followers of the Madhab Syafi'i (a school of thought within Islamic jurisprudence). The majority of Indonesian Muslims are followers of this madhab. Thirdly, Muslims in Indonesia are aware that the conflict between Palestine and Israel is a long and protracted one that has caused suffering to the Palestinian people. Indonesian people recognise the grievance of the Palestinian people who live in the occupied territories. They are greatly concerned about what they see as Israeli injustices toward Palestinians.

Conversely, Palestinians were also strong supporters of the Indonesian struggle for independence. The Palestinian Grand Mufti, Amin Al Husaini, expressed his congratulations to Indonesia at the time of the 'Japanese recognition' of the country on 6 September 1944. This recognition came ahead of Indonesia's official independence in 1945. The Grand Mufti's congratulations were broadcast on the radio for two consecutive days, and published in an Egyptian-based newspaper, Al-Ahram (Hassan, 1980). The independence struggle of Indonesia was also supported by many Palestinian people. For instance, Muhammad Ali Tahir, a Palestinian businessman, donated all his savings to supporting Indonesia's struggle to fight against the Dutch (Hassan, 1980). Other Arab countries were also very supportive. Egypt, for example, was the first country in the world to recognise Indonesia's independence. Popular Egyptian backing of Indonesian independence was evident in the acts of labourers at Port Said who boycotted Dutch ships passing through the Suez Canal. Likewise, the Arab League also supported Indonesia's struggle to gain independence (Hassan, 1980). This demonstrates the strong affinity between Muslim nations, including Palestine and Indonesia. Sihbudi (1997) argues that such strong solidarities and affinities have been possible and strengthened by co-religionist sentiments. 


\section{Indonesia's policy on the Palestinian question: Historical basis}

\subsection{The Sukarno period}

Many efforts have been made by Israel to build better relations with Indonesia. When the Dutch recognised Indonesia's independence in December 1949, Israeli President Chaim Weizmann and Prime Minister David Ben-Gurion conveyed their congratulations to President Sukarno and Foreign Minister Muhammad Hatta. In January 1950, Indonesia enjoyed Israel's full recognition as a new state. In response, Indonesia thanked Israel without reciprocally giving recognition of the latter as a new state (Muttaqien, 2013). Israel remained steadfast in its ambition to initiate a relationship with Indonesia, and proposed the opening of a legation in Indonesia. To that end, Foreign Minister Moshe Sharett wrote a letter to Hatta. On 6 May 1950, in his friendly response, Hatta "suggested that the mission be postponed to a later date" (Yegar, 2006, p. 140).

Moves to establish trade relations also began from the late 1950s. However, the government of Indonesia moved cautiously and surreptitiously to avoid adverse public reactions. As Sukarno's regime became more authoritarian and showed its left-leaning character, Indonesia's hesitant attitude towards Israel became more apparent. Eventually, the country expressed a clear stance of non-recognition of Israel. Its status as a Muslim majority country and its traditional relations with Arab communities, as well as the Arab states' assistance to Indonesia during its independence struggle, had become strong factors underlying its policy towards Israel. Relations were further strained when Indonesia ceased granting entrance visas for all Israelis - not limited for those holding diplomatic and service passports - in November 1953 (Yegar, 2006).

During this period, Indonesia candidly demonstrated its support to Arab countries when they were in conflict with Israel. This was understandable, as the states that offered early recognition of Indonesia's independence were Arab states. Following Egypt's recognition of Indonesia's independence, Saudi Arabia, Syria and Lebanon recognised the country in 1947, and Yemen in 1948. Furthermore, these states had lent their support from before the independence of Indonesia in 1945 until the Dutch recognition of Indonesia's independence in 1949 (Hassan, 1980). Indonesia remained in need of the support of the Arab states when struggling to gain West Papua from the Dutch in the 1960s (Muttaqien, 2013). 
Sukarno's world view increasingly led him to adopt an anti-imperialist stance. Sukarno believed that the world was operating under an exploitative system which he called the old established forces (Oldefos). These forces preserved and maintained the subjugation of new emerging forces (Nefos). Sukarno pronounced that Indonesia and other Nefos countries had to strive to defend their independence (Weinstein, 1971). From Sukarno's perspective, Arab countries were also part of Nefos. Meanwhile, Israel was positioned in the other camp, namely the Oldefos (Muttaqien, 2013; Weinstein, 1971). The establishment of Israel could not be separated from the support of Britain, France, and the US which were also classified by Sukarno as Oldefos (Dowty, 2005).

The Asian-African Conference, held in Bandung, Indonesia, in April 1955, took place without Israel's participation. Held in the spirit of anti-colonialism (Grovogu, 2011), the conference was attended by 29 countries of which fourteen were Arab and Muslim countries. Palestinian leaders were also invited, their attendance occuring as members of the Yemeni and Syrian delegations (Oded, 2010). Though initially supported by Burma, India and Sri Lanka, Israel's participation was blocked by Indonesia and Pakistan (Yegar, 2006). Furthermore, the adoption of a resolution in support of Palestinians led Israeli Foreign Minister Moshe Sharred to send a telegram in protest against Sukarno's position as chairman of the conference. The resolution was regarded by Israel as a humiliating defeat (Oded, 2010). As proposed by Indonesia, the second Colombo Conference was held in New Delhi, India in November 1956 in a response to the Sinai War involving Israel, France and Britain who were allied against Egypt. This war was precipitated by Egypt's nationalisation of the Suez Canal. During the conflict, Israel attacked Sinai and the Gaza Strip while France and Britain assaulted the Suez Canal area. The Sinai War brought about enmity among Indonesian Muslims towards Israel, France and Britain. At that time, there was pressure from the Indonesian parliament to cut diplomatic ties with the French and British. Indonesia supported the nationalisation of the Suez Canal by Egypt and then joined the UN Emergency Force (UNEF) deployed in the Sinai Desert (Sihbudi, 1997). The participation of Indonesian troops was questioned by the Israeli parliament as it was without prior Israeli agreement. Ultimately, however, Prime Minister Ben-Gurion's decision was not to react or protest (Yegar, 2006).

The most apparent early example of Indonesia's hostile stance towards Israel was the state's refusal to allow Israel to take part in the Fourth Asian Games in Jakarta in 1962. 
The exclusion of Israel and also Taiwan from the games led to Indonesia's suspension by the International Olympic Committee (IOC). This exclusion of Israel was "an omen of future sport events as Israel athletes were gradually excluded from other sports competition in Asian countries" (Yegar, 2006, p. 142). Indonesia's attitude was a response to domestic Muslim groups and Arab pressure (Leifer, 1983a). Leifer (1983b), has called such a stance a pragmatic approach to prevent the Muslim community's reaction and mobilisation.

Seen from Sukarno's framework, Israel's occupation of the Palestinian territories was the manifestation of imperialism and colonialism. Furthermore, Israel was regarded as a 'bridgehead' of Western imperialism in the newly independent Asian-African area (Barton $\&$ Rubenstein, 2005). Conversely, according to Sukarno, Palestinians had every right to establish an independent state in their territories. Barton and Rubenstein (2005) argue, therefore, that Indonesia's policy of non-recognition of Israel and its support for Arab states under Sukarno were much more about anti-imperialism and colonialism rather than Pan-Islamism motives.

However, Sihbudi (1997) argues that Indonesia's policy towards the Middle East, including its relations with, and non-recognition of, Israel was inseparable from the Islamic factor. Any policy set by the government always considered Muslim aspirations. Indeed, with the exception of the Socialist party, political leaders and groups in Indonesia generally gave their consent to the government's policy towards Israel and condemned Israel's actions against Palestinians. In a nutshell, this anti-Israel stance was not only shared by Islamic political parties, but it also "cut across party lines" (Yegar, 2006, p. 142).

The way in which foreign policy elites considered public interests in their support for Arab countries has been detailed by Weinstein (1971). The two major political streams, the Islamists and the nationalists - represented by the Masyumi party and the Indonesian National Party (PNI) — came to a "mutual desire for more outspoken support of the Arab" (p. 116). They argued that the government of Indonesia should have given stronger support to the Arabs. However, these camps came to two quite different conclusions in this regard. The nationalists believed that the central issue of the Israel-Palestine conflict was antiimperialism, while Islamic groups saw it as a matter related to religious solidarity. Both 
viewed Israel as "an essentially western intruder and the Arabs as victims of the extension of western influence in the Middle-East" (p. 120).

\subsection{The Suharto period}

The change from Sukarno to Suharto brought a more moderate and pragmatic foreign policy outlook for Indonesia with regard to the Arab-Israeli conflict. Despite a more nuanced approach, the fundamental stance of Indonesian policy on the matter remained largely the same. There had been an institutionalisation of support for the Arab cause and official relations with Israel were discouraged (Barton \& Rubenstein, 2005). But the pragmatic attitude had been apparent when Indonesia called for direct negotiations between Israel and Arab states after the 1967 war. This was a sensitive issue given that Arab countries still refused to recognise Israel at that time.

After the 1973 war, Indonesia did not commit to applying an oil embargo, as called for by Arab countries, against those supporting Israel such as the US, the Netherlands, Canada, Portugal, Rhodesia and South Africa (Bickerton \& Klausner, 2010). Indonesia's nonparticipation in the action was precipitated by its shifting orientation toward the West (Muttaqien, 2013). Indonesia needed the West for its economic development. Suharto's regime defined the country's national interests in terms of security, stability, and economic development, which encouraged a pragmatic approach when considering the Arab-Israeli conflict. The Suharto government preferred to emphasise its economic and security interests. US Oil companies such as Mobil Oil (Exxon Mobil) began operating in Indonesia right after Suharto came to power in 1968 (Muttaqien, 2013). Therefore Indonesia's participation in the oil embargo would have threatened to harm its economic development, which depended on foreign aid and investment due to domestic weaknesses (Weinstein, 1976).

A more neutral stance was also demonstrated by Indonesia when responding to the 1978 Camp David Agreement between Israel and Egypt (Leifer, 1983b). This stance was different from most Arab countries' reactions to the agreement. At that time, Egypt was politically isolated by its neighbours. Indonesia's position was further articulated when the country abstained - along with Malaysia and Bangladesh - from voting for Egypt's OIC membership suspension at a meeting of the OIC in Fez, Morocco, in May 1979 (Barton \& Rubenstein, 2005). 
Indonesia's long road to opening a PLO office in Jakarta indicated a subtle shift in its policy. The establishment of such an office had been suggested since 1972 by Indonesian Foreign Minister Adam Malik, but it was not permitted until 1989, taking 15 years to be realised (Yegar, 2006). A number of factors underpinned Indonesia's stance on PLO representation. First, the Indonesian military was concerned about the PLO's alleged ties with the communist bloc during the 1960s and 1970s (Leifer, 1983b). Second, the military also worried about the spread of terrorist acts by factions within the PLO and increased radicalism among the Indonesian Muslim community. Third, the government wished to avoid Western perceptions that Indonesia was close to the PLO. Opening a PLO office would only endanger Indonesia's relationship with the US. Therefore, Indonesia needed to have a green light from the US before allowing the PLO to open its office in Jakarta (Perwita, 2007). Another reason was the concern that the PLO office would monitor Indonesia's secret relations with Israel (Yegar, 2006). In September 1979, for example, both countries made a deal enabling Indonesia to purchase 14 A-4 Skyhawk aircraft and two TA-4 Skyhawk trainers from Israel (Leifer, 1983b).

The delay in allowing the PLO to open its mission seems to contradict Indonesia's official support for Palestine. This position of support was clearly expressed by Suharto before the Indonesian parliament on the occasion of the $36^{\text {th }}$ anniversary of independence in August 1981. He stated that "our attitude toward the problems of the Middle East has always been clear from the beginning, that is, we stand on the side of the Arab peoples and that of the people of Palestine who are fighting for their just rights against the arrogant aggression of Israel" (quoted by (Leifer, 1983b, p. 156)). In addition, Indonesia has always endorsed declarations, resolutions or any outcome documents produced during international meetings which support the Palestinian people in their struggle against Israel (Leifer, 1983b; Perwita, 2007). Suharto's publicly expressed formal position was likely aimed to appease domestic Muslims and Arab countries in relation to the Palestinian cause.

The permission for the PLO to open its office in Jakarta in 1989 occurred in the aftermath of Indonesia's recognition of a Palestinian state, which was proclaimed in Algiers on 15 November 1988. This decision came about when the government of Indonesia finally considered that the PLO "no longer posed a serious threat" and when Indonesia sought wider support for the NAM chairmanship in 1992 (Suryadinata, 1995, p. 294). Indonesia's attitude toward the opening of the PLO office in Jakarta did not escape reactions from 
Muslim groups. NU and Muhammadiyah, for example, criticised the government for showing an inconsistent policy towards Palestine. Indonesia's stance on this matter was regarded as dependent on US policy towards the Middle East. Muslim groups seemed justified in their allegations that the opening of the PLO's mission hinged on a green light from the US (Perwita, 2007). Despite collective reactions by Muslim groups, however, it should be acknowledged that, under Suharto's authoritarian regime, Indonesia's foreign policy was largely determined by a small group of elites. Suryadinata (1996) explains that these elites came from the Ministry of Foreign Affairs, the military, the state secretariat, and naturally included President Suharto himself. This small group believed that, in the attainment of the country's national interests, it was not necessary to uphold Islam as a primary concern (Sukma, 2003).

The country's permission for the opening of the PLO office in Jakarta was concurrent with Suharto's political rapprochement with Muslim groups. Some arguments have emerged to explain Suharto's political accommodation of Islam, as discussed in chapter two of this thesis. The change in Indonesia's attitude met with a positive response from Muslim groups, especially moderate groups such as Muhammadiyah. Muslim groups believed that this evolving outlook would also remove Middle-Eastern countries' doubts about Indonesia's intentions toward Palestine. However, militant Muslim groups such as KISDI and DDII still considered that Indonesia's policy of support had not been strong enough (Perwita, 2007).

The 1993 Oslo Agreement prompted both positive and negative reactions in Indonesia. The government welcomed the agreement which was supported by NU whose chairman, Abdurrahman Wahid, argued that only by recognising the existence of Israel could comprehensive peace be achieved. Meanwhile, the 1993 Oslo Agreement met with a negative response from Muhammadiyah, KISDI, DDII and the Indonesian Committee for the Liberation of Palestine (ICLP). They viewed that the agreement was a loss for the Palestinians and created an advantage for Israel and the US (Perwita, 2007).

The revelation by Israeli daily Haaretz about the secret visit to Jakarta of the Israeli Ambassador to Singapore, Daniel Megiddo, in July 1993, and the visit of Prime Minister Yitzak Rabin to Jakarta on 15 October 1993, created suspicions among Muslim groups that there was a plan to establish diplomatic relations between Indonesia and Israel. These 
Israeli visits sparked strong reactions from Muslim groups. The possibility of protests as a result of Rabin's visit was actually anticipated. His visit was not arranged according to state protocol and the meeting was held in Suharto's private residence rather than the state palace (Perwita, 2007). The visit was not publicly announced until Rabin left Jakarta, as the government were wary of alarming Indonesian Muslims (Paris, 1996). However, this did not prevent protests from Muslim groups such as Muhammadiyah (Perwita, 2007).

In an attempt to minimise the protests, it was announced that Suharto had been acting in his capacity as the chairman of the NAM, in spite of his being the President of Indonesia (Paris, 1996). With such an explanation, it was hoped Muslim groups' suspicions about diplomatic relations between Indonesia and Israel could be neutralised. Perhaps learning from previous experience and fearing adverse reactions from the public, Indonesia denied Prime Minister Netanyahu's request to visit Jakarta during his Asian tour in August 1997 (Yegar, 2006). From that time until Suharto stepped down from power in 1998, there were not any further moves by the Indonesian government to establish diplomatic relations with Israel.

\section{Indonesia's persistent non-recognition policy towards Israel in the post Suharto era}

The issue of Indonesia's diplomatic relations with Israel has always been inflammatory among many Indonesian people, particularly for Muslim groups. In the post-Suharto era, the voices of both moderate and less moderate Muslim groups have been more freely articulated. Previously constrained from expressing their political aspirations, Muslims are now able to express their viewpoints not only through mass non-political organisations such as the NU and Muhammadiyah but also through Islamic political parties such as PBB and PKS where they actively express their concerns about the fate of the Palestinians. They do so through parliamentary fora and demonstrations in the streets by rallying their supporters and cadres. As such, they have managed to act as checks and balances on the government's policies on Palestine and other international issues which concern them.

\subsection{Abdurrahman Wahid's adventurous proposal}

None of the ASEAN Muslim majority countries, namely Indonesia, Brunei Darussalam, and Malaysia recognise Israel. Israel expected that recognition by Egypt and Jordan; the establishment of Israel's diplomatic relations with China, India and South Korea; and that 
the signing of the 1993 Oslo Agreement would lead Southeast Asian Muslim states and other Asian Muslim states (such as Pakistan, Bangladesh, and the Maldives), to establish diplomatic relations with Israel (Yegar, 2006). However these expectations did not become reality. For Indonesia's part, Suharto reaffirmed on several occassions that Indonesia had never considered opening diplomatic relations with Tel Aviv (Sihbudi, 2007a).

Because of the difficulty of influencing this state policy, Israel started engaging Indonesian civil society especially Muslim leaders and Muslim intellectuals and journalists. Abdurrahman Wahid (NU), Habib Chirzin (Muhammadiyah), Djohan Effendi (Department of Religious Affairs) and Bondan Gunawan (Democracy Forum-Fordem) attended a seminar on Judaism and Islam held by the Truman Institute in Jerusalem in October 1994. With the invitation of PM Yitzhak Rabin, they were present at the peace accord signing ceremony between Israel and Jordan. It is also rumoured that they had a meeting with the Israeli Vice Foreign Affairs Minister (Sihbudi, 2007a; Yegar, 2006). On his return to Indonesia, Wahid, who was NU's chairman at the time, lobbied the government of Indonesia to establish diplomatic relations with Israel, arguing that it would be beneficial for Indonesia in the international arena. Wahid said that "it is time for Indonesia to open diplomatic relations with Israel. By doing so, we would be able to play a more important role in helping the struggle of the Arab nations" (Sihbudi, 2007a, p. 339).

The Indonesian civil society delegates' visit to Israel and Wahid's statement sparked protests from various Muslim groups. MUI and the chairman of Muhammadiyah, Amien Rais, for example, strongly condemned their visit and Wahid's statement. Yegar (2006, p. 150), The criticism not only came from the Muslim groups but also from Foreign Minister Ali Alatas who regretted their visit to Israel (Republika, 1994). Opposition also came from inside the NU. This opposition was significant but not overwhelming (Barton, 2002). Some NU leaders, such as K.H. Moch Ilyas Ruhiyat, chairman of the NU legislative council (Rois Am), argued that Abdurrahman Wahid's visit and his statement was not made in his capacity as chairman of NU, but instead in a personal capacity (Perwita, 2007).

As a democrat and pluralist, Wahid stood by his conviction and was not obviously bothered by the criticism. At an academic conference in Bali in June 1995 he once again stated the need for Indonesia to establish diplomatic relations with Israel (Yegar, 2006). 
Despite criticism, he made other visits to Israel. He visited Israel three times before becoming president and one time after stepping down from his presidency (Barton, 2002). Having been elected as the President of Indonesia in January 1999, Wahid embarked on a bold programme to realise his long held reformist, democratic, and pluralist convictions, including the promotion of a relationship with Israel (Barton \& Rubenstein, 2005).

Three days after being inaugurated, Wahid flew to Bali and addressed an international business meeting on 24 October 1999. He took the opportunity to express his intention to establish economic and commercial relations with Israel. On his return to Jakarta, Wahid met 16 ambassadors from Arab states and explained that his proposal did not include diplomatic relations. Instead, his plan would be similar to what some Arab countries had already done, namely establishing a commercial office in Israel (Associated-Press, 1999). Both President Abdurrahman Wahid and his Foreign Minister, Dr Alwi Shihab, affirmed that Indonesia would remain committed to its principles of supporting Palestine and would not establish diplomatic relations with Israel until a comprehensive solution for the Palestinian question could be reached (Jakarta-Post, 1999f).

Sukma (2003) and Sihbudi (2001b) observe that considerations underpinning plans to establish commercial ties with Israel not only revolved around economic factors. Wahid wanted to show that he was consistent in his pluralism and interfaith-tolerance. There was also his conviction that initiating commercial ties with Israel would become a shortcut for Indonesia's economic recovery (Sihbudi, 2001b). This plan was expected to provide Indonesia with an opportunity to attract Jewish and foreign investors to Indonesia. There is a common belief among Indonesian people that the world economy is dominated by Jewish people. As Wahid's Foreign Minister, Alwi Shihab argued: "We have to be frank, the Jewish lobby in the American Congress is very strong" (Gee, 2000a). Therefore, it was not surprising that President Abdurrahman Wahid linked national economic recovery with commercial ties with Israel. Finally, trade relationships with Israel would provide opportunities for Indonesia to play a more pivotal role in the Palestine-Israel conflict (Sihbudi, 2001b).

Wahid's plan was actually downgraded from his earlier suggestion before assuming the presidency, as he had previously advocated diplomatic relations with Israel. He became more pragmatic when he was in power and shelved his long-held personal convictions and 
aspirations to establish diplomatic relations with Israel. The Indonesian government, and specifically the then-Foreign Minister Alwi Shihab, declared that Wahid's plan to strengthen commercial ties did not imply the establishment of diplomatic relations and did not sacrifice the country's basic principles of supporting the Palestinians to have an independent state.

Despite this declaration, Wahid's plan received strong protests from both moderate and militant Muslim groups as well as Muslim student associations. Demonstrations took place in many cities and attracted large crowds. KISDI, the Jihad Militia Force (Laskar Jihad) and other Muslim components rallied in front of the Ministry of Foreign Affairs on 1 November 1999. They demanded that Alwi Shihab resign if he backed the plan, and urged the government to pay attention to Muslim anti-colonialism aspirations. They argued that establishing trade with Israel meant violating the country's constitution, and that there were no significant benefits for Indonesia to trade with Israel anyway. Hidayat Nur Wahid, a leader of the Justice Party (PK), an Islamic party, which had been renamed PKS before the 2004 election, stated that "we hope the minister will not open economic ties with Israel. Israel is colonising the Palestinian state. Indonesia must take a firm and serious stand. If he [Alwi Shihab] can't resist the pressure from the Zionists and their ally, the United States, he'd better resign" (Antara, 1999a). Even stronger views were expressed by MUI, stating that President Wahid "sold out his brothers in Palestine" (Solomon, 1999).

Responding to mounting pressure from Muslim groups, Wahid argued that it was in Indonesia's interest to open trade relations with Israel. He justified his plan with theological explanations. He questioned why Indonesia had had relations with China and the Soviet Union as communist states, but would not consider relations with Israel. He said that "in their [China and former Soviet Union] constitutions both of them clearly oppose God. Meanwhile Israel has never opposed God, so why should we make such a fuss about them? We must be more mature" (as cited by Sukma (2003, p. 113). Alwi Shihab, also gave a defensive response. He regarded Wahid's plan as a rational and pragmatic approach to the country's economic recovery (Gee, 2000a).

The government's persistence in proceeding with Wahid's proposal ignited demonstrations in Jakarta and other cities. On 12 November, KISDI held tabliq akbar (an Islamic public rally) condemning the plan. Ahmad Sumargono, a chairman of KISDI, demanded the 
government cancel its plan to launch trade ties with Israel, which he argued would trap Indonesia under a Zionist thumb. KISDI warned that should the government push its plan, there would be internal conflict and national disintegration (Jakarta-Post, 1999d). Meanwhile, KAMMI rallied to oppose Wahid's plan in a number of Indonesian cities, considering it an offense against Muslim people (Qodari, 2001).

Moderate Muslim groups - the modernist Muhammadiyah and the traditionalist NUstood side-by-side with militant Muslim groups in protesting the President's plan. Former Muhammadiyah chairman, Amien Rais affirmed that Indonesia would never recognise Israel as long as it occupied Palestine (Gee, 2000b). Wahid then had to seriously reconsider his plan when dozens of NU ulemas, dubbed Kyai Khos (special Islamic clerics) by NU followers, began to exert political pressure. Kyai Khos sent Kiyai Haji (KH.) Abdullah Faqih and KH Ahmad Sahal to meet Wahid personally and to urge him to drop his plan. Led by KH Abdullah Faqih, Kyai Khos had been among those who had supported Wahid's presidential nomination. They were greatly respected, and were considered gurus by Wahid and other NU followers (Jakarta-Post, 1999g).

The DPR had started being more responsive to the population's aspirations than it had been in the Sukarno and Suharto eras. In these two eras, both civil society and parliament did not freely articulate their functions and voices. In the post-Suharto era, Muslim groups appeared to secure more effective channels in parliament. In the Palestinian cause, DPR voiced the same concern with Muslim groups. The chairman of DPR's Commission I on foreign affairs, Yasril Ananta Baharuddin, for example, said that DPR would never let the government open diplomatic relations with Israel. The establishment of trade relations with Israel would also require consultation with parliament (Antara, 1999b).

In the face of such sizeable and strong protests and criticism, Wahid's administration backtracked. A postponement was declared after the government's debate with DPR on 18 November 1999. The Foreign Minister stated that "direct trade relations with Israel were postponed because the government is responsive to the people's aspiration" (Gee, 2000b; Sukma, 2003, p. 115). According to Sihbudi (2001b), had Wahid pursued his plan to open trade ties with Israel, there might have been questions about Indonesia's support for the Palestinians, accusations that the government violated the 1945 constitution urging the 
abolition of all forms of colonialism, and declining economic and political relations with the Middle East.

Wahid had created difficulties for his government by proposing such a plan. Such a complex and sentiment-filled issue should have been handled more cautiously. He may have been aware of this situation. Wahid tested the water in the early days of his Presidency by raising the issue in order to gauge public reaction as well as the reaction of political elites. Aside from receiving public opposition, Wahid did not appear to win any academic debates regarding his proposal to establish trade relations with Israel (JakartaPost, 1999e).

With issues considered sensitive by Muslim groups, such as Indonesia's recognition policies towards Israel, it is hard not to say that Islam - in this context in its political movement which is manifested by Muslim groups-has significant influence in Indonesia's foreign policy. The empirical evidence offered above supports this assumption. Moreover, in the post-Suharto era, the government has not had relative dominant power over its people as Sukarno and Suharto did. Wahid was more limited in his choices for conducting foreign policy, as other foreign policy stakeholders - especially Muslim groups - expressed strengthened voices and played more significant roles in the foreign policy decision making process. Therefore, subsequent regimes pursued more cautious policies. There remains almost no support among Indonesian society for the establishment of official relations with Israel, be it in diplomacy, trade, or even social and cultural ties.

\subsection{The Yudhoyono period}

Yudhoyono's policy towards Palestine continued largely unaltered from the Abdurrahman Wahid era, but it was more clearly articulated. In comparison to Wahid's speculative policy, Yudhoyono preferred to adopt a more cautious approach. His idiosyncrasy that tended to bring the country to play a more important role in the regional and international arena coloured his policy on the Palestinian-Israeli conflict. Yudhoyono has been seen as a president with considerable interest in and concern for world issues. His educational background in the US (both in civil and military training) and his experience of being assigned abroad established his credentials as an able foreign policy actor in Indonesian 
affairs. Yudhoyono's concerns for and solidarity with Palestine were reflected through international initiatives that his government proposed.

The 2004 Presidential election which brought Yudhoyono to power marked the beginning of a consolidated democratic era in Indonesia which tends to prompt political leaders to pay more attention to domestic aspirations. Given that the majority of people in Indonesia are Muslims, it is normal for the Indonesian President to consider their religious concerns. Against this backdrop, Indonesia's policy towards the conflict between Palestine and Israel may be put in its context.

Since the beginning of his first term, Yudhoyono affirmed that Indonesia would not establish diplomatic relations with Israel until Palestine became an independent state living side-by-side with Israel. His support for the Palestinians was further demonstrated by his visit to Egypt in November 2004 after the death of Yasser Arafat, during which he expressed his condolences and condolences on behalf of the Indonesian people. He was joined by prominent Indonesian Muslim leaders, Hidayat Nurwahid from Islamic party PKS who was also Speaker of MPR, Din Syamsuddin from MUI, Hasyim Muzadi from NU, and Amin Abdullah from Muhammdiyah (Azra, 2006). Although the roots of the Palestine problem revolve around occupied territory, the signal Yudhoyono sent by bringing Muslim leaders from Indonesia was appropriate given that the dominant groups of Indonesian society with concerns about the Palestinian question are Muslims. Yudhoyono's actions ostensibly indicated that he had the same aspirations as his fellow Indonesian Muslims (Kemlu, 2012b).

Indonesia's support for Palestinian statehood was also demonstrated during the AsianAfrican Summit in Jakarta, in April 2005. As the host, Indonesia proposed the adoption of a document called the Declaration on the New Asian-African Strategic Partnership (NAASP), which was signed by heads of state/governments or their representatives from 106 Asian and African countries. Palestine was the only participating country that had not yet been declared independent. The document clearly mentioned the Asian and African countries' support of Palestine, as demonstrated by the statement: "We express our abhorrence that, fifty years since the 1955 Bandung Conference the Palestinian people remain deprived of their right to independence. We remain steadfast in our support for the 
Palestinian people and the creation of a viable and sovereign Palestinian state in accordance with relevant United Nations resolutions" (Kemlu, 2005, pp. 1-2).

Yudhoyono's regime steadfastly demonstrated its commitment to the NAASP's solidarity on Palestine by holding the NAASP Ministerial Conference on Capacity Building for Palestine in Jakarta, in July 2008. Concrete commitments or pledges as the result of the meeting were shared with the participating countries for their implementation. As indicated by Yudhoyono, Indonesia would offer capacity building opportunities to 1000 Palestinians over five years, from 2008 to 2013 (Kemlu, 2011b). Indonesia exceeded this commitment. Yudhoyno, in his opening speech at Jakarta's March 2014 Conference on Cooperation among East Asian Countries for Palestinian Development (CEAPAD II), stated that 1200 Palestinians had participated in Indonesia's program on capacity building for Palestine in the period of 2008-2013. Taking into account the success of the program, Dr Marty M. Natalegawa, Indonesia's Foreign Minister (2009-2014), declared in his annual press statement dated 7 January, 2014, that:

"As the program for Palestine capacity building for the period of 2008-2013 under the framework of the New Asia Africa Strategic Partnership comes to an end, we will be launching the next phase of capacity building program for the period of 2014-2019. Furthermore, Indonesia as the host of the Conference on Cooperation among East Asian Countries for Palestinian Development (CEAPAD), Indonesia will galvanize support for such program from countries in Asia" (Natalegawa, 2014, p. 7).

CEAPAD was an initiative spearheaded by Indonesia and Japan. Through this forum, Indonesia has had an interest in urging East Asian countries to support Palestine. The forum aims at helping to bring about peace between Palestine and Israel through the twostate solution. The participating countries have been urged to come up with concrete contributions to Palestine's nation-building efforts (Fardah, 2015).

Indonesia has also tried to demonstrate its support for and solidarity with Palestine utilising the NAM. Along with 12 NAM Ministerial Committee for Palestine, Natalegawa intended to hold a special meeting in Ramallah on 5 August 2012. Aside from showing solidarity with Palestine, they wanted to ascertain the situation on the ground and the effects of Israeli policies. Natalegawa argued that Israel's actions were against the principles of international law and its obligations as an occupying power. The committee also condemned Israel and stated that its actions had provided strong reasons for the committee to help Palestine realise its statehood (Kawilarang, 2012). The meeting was 
widely reported to the Indonesian public, and Natalegawa was praised by Muslim groups. His actions, together with his NAM fellows, were seen by Al Muzammil Yusuf from PKS as an indication of the government's commitment to supporting Palestine (interview with Al Muzammil Yusuf, 26/11/2013).

Led by its interest in projecting an international reputation as peace-maker and Muslim leader (Yudhoyono, 2005), and partly driven by domestic politics (Greenlees, 2007), Indonesia revealed its accommodative policy in relation to Muslim concerns by proposing to initiate Hamas-Fatah reconciliation talks in August 2007. However, this meeting was not realised due to unexplained reasons. Although the country's efforts were unsuccessful in bringing about unity between Fatah and Hamas, Yudhoyono's regime had succeeded in imparting the message that his government had done its utmost to help Palestinians. The government's peace initiative was welcomed by Muslim society although their hope had been for more than that. Mahfudz Siddiq, a politician from PKS and chairman of Commission I of DPR argued that Muslim society had expected the government to play a greater role in the Fatah and Hamas talks, and in the Palestinian-Israeli peace settlement in general. As a result of his meeting with PM Ismail Haniya in Gaza and with President Mahmoud Abbas in Ramallah, Shidik observed that the two factions expected Indonesia to participate in reconciliatory efforts for the unification of Fatah and Hamas (interview with Mahfudz Siddiq, 25/11/2013).

In fact, Indonesia did not lack an interest in participating in the Middle East conflict. This desire can be seen in its convening of the Sunni-Shiah conference in April 2007, to help ease sectarian conflict in Iraq (Murphy, 2009), being engaged in the 2007 Annapolis Conference, and sending UN peacekeepers to Lebanon. However, the country's interest in playing a bigger role in the peace settlement in Palestine has been constrained. It means that Indonesia has had limitations with regard to playing a more important role in the Middle East. This constraint is related to Indonesia's non-recognition policies toward Israel and hostile reactions from the public on issues related to its potential diplomatic relations. Such circumstances are a dilemma for the country's policy-makers as they attempt to manage the balance between ambition and restraint.

Yudhoyono's administration opted to refrain from establishing diplomatic relations with Israel, instead pursuing its desire to become a direct peace broker between Palestine and 
Israel. Since ascending to power in November 2004, Yudhoyono's government was not free from rumours that it might establish relations with Israel. Mark Regev, a spokesman of Israel's Foreign Minister, stated that his country had sent messages to Indonesia expressing Israel's desire to initiate diplomatic relations (Xinhua, 2005). However, Natalegawa, who was the spokesperson of the Indonesian Ministry of Foreign Affairs, hastily denied that such a message had been received. Natalegawa made a statement arguing that "there has been no such communication with Indonesia. Please note, there are no diplomatic relations between the two countries, so it is hard to imagine that such a communication could be made," (BBC, 2005).

Muslim groups and legislators brought their concerns about a meeting between Wirajuda, Yudhoyono's Foreign Minister between 2004-2009, and Silvan Shalom, Israeli Foreign Minister, to the margins of the 2005 World Summit (Purba, 2005). Commission I of DPR, for example, sought clarification from the Minister for Foreign Affairs. Wirajuda's explanation to DPR at their hearing on 30 November, 2005, revealed that contact had been requested and initiated by Israel. Indonesia obviously gained benefits from the contact, however, as the country aspired to be involved in peace settlements in the Middle East. This aspiration was not merely in the interests of Indonesia, but also met expectations from the Palestinian perspective (Deplu, 2005).

The meeting between Wirajuda and Shalom ended without results as both countries returned to their old arguments. For Indonesia, its involvement in seeking a peace settlement was intended to help the Palestinians to have their rights. With this meeting, the government sought to test public reactions. As Wirajuda observed, the public reaction, largely stemming from Muslim groups, was generally positive taking into account this was a sensitive issue. It meant that the public did not totally negate 'the need to contact Israel', so long as the country did not recognise or initiate diplomatic relations. The public might start to be aware that contact was necessary to help realise the bigger mission: helping the Palestinian people (Deplu, 2005).

Once again we see that Indonesia's aspiration to be involved in the Palestinian-Israeli peace settlement was hampered by the country's non-recognition policy and the absence of diplomatic relations with Israel. In seeking to overcome this problem, Marzuki Darusman, a Member of the Indonesian Parliament from the Golkar Party, proposed a controversial 
proposal to open diplomatic relations with Israel. His statement triggered harsh reactions from fellow legislators in DPR. Abdillah Thoha, an MP from PAN, for example, slammed Marzuki's proposal by saying "It makes no sense to establish ties with Israel because the preamble of the 1945 Constitution bans us from opening diplomatic ties with any occupying country" (Xinhua, 2006d).

In fact, the parliament has increasingly functioned as a watchdog over the government and its members, in order to ensure that both the government's policies and the attitude of members of parliament do not harm the feelings of Indonesian people, especially the Muslim community. In general, legislators or members of parliament have similar views to the people and the government on the Palestine issue. They have made sure that Indonesia holds true to its basic principles, namely non-recognition of Israel and refraining from diplomatic relations with it. After careful observation of sources regarding working meetings between Commission I of DPR and Yudhoyono's Ministers of Foreign AffairsN. Hassan Wirajuda (2004-2009) and Marty Natalegawa (2009-2014) - it may be concluded that, in general, members of parliament in Commission I, both from nationalist and Islamic parties, have great concerns about the fate of the Palestinians. Members of parliament with such concerns can be found in all factions of $\mathrm{DPR}^{9}$. Solidarity with Palestine has been explicitly demonstrated by DPR leadership. Both Speakers of the DPR, Agung Laksono (2004-2009), and Marzuki Ali (2009-2014), stood behind DPR's initiatives on Palestine. The head of the Council of Inter-Parliamentary Cooperation (BKSAP), Abdillah Thoha (2004-2009), and his successor Hidayat Nurwahid (2009-2014) who was also former Speaker of MPR in the period of 2004-2009 have also demonstrated their strong support for Palestine (Al Muzammil Yusuf, interview, 26/11/2013). Nationalist parties generally based their concerns on the 'constitutional argument', which draws attention to the claim that the Palestinian people have been colonised by Israel. Meanwhile, Islamic parties, especially PKS, have expressed the same constitutional argument, although at the same time they are still driven by Islamic sentiments, as admitted by Al Muzammil Yusuf during an interview with the author (interview, 26/11/2013).

\footnotetext{
${ }^{9}$ The fraksi atau faction is a group in the house of representative (DPR) consisting of a number of MPs who share the same ideology and general position, who are normally from one party. Therefore, factions have been formed according to political party names such as the Golkar faction, PKB faction, PAN faction, and PKS faction.
} 
Spearheaded by Speaker Agung Laksono from the Golkar party, an Indonesian Parliamentary Caucus for Palestine was established in 2006. As part of its actions, the caucus - led by Al Muzammil Yusuf - issued a petition, urging the government to take a mediation role on the Palestinian question. The caucus held a Palestinian solidarity week and attended an international conference on Palestine. The caucus rejected the Israeli parliament's participation in the Inter Parliamentary Union (IPU) meeting in Bali from April-May, 2007, and demanded the discharge of Palestinian MPs detained by Israel (Rusla, 2007).

To further affirm DPR's support for Palestinian statehood and to reveal its commitment to voicing Muslim groups' concerns on Palestine, the Group of Bilateral Cooperation between Indonesia and Palestine (GKSB) was established on 5 December, 2012 (Ramadhan, 2012). The group, led by Al Muzammil Yusuf, constitutes a formal organ of DPR which is specifically intended to enhance cooperation with the Palestinian parliament and to help Palestine's struggle (Al Muzammil Yusuf, interview, 26/11/2013). Like the government, DPR has set the Palestinian issue as its main agenda. The Seventh Parliamentary Union of the Organization of Islamic Cooperation (PUIC) Conference in Palembang, Indonesia, in January 2012, adopted a recommendation to support Palestinian independence. As proposed by Indonesia, the conference also agreed to send a delegation to Gaza consisting of speakers of the OIC parliamentary countries, in order to push for an end to the Gaza siege (Purwadi, 2012). Although the delegation has not yet been realised, this initiative has been seen by domestic constituents and international society as part of Indonesia's efforts in supporting Palestinian statehood.

Amidst DPR's efforts to ensure Indonesia's solidarity with Palestinians, the public was surprised by the visit to Israel of Tantowi Yahya, an MP from the Golkar faction, and five of his entourage from the media, universities, and think tanks. The visit, by invitation of the Australian-Jewish Association, was made secretly in early June, 2013. The public found out about the visit after Israeli media outlet Israel Hayom reported the visit with the title "High ranking Indonesian delegation secretly visits Israel" (Waskita, 2013). Tantowi's visit received a harsh response from Muslim groups In Indonesia. They believed that Tantowi had betrayed the nation and offended Muslim people. Criticism came from both moderate and militant groups such as Muhammadiyah, NU, Indonesian Ulema Forum (FUI), MUI, PKS, and FPI. Among the strongest reactions were those from the head of 
FPI, Habib Rizieq, who called Tantowi an idiot when he tried to argue that Israel is not at war with Islam. He demanded that Tantowi be fired from DPR and from the Golkar party (Kiblat, 2013).

After receiving an official complaint from Muslim groups, the Honorary Council of DPR (BK-DPR) summoned Tantowi Yahya to discuss his actions. Eventually, Tantowi publicly apologised to Muslim society (Tribunnews, 2013). Muhammadiyah then called on him for further clarification on 23 June 2013. He explained his visit and affirmed his support for Palestine (Maruli, 2013). Although they may be seen as a trivial issue, visits to Israel have the potential to be highly sensitive issues when undertaken by officials, members of parliament and other state apparatus, as well as activists from Muslim organisations.

\section{Palestinian statehood and Indonesia's support}

Indonesia has been at the forefront of efforts to support Palestinian aspirations. This consistent position was demonstrated by Sukarno at the 1955 Asian-African conference, and by Suharto's quick decision to recognise Palestine as a state on 16 November 1988, 6 six hours after PNA had declared its independence. This commitment continued with the opening of diplomatic relations with PNA on 19 October 1989, and the welcoming of the first Palestinian ambassador to Indonesia, who conveyed his credentials on April 23, 1990. Since then, Indonesia has contributed funding to rent the embassy building and to help run the embassy's operations in Jakarta. In exchange, Indonesia has assigned its ambassador in Amman, Jordan to be accredited to Palestine (Deplu, 2004).

In 2005, Yudhoyono revealed his personal interest in visiting Palestine. In April Indonesia was asked to play more pivotal role in the peace process in the Middle East during the Asian-African Summit in Jakarta (Jakarta-Post, 2005). Yudhoyono's gesture to visit Palestine may have been a means of demonstrating his government's commitment and solidarity towards Palestinians. However, he was undoubtedly aware that his visit would not be easy to organise as Palestinian territory is under the control of Israel. It was important for Yudhoyono to show his sympathy to the plight of Palestinians. He also seemed determined to indicate his strong commitment regarding Palestinian independence to members of his government coalition from Islamic parties (Sabri, 2012). 
Among contemporary Indonesian political parties, PKS has constituted the most prominent political party showing great concern about world politics, particularly regarding the Palestinian question. Solidarity towards Palestinians has become a main theme of its political campaign and of its party's discourse on international issues (Hasan, 2011). As a savvy leader, Yudhoyono was aware of the need to draw support from his coalition and his voters, who regarded the Palestinian issue as sensitive one. Al Muzammil Yusuf, an MP from PKS, told the author that commitment to supporting the independence of Palestine was a part of PKS's political contract with Yudhoyono before forging their political coalition. He observed that Yudhoyono had demonstrated his commitment to undertaking this political contract (interview with Al Muzammil, 26/11/2013).

Indonesia's interest in being involved in the Palestinian-Israeli conflict did not come about in isolation from the wider international system. Its involvement depended on whether or not there was an offer to be involved in resolving the conflict from Arab states and Israel. Indonesia hoped to be granted such an offer. It was difficult for Indonesia to directly engage in the peace process without the involvement of key states in the region such as Egypt and Jordan. Indonesia was aware that it had a relatively small chance of becoming a peace mediator in the Palestinian-Israeli conflict, except if Arab states requested Indonesia to do so and Israel allowed Indonesia's involvement (Deplu, 2004).

Since the inception of his administration, Yudhoyono considered assigning a special envoy to Palestine, based in Ramallah. This idea stemmed from intentions to support a peaceful settlement of the Palestinian question through a roadmap that was agreed upon by the Quartet on the Middle East, made up of the US, the EU, Russia and the UN (Kemlu, 2006). This idea was further developed by discussions regarding the establishment of an Indonesian consulate in Ramallah which had been unanimously supported by DPR. But Indonesia apparently recognised the challenges which would be associated with this idea. The absence of diplomatic relations with Israel had become a major obstacle, as thenForeign Minister Wirajuda observed in an open hearing with the Commission I of DPR in March 2006: "The biggest stumbling block facing Indonesia is a requirement of prior approval from the Israeli government, whereas Indonesia doesn't have diplomatic ties with Israel"(Xinhua, 2006c). 
The idea of a consulate did not become a public issue until Yudhoyono's second term. At that time, pressure and suggestions by DPR on the necessity to establish Indonesian representative in Palestine tended to be stronger forcing the government to give a concrete response. This concern was expressed by Foreign Minister Natalegawa during his meeting with the Palestinian Foreign Minister Riyadh Maliki at the sidelines of the third Bali Democracy Forum on December 10, 2010. Natalegawa saw the need to enhance relations between the two countries by setting up Indonesian representation-Natalegawa used the term of 'foothold' to refer a possible Indonesian representative/office-in Palestine in the form of a diplomatic or consular mission in Ramallah (interview with an Indonesian MFA official, 19/09/2013). DPR termed the planned representative office as an 'embassy and consulate'. Legislators in DPR used the two terms interchangeably. In an opening speech in Bandung to the July 2012 International Conference on the Freedom of Al-Quds and Palestine, speaker Marzuki Alie argued that "to demonstrate our recognition of the Palestine State, we need to open a consulate in Ramallah" (Antara, 2012a). Meanwhile, Al Muzammil Yusuf had used the term 'embassy' when he urged the government to establish its mission in Palestine despite the absence of diplomatic relations with Israel (Aritonang \& Santosa, 2012).

Both the government and DPR hoped to achieve the ultimate goal of opening an embassy in Palestine. However, the government tended to be realistic, as it knew the challenges in pursuing such a development. Therefore, despite pressure from legislators, the Ministry of Foreign Affairs decisively stated that it would be difficult to open an embassy in Palestine. Foreign Ministry spokesperson Michael Tene said: "Indonesia has been a strong supporter of the Palestinian people in various aspects, both bilaterally and multilaterally. In principle, of course, we would like to have an embassy there, but implementation would be very difficult. Palestine is still an occupied territory" (Yu, 2012). Previously, PAN and PKS had issued a document supporting the establishment of an Indonesian embassy in Palestine. This was a result of their meeting with Sheikh Abdurrahman, the deputy chairman of the Palestinian parliament (Yu, 2012).

The plan of establishing a representative office in Palestine eventually found a workable form, namely the appointment of an honorary Indonesian consul to Ramallah. This is the most realistic effort that Indonesia has managed to make. Dino Patti Djalal, an Indonesian ambassador to the US who acted as Yudhoyono's special envoy, met President Mahmoud 
Abbas in Ammman, Jordan on 28 February, 2012. Djalal conveyed a letter to Abbas from Yudhoyono, which, among other things, mentioned Indonesia's plan to appoint an honorary consul in Ramallah (interview with a foreign affairs official, 19/9/2013). The process of appointing this envoy has been continued by President Joko Widodo's administration (which gained power after Yudhoyono finished his presidency in October 2014). The commitment has been reaffirmed by Foreign Minister Retno L. Marsudi when delivering her first annual press statement in January 2015, saying that "in order to forge a closer relationship to Palestine, Indonesia will establish an Honorary Consulate in Ramallah in the near future to complement its embassy accredited to Palestine based in Amman, Jordan" (Marsudi, 2015, p. 8).

With regard to Palestine's statehood, Indonesia has embraced the two-state solution based on the 1967 border line, with East Jerusalem as Palestine's capital. Indonesia has always favoured the Palestinian side. This support was reaffirmed by President Yudhoyono when receiving a Special Envoy of President Mahmoud Abbas, Nabeel Shaath, in August 2007 (Deplu, 2007) and in telephone talks with President Mahmoud Abbas during his visit to Jordan on 3 May 2006 (Wijaksana, 2006). During Yudhoyono's presidency, President Mahmoud Abbas visited Indonesia twice: in October 2007 and May 2010. Aside from expressing its support for Palestine, Indonesia emphasised the importance of unity among Palestinian factions. The internal rift between Hamas and Fatah has prompted concerns on many sides in Indonesia, including the government, legislators, and activists of Muslim groups. Interviewees frequently highlighted this problem, and expressed their concern about it. They believed that internal rifts between Palestinian politicians will only benefit Israel. Disunity could, they believe, cause more grievances for Palestinians under Israeli control, and could make it even more difficult to realise an independent state of Palestine.

With regard to Palestine's bid for international organisational membership under the UN, Indonesia frequently became a co-sponsor. For example, Indonesia together with a number of countries co-sponsored UNGA resolution 67/19 which conferred Palestine with a nonmember state status. Before the Assembly on 29 November, 2011, Foreign Minister Natalegawa stated that:

"There can no be reason, therefore, why the international community cannot endorse the request to accord Observer State status to Palestine. An entity that some 24 years ago the Assembly, through its resolution 43/177, acknowledged as a State. Indonesia is thus a co-sponsor of the resolution before the Assembly. 
And we reiterate the hope that Palestine's application to full membership in the United Nations will be favourably considered" (Natalegawa, 2011).

Natalegawa also rejected the argument of Israel that the Palestinian authority's unilateral act would jeopardise existing peace talks with Israel. He said that "we have been emphasizing to all parties including the Quartet that the Palestinian step is not unfriendly towards negotiations process but on the other hand is aimed at encouraging the process"(Antara, 2011a). He also appeared to justify Palestine's step, saying that "this has shown how the Palestinians have been forced to take a choice after no progress has been made in the peace process. Priority however remains to be put on the peace process and its hoped through this effort the process could be revived again," (Antara, 2011b).

The Palestinian authority's bid for the UN membership was promoted by Indonesia to Non Aligned Movement countries. Taking advantage of being the host of the $16^{\text {th }}$ NAM Ministerial Meeting in Bali, from 23-27 May, 2011, Indonesia proposed an action plan for Palestinian recognition. This action plan was intended to assist NAM's efforts to garner international support for recognition of Palestine as a state and to support Palestine's efforts to be admitted as a member of the UN. This initiative was discussed by thirteen members of the NAM Ministerial Committee for Palestine. The plan of action prompted each committee member to approach states in their respective regions which did not recognise Palestine as a state (Kemlu, 2011a). The country's initiatives were rewarded with a great result. From the time of the $16^{\text {th }}$ NAM in Bali through the plan of action proposed by Indonesia, the NAM countries that recognised Palestine increased from 113 in May 2011 to 132 in November 2012 when the UN voting was held (Kemlu, 2012b).

In the lead up to Palestine's bid for UN membership, Indonesia's Foreign Minister was as busy as the Palestinian delegates. He held meetings with the Palestinian Committee at the UN on 22 September, 2011, and the OIC ministers the next day in New York. He also held a bilateral meeting with Kazakhstan Foreign Minister Yerzhan Kazykhanow, the chairman of the OIC at ministerial level. Natalegawa's efforts were to ensure international support and solidarity on Palestine statehood (Antara, 2011a). Natalegawa used the sidelines of UNGA sessions to hold meetings for the sake of Palestinian statehood. A ministerial forum of some developing countries, namely Brazil, India, South Africa and Indonesia was also held to find a way to help solve the Israeli-Palestinian conflict. 
Natalegawa wanted to demonstrate Indonesia's commitment to supporting Palestine through any possible forum (Antara, 2010).

The government proceeded hand in hand with the parliament when it came to supporting the Palestinian bid at the UN. Along with Natalegawa, Vice Chairman of DPR's Commission I, Hayono Isman, and his fellow member Luthfi Hasan Ishaq were present in New York on 23 September, 2011 (Prasetyo, 2011). Prior to the US veto of Palestine's full membership bid to the UN, prominent leaders of Indonesian Muslim groups expressed their hopes and concerns about the Palestinian bid (Prasetyo, 2011). Their concerns echoed the government's fear about the US stance and the probability of it exercising its veto rights. Muhammadiyah's chairman, Din Syamsuddin, for example, had raised his concerns that the US would use its veto to curb Palestinian independence efforts. Acording to Din Syamsuddin, the veto would only strengthen the US's double standard image and made Obama's speech in Cairo irrelevant and void. Similarly, Hasyim Muzadi, a former chairman of the NU, argued that the US veto would reflect the inconsistencies of its status as a human rights advocate. He urged the Indonesian government to uphold the anticolonialist values of the 1945 Constitution and to fight against global injustices like those that have taken place in Palestine. According to Hasyim Muzadi the Indonesian government was obliged morally to undertake such a fight for Palestinian statehood. The International Conference of Islamic Scholars (ICIS) which Hasyim Muzadi has initiated also often holds forums for the sake of discussing Palestine's struggle (Prasetyo, 2011).

\section{The Gaza wars: Muslim groups' reaction and the government's response}

A series of Israeli incursions occurred after Hamas's election victory in March 2006. The first major Israeli incursion into Gaza, carried out under the name 'Operation Summer Rains', started in June and ended in July 25, 2006. It killed 394 Gaza residents, the majority of whom were civilians, including 26 children. This operation was followed by 'Operation Autumn Clouds', launched on November 1 and ending on 26 November 2006. A complete ceasefire between Israel and Hamas only occured when the Hamas-Fatah conflict escalated in 2007 (Bickerton \& Klausner, 2010). The second major Gaza war took place from December 2008 to January 2009, and 1417 people lost their lives in the conflict, including 236 fighters. This Israeli incursion, dubbed 'Operation Cast Lead', badly hit Gaza from air, land, and sea (Filiu, 2014). Israel made another incursion in November 2012, using the code Operation 'Pillar of Defense', bombarding Gaza and 
causing 166 Palestinian fatalities, most of them civilians. The last attack happened in July 2014. If the first three wars were intended to punish Gaza for its opposition, the last war was allegedly intended to sabotage the reconciliation between Hamas and Fatah (Filiu, 2014).

As Palestine's fate had become the concern of many sections of the Indonesian public and government, it was not surprising that protests occurred in the country over the Palestine issue. The strongest voices in these protests were Muslim groups, both moderate and militant. Both types of Muslim group have had different ways of expressing their aspirations. Militant Muslim groups have often utilised theological arguments and religious jargon. Responding to the 2006 Israeli incursion in Gaza, for example, radical Islamic cleric Abu Bakar Baashir urged the dispatch of Islamic holy warriors (mujahidin) to Israel to punish the country for its brutal acts against Palestine. He said that "Israel is the enemy of Allah, that is why Indonesia should send holy warriors there" (Telegraph, 2006, p. 2). Meanwhile tens of thousands of tarbiyah (cadres) and supporters of PKS staged a rally in Jakarta to show their support for Palestine, collecting Rp. 700 million (about US\$80,000). PKS had launched 'a one man, one dollar campaign' for Palestine. Aside from condemning the acts of Israel, they demanded the removal of an economic boycott by certain Western countries following the victory of Hamas in the Palestinian election (Jakarta-Post, 2006b).

The economic boycott and incursion of Israel towards Gaza, as well as the Israeli attacks on Lebanon, took place almost concurrently in 2006. Not surprisingly, Indonesian Muslim groups also urged the government to send troops to Lebanon. This demand was similar to the result of the OIC emergency meeting in August 2006 which called for an immediate ceasefire in Lebanon and a role for Muslim countries in a peacekeeping force under the UN banner (Fernandez, 2006). Israeli Prime Minister Ehud Elmert rejected the involvement of peacekeeping forces from countries that did not have diplomatic relations with Israel. Despite Israel's position, the UN resolution mandating the formation of a 15,000 strong peacekeeping force in Lebanon to help end the conflict between Israel and Hezbollah did not explicitly grant Israel the power to obstruct countries from participating (Nessman, 2006). Din Syamsuddin from Muhammadiyah condemned Israel's rejection of Indonesia and Malaysia's participation in the UN Interim Force in Lebanon (UNIFIL), and FPI requested that the government facilitate the two countries' presence in Lebanon 
(Priyambodo, 2006). While rejecting calls to facilitate jihad for militant Muslim groups, the government appeared to accommodate their concerns in part, sending peacekeepers in relatively large numbers to Lebanon. Indonesian troops have worked alongside other countries' peacekeeping forces under the banner of the UN Interim Force in Lebanon (UNIFIL) up to the present day (Muttaqien, 2013).

Along with nationwide rallies condemning the second Israeli incursion at the end of 2008 to early 2009, a number of militant groups such as HTI and FPI wished to send volunteers to Gaza for the sake of jihad, and sought the government's support (Hotland \& Khalik, 2009). The government refused their request as sending such volunteers would not improve the situation and would not meet the true needs of Palestinian people. Officials argued that what Palestinians needed most was medicine and medical assistance, and gathered volunteer medical workers (BBC, 2009). However instead of observing the government's suggestion, the radical groups decided to rally their own volunteers. Their attempt to send 200 volunteers to reach Palestine via Batam-Johor Bahru-Kuala Lumpur was thwarted by authorities in Indonesia, Malaysia and Thailand (Nhina Le Thi, 2009).

During the 2009 Gaza war, Indonesian TV channels bombarded viewers with coverage of the Israeli attacks, indicating brutality had occurred. Likewise, newspapers were flooded with the same news and rallies by Muslim groups in Indonesia to protest Israel. The rallies were held in Jakarta, Serang (Banten province), Gresik and Malang (East Java) and Banda Aceh (Aceh). Around 200 students and members of Muslim groups rallied at Sultan Ageng Tirtayasa in Serang. The demonstrations that were held in Gresik and Banda Aceh were spearheaded by the KAMMI. They demanded the government take a harsh stance against Israel and called for the UN to impose sanctions on Israel (Jakarta-Post, 2008b).

Meanwhile, HTI staged protests not only in Jakarta but also in other regions around the country. In Jakarta, HTI held demonstrations in front of the US Embassy on 30 December, 2008 (Yunanto, 2008). Two days later it was PKS's turn to stage a demonstration for the same purpose. Thousands of its cadres and supporters crowded main streets in Jakarta and subsequently headed to the US Embassy (Suwarjono \& Nugraheni, 2009). Rallies were not only conducted by militant groups, but also moderate Muhammadiyah and its supporters in Jakarta and other cities. Thousands of Muhammadiyah supporters in Yogyakarta, for example, staged a demonstration to condemn Israeli aggression in Gaza. Meanwhile, 
Muhammadiyah Youth, together with other Muslim groups such as HTI and tarbiyah of PKS, rallied in Malang, East Java. Perhaps the strongest voice was expressed by Muhammadiyah Youth when staging a rally in Jakarta, urging the US Ambassador's deportation as the US has been a main backer of Israel (Widjaya \& Huda, 2009).

A different attitude was expressed by another moderate Muslim group-NU-in its protests against Israel. NU did not appear to rally in the streets as other Muslim groups had, instead it issued a statement containing a number of points. First, NU condemned the Israeli attack on Gaza and called for international society to regard Israel's acts as war crimes. Second, NU urged United Nations member states to take concrete measures to halt Israeli acts and call for the UN to impose sanctions on Israel. Third, NU called for the unity of all Palestinian factions. Fourth, it appealed to the government of Indonesia to continue with its humanitarian aid to Palestine, and to send peacekeeping troops under the UN banner. Finally, the group instructed all NU special branches in the Middle East and Africa (such as in Egypt, Jordan, and Syria) to take necessary actions to help the Palestinian people (PBNU, 2009).

The government of Indonesia condemned the Israeli assault on Gaza, saying it had led to humanitarian crisis, and urged Israel to respect international law, humanitarian law and human rights law. As a member of the UN Human Rights Council (HRC), Indonesia pushed for a special session of the Council from 9-12 January 2009, to address the Gaza crisis. Indonesia, through the Non Aligned Coordinating Bureau in New York, also initiated the holding of a special session of the UNGA on 15-6 January 2009 (Kemlu, 2014). This initiative was precipitated by President Yudhoyono's disappointment when observing the slow response of the UNSC and Israel's disdain for the UNSC resolution (Jakarta-Post, 2009). Yudhoyono then approached French President Nicolas Sarkozy and Syrian Prime Minister Mohammad Naji Otri about pushing Israel to comply with the UNSC resolution and asking for a second UNSC resolution. However, after the UNGA passed Resolution No. A/RES/ES-10/18 supporting the implementation of UNSC resolution 1860, and called for the international community to help overcome the humanitarian crisis in Gaza, Indonesia was again disappointed and abstained, arguing that the UNGA resolution was not strong enough to condemn Israel (Lacey, 2009). 
Aside from diplomatic efforts, Indonesia also gave donations for the building of an Indonesian Cardiac Facility at Al Shifa hospital in Gaza, sent US\$1 million in cash, supplied medical aid worth around US\$179,000 (Hendropriyono, 2009), and dispatched medical workers and other volunteers for humanitarian purposes. Prior to that, Indonesia had contributed US\$1million for Palestinian humanitarian aid, fulfilling its pledge at the Paris Donors' Conference of 17 December 2007. Other commitments included its annual contribution to the United Nations Relief Works Agency for Palestine in the Near East (UNRWA), amounting to US\$20,000. By 2012, Indonesia had delivered US\$100,000 to this organisation (interview with an Indonesian MFA official, 19/09/2013). Indonesia also donated US\$100,000 for Palestinian refugees at the border of Gaza and Egypt as a result of the Hamas-Fatah conflict in 2007 (Deplu, 2007a).

Besides the humanitarian assistance stemming from the Indonesian government, Muslim groups and other organisations from Indonesia had also been actively involved in responding to the 2009 Gaza crisis. These included the Komite Indonesia bagi Solidaritas Palestina (Indonesian Committee for Palestinian Solidarity-KISPA), the Medical Emergency Rescue Committee (Mer-C), PKS, and Muhammadiyah. PKS, for example, provided medical assistance to Gaza, and Muhammadiyah sent six medical surgeons and supplied medical and logistical items (Hendropriyono, 2009). The Mer-C team succeeded in entering Gaza on 17 January, 2009, after waiting for two weeks on the border. Mer-C has since built an Indonesian hospital in Gaza. During an interview with the author on 5 January 2014, Mer-C president, Joserizal Jurnalis explained that the hospital has been funded entirely by the donations of Indonesian people, without any assistance from the Indonesian government or any foreign funding. Meanwhile, KISPA and FPI have frequently sent aid and volunteers to Palestine, both in times of war and under more peaceful circumstances. In times of war, however, FPI also wishes to send volunteers for jihad, fighting against Israel.

Harsh reactions have come from moderate and militant Indonesian Muslim groups, senior high school students, and university students in relation to the Israeli incursion to Gaza in 2012 and 2014. With a boom in the number of social media users in Indonesia from mid2009, news of the Israeli incursions was easily spread among Indonesian people. Through social media, users condemned Israel, and with their Facebook statuses or tweets often accessible to other users, people around the country and around the world would see their 
messages. Social media has also been an effective medium to find support and to organise rallies and demonstrations.

As such, rallies and demonstrations protesting Israel's attacks on Gaza became more widespread, occurring not only in Jakarta but also in other Indonesian regions. A Senior High School in Solo, for example, expressed their protest through a mass prayer and poetry reading calling for peace in Palestine (Wismabrata, 2012). PKS and FPI provided volunteers to be sent to Gaza. Meanwhile, HMI, KAMMI, and students in various universities also staged rallies protesting Israel's acts. Thousands of students at the Islamic boarding school (pesantren) of Miftahul Huda in Tasik, a small city in West Java province, also held a demonstration (Nugraha, 2012).

Muhammadiyah and NU had also condemned Israel's attacks and criticised the tardiness of the UN in handling the crisis in Gaza. The Association of Indonesian Muslim Intellectuals, which had played an important political role in ending Suharto's regime, demanded the government send peacekeeping forces to Gaza, while HTI demanded the government send armed forces to Palestine. LazisMu-a charity organisation of Muhammadiyah which collects zakah and shodaqoh (charity) from Muslims - has plans to build a school in Gaza (Muftisani, 2012). Muhammadiyah also plans to build child centres for Palestinian children. Dompet Duafa, an Islamic charity foundation, has also built 10 schools in Gaza (RIB, 2014). In the present day, many more Indonesian charity organisations have allocated their charity funds to Palestine, such as Badan Zakat Nasional (National Zakat Board-Baznas), and LazisNU—a charity organisation of NU. LazisNU held fundraisers for the Palestinian people throughout Indonesia in the aftermath of the Israeli incursion into Gaza in 2014 (Agung Sasongko, 2014).

In 2012, Muslim groups urged Yudhoyono to discuss the Gaza crisis with President Obama at the sidelines of the ASEAN Summit in Cambodia. The president responded favourably to Muslim groups' aspirations. He discussed the issue with Obama at that time (Ratya, 2012). Echoing the voice of its majority population, the government condemned as brutal the acts of Israel during the 2014 Gaza war and called on the UN and other parties, in particular the US, to take necessary actions to halt the conflict (Hernawan, 2014). Indonesia also sent US\$1million to Palestine to show the country's solidarity in the aftermath of the Israel incursion in 2014 (Tombeg, 2014). Aside from the government, 
Muslim groups, students, and public at large, and members of DPR also demonstrated their support by visiting Palestine. Speaker Marzuki Ali (2009-2014), for example, visited Palestine twice (Al Muzammil, interview, 26/11/2013). In responding to the Gaza wars in 2009, 2012, and 2014, DPR especially Commission I sent delegations to Gaza. The delegates usually met the Palestinian parliament, PM Ismail Haniya in Gaza, President Mahmoud Abbas in Ramallah, members of the population, and also delivered humanitarian aid. Only in 2014 did the delegates of DPR fail to enter Gaza, although they had arrived in Egypt. The Egyptian authority did not grant permission for the delegates of DPR to enter Gaza from the Egyptian territory (Makyanie, 2014).

\section{Conclusion}

The above discussion demonstrates that both governmental policy and public opinion, particularly that among Muslim groups, are generally aligned, and that some efforts in humanitarian aid have even been mutually reinforcing. The Palestinian issue has been shown to unite different Muslim groups with both the government and the parliament. Despite some different attitudes and reactions among militant and moderate Muslim groups, their fundamental views on Palestine align. They believe that the Palestinians have long been under the suppression of a colonialist Israel, that their rights have been violated and ignored by Israel, and that the Palestinians have suffered persistent injustices due to Israel and its Western supporters, especially the US and the UK. Muslim groups generally also argue that international society, especially in the UNSC, does little to solve the Palestinian question and they believe that the UN members do not do enough to force Israel to comply with UNSC or UNGA resolutions on Palestine. Muslim groups generally view that the US, as an advocate of human rights promotion, has applied a double standard when it comes to Israel's attitude and actions. These views have generally been shared by the Indonesian government and parliament.

The basic argument behind the Indonesian government's policy towards Palestine is a constitutional one, in which the country's constitution has mandated the abolition of all forms of colonialism. Israel is viewed as a colonist in the Palestinian territories. Therefore, the Indonesian government views that the prominent problem of the Palestinian issue has been related to territorial problems, injustices, human rights violation, and humanitarian crisis. As such, it is obvious for Indonesia to which side its support should go. This constitutional argument has also been adopted by a range of different Muslim groups, both 
moderate and radical. However, aside from the main problems perceived by the government, Muslim members of the population tend to share the belief that the conflict between Israel and Palestine is largely related to religious sentiments, specifically a conflict between Islam and Judaism.

It is my conviction that both moderate and radical Muslim groups have perceived that the problems of the Palestinian question have been also related to religious sentiments. However, only militant Muslim groups have admitted it openly, while moderate Muslim groups tend to avoid using religious sentiment in their public statements. Even the Islamist party PKS — whose cadres and supporters adhere to a militant religious attitude — has not always been so blunt in its statements to argue that the Palestinian question is related to religious sentiments. The author argues that Muslim groups have, in general, embraced both the constitutional argument and religious sentiment when considering the Palestinian issue. Similarly when looking at political parties' views on this issue, the author tends to agree with Al Muzammil Yusuf - an MP from the PKS faction-when he admits that "nationalist parties have based their reasons on Palestine on constitutional arguments while Islamist political parties based their rationale on both constitutional and religious arguments" (Al Muzammil Yusuf, interview, 26/11/2013).

The Indonesian government has never formally admitted that the Palestinian question is related to religious factors. However since the country's population has a Muslim majority, some of whom perceive that the Palestinian cause has been related to religious issues, the government has apparently tried to accommodate their beliefs and aspirations, as the function of the government is to serve its people. Moreover, these aspirations are broadly in line with the 1945 constitution on which the government has based its own argument. In this vein, I recall the words of Prof. Dr. Bachtiar Effendy-a prominent political scientist in Indonesia-who said during an interview that "the rhetoric that we are using is a constitutional rhetoric. However, this constitutional rhetoric is in line with political domestic sentiment" [that has regarded the Palestinian cause as related to religious issues] (Bachtiar Effendy, interview, 14 October 2013).

In this situation, Muslim groups, especially the moderate ones, are satisfied to only base their reasons on the constitutional argument. They feel that their aspirations have been well considered and accommodated by the government. Practically, their aspirations follow a 
very similar line to the government's policy on Palestine. Indeed, President Yudhoyono's statement that "Indonesia's support was not a policy statement, as much as it was a statement of fact" has found its ground.

Yudhoyono's character as an 'internationalist', which the author defines as a person interested in foreign policy and concerned about international issues, and his commitment to democracy, both influenced the nuances of Indonesia's foreign policy towards Palestine. These personal characteristics brought his foreign policy on Palestine to a stage which was not only reactive in nature but also a kind of activism. This notion opposed Perwita's (2007, p. 98) argument saying that "Indonesia's policy towards the Middle East, [including Palestine] had been reactive in nature". In fact, President Yudhoyono-through his international initiatives - undertook an activist policy towards Palestine and had responded accordingly to Muslim groups' aspirations regarding the situation in Palestine. Yudhoyono's administration remained cautious when dealing with sensitive issues in relation to Palestine, particularly the establishment of diplomatic relations with Israel and any actions that might have had the 'implication of Israel's recognition' such as visits to Israel by Indonesian officials, members of parliament, Muslim groups' leaders or members, or even politicians or journalists attending official Israeli events, particularly Israeli Independence Day celebrations. 


\section{CHAPTER SEVEN \\ CONCLUSION}

\section{Introduction}

This thesis has studied the role of Islam in the contemporary foreign policy of Indonesia, one of the world's most important Muslim majority countries. The author's initial main arguments have been confirmed. First, the influence of Islam on Indonesian foreign policy has been greater than was commonly thought. This increased influence occurs when Muslim groups' aspirations converge with broader political constituencies. Second, the influence of Muslim groups is more noticeable when their aspirations do not threaten national strategic interests.

These two main arguments were set to consider the extent to which Islam has influenced Indonesia's contemporary foreign policy and under what conditions Islam has had that influence. This thesis employed the two-level game approach of Putnam and a statistpluralist (societal) approach of Skidmore and Hudson (1993). The two-level game approach maps out the linkage of domestic and international factors which might emerge in certain selected case studies. Meanwhile a statist-pluralist approach is used to investigate the interplay between the Indonesian government and Muslim groups in Indonesia's post-Suharto foreign policy making.

Overall, this thesis concludes that in the post-Suharto era, in general, Islam has had an increased role in contemporary Indonesian foreign policy. Islamic elements and Muslim groups' aspirations have been increasingly included and accommodated in the country's foreign policy. These accommodations are made on the basis that their aspirations do not contradict fundamentally with Pancasila as the state philosophy, the 1945 constitution, the independent and active principles of Indonesia's foreign policy, and the country's vital national interests, mainly those related to territorial integrity.

Each of the thesis case studies, namely: Indonesia's policies towards the Iranian nuclear program; Kosovo's independence; and Palestinian statehood offers different insights. The case of Iran's nuclear programme shows how the Indonesian government had to deal with foreign policy choices when there were major pressures from Muslim groups. This case also demonstrates whether or not the government entertains the pressures from domestic 
constituents and disregards its diplomatic rational choice and international pressures or vice versa. The Iranian nuclear case tells us how the convergence of Muslim groups' aspirations with broader political constituencies and the level of Muslim groups' pressures influenced the policy options of the Indonesian government.

The case of Kosovo's independence provides a guide to the interplay between Muslim groups and the Indonesian government on an issue which has been perceived by the government as threatening a fundamental national strategic interest: territorial integrity. Meanwhile, the Palestinian case shows Indonesia's dynamic policies on Palestine from the Sukarno to the Yudhoyono's era. This case also reveals whether or not the democratic era has provided more apparent support of Indonesia's support toward Palestinian statehood.

\section{The gradual shift in the features of the relationship between the state and Islam in Indonesia's contemporary foreign policy}

As was demonstrated in Chapter Two, democratisation in Indonesia has undeniably increased Muslim groups' participation in political life. Many Islamic political parties have been established in the post-Suharto era. However, Islamic political parties in general have been outshone by nationalist parties in terms of voting gains in the legislative general elections since 1999. However, this is not to suggest that the Islamic political parties have not received significant votes despite their defeats in general elections.

It can be argued that the majority of Indonesian Muslims have embraced a moderate view in which they have not aspired to the establishment of an Indonesian Islamic state. In doing so, there have been long debates and struggles to formally establish an Islamic state. Even Muhammadiyah and NU, the two Muslim organisations that have been currently championing moderate Islamic views, have struggled to realise an Islamic state in Indonesia in the past. NU and Muhammadiyah channelled their aspirations to include the Jakarta Charter in the 1945 Constitution through Islamic political parties such as the Masyumi party and the NU party. They went hand in hand to achieve the establishment of an Islamic state from prior to independence right up to 1958 during the Constituent Session of the drafting of a new constitution.

However, aspirations to establish an Islamic state have gradually diminished due to the political situation. Efforts to establish a formal Islamic state were crushed during the Sukarno and Suharto periods. Muslim groups' political aspirations were marginalised. In 
expressing their dissatisfaction towards the Sukarno administration, Muslim groups had been suspected of Islamic insurgencies which erupted in many regions in Indonesia. The suspicion of the Sukarno and Suharto regimes towards Muslim politics remained alive until Suharto stepped down.

The Cultural Islam movement which was spearheaded by prominent Muslim intellectuals such as Nurcholis Masjid and Abdurrahman Wahid urged Muslim groups to abandon their aspirations for the establishment of an Islamic state. This movement argues that rather than struggling for an Islamic state, Muslims would be better to strengthen the state with Islamic values. As a result of Suharto's depoliticisation and the Cultural Islam movement, Muslim groups gradually distanced themselves from politics in the era of Suharto and called off their aspirations for an Islamic state.

In the democratic era, some Islamic parties such as PPP and PBB proposed to amend the 1945 Constitution. This proposal was intended to revive the Jakarta Charter. The Charter envisions the implementation of Islamic law (shariah Islam) as an obligation for all Indonesian Muslims. Islamic parties' attempts to revive the spirit of an Islamic state, however, were not welcomed with enthusiasm by Muslims in general.

Chapter Two argued that in the post-Suharto regime, the electoral defeats of Islamic political parties in the general elections have not substantially reduced the significance of the role of Muslim politics in daily life. Islamic and nationalist parties have competed to gain Muslims' votes. Islamic parties, such as PKS, have changed their strategy by avoiding a militant Islamic orientation in their campaigns. The party has promoted universal values such as good governance and anti-corruption rather than sponsoring the establishment of an Islamic state. Meanwhile, nationalist parties have also developed programmes which are in the interest of Muslims, such as Islamic banking and Zakat regulation. Therefore, the author argues that the electoral defeats of Islamic political parties in the general elections have not meant the decline of the role of Islam (analysed here more specifically in terms of the role of Muslim groups) in Indonesian politics. Subsequently, we have not found especially different political platforms among Islamic and nationalist political parties because both Islamic and nationalist political parties have moved to the middle ground to gain Muslims' votes. 
Against this backdrop, it can be argued that Muslim groups have a greater influence on Indonesia's contemporary political life. The increased role of Islam in domestic politics has also brought about a greater role for Islam in Indonesia's foreign policy. Unsurprisingly, the increasing role of Islam has mainly been related to international issues which are of concern to Muslim groups.

After discussing Chapter Two and examining the case studies on Iran's nuclear programme; the recognition of Kosovo's independence; and Palestinian statehood, as well as the interplay between Muslim groups and the Indonesian government in relation to international issues that have become Muslims' concerns as indicated in Chapter Three, this thesis has demonstrated the following points.

First, the democratisation that occurred since the fall of Suharto has brought about different features in the interplay between the government and Muslim groups and other stakeholders in the process of foreign policy decision making. The way Muslim groups have expressed their aspirations and the way the government has responded to Muslim groups' aspirations seems to have shifted. Muslim groups have apparently been more relaxed in conveying their views and, in return, the government's suspicion towards Muslim groups that they would utilise international issues for domestic political purposes has been diminished. Arguably, there has been a perception that PKS has utilised international issues related to Muslim concerns to consolidate their constituencies and to attract voters. However this perception has not led to the assumption that this would endanger national political life and stability. What was perceived as an Islamic threat well known as ekstrim kanan (right extreme) in the Sukarno and Suharto period has not been regarded as a threat since the era reformasi (reform era). In short, the basic tenets of Indonesian foreign policy have remained, but there is a gradual shift from symbolism and rhetoric to more substantive accommodation of Muslim aspirations.

Second, because the government's accommodations of Islamic elements in Indonesia's foreign policy is subject to the state's core policy tenets, the inclusion of Islamic elements in Indonesian foreign policy has not led to dramatic changes. The core policy tenets are derived from Pancasila as the state philosophy, the 1945 Constitution and the country's active and independent foreign policy principles. Aside from these core policy tenets, the accommodation of Muslim groups' aspirations and the inclusion of Islamic elements in the 
country's foreign policy are also subject to their conformity with vital national strategic interests. This thesis chose not to emphasise the ideological aspects of Islam, instead preferring to investigate the role of Islam in political and social movements generated by Indonesian Muslim groups and their interactions with the government in foreign policy formulation and implementation. Should this study have focused on 'ideological aspects' of Islam as a parameter to examine the extent of Islamic influence in Indonesian foreign policy, it would have concluded that Islamic influences have been marginalised, as commonly concluded by other studies in this field, such as those of Sukma, Perwita, Suryadina, and Leifer.

The country's foreign policy is mainly based on Pancasila principles which do not favour any groups or religions. It is believed that Indonesia's foreign policy reflects its national interests in general. It is generally agreed that Islamic motives are not the sole consideration in Indonesia's foreign policy making although Indonesia is a Muslim majority country. Likewise co-religionist factors or solidarities have also been avoided by the Indonesian government when expressing Indonesia's foreign policy, including issues that have become Muslim concerns. However, as a political and social force, the salient role of Islam cannot be disregarded, especially in the post-Suharto era. Indonesian Muslim groups' aspirations have been apparent in the country's foreign policy. The author argues that the Indonesian government usually uses humanitarian terms as its reasoning when addressing issues relating to Muslims in Bosnia, Muslims in Kosovo, and the Palestinian people. In regards to Palestinian statehood, the government also uses anti-colonialism as an ideological basis for its policy. We will look in more detail at this reasoning below.

Third, the influence of Islam may come in the form of Muslim groups' pressures regarding international issues. The government of Indonesia usually responds to such pressures with reactive rather than active policies, as Muslim groups' pressures are also frequently reactive responses to international issues. These pressures created a reactive rather than active theme in Indonesian foreign policy, particularly during the Suharto era. In subsequent administrations, the Indonesian government's responses towards Muslim groups' aspirations have led to both reactive and active forms of foreign policy. We can find examples of a reactive foreign policy in the Indonesian government's response to Muslim aspirations in the case of the Gulf War and the US military operations in Afghanistan and Iraq. Meanwhile, active foreign policy has been found since the era of 
Megawati, and has intensified in the administration of Yudhoyono, in response to terrorism and misperceptions of Islam in the case of the Danish cartoon in 2007.

Fourth, although the role of Islam has generally become more important in the postSuharto period, especially in Yudhoyono's foreign policy, the extent of Islam's influence on Indonesian Foreign Policy has been demonstrated in more detail in the case studies of Chapters 4 to 6 . The discussion on the three case studies has confirmed the applicability of the first and the second hypothesis which are presented earlier in this chapter.

\section{Main features of the three case studies}

\subsection{The Iranian nuclear programme (Chapter Four)}

This case showed that the Indonesian government remained the key player in foreign policy making in its control of both policy process and implementation. However, the domain of the government on technical aspects of diplomacy in the UNSC was influenced by non-state actors, mainly Muslim groups and the parliament. The government was previously independent when deciding on issues in multilateral fora. The democratisation has allowed foreign policy stakeholders including Muslim groups to be more included in foreign policy making. Muslim groups' involvement has been mainly related to Indonesia's public diplomacy. This began when the government needed their involvement to minimise international misperceptions of the Muslim world, including Indonesia, following the events of 9/11. Muslim groups' involvement became more intense when the Indonesian government needed their presence in Indonesia's public diplomacy in the aftermath of the Bali bombings to help recover the country's image.

The Iranian nuclear issue posed a major dilemma for the Indonesian government. First, it did not want its privilege as an independent player in multilateral fora to be diluted by Muslim groups and the parliament. Second, the government had to entertain domestic aspirations while at the same time considering other countries' interests in the issue. In other words, the Indonesian government had to strike a balance between domestic and international factors to produce the best policy option. Major pressures from Muslim groups and members of parliament on a foreign policy occurred for the first time. This was

a reactive response from Muslim groups and parliament but it greatly shocked the Indonesian government. 


\subsection{The recognition of Kosovo's independence (Chapter Five)}

Indonesia was involved in the Kosovo issue after being elected as a non-permanent member of the UNSC in the period of 2007-2008. During that time, the Kosovo crisis became a pressing issue in the UNSC. Since the beginning, Indonesia faced the dilemma of whether or not to recognise Kosovo's independence. This situation had made Indonesia take a very cautious stance during the talks on the final status of Kosovo in 2007. Indonesia's statement in response to Kosovo's unilateral declaration of independence in February 2008 reflected its mid-way or indecisive position. Without ruling out recognition in the future, Indonesia was concerned about the implications of independence and did endorse Kosovo's statehood.

Muslim groups' aspirations for the government of Indonesia to recognise Kosovo's independence have remained unmet. Some Muslim groups, and especially Muhammadiyah, have persistently put pressure on the Indonesian government. However, the Indonesian government seems unlikely to recognise Kosovo until Serbia, the parent state, has agreed. The government of Indonesia has remained cautious in this matter, and regards the issue as sensitive. It considers that any miscalculation will bring Indonesia's national integrity into danger, with repercussions for Indonesia's territory.

It is interesting to note that despite the low level of their pressure, some Muslim groups, especially Muhammadiyah, have persistently voiced their aspirations urging the Indonesian government to recognise Kosovo's independence. Muhammadiyah has used various ways to put pressure on the Indonesian government to recognise Kosovo's independence.

\subsection{Palestinian statehood case (Chapter Six)}

This case demonstrates the policies of different Indonesian administrations towards Palestinian statehood. The country's basic position has remained the same, however the subtle shift of policies toward Palestinian statehood appeared in the era of Suharto. The long road toward opening a PLO mission in Indonesia shows this subtle shift. The proposal to open the mission emerged in 1972, but Suharto's regime did not permit it until 1989. 
The coming of the democratic era has marked the emergence of freer articulations of opinion and interest by both moderate and militant Indonesian Muslim groups, and both have had more opportunities to express their aspirations towards Palestinian statehood. In the democratic era, Muslim groups have been able to channel their concerns regarding Palestinian statehood not only through Muslim organisations such as NU and Muhammadiyah, but also through Islamic political parties. Street rallies, social media and printed mass media have also been utilised by Muslim groups to express their concerns on Palestinian statehood.

Yudhoyono identified support for Palestinian statehood as one of his main concerns. He showed his commitment on this issue in a variety of ways, ranging from verbal to material support. The Indonesian government supported the operation of the Palestinian Embassy in Jakarta and actively sought international support for Palestinian statehood at various regional and multilateral fora. The Indonesian government under President Yudhoyono responded to the aspirations of Muslim groups favourably. Dr Yayan Ganda Mulyana from the office of Presidential Staff on Foreign Relations states that the Yudhoyono administration welcomed and took into account Muslim groups' aspirations in the area of foreign policy including on Palestinian statehood. The president used these aspirations in a pragmatic way, guided by the principles of an independent and active foreign policy (interview with Yayan G. Mulyana, 18/01/2014).

\section{Case study comparison}

The interplay between Indonesian Muslim groups and the government of Indonesia reflects the pattern of state-society relationships in a democratic country and within an international context as suggested by the combination of Skidmore and Hudson's statistpluralist (societal) approach and Putnam's approach. In a democratic state, the government is concerned about maintaining support from domestic political constituents. The government has an interest in retaining its power and extending greater influence and effectiveness on the issues that it needs to address.

This important sub-section of the Conclusion will also touch on the factors that have determined the Indonesian government's accommodation of the aspirations of Muslim groups. One such factor is the sheer magnitude of the pressure from these groups on the government. This magnitude is shaped by perceptions among these groups on whether the 
issues are related to Muslim belief system, whether gross human right violations are seen to be occurring against Muslims, the geographical distance from Indonesia, and historical, social, educational, and religious ties with Indonesian Muslim groups.

Among the three cases, the author argues that Kosovo's independence is the least sensitive. However, the Kosovo issue was still sensitive for the Indonesian government as it believed it would possibly lead to repercussions for Indonesia's national integrity. Had Indonesia recognised Kosovo's independence, advocates of separatist groups in Indonesia could possibly have caused a backlash against the Indonesian government on this issue.

Palestinian statehood, the most sensitive of the three cases, has traditionally been regarded in Indonesia along the lines of Bosnian Muslim or Muslim Rohingya issues. These issues are full of perceived injustices, human rights violations and crimes against humanity. There is a high emotional attachment on the part of Indonesian Muslims to the Middle East. Religious and educational relations with the Middle East have existed since the arrival of Islam in Indonesia. Many Middle-Eastern peoples, including the Palestinians, have supported Indonesia since the beginning of its struggle for independence.

As most Indonesian Muslims still consider that Palestinian issues are also heavily related to religious sentiment, this issue has become increasingly sensitive. Palestinian issues have been frequently exploited for domestic political purposes including the consolidation of a party like PKS whose constituents have significant concerns about Palestinian issues. Likewise, militant Muslim groups in Indonesia through various means have used the Palestinian issue to consolidate their followers and sympathisers. Palestinian issues have frequently come under the spotlight in Indonesia. The Indonesian public has been bombarded with Palestinian news. Anything that occurs in Palestine is of high concern to Indonesian Muslim groups. In such a situation, any incidents or events related to the Palestinian people have sparked massive pressures among Muslim groups and parliament despite their alignment of aspirations with the government's policy towards Palestine.

In comparison to the Palestinian case, Iran's nuclear programme revealed a different phenomenon. Normally such an issue would not have been a sensitive one for Indonesian Muslim groups, yet the involvement of the US and the connection to Israel's nuclear programme made a difference here. Muslim groups viewed that unfair treatment had been imposed on a Muslim country like Iran, and argued that similar treatment had not been 
applied to Israel. Muslim groups were not happy with the Indonesian government's explanation that Israel was not (and is still not) a member of the NPT, so it would not be treated as such. Muslim groups perceived that injustices and Western double standards had been imposed on Iran.

There are three additional factors which can explain why the Iranian nuclear case became a sensitive issue and received strong reactions from Muslim groups. First, Muslim groups were still deeply traumatised by US-led military actions in Afghanistan and Iraq. The Indonesian government's support for UNSC resolution 1747 on sanctions against Iran was regarded as support for possible attacks by the US and its allies on Iran. The US had called Iran one of the three states of the axis of evil. In this regard, ElBaradei (2011) states that "at that time there was considerable disagreement within the US government: the hawks seemed to be advocating a military strike and regime change in Tehran, despite the lessons of the Iraq" (p. 131). Partly due to the fear of a US attack on Iran, Muslim groups expected that the Indonesian government would support Iran which had received unfair treatment at the hands of the US and its allies.

Second, this issue did not stand alone. It involved the US and Israel. Muslim groups in Indonesia have had long held negative attitudes towards the US and Israel. Thus, it is understandable why the Iranian nuclear issue greatly ignited Muslim groups, leading them to pressure the Indonesian government. Third, Muslim groups did not seem to be worried about the prospect of Sunni-Shiite conflict which has flared up in more recent years as a result of the Syrian civil war. At that time Iran was still 'unanimously' regarded by Muslim groups as a Muslim country which had been treated unfairly by Western countries in relation to nuclear issues.

Because of the above factors, Muslim groups regarded the Iranian nuclear issue as sensitive and put significant pressure on the Indonesian government after it supported UNSC resolution 1747. The Indonesian government seemed to regard this issue as a normal technical process of diplomacy. That was not the perception of Muslim groups.

As the recognition of Kosovo's independence is relatively less sensitive, this issue has not attracted nation-wide Muslim reaction in Indonesia. In general, Muslim groups have not been familiar with this issue. Only some Muslim groups, in particular Muhammadiyah, have consistently put pressure on the Indonesian government with regard to Kosovo's 
independence. When the Kosovo crisis came to the surface and into the international spotlight in the early 1990s, Muslim groups' attentions were overshadowed by the Bosnian crisis, which had sparked major protests among Indonesian Muslim groups.

There are some factors that could explain why this issue has not spread widely among Indonesian Muslim groups and has not become a sensitive issue. First, the geographical distance greatly determines the level of awareness of Indonesian Muslims on the Kosovo crisis and the independence of Kosovo. Fewer Indonesian Muslims are aware that there is a Muslim majority country like Kosovo in Europe. Second, Western countries have become the main sponsor of Kosovo's independence. Third, the peak of the Kosovo crisis in the 1990s was concurrent with the situation in which Indonesia had to struggle with its own pressing problems in the aftermath of a financial and economic crisis as well as the East Timor situation.

The level of sensitivity has greatly determined the magnitude of Muslim groups' pressure on the Indonesian government. However, aside from domestic factors international pressures and the government's interests in international forums have also played a role. These external factors were most apparent in the Iranian nuclear programme, but less apparent in the recognition of Kosovo's independence and the Palestinian statehood. Putnam's two-level game approach clearly captures how the government has tried to strike a balance to maintain international bargaining power and satisfy domestic aspirations from Muslim groups and the parliament.

When deciding to support UNSC resolution 1747, it is as if the Indonesian government thought it has had full autonomy from societal constraints on foreign policy issues, particularly on issues negotiated in multilateral forum such as the UNSC. At that time, the government overruled the possibility of being pressurised by society, especially Muslim groups. They traditionally did not pay much domestic attention in this regard to issues which were negotiated in the UN. Here Indonesia's foreign policy behaviour reflected Skidmore and Hudson's statist approach which also closely resembles Realist theory. According to this statist theory, the government assumes that it formulate foreign policy autonomously from the influence and participation of society (Skidmore \& Hudson, 1993, p. 7). 
In this vein, the national interest of a state is determined by the state's position in the international system. Constraints and opportunities which are presented by the international system will determine the national interests of a state. The strong assumption of this theory is that interests and values of society correspond with those of the state (Skidmore \& Hudson, 1993). But it seems odd to assume that the government of Indonesia was not aware that its foreign policy on Iran was being scrutinised by society given that the democratic era had been entered since 1998. Likewise it is unwise to embrace the assumption of the Statist approach which holds that the government of Indonesia has had full autonomy in formulating foreign policy.

The Indonesian government's support for sanctions against Iran was likely driven by strong international pressure, especially from the US. This was strengthened by a particular view of the government of Indonesia on the necessity of creating a peaceful world by preventing any efforts to develop nuclear weapons. Muslim groups were highly suspicious that the Indonesian government's decision to support UNSC resolution 1747 was due to pressure from the US and its allies. The Indonesian government's rejection of these claims did not change Muslim groups' suspicions. Their suspicion that the Indonesian government was under international pressure may have been justified given Bush's phone call to Yudhoyono before the vote on 1747.

In the aftermath of strong pressures from Muslim groups and the parliament, the government of Indonesia seems to have simultaneously negotiations at both the national and international levels allowing the government to absorb the aspirations of Muslim groups and the parliament and at the same time negotiate on the basis of its international interests at the UNSC. According to Putnam's approach, the government should seek an outcome that is most likely to be accepted by domestic constituents and that should also not harm Indonesia's international interests. Accordingly, the government decided that abstaining on resolution 1803 was its best policy option. It seems that the government shifted from behaviour reflecting the statist approach to behaviour in line with the pluralist approach of Skidmore and Hudson, who argue that governments "care most about maintaining high level of domestic political support" (Skidmore \& Hudson, 1993, p. 9). It is worth mentioning that Indonesia was the only member of the UNSC that abstained on this resolution in light of its consideration of domestic pressure from Muslim groups and parliament. 
On the Kosovo and Palestinian cases, on which Indonesia has taken a different position from the US, there is no evidence for the existence of American pressure on Indonesia. The author argues that even if this pressure did exist, it would not be sufficient to alter Indonesia's policy on Kosovo and Palestine. In these two cases, Putnam's approach does not apply. It seems that the Indonesian government did not need to strike a balance between domestic aspirations and international interests to achieve its best policy option. In these two cases, the author finds that it is only the state-societal relationships approach as suggested by Skidmore and Hudson (and not Putnam's approach) which applies in any significant way.

The pluralist approach may be most appropriate in capturing the detailed interplay between the government and society in a relative weak political system and competitive political process (Skidmore \& Hudson, 1993, p. 10) as occurs in Indonesia. Putnam's approach fails to capture the detailed dynamic of society-state relationships as his approach does not identify domestic factors as the central variable. Putnam's approach is more applicable when Indonesia has been involved directly in international negotiations on an issue, as seen in Indonesia's approach to the Iranian nuclear programme at the UNSC for the period of 2007-2008. In the cases of Kosovo and Palestine, Indonesia has for the most part not been directly involved in the negotiations, and thus Putnam's approach may be less relevant.

Like Coplin (1971), Skidmore and Hudson's statist-pluralist approach also allows for the role of domestic constituents who have concerns about foreign policy decision making. Subsequently, this approach also offers useful background to the differences among authoritarian and democratic systems, whereas Putnam's approach does not specifically discuss this issue. However, if the statist-pluralist approach is the only approach used to analyse all the three cases of the thesis, it is not enough to capture the nuances of the interplay between Muslim groups and the government on the Iranian nuclear programme and Indonesia's foreign policy in the post-Suharto era in general, especially for issues related to terrorism, Afghanistan, and Iraq.

Combining Putnam's approach and Skidmore and Hudson's statist-pluralist approach, and in particular using the latter, offers a better framework for analysing the interplay between the Indonesian government and Indonesian Muslim groups. This combination has managed 
to capture the complex relationship between Muslim groups and the Indonesian government in both domestic and international contexts. However, neither approach explains when and how interest groups such as Muslim groups can effectively exert their influence on a foreign policy decision making process.

\subsection{Muslim groups' aspirations and the government's accommodation}

In general, Muslim groups' aspirations and pressures influence Indonesia's contemporary foreign policy as long as the issue is not seen by the government to threaten the country's most vital interest of national territorial integrity. This factor aside, the greater the pressure from Muslim groups, the greater influence will they will have on the government. This pressure in turn depends on the domestic sensitivity of the issue. As mentioned earlier the Iranian nuclear programme and the Palestinian question have been regarded as more sensitive issues in Indonesia. Thus, it is understood that Muslim groups' put particular pressure on the government of Indonesia in relation to those two cases. But which of these will result in a bigger influence and which will result in a less effective influence attempt?

In relation to these questions, this thesis firstly confirmed that Muslim groups' aspirations have more influence and are more likely to be accommodated by the Indonesian government when these groups' aspirations converge with the interests and aspirations of other foreign policy stakeholders. The three case studies have presented different pictures regarding this point. The case of the Iranian nuclear program has demonstrated that the role of Muslim groups became stronger when their aspirations converged with the interests of broader political constituents, mainly the Indonesian parliament. Meanwhile, the Palestinian statehood case showed that the views of Muslim groups have not only converged with other broader constituencies but have also aligned with government policy. The Indonesian government and Muslim groups have been united in perspective on the Palestinian issue in the democratic era. In the case of Kosovo's independence, Muslim groups and members of parliament were found to have had divided views. Second, this thesis also confirmed that Muslim groups' aspirations are less effective and will not likely be accommodated by the government if their aspirations are contradictory with the most vital strategic interests in relation to national territorial integrity. This also became clear in the case of Kosovo's independence. 
Subsequently, the convergence of Muslim groups' aspirations with broader national constituencies and the conformity of Muslim groups' aspirations with the most national strategic interest in relation to national territorial integrity will determine the level of the government's accommodation. Before, looking at detail into these two points, it is worth mentioning that measuring the influence of Muslim groups on the foreign policy process does not reflect a zero sum game. According to a zero sum model, the role of Muslim groups might only be regarded as important if they can replace the position of the government in the conduct of foreign policy. If not, their role is not important. This thesis does not adopt such an approach because the government's position on the conduct of foreign policy cannot be supplanted. The government always remains Indonesia's main foreign policy actor. Instead, this thesis considers that the role of Muslim groups can be regarded as substantial if their pressures or aspirations can influence or change the attitude, position, and decision of the Indonesian government on foreign policy so as to reflect or favour their concerns and aspirations.

The case of Iran's nuclear program has demonstrated that pressure from Muslim groups were effective in influencing the Indonesian government's foreign policy formulation. This was indicated by the shift of the Indonesian government's position from supporting UNSC resolution 1747 on sanctions against Iran to abstaining on the similar resolution 1803. The change of the Indonesian government's position was believed by many to be the result of the pressures of Muslim groups and many members of the Indonesian parliament. The accommodation of Muslim groups' aspirations became more possible when these aspirations corresponded with the interests of politicians in parliament. At that time, following the harsh reactions of NU and Muhammadiyah to the government's decision, parliament promoted these aspirations. Similarly, members of parliament from political parties that constituted Yudhoyono's political coalition such as PAN, PKB, PKS, and Golkar also responded negatively to the government's decision in relation to Iran's nuclear program. PKB and PAN-whose voters are mainly followers of NU and Muhammadiyah respectively - apparently did not want to lose their constituents. Likewise, both NU and Muhammadiyah have good connections with members of parliament in order to channel their aspirations to other political parties beyond PKB and PAN. NU and Muhammadiyah have cadres in various political parties, including nationalist parties such as Golkar and PDIP. As a result, Muslim groups and the parliament had considerable bargaining power to oppose the government's decision on supporting sanctions on Iran. The shift in the 
government's position might also have been driven by the Yudhoyono administration's interest in retaining its power and surviving parliament's adopting of its right of interpellation. Yudhoyono also did not want to lose Muslim groups' support so as to retain power until the end of his first period of presidency and to succeed in the 2009 election, the result of which would clearly be determined by Muslim voters who make up the majority of electors.

However, the government has denied that its changed position on this issue was due to public pressure. The government's denial has been widely questioned, including by Indonesian intellectuals. Whatever the reason, despite much domestic opposition to the government's abstention, that decision to abstain has been generally welcomed by Muslim groups and members of parliament. Many believe that the abstention position on resolution 1803 was the best choice as the government needed to consider both domestic and international factors. By abstaining, Indonesia's position was viewed by many members of DPR as independent. It meant that Indonesia had not followed the US and its allies in the UNSC. This abstention brought about US disappointment. In this vein, KH Hasyim Muzadi claims that "Foreign Minister Hassan Wirajuda told me that the US was disappointed with the position of Indonesia on resolution 1803" (interview with Hasyim Muzadi, 29/12/2013).

The extent to which Muslim groups have influenced the Indonesian government's policy on Palestinian statehood can be regarded as very substantial. Indonesia's policy on Palestine has been consistent in supporting the struggle of the Palestinians against Israel. The country's non-recognition policy towards Israel and the absence of formal relations at any level with Tel Aviv has reflected an interpretation of the mandate in the 1945 Constitution which holds that all forms of colonialism should be abolished. The absence of formal relations with Israel has also reflected the Indonesian government's accommodation of Muslim groups' aspirations. Any Indonesian government policy that has appeared to rule out Muslim groups' concerns on Palestine has met with failure. This situation was experienced by Wahid, whose willingness to establish official trade relations with Israel failed after gaining a harsh reaction from Muslim groups. As the Indonesian public sphere has become more Islamized in the post-Suharto period, Indonesia's support for the Palestinian struggle to have an independent state has become more apparent. Yudhoyono endeavoured to bring Indonesia's foreign policy on Palestine to a level which 
was not only reactive in nature but also an example of activism in foreign policy. Suharto's latter foreign policy could be seen as reactive towards both Palestine and the Middle East in general. Yudhoyono affirmed that his foreign policy on Palestine was not just rhetorical but involved a concerted effort to support Palestine.

The Palestinian case has also indicated the same phenomenon as found in the case of the Iranian nuclear programme where the government had an interest in getting support from society and parliament to retain its power. Indonesia's consistent position on Palestinian statehood was not only rationalised by the constitutional argument but also by the 'united voice' of various elements, especially Muslim groups in supporting the Palestinian people. Although the Indonesian government's foreign policy on Palestine was already aligned with Muslim group' aspirations, these groups have still put pressure on the government in case it was seen as too slow or uncommitted in supporting the efforts of the Palestinian people.

Despite some differences in attitudes between moderate and militant Muslim groups in Indonesia, their general views on this issue are uniform. Muslim groups believe that the Palestinians have long lived under the suppression of a colonialist Israel which has ignored their rights. The Palestinians are seen to have suffered persistent injustices due to Israel and its Western supporters. There is widespread opinion among Muslim groups that Palestinian statehood has gained little support among international society, which is represented by the UNSC. Muslim groups believe that there has not been enough effort made by UN members to force Israel to comply with UNSC resolutions on Palestine. There is a general view among Muslim groups that the US as a champion of human rights has set a double standard in relation to Israel and Palestine. These views among Indonesian Muslim groups are generally shared by the Indonesian government and the parliament.

Another factor explaining the Indonesian government's accommodation of Muslim aspirations on both the Iranian nuclear programme and Palestinian statehood is that these particular aspirations do not conflict with strategic national interests. The shift of the government's position from initially supporting sanctions on Iran to a position of abstention on resolution 1803 was likely to happen because such a change did not threaten Indonesia's strategic national interests, such as territorial integrity. Moreover, Indonesia's support for a Muslim country did not damage Indonesia's relations with the US as the 
main advocate of sanctions on Iran. The US has had strong allies among Muslim countries including Saudi Arabia and Egypt.

In the Kosovo case, the government appears to have firmed up its non-recognition of Kosovo's independence and has disregarded the aspirations of some Muslim groups. Unlike in the Iranian and Palestinian cases, in the Kosovo case, the government has not appeared to seek support from Muslim groups to retain its power as it has been convinced that a firm position is needed to maintain national territorial integrity. The government also has likely seen that Muslim groups and the parliament in Indonesia are divided in voicing support for Kosovo's independence. Only Muhammadiyah and some members of parliament have consistently voiced the necessity for Indonesia to recognise Kosovo. Admittedly, only leaders and elites of Muslim groups have been cognizant of and familiar with the Kosovo issue, not their members or followers at the grassroots level. Consequently, no major protests or demonstrations from Muslim groups combined with strong political pressures from members of parliament have occurred. The absence of Muslim groups' political aspirations and the lack of political interest of parliamentarians has weakened pressure on this issue in contrast to the Iranian nuclear program. As such, the government calculated that the pressures that emerged from Muslim groups and parliament were low and would not endanger their power.

The government's non-accommodative policy on the recognition of Kosovo's independence is driven by the government's view that Muslim groups' aspirations would threaten Indonesia's strategic national interest. Their aspirations confront the most profound national interest of the Indonesian government. The government regards territorial integrity as fundamental and non-negotiable.

In short, the increasing role of Muslim groups in Indonesia's contemporary has become more possible with the coming of democratisation in the country. And this increased influence of Muslim groups occurs in particular on international issues of importance to them. The increased influence of Muslim groups has been reflected in the increasing accommodation of their concerns and Islamic elements in the government's foreign policy. The three case show in detail that the government's accommodations have been determined by the magnitude of Muslim groups' pressures which depend on the level of sensitivity of issues; the level of convergence of Muslim groups' aspirations with the 
interests of broader foreign policy stakeholders; and the conformity of Muslim groups' aspirations with the most vital national strategic interests.

Neither Putnam's approach nor Skidmore and Hudson's statist-pluralist (societal) approach specifically provide an account of when and how societal factors reflected in particular interest groups influence government policy. Hence, this thesis breaks important ground by showing that the interest groups, in this case Indonesian Muslim groups, increase their influence when there is a convergence of their aspirations with the interests of broader foreign policy stakeholders. On the other hand, Muslim groups' will lack influence when their aspirations threaten the most vital strategic interest and when they are fundamentally contrary to Pancasila, Indonesia's 1945 Constitution and the independent and active foreign policy principles. The thesis has found that the interplay between Muslim groups and the Indonesian government has led to 'reactive accommodation' in the Iranian nuclear case and 'foreign policy activism' in the case of Palestine, but little of either in the case of Kosovo's independence.

\section{Reflection on thesis contribution and future research}

This thesis suggests that there has been an increased role of Islam in Indonesia's foreign policy in the post-Suharto era, a conclusion which differs from the approach taken in previous studies. This thesis contributes to the notion that the Indonesian 'secular' statedespite its Pancasila status - has allowed 'more negotiation and dialogue' with religious elements in the post-Suharto era. The inclusion of Islamic elements in Indonesian politics, including in foreign policy, has become more apparent. One element of the post-Suharto 'secular' state is the implementation of shariah law in certain regions in Indonesia. This phenomenon has involved intense negotiation and dialogue between 'secular practices' and religious elements and is really only a feature of the democratic post-Suharto era.

From this perspective it becomes clear that the increased role of Islam in Indonesian foreign policy was possible in an era which allowed a greater Islamic content in the public sphere. This conclusion differs from previous studies which have focused on the predemocratic era where negotiations between Islamic elements and the secular nature of Indonesian statehood did not occur. Especially when these studies have emphasised the secular nature of Indonesian statehood, they find it easy to conclude that Islam occupies a 
marginal position. When this logic is applied, Islam is generally not considered as an asset in the way Yudhoyono came to see it, but remains a liability for Indonesia's foreign policy.

In suggesting on the other hand that Islam now enjoys an increased role in Indonesia's foreign policy, this thesis points the way for future research which might explore the increased influence of transnational Muslim groups in Indonesian foreign policy. For example, could the role of mainstream Islam, which is represented by moderate Muslim groups such as NU and Muhammadiyah, be severely undermined by militant Muslim groups with transnational links to the Middle East? Alternatively if moderate Muslims maintain a dominant influence in Indonesia's social-religious life, future research could instead focus on the role of an evolving NU or Muhammadiyah in the making of Indonesia's foreign policy. Either way, there are rich opportunities for additional research built on the findings of this thesis. 


\section{REFERENCES}

Abazi, E. (2008). Kosovo independence: An Albanian perspective. SETA Policy Brief, April(11), 1-5.

Abdullah, T. (2009). Indonesia towards democracy. Singapore: Institute of Southeast Asian Studies (ISEAS).

Adamrah, M. (2010, 27 July). ICJ ruling 'could inspire RI separatists' The Jakarta Post Retrieved from http://www.thejakartapost.com/news/2010/07/27/icj-ruling-couldinspire-ri-separatists039.html

Aghsan, A. R. (2011). Turkey's EU quest and political cleavages under AKP. Review of European Studies, 3(1).

Agung, I. A. A. G. (1973). Twenty years Indonesian foreign policy: 1945-1965. The Hague: Mouton.

Ahmad, S. (2014, 16 April ). Indonesian political Islam fails again The Jakarta Post. Retrieved from http://www.thejakartapost.com/news/2014/04/16/indonesianpolitical-islam-fails-again.html

Akbar, C. (2013, 28/05). Ketua Umum PP Muhammadiyah bertemu Presiden Kosovo (The general chairman of Central Executive Board of the Muhammadiyah met President of Kosovo). Hidayatullah.com. Retrieved from http://www.hidayatullah.com/berita/internasional/read/2013/05/28/3363/ketuaumum-pp-muhammadiyah-bertemu-presiden-kosovo.html

Akhmad, C. (2014, 22 November ). Din dorong Jokowi akui negara Kosovo (Din urges Jokowi to recognize Kosovo). Republika Online. Retrieved from http://www.republika.co.id/berita/nasional/umum/14/11/22/nffz83-din-dorongjokowi-akui-negara-kosovo

Al-Hakim, S. (2013). Perkembangan regulasi perbankan syariah di Indonesia (The development of regulations on syariah banking in Indonesia). Wacana Hukum Islam dan Kemanusiaan, 13(1), 15-32.

Al-Hamdi, R. (2013). Partai politik Islam: Teori praktik di Indonesia (Islamic political parties: Theory and practice in Indonesia). Yogyakarta: Graha Ilmu.

Al-Hamid, N., \& Naffee, I. (2012, 18 June ). Kosovo to set join OIC. Arab News Retrieved from http://www.arabnews.com/kosovo-set-join-oic

Al-Intima. (2013, 17 May). Umat dorong pemerintah RI akui kemerdekaan Kosovo (Umat urges the Indonesian government to recognize Kosovo). Retrieved from http://www.al-intima.com/berita-ummat/umat-dorong-pemerintah-ri-akuikemerdekaan-kosovo

Al-Irsyad. (2012, 25 May). Pemuda Al-Irsyad minta pemerintah RI dukung kemerdekaan Kosovo ( Al-Irsyad Youth requests the government of RI to support Kosovo's independence)

Pengurus Besar Pemuda Al Irsyad (Central Board of Al-Irsyad Youth). Retrieved from http://www.pemudaalirsyad.or.id/2012-05-25-22-41-10/internasional/22-pemudaal-irsyad-minta-pemerintah-ri-dukung-kemerdekaan-kosovo.html

Alami, A. N. (2011). Profil dan orientasi kebijakan luar negeri Indonesia pasca orde baru (Profile and orientation of Indonesia's foreign policy in the post new order). Jurnal Penelitian Politik, 8(2), 163-181. 
Albeu. (2011, 14 September). Arab countries may recognize the independence of Kosovo. Albeau.com. Retrieved from http://english.albeu.com/news/news/arab-countriesmay-recognize-the-independence-of-kosovo/45899/

Alexandra, L. A., \& Basuki, T. (2014). Democracy, human rights and Indonesia's foreign policy under Yudhoyono. The Indonesian Quarterly, 42(3-4), 183-200.

Ali, M. (2013). Islam in modern Southeast Asian history. In N. G. Owen (Ed.), Routledge hanbook of Southeast Asian history. London: Routledge.

Almqvist, J. (2009). The politics of recognition, Kosovo and international law. Documento de Trabajo: Working Paper, 14/2009, 1-16.

Aminah, A. N., \& Festiani, S. (2013, 17 January). Kosovo: We need Indonesia to recognize our independence. Republika Online. Retrieved from http://www.republika.co.id/berita/en/islam-in-archipelago/13/01/17/mgs17nkosovo-we-need-indonesia-to-recognize-our-independence

Amri, A. B., \& Dewi, S. (2013, 16 May). Mengapa RI belum akui Kosovo negara, 99 negara sudah (Why does not recognize Kosovo yet, 99 did). Viva.co.id. Retrieved from http://dunia.news.viva.co.id/news/read/413473-mengapa-ri-belum-akuikosovo-negara--99-negara-sudah

Amrullah, A. (2013, 23 October). Serbia minta Indonesia tak akui Kosovo (Serbia asks Indonesia not to recognize Kosovo). Republika Online. Retrieved from http://www.republika.co.id/berita/nasional/umum/13/10/23/mv4586-serbia-mintaindonesia-tak-akui-kosovo

An Na'im, A. A. (2008). Islam and the secular state: Negotiating the future of shari'a. Cambridge, Massachusetts: Harvard University Press.

Ananta, A., Arifin, E. N., \& Suyadinata, L. (2005). Ermerging democracy in Indonesia. Singapore: ISEAS.

Anderson, G. (1998). Fundamentals of educational research (Second ed.). London: Routledge-Falmer.

Ansari, A. M. (2007). Iran under Ahmadinejad: The politics of confrontation. London: Routledge.

Anshari, A. M. (2006). Civilizational identity and foreign policy: The case of Iran. In B. Shaffer (Ed.), The limits of culture: Islam and foreign policy. Cambridge, Masschusetts: The MIT Press

Antara. (1999a, 2 November). Indonesia-Israel trade ties plan meets with protest. AntaraNews.com. Retrieved from http://go.galegroup.com/ps/i.do?id=GALE\%7CA57091473\&v=2.1\&u=vuw\&it=r\& p=ITOF\&sw=w\&asid=22ecb986c4e2ffcadbd8a1f02d733859

Antara. (1999b, 12 November). Indonesia's House won't allow trade relations with Israel. AntaraNews.com. Retrieved from http://go.galegroup.com/ps/i.do?id=GALE\%7CA57530915\&v=2.1\&u=vuw\&it=r\& $\mathrm{p}=\mathrm{ITOF} \& \mathrm{sw}=\mathrm{w} \& \mathrm{asid}=\mathrm{c} 27 \mathrm{a} 52440 \mathrm{~d} 066 \mathrm{ec} 959 \mathrm{c} 5406 \mathrm{edba75069}$

Antara. (2007a, 27 March). PPP demo konjen AS prrotes resolusi nuklir Iran (PPP rallies in front of US Consulate General prostesting Iran's nuclear). AntaraNews.com. Retrieved from http://www.antaranews.com/berita/57208/ppp-demo-konjen-asprotes-resolusi-nuklir-iran

Antara. (2007b, 3 April ). Demo cabut dukungan resolusi DK PBB dekat istana Bogor (Demonstration near Bogoe palace to revoke support on UN resolution). AntaraNews.com. Retrieved from http://www.antaranews.com/berita/57826/democabut-dukungan-resolusi-dk-pbb-dekat-istana-bogor

Antara. (2010, 23 September). Indonesia, three other nations to set up forum to support Palestine independence. AntaraNews.com. Retrieved from 
http://search.proquest.com/docview/752129333?pq-

origsite $=$ summon $\&$ accountid $=14782$

Antara. (2011a, 20 September ). RI to continue supporting Palestine`s UN membership bid. AntaraNews.com from http://www.antaranews.com/en/news/75844/ri-to-continue-supporting-palestinesun-membership-bid

Antara. (2011b, 20 September). Indonesian, Palestinian FM meet over bid for UN membership. AntaraNews.com. Retrieved from http://www.antaranews.com/en/news/75864/indonesian-palestinian-fm-meet-overbid-for-un-membership

Antara. (2012a, 5 July). DPR: Indonesia to open consulate in Ramallah. AntaraNews.com. Retrieved from http://search.proquest.com/docview/1023433847?pqorigsite $=$ summon $\&$ accountid $=14782$

Antara. (2012b, 2 October). Indonesia to prepare road map for international protocol on blasphemy. AntaraNews.com. Retrieved from http://www.antaranews.com/en/news/84838/indonesia-to-prepare-road-map-forinternational-protocol-on-blasphemy

Anwar, D. F. (1994). Indonesia's foreign policy after the Cold War. Southeast Asian Affairs, 146-163.

Anwar, D. F. (2005). Indonesia at large: Collected writings on ASEAN, foreign policy, security and democratization. Jakarta: The Habibie Center.

Anwar, D. F. (2010a). Foreign policy, Islam and democracy in Indonesia. Journal of Indonesian Social Sciences and Humanities, 3, 37-54.

Anwar, D. F. (2010b). The impact of domestic and Asian regional changes on Indonesian foreign policy. Southeast Asian Affairs.

Arabbews, J. A. Z. (2013, 13 January). Kosovo wants all OIC states to recognize The Muslim Times Retrieved from http://www.themuslimtimes.org/2013/01/countries/saudi-arabia/kosovo-wants-alloic-states-to-recognize-it\#ixzz3JVCvj8rx

Aras, B. (2009). The Davutoglu era in Turkish foreign policy Insight Turkey 11(3), 127142.

Aras, B. (2014). Davutoğlu era in Turkish foreign policy revisited. Journal of Balkan and Near Eastern Studies, 16(4), 404-418. Retrieved from http://dx.doi.org/10.1080/19448953.2014.938451

Arifin, F. A. (2014, 31 July ). Jihad konstitusi ala Muhammadiyah (Constitutional jihad according to Muhammadiyah). Muslimdaily.net. Retrieved from https://www.academia.edu/5832354/Jihad_Konstitusi_ala_Muhammadiyah

Arifin, M., \& Nasution, B. (2015). The dynamics study of regulations on syariah banking Indonesia. International Journal of Humanities and Social Science, 5(3), 237-242.

Aritonang, M. S., \& Santosa, N. I. (2012, 4 February). Indonesia to open rep office in Palestine The Jakarta Post Retrieved from http://www.thejakartapost.com/news/2012/02/04/indonesia-open-rep-officepalestine.html

Aryani, G. (2013, 17 November). Presiden canangkan Gres! di Monas (President launched shariah economic movement at national monument). AntaraNews.com. Retrieved from http://www.antaranews.com/berita/405382/presiden-canangkan-gres-dimonas

Asia-PacificNews. (2008, 20 February). Indonesia divided over Kosovo independence. Asia Pacific News. Retrieved from 
http://news.monstersandcritics.com/news/article_1392052.php/Indonesia_divided_ over_Kosovo_independence

Aspinall, E., \& Mietzner, M. (2014). Indonesian politics in 2014: Democracy's close call. Bulletin of Indonesian Economic Studies, 50(3), 347-369. Retrieved from http://dx.doi.org/10.1080/00074918.2014.980375

Asriani. (2008, 12 December 2008). Undang-undang perbankan syariah. VivaNews. Retrieved from $\quad$ http://m.news.viva.co.id/news/read/4893undang_undang_perbankan_syariah

Associated-Press. (1999, 25 October). Arab ambassadors: Indonesia won't establish relations with Israel. The Associated Press. Retrieved from http://www.lexisnexis.com/hottopics/lnacademic/?verb=sr\&csi=7911

Azra, A. (2000). Renaisans Islam Asia Tenggara: Sejarah wacana dan kekuasaan (The renaisance of Islam in Southeast Asia: The history of discourse and power) (second ed.). Bandung: Remaja Rosdakarya.

Azra, A. (2004). Political Islam in post-Suharto. In V. Hooker \& A. Saikal (Eds.), Islamic perspectives on the new millennium (pp. 133-149). Singapore: ISEAS.

Azra, A. (2006). Indonesia, Islam, and democracy: Dynamics in a global context. Jakarta: Solstice.

Azra, A. (2013). Posisi RI terhadap kemerdekaan Kosovo: Dilema dan ambiguitas konvensional (RI's position on Kosovo's recognition: Dilemma and conventional ambiguity). Paper presented at the Seminar on Posisi Indonesia dalam masalah Kosovo (Indonesia's position on Kosovo), Indonesia's House of Representative Building, Jakarta.

b92. (2009, 24 May). Saudi Kosovo proposal fails at OIC. b.92.net. Retrieved from http://www.b92.net/eng/news/politics.php?yyyy=2009\&mm=05\&dd=24\&nav_id= $\underline{59349}$

b.92. (2008, 26 August). Indonesia in strong support over Kosovo. b.92.net. Retrieved from $\quad$ http://www.b92.net/eng/news/politicsarticle.php? yyyy $=2008 \& \mathrm{~mm}=08 \& \mathrm{dd}=26 \&$ nav $\_\mathrm{id}=52989$

b.92. (2013a, 19 March). Indonesia to continue to support Serbia on Kosovo issue. b.92.net. Retrieved from http://www.b92.net/eng/news/politics.php?yyyy=2013\&mm=03\&dd=19\&nav_id= $\underline{85248}$

b.92. (2013b, 5 June). President thanks Indonesia for supporting Serbia's integrity. b92.net. Retrieved from http://www.b92.net/eng/news/politics.php?yyyy=2013\&mm $=06 \& d d=05 \&$ nav_id= $\underline{86520}$

Bacevich, A. J., \& Prodromou, E. H. (2004). God is not neutral: Religion and US foreign policy after $9 / 11$. Orbis.

Bahgat, G. (2007). Proliferation of nuclear weapons in the Middle East. Florida, USA: University Press of Florida.

Bakan, A. B., \& Abu-Laban, Y. (2010). Israel/Palestine, South Africa and the 'one-state solution': The case for an apartheid analysis. Politikon, 37(2-3), 331-351. Retrieved from http://dx.doi.org/10.1080/02589346.2010.522342

Baktiari, B. (2007). Iran's conservative revival. Current History: A History of Contemporary World Affairs, 106(696), 195-199.

Bardos, G. N. (2008). The regional and international implications of Kosovo independence. Mediterranean Quarterly, 19(4), 54-67. Retrieved from http://mq.dukejournals.org/content/19/4/54.abstract 
Barton, G. (2002). Islam and politics in the new Indonesia In J. F. I. a. C. Rubenstein (Ed.), Islam in Asia: Changing political realities (pp. 1-90). New Brunswick (USA): Transaction Publisher.

Barton, G., \& Fealy, G. (Eds.). (1996). Nahdlatul Ulama, traditional Islam modernity in Indonesia. Clayton, Australia: Monash Asia Institute

Barton, G., \& Rubenstein, C. (2005). Indonesia and Israel: A relationship in waiting. Jewish Political Studies Review, 17(1-2 (Spring)), 1-8.

Barzashka, I., \& Oelrich, I. (2012). Iran and nuclear ambiguity. Cambridge Review of International Affairs, 25(1), 1-26. Retrieved from http://dx.doi.org/10.1080/09557571.2012.656457

Baswedan, A. R. (2004). Political Islam in Indonesia: Present and future trajectory. Asian Survey, 44(5), 669-690. Retrieved from http://www.jstor.org/stable/10.1525/as.2004.44.5.669

Baumgartner, J. C., Francia, P. L., \& Morris, J. S. (2008). A Clash of civilizations? The influence of religion on public opinion of U.S. foreign policy in the Middle East. Political Research Quarterly. Retrieved from http://prq.sagepub.com/content/early/2008/02/09/1065912907307288.abstract

BBC. (2005, 7 September). Indonesia denies receiving "note" from Israel on diplomatic ties. BBC Monitoring Asia Pacific. Retrieved from http://search.proquest.com.helicon.vuw.ac.nz/docview/460672398?pqorigsite $=$ summon\&accountid $=14782$

BBC. (2007, 2 April). Indonesian minister supports questioning president on UNSC resolution on Iran. BBC Monitoring Asia Pacific p. 1.

BBC. (2007a, 23 March ). Indonesia proposes amendments to UN Security Council resolution on Iran. BBC Monitoring Asia Pacific, p. 1. Retrieved from http://search.proquest.com/docview/460918753?OpenUrlRefId=info:xri/sid:primo \&accountid $=14782$

BBC. (2007b, 16 February). Indonesia calls for nuclear cooperation with Iran. BBC Monitoring Middle East p. 1. Retrieved from http://search.proquest.com/docview/458650567?OpenUrlRefId=info:xri/sid:primo \&accountid $=14782$

BBC. (2009, 08 Jan 2009). Indonesia: Sending jihadis to Gaza not an option - foreign minister. BBC Monitoring Asia Pacific Retrieved from http://search.proquest.com/docview/460614178?pqorigsite $=$ summon\&accountid $=14782$

BBC. (2015, 2 November). Turkey election: Ruling AKP regains majority. BBC News. Retrieved from http://www.bbc.com/news/world-europe-34694420

Bechev, D. (2012). Turkey in the Balkans: Taking a broader view. Insight Turkey, 14(1), 131-146.

Behrendt, S. (2007). The secret Israeli-Palestinian negotiations in Oslo: Their success and why the process ultimately failed. New York: Routledge.

Bélanger, P., \& Eagles, M. (2006). The geography of class and religion in Canadian elections revisited. Canadian Journal of Political Science/Revue canadienne de science politique, 39(03), 591-609. Retrieved from http://dx.doi.org/10.1017/S0008423906060227

Benda, H. J. (1958). Christian Snouck Hurgronje and the foundation of Dutch Islamic policy in Indonesia. The Journal of Modern History, 30(4), 338-347.

Benda, H. J. (1977). South-East Asian Islam in the twintieth century. In A. K. S. L. P.M. Holt, Bernard Lewis (Ed.), The Cambridge history of Islam. London: Cambridge University Press. 
Berg, B. L., \& Lune, H. (2012). Qualitative research methods for social sciences. New Jersey, USA: Pearson.

Berger, P. L. (1999). The desecularization of the world: Resurgent religion and world politics. Michigan: William B. Eerdmans Publishing Company

BeritaSore. (2008, 20 February). Legislator: No reason for Indonesia not to recognize Kosovo's independence. Berita Sore. Retrieved from http://beritasore.com/2008/02/20/legislator-no-reason-for-indonesia-not-torecognize-kosovos-independence/

Berrebi, C., \& Klor, E. F. (2006). On terrorism and electoral outcomes: Theory and evidence from the Israeli-Palestinian conflict. Journal of Conflict Resolution, 50(6), 899-925. Retrieved from http://jcr.sagepub.com/content/50/6/899.abstract

Bickerton, I. J., \& Klausner, C. L. (2010). A history of the Arab-Israeli conflict.

Bilgin, H. D. (2008). Foreign Policy Orientation of Turkey's Pro-Islamist Parties: A Comparative Study of the AKP and Refah. Turkish Studies, 9(3), 407-421. Retrieved from http://dx.doi.org/10.1080/14683840802267363

Biyanto. (2015, 15 March 2015). Jihad konstitusi ala Muhammadiyah (Constituional Jihad according to Muhammadiyah). Jawa Pos. Retrieved from http://www2.jawapos.com/baca/opinidetail/14472/Jihad-Konstitusi-alaMuhammadiyah

Blitt, R. C. (2010). Russia's orthodox foreign Policy: The growing influence of the Russian Orthodox Church in shaping Russia's policies abroad. Paper presented during a Conference on Religion in the Public Sphere at at Central European University, Budapest, Hungary on 4-5 June 2010.

Bloembergen, M. (2006). Colonial spectacles: The Netherlands and the Dutch East Indies at the world 1880-1931. Singapore: Singapore University Press.

Boland, B. J. (1971). The struggle of Islam in modern Indonesia. The Hague: Martinus Nijhof.

Bonab, R. G. (2009). Turkey's emerging role as a mediator on Iran's nuclear activities. Insight Turkey, 11(3), 161-175. Retrieved from http://files.setav.org/uploads/Pdf/insight_turkey_2009_3_rahman_bonab_turkey_e merging role as a mediator on irans nuclear activities.pdf

Borgen, C. J. (2008a). Introduction note to Kosovo's declaration of independence. International Legal Materials, 47(4), 461-466.

Borgen, C. J. (2008b). Kosovo's declaration of independence: Self-determination, secession and recognition. ASIL Insights, 12(2). Retrieved from American Society of International Law website: http://www.asil.org/insights/volume/12/issue/2/kosovos-declaration-independenceself-determination-secession

Boulton, G., \& Visoka, G. (2010). Recognizing Kosovo's independence: Remedial secession or earned sovereignty? Southeast East European Studies at Oxford: Ocassional Paper, 11(10), 1-24.

BPS, S. I. (2015). Statistical yearbook of Indonesia 2015. Jakarta: Statistics Indonesia.

Bruinessen, M. v. (2002). Geneologies of Islamic radicalism in post Suharto Indonesia. Southeast Asia Research, 10(2), 117-154.

Bruinessen, M. v. (2013a). Introduction: Contemporary developments in Indonesian Islam and the 'conservative turn of the early twenty first century. In M. v. Bruinessen (Ed.), Contemporary Developments in Indonesian Islam: Explaining the 'Conservative Turn (pp. 1-20). Singapore: ISEAS Publishing.

Bruinessen, M. v. (2013b). Overview of Muslim organizations, associations and movements in Indonesia. In M. v. Bruinessen (Ed.), Contemporary Developments 
in Indonesian Islam: Explaining the 'Conservative Turn (pp. 21-59). Singapore: ISEAS Publishing.

Budiwanti, E. (2001). Respon masyarakat Indonesia terhadap masalah Muslim di Bosnia, Kosovo, dan Chechnya (Indonesian society's response toward the problem of Muslims in Bosnia, Kosovo and Chechnya). In M. H. Basyar (Ed.), Indonesia dan problematika Muslim di Bosnia, Kosovo, dan Chechnya (Indonesia and the problem of Muslims in Bosnia, Kosovo and Chechnya) (pp. 153-176). Jakarta: Center for Political Research, Indonesian Institute of Sciences.

Bush, R. (2008). Regional sharia regulation in Indonesia: Anomaly or symptom? In G. Fealy \& S. White (Eds.), Expressing Islam: Religious life and politics in Indonesia (pp. 174-191). Singapore: ISEAS.

Bush, R. (2009). Nahdlatul Ulama and the struggle for power within Islam and politics in Indonesia. Singapore: ISEAS.

Butt, S. (2015). The constitutional court and democracy in Indonesia. Leiden: Brill Nijhoff.

Cahill, L. S. (2009). Religion and politics: USA. Theological Studies, 70(1), 186-191.

Camroux, D., \& Okfen, N. (2004). Introduction: 9/11 and US-Asian relations: towards a new 'New World Order'? The Pacific Review, 17(2), 163-177. Retrieved from http://dx.doi.org/10.1080/0951274042000219806

Carnegie, P. J. (2006). The political of Indonesia's Islamic identification. Dialogue, 4(1), 1-24.

Carnegie, P. J. (2008). Political Islam and democratic change in Indonesia. Asian Social Science, 4(11), 3-7. Retrieved from http://ccsenet.org/journal/index.php/ass/article/view/779/753

Cerone, J. (2009). Introductory note to United Nations General Assembly Resolution requesting an advisory opinion of the International Court of Justice on the unilateral declaration of independence of Kosovo and related documents. International Legal Materials, 48(1), 176-180.

Chalifah, G., \& Alkatiri, M. (2007). Pernyataan sikap PB pemuda al Irsyad (Statement of the position of the centralcommitee of the Al Irsyad youth) 26 March 2007. Al Irsyad Al Islamiyag. Retrieved from http://alirsyad.net/tag/pemuda-al-irsyadnuklir-iran/

Cheyfitz, E. (2014). The force of exceptionalist narratives in the Israeli-Palestinian conflict. Native American and Indigenous Studies, 1(2), 107-124. Retrieved from http://www.jstor.org/stable/10.5749/natiindistudj.1.2.0107

Chickrie, R. (2009, 6 April). Guyana making slow progress in advancing its agenda at OIC. Caribbean Muslims. Retrieved from http://www.caribbeanmuslims.com/blogs/16/Guyana-making-slow-progress-inadvancing-its-agenda-at-OIC.html

Chow, J. T. (2005). ASEAN counterterrorism cooperation since 9/11. Asian Survey, 45(2), 302-321. doi:10.1525/as.2005.45.2.302

Cigar, N., \& Clawson, P. (1999). The Arab world, Iran, and the Kosovo crisis. PolicyWatch, (391). Retrieved from The Washington Institute: Improving the Quality of US Middle East Policy website: http://www.washingtoninstitute.org/policy-analysis/view/the-arab-world-iran-andthe-kosovo-crisis

Clarke, M., \& White, B. (Eds.). (1989). Understanding foreign policy : The foreign policy systems approach. England: Edward Elgar.

Collins, N.-A. (2006, 10 May). Indonesia backs Iran's claim of peaceful nuclear program. $V O A$ 
http://search.proquest.com/docview/469974980?OpenUrlRefId=info:xri/sid:primo \&accountid $=14782$

Cooper, H., \& Brinnermay, E. (2011). Netanyahu gives no ground in Congress speech. The New York Times, 24 May. Retrieved from http://www.nytimes.com/2011/05/25/world/middleeast/25diplo.html? r=0

Coplin, W. D. (1971). Introduction to international politics: A theoretical overview. Chicago: Markham Publishing Company.

Cordesman, A. H., \& Al Rodhan, K. R. (2006). Iranian nuclear weapons? The uncertain nature of Iran's nuclear program. Working Paper. Center for Strategic and International Studies. Arleigh A. Burke Chair in Strategy. Retrieved from http://csis.org/files/media/csis/pubs/060412_iran_uncertainty.pdf

Cornell, S. E. (2006). Pakistan's foreign policy: Islamic or pragmatic? . In B. Shaffer (Ed.), The limits of culture: Islam and foreign policy (pp. 291-324). Cambridge, Masschusetts: The MIT Press.

Cornell, S. E. (2012). Changes in Turkey: What drives Turkish foreign policy? Middle East Quarterly, 19(1).

Cresswell, J. W. (2007). Qualitative inquiry and research design: Choosing among five approaches (Second ed.). Thousand Oaks, California: Sage Publications.

Cribb, R. (1992). Historical dictionary of Indonesia. Metuchen, NJ and London: The Scarecrow Press, Inc.

Cristi, M. (2001). From civil to political religion: The intersection of culture, religion and politics. Waterloo, Ontario, Canada: Wilfred Laurier University Press.

Croft, S. (2009). Religion and foreign policy. Renewal, 17(1).

Crouch, M. A. (2012). Law and religion in Indonesia: The constitutional court and the blasphemy law. Asian Journal of Comparative Law, 7, 1-46. Retrieved from http://dx.doi.org/10.1017/S2194607800000582

Curanovic, A. (2014). The religious factor in Russia's foreign policy. London: Taylor \& Francis.

Daily-Times. (2014, 11 Desember). Mushahid meets president Jokowi Daily Times. Retrieved from http://www.dailytimes.com.pk/national/11-Dec-2014/mushahidmeets-president-jokowi

Dalay, G., \& Friedman, D. (2013). The AK Party and the evolution of Turkish political Islam's foreign policy. Insight Turkey, 15, 123+. Retrieved from http://go.galegroup.com/ps/i.do?id=GALE\%7CA329302587\&v=2.1\&u=vuw\&it=r $\& \mathrm{p}=\mathrm{AONE} \& \mathrm{asid}=60 \mathrm{ef1e} 2778 \mathrm{e} 804265261 \mathrm{edee} 6866 \mathrm{f} 146$

Dalton, R. J. ( 2008. ). Citizen Politics, Public Opinion and Political Parties in Advanced Industrial Democracies (5th ed.). Washington, DC: Congressional Quarterly Press.

Daniels, T. (2007). Liberals, moderates and jihadists: protesting Danish cartoons in Indonesia. Contemporary Islam, 1(3), 231-246. Retrieved from http://dx.doi.org/10.1007/s11562-007-0020-0

Dark, K. R. (Ed.) (2000). Religion and international relations. New York: Palgrave.

Davis, L. E., Martini, J., Nader, A., Kaye, D. D., Quinlivan, J. T., \& Steinberg, P. (2011). Iran's nuclear future: Critical U.S. policy choices. Retrieved from Santa Monica, CA: http://www.rand.org/pubs/monographs/MG1087.html

Delpech, T. (2007). Iran and the bomb: The abdication of international responsibility. London: Hurst \& Company.

Delvoie, L. A. (1996). The Islamization of Pakistan's foreign policy. International Journal, 51(1), 126-147. Retrieved from http://www.jstor.org/stable/40203754 
Deplu. (2004). Rapat kerja menteri luar negeri dengan Komisi I Dewan Perwakilan Rakyat RI (Meeting between foreign minister and Commission I, DPR RI) 9 December 2004. Jakarta: Deplu (DFA) RI.

Deplu. (2005). Rapat kerja menteri luar negeri dengan Komisi I Dewan Perwakilan Rakyat RI (Meeting between foreign minister and Commission I, DPR RI) 30 November 2005. Jakarta: Deplu (DFA) RI.

Deplu. (2007). Rapat kerja menteri luar negeri dengan Komisi I Dewan Perwakilan Rakyat RI (Meeting between foreign minister and Commission I-DPR RI) 8 October 2007. Jakarta: Deplu (DFA) RI.

Deplu. (2007a). Rapat kerja menteri luar negeri dengan Komisi I Dewan Perwakilan Rakyat RI (Meeting between foreign minister and Commission I, DPR RI) on 8 October 2007. Jakarta.

Deplu. (2007b). Rapat kerja menteri luar negeri dengan Komisi I Dewan Perwakilan Rakyat RI (Meeting between foreign affairs and Commission I of DPR RI) 8 October 2007. Jakarta: Deplu (DFA) RI.

Deplu. (2009). Rapat kerja menteri luar negeri dengan Komisi I Dewan Perwakilan Rakyat RI (Meeting between minister for foreign affairs and DPR RI) 16 February 2009. Jakarta: Deplu (DFA) RI.

Detik. (2007, 31 March). Ba'asyir cs siap gugat SBY karena setujui resolusi Iran (Ba'asyir and friends got ready for court claims againts SBY due to his support to resolution on Iran). DetikNews. Retrieved from http://news.detik.com/berita/761301/baasyircs-siap-gugat-sby-karena-setujui-resolusi-iran

Dewaele, A., \& Pullinger, S. (2006). Nuclear crisis Iran. Europen Security Review: ISIS Europe(28), 1-3.

Djalal, D. P. (2007a, 8 April ). Resolusi 1747: Susah-susah gampang (Resolution 1747: Easy but difficult to realize). Majalah Tempo.

Djalal, D. P. (2007b, 28 March). RI, DK PBB, dan nuklir Iran (RI, the UNSC, and Iran's nuclear). Kompas. Retrieved from http://kompas.com/kompascetak/0703/28/opini/3413957.htm

Don-Yehiya, E. (1997). Religion, ethnicity and electoral reform: The religious parties and the 1996 elections. Israel Affairs, 4(1), 73-102. Retrieved from http://dx.doi.org/10.1080/13537129708719452

Dorraj, M. (2006). Behind Iran's nuclear pursuit? Peace Review: A Journal of Social Justice, $\quad 18, \quad 325-332 . \quad$ Retrieved from http://www.tandfonline.com/doi/pdf/10.1080/10402650600848258

Dosch, J. (2006). The impact of democratization on the making of foreign policy in Indonesia, Thailand, and the Philippines. Südostasien aktuell 5/2006, 5, 42-70.

Dowty, A. (2005). Israel/Palestine. Cambridge-UK: Polity.

DPR. (2004). Tata tertib DPR RI 2004-2009 (Rules of DPR RI 2004-2009). DPR RI.

DPR. (2007). Risalah rapat (Notes of the meeting) 15 May 2007.

DPR. (2011, August). DPR RI mendukung kemerdekaan Kosovo (House of Representative of Indonesia supports Kosovo's Indonesia ). Buletin Parlementaria (690).

Drajat, B. P. (2001). The Change of Indonesia's policy toward APEC (1989-1994): President Soeharto's role in foreign policy-making and diplomacy. (PhD), Hiroshima, Hiroshima, Japan.

Dueck, C., \& Takeyh, R. A. Y. (2007). Iran's nuclear challenge. Political Science Quarterly, 122(2), 189-205. Retrieved from http://dx.doi.org/10.1002/j.1538165X.2007.tb00596.x 
Duic, D. (2009). Analysis of the international community influence on Kosovo independence with emphasis on the EU role. Pravni vjesnik, 25 (3-4), 169-173.

Dumper, M. (2011). A false dichotomy? The binationalism debate and the future of divided Jerusalem. International Affairs, 87(3), 671-685. Retrieved from http://dx.doi.org/10.1111/j.1468-2346.2011.00996.x

Durkheim, E. (2001). The elementary forms of the religious life. In Susanne C. Monahan, William A. Mirola, \& M. O. Emerson (Eds.), Sociology of religion: A reader. New Jersey: Prentice Hall.

Edwin, N. (2007, 20 May). GP Ansor dukung interpelasi DPR soal nuklir Iran (GP Ansor supports the House's interpellation on sanctions againts Iran). DetikNews. Retrieved from http://news.detik.com/berita/782495/gp-ansor-dukung-interpelasidpr-soal-nuklir-iran

Effendy, B. (2003). Islam and the state in Indonesia. Singapore: ISEAS (Institute of Southeast Asian Studies).

ElBaradei, M. (2011). The age of deception: Nuclear diplomacy in treacherous times. London: Bloomsbury Publising Plc.

Eralp, D. U. (2010). Kosovo and Turkey: What lies ahead? SETA Policy Brief, November(50), 1-9.

Falk, R. (2011). The Kosovo advisory opinion: Conflict resolution and precedent. The American Journal of International Law, 105(1), 50-60. Retrieved from http://www.jstor.org/stable/10.5305/amerjintelaw.105.1.0050

Fardah. (2015, 22 February). CEAPAD II to focus on Palestine`s economic development capacity building. AntaraNews.com. Retrieved from http://www.antaranews.com/en/news/92811/ceapad-ii-to-focus-on-palestineseconomic-development-capacity-building

Farsakh, L. (2011). The one-state solution and the Israeli-Palestinian conflict: Palestinian challenges and prospect. The Middle East Journal, 65(1), 55-71.

Fatah, D. A. (2011). Perkembangan obligasi syariah (sukuk) di Indonesia: Analisis peluang dan tantangan (The development of syariah obligation in Indonesia: Analysis on opportunities and challenges). Al-Adalah, X(1), 35-46.

Fealy, G. (2001). Islamic politics: A rising or declining force? In D. Kingsbury \& A. Budiman (Eds.), Indonesia: The Uncertain Transition (pp. 119-136). Adelaide: Crawford House Publishing.

Fealy, G. (2003). Ijtihad politik ulama: Sejarah NU 1952-1967 (Ulama and politics in Indonesia: A history of Nahdlatul Ulama 1952-1967). Yogyakarta: LKiS.

Fealy, G. (2003b). Divided majority: Limits of Indonesian political Islam. In S. A. a. A. Saeed (Ed.), Islam and political legitimacy (pp. 150-168). London: Routledge Curzon.

Fealy, G. (2007a). Nurcholis Madjid: Remembering Indonesia's most preeminent Islamic reformer. Overland, 186, 48-53.

Fealy, G., Hooker, V., \& White, S. (2006). Indonesia. In G. F. a. V. Hooker (Ed.), Voices of Islam in Southeast Asia: A Contemporary sourcebook. Singapore: ISEAS.

Fealy, G., \& White, S. (Eds.). (2008). Expressing Islam: Religious life and politics in Indonesia. Singapore: ISEAS.

Federspiel, H. M. (1970). The Muhammadijah: A study of an orthodox Islamic movement in Indonesia. Indonesia(10), 57-79. Retrieved from http://www.jstor.org/stable/3350635

Federspiel, H. M. (1973). The Military and Islam in Sukarno's Indonesia. Pacific Affairs, 46(3), 407-420. Retrieved from http://www.jstor.org/stable/2756576 
Federspiel, H. M. (2001). Islam and ideology in the emerging Indonesian state: the Persatuan Islam (Persis), 1923-1957. Boston: Brill.

Feith, H. (1962). The decline of constitutional democracy in Indonesia. Ithaca, New York: Cornell University Press.

Fernandez, C. (2006, 4 August). Muslim leaders push peace role. The Age. Retrieved from http://www.theage.com.au/news/national/muslim-leaders-push-peacerole/2006/08/03/1154198271548.html

Fierstein, D. (2008). Kosovo's declaration of independence: An incident analysis of legality, policy and future implications. Boston University International Law Journal, 26(417), 417-441.

Filiu, J.-P. (2014). The twelve wars on Gaza. Journal of Palestine Studies, 44(1), 52-60. doi:10.1525/jps.2014.44.1.52

Flanagan, B. A. R. (2009). Islamic Realpolitik: Two Level Iranian Foreign Policy International Journal on World Peace, 26(4), 7.

Foniqi-Kabashi, B. (2008, 28/08). Kosovo seeks Arab states' recognition. SETimes.com. Retrieved from http://www.setimes.com/cocoon/setimes/xhtml/en_GB/features/setimes/features/20 $\underline{08 / 08 / 28 / \text { feature- } 02}$

Fox, J., \& Sandler, S. (2004). Bringing religion into international relations New York Palgrave Macmillan.

Frankel, J. (1970). National interest. London: Macmillan.

Freedman, A. L. (2009). Civil society, moderate Islam, and politics in Indonesia and Malaysia. Journal of Civil Society, 5(2), 107-127. doi:10.1080/17448680903154907

Friastuti, R. (2014, 22 November). Muhammadiyah dorong Indonesia akui Kosovo sebagai negara merdeka (Indonesia pushes Indonesia to recognize Kosovo as an independent state). DetikNews. Retrieved from http://news.detik.com/read/2014/11/22/173649/2756270/10/2/muhammadiyahdorong-indonesia-akui-kosovo-sebagai-negara-merdeka

Friedman, D. (2009). Christian Zionism and its Impact on US Foreign Policy. Religious Studies and Theology, 28(1).

Friel, H., \& Flak, R. (2007). Israel-Palestine on record. London: Verso.

Froese, P., \& Mencken, F. C. (2009). A US holy war? The effects of religion on Iraq war policy attitudes. Social Science Quarterly, 90(1).

Gaffas, B. T. (2008, 21 February). Ogah" akui Kosovo merdeka, Indonesia "sejajarkan" diri dengan Serbia (Reluctant to recognize Kosovo's independence, Indonesia equals with Serbia). Laskar Hijau Pejuang Syariah (The Green Warrior for Shariah). Retrieved from https://bulanbintang.wordpress.com/2008/02/21/\%E2\%80\%9Cogah\%E2\%80\%9Dakui-kosovo-merdeka-indonesia-\%E2\%80\%9Csejajarkan\%E2\%80\%9D-diridengan-serbia/

Gatra. (2001, 15 October). Pernyataan sikap pemerintah (The Government's position statement). Gatra.

Gatra. (2007, 28 March). Demonstran serahkan kambing ke DPR (Demonstrants handed a sheep to DPR). Gatra.com. Retrieved from http://arsip.gatra.com/2007-0328/artikel.php?id=103367

Gee, J. (2000a). Islam and the Middle East in the Far East: Despite denials, Indonesia greatly expanding economic ties with Israel. The Washington Report on Middle East Affairs, XIX(2), 57. Retrieved from http://search.proquest.com/docview/218805832?accountid=14782 
Gee, J. (2000b). Rocky start for new Indonesian president: Unrest in Aceh, challenge to Israel policy. The Washington Report on Middle East Affairs, XIX(1), 29. Retrieved from http://search.proquest.com/docview/218813716?accountid=14782

Gee, J. (2006, August 2006). Behind Indonesia's warm welcome for Iranian President Ahmadinejad. Washington Report on Middle East Affairs, pp. 38-39. Retrieved from http://www.wrmea.org/2006-august/behind-indonesias-warm-welcome-foriranian-president-ahmadinejad.html

Geertz, C. (1960). The religion of Java. London: The Free Press of Glencoe, CollierMcmillan.

Gentile, E. ( 2008). God's Democracy: American religion after September 11. Westport, CT: Praeger Publishers.

Gerring, J. (2004). What is a case study and what is it good for? American Political Science Review. Vol. 98, No. 2, May 2004., 98(2), 341-354.

Gindarsah, I. (2012a). Democracy and foreign policy making in Indonesia: A case study of the Iranian nuclear issue, 2007-08. Contemporary Southeast Asia, 34(3), 416-437.

Gindarsah, I. (2012b). Indonesia's democratic politics and foreign policy making: A case study of Iranian nuclear issue, 2007-2008. RSIS Working Paper(236), 1-28. Retrieved from https://www.rsis.edu.sg/wp-content/uploads/rsis-pubs/WP236.pdf

Goksoy, I. H. (2002). The policy of the Dutch government toward Islam in Indonesia. The American Journal of Islamic Social Sciences, 19(1), 73-94. Retrieved from http://vuw.summon.serialssolutions.com

Golan, G. (2007). Israel and Palestine: Peace plans and proposals from Oslo to disengagement. Princeton: Markus Wiener Publishers.

Green, J. C. (2007). The faith factor: How religion influences American elections. Westport: USA: Praeger Publishers.

Greenlees, D. (2007, 8 June). To gain among Muslims, Indonesia offers to mediate Middle East disputes. The New York Times. Retrieved from http://www.nytimes.com/2007/06/08/world/asia/08indo.html?fta=y\& r=0

Griffiths, M. ( 1999). Fifty key thinkers in international relations. London: Routledge.

Griffiths, M., O'Callaghan, T., \& Roach, S. C. (2002). International relations: The key concepts London and New York: Routledge.

Grovogu, S. (2011). A revolution nonetheless: The global south in international relations. The Global South, 5(1), 175-190. Retrieved from http://www.jstor.org/stable/10.2979/globalsouth.5.1.175

Gunadi, H., Febriana, B., \& Guritno, G. A. (2007, 11 April ). Sansi untuk Iran riakya di Senayan (Sanctions on Iran, its influence at Senayan). Gatra.

Guth, J. L. (2012). The religious roots of foreign policy exceptionalism. The Review of Faith \& International Affairs, 10(2), 77-85.

Habermas, J. (2006). Religion in the public sphere. European Journal of Philosophy, 14(1), 1-25. Retrieved from http://dx.doi.org/10.1111/j.1468-0378.2006.00241.x

Hafezi, P., \& Wroughton, L. (2015, 1 October). Normal ties between Iran and U.S. unlikely despite nuclear deal. Reuters. Retrieved from http://www.reuters.com/article/2015/10/01/us-un-assembly-iran-usa-insightidUSKCN0RV4CT20151001

Hagan, J. D. (1995). Domestic political explanations in the analysis of foreign policy. In L. Neack, J. A. K. Hey, \& P. J. Haney (Eds.), Foreign policy analysis : continuity and change in its second generation (pp. 117-144). New Jersey: Prentice Hall.

Hairgrove, F., \& Mcleod, D. M. (2008). Circles drawing toward high risk activism: The use of usroh and halaqa in Islamist radical movements. Studies in Conflict \& Terrorism, 31, 399-411. 
Hallward, M. (2011). Pursuing "peace' in Israel/Palestine. Journal of Third World Studies, 28(1), 185-202. Retrieved from http://search.proquest.com/docview/884214842?accountid=14782

Hannum, H. (2011). The advisory opinion on Kosovo: An opportunity lost, or a poisoned chalice refused? Leiden Journal of International Law, 24(01), 155-161. Retrieved from http://dx.doi.org/10.1017/S092215651000066X

Haqqani, H. (2004). The role of Islam in Pakistan's future. The Washington Quarterly, 28(1), 83-96. Retrieved from http://www.tandfonline.com/doi/abs/10.1162/0163660042518161

Haque, S. M. (2003). The revival of realism in international politics after September 11 and its ethical impact. International Journal of Politics and Ethics, 3(1), 135-155.

Harian-Terbit. (2007, 27 March). Ikut Menyetujui sanksi Iran, DPR ancam SBY (Supporting sanctions on Iran, the House threatens SBY). Harian Terbit. Retrieved from http://mahfudzsiddik.blogspot.co.nz/2007/04/ikut-menyetujui-sanksi-irandpr-ancam.html

Harvey, C. J., \& Sabatini, R. (2010). Russia's lukewarm support for international sanctions against Iran: History and motivations. NTI Building Safer World. Retrieved from http://www.nti.org/contact/

Hasan, N. (2005). September 11 and Islamic militancy in post-new order Indonesia In K. S. Nathan \& M. H. Kamali (Eds.), Islam in Southeast Asia: Political challenges for the 21st Century (pp. 301-324). Singapore: ISEAS.

Hasan, N. (2009). The making of public Islam: Piety, agency and commodification on the landscape of the Indonesian public sphere. Contemporary Islam, 3, 229-250.

Hasan, N. (2011). Political Islam in Indonesia. In I. Ahmed (Ed.), The Politics of Religion in South and Southeast Asia (pp. 136-156). Oxon: Routledge.

Hassan, M. Z. (1980). Diplomasi revolusi Indonesia di luar negeri (Indonesian 'revolution' diplomacy in foreign countries). Jakarta: Bulan Bintang.

Hatta, M. (1953). Indonesia's foreign policy. Foreign Affairs, 31(3), 441-452. doi: $10.2307 / 20030977$

Hatta, M. (1973). Introduction. In I. A. A. G. Agung (Ed.), Twenty years indonesian foreign policy. The Hague: Mouton.

Hatzopoulos, P., \& Petito, F. (2003). Religion in international relations: The return from exile. New York: Palgrave Macmillan.

Hayid, M. N. (2007, 26 March). Dukung sanksi PBB untuk Iran, pemerintah diinterpelasi DPR (supporting sanctions of UN toward Ira, the govt was interpellated by the House). DetikNews. Retrieved from http://hot.detik.com/read/2007/03/26/151101/758728/10/dukung-sanksi-pbb-untukiran-pemerintah-diinterpelasi-dpr

Haynes, J. (2008). Religion and poreign policy making in the USA, India and Iran: towards a research agenda. Third World Quarterly, 29(1), 143-165. Retrieved from http://dx.doi.org/10.1080/01436590701739668

He, K. (2008). Indonesia's foreign policy after Soeharto: International pressure, democratization, and policy change. International Relations of the Asia Pacific, 8, 47-72.

Hefner, R. W. (2000). Civil Islam: Muslims and democratization in Indonesia. Princenton, New Jersey: Princenton University Press.

Hefner, R. W. (2001). Public Islam and the problem of democratization. Sociology of Religion, 62(4), 491-514. 
Hendropriyono, D. (2009, 17 January). Indonesia should do more in Gaza. The Jakarta Post. Retrieved from http://www.thejakartapost.com/news/2009/01/17/indonesiashould-do-more-gaza.html

Hennink, M., Hutter, I., \& Bailey, A. (2011). Qualitative research methods. London: Sage Publications.

Hernawan, A. (2014, 10 July). Pemerintah RI kecam keras aksi militer Israel terhadap jalur Gaza (The Indonesian govt condemns Israel's military operation in the Gaza Strip). Lensa Indonesia.

Hilal, J. (2007). Palestine: The last colonial issue. In J. Hilal (Ed.), Where now for Palestine? The demise of two-state solution (pp. 1-29). London: Zed Books.

Hill, C. (2003). The changing politics of foreign policy. London: Palgrave Macmillan.

Hilmy, M. (2010). Islamism and democracy in Indonesia: Piety and pragmatism. Singapore: ISEAS.

Hilpold, P. (2009). The Kosovo case and international law: Looking for applicable theories. Chinese Journal of International Law, 8(1), 47-61. Retrieved from http://chinesejil.oxfordjournals.org/content/early/2009/01/26/chinesejil.jmn042.abs $\underline{\text { tract }}$

Hotland, T. (2008, 5 March). Indonesia abstains in UN vote on Iran The Jakarta Post. Retrieved from http://www.thejakartapost.com/news/2008/03/04/indonesiaabstains-un-vote-iran.html

Hotland, T., \& Khalik, A. (2009, January 07). Jihadists the last thing Gaza needs: Minister The Jakarta Post. Retrieved from http://www.thejakartapost.com/news/2009/01/07/jihadists-last-thing-gaza-needsminister.html

Houben, V. J. H. (2003). Southeast Asia and Islam. Annals of the American Academy of Political and Social Science, 588, 149-170. Retrieved from http://www.jstor.org/stable/1049859

HTI. (2008, 4 March). Kosovo belum sepenuhnya merdeka (Kosovo not really independent yet). Hizbut Tahrir Indonesia (HTI). Retrieved from http://hizbuttahrir.or.id/2008/03/04/kosovo-belum-sepenuhnya-merdeka/

Hunter, S. T. (2010). Iran's foreign policy in the post Soviet era: Resisting the new international order. Santa Barbara, California: Praeger.

Huntington, S. (1996). The clash of civilization and the remaking of world order. New York: Simon and Schuster.

Hussain, A. J. (2007). The media's role in a clash of misconceptions: The case of the Danish Muhammad cartoons. The Harvard International Journal of Press/Politics, 12(4), 112-130. Retrieved from http://hij.sagepub.com/content/12/4/112.abstract

IAEA, G. B. (2005). Implementation of the NPT safeguards agreement in the Islamic Republic of Iran. Retrieved from https://www.iaea.org/sites/default/files/gov200577.pdf

IAEA, G. B. (2006). Implementation of the NPT safeguards agreement in the Islamic Republic of Iran. Retrieved from https://www.iaea.org/sites/default/files/gov200653.pdf

Inbar, E. (2009). The rise and demise of the two-state paradigm. Orbis, 53(2), 265-283. Retrieved from http://www.sciencedirect.com/science/article/pii/S0030438709000088

Indarini, N. (2008, 19 February). Indonesia jangan ragu dukung kemerdekaan Kosovo (Indonesia should not hesitate to support Kosovo's independence). DetikNews. Retrieved from http://news.detik.com/berita/896130/indonesia-jangan-ragudukung-kemerdekaan-kosovo 
IndonesiaMatters. (2008, 22 February). Kosovo independence. Indonesia Matters. Retrieved from http://www.indonesiamatters.com/1618/kosovo-independence/

Islam, M. T. (2010). The logic behind Iran's uncompromising nuclear policy. Asia Journal of Global Studies, 4(2), 68-78. Retrieved from http://ajgs.org/index.php/AJGS/article/view/75/129

Jaber, T. (2010). A case for Kosovo? Self-determination and secession in the 21 st century. The International Journal of Human Rights, 15(6), 926-947. Retrieved from http://dx.doi.org/10.1080/13642981003666268

Jakarta-Post. (1999a, 25 March). Indonesia "regrets" airstrikes on Yugoslavia. The Jakarta Post. Retrieved from http://www.library.ohiou.edu/indopubs/1999/03/28/0040.html

Jakarta-Post. (1999b, 27 July). Kosovo bombing may affect region The Jakarta Post. Retrieved from http://m.thejakartapost.com/news/1999/07/27/kosovo-bombingmay-affect-region.html\#

Jakarta-Post. (1999d, 13 November). Critics say foreign policy overlooks Muslim interests The Jakarta Post. Retrieved http://www.thejakartapost.com/news/1999/11/13/critics-say-foreign-policyoverlooks-muslim-interests.html

Jakarta-Post. (1999e, 8 November). Discourse on Israel ties. The Jakarta Post. Retrieved from https://global.factiva.com/ha/default.aspx\#./!?\&_suid=14322767783510788601476 $\underline{9037117}$

Jakarta-Post. (1999f, 8 November). Indonesia-Israel ties discussed by Arab envoys The Jakarta Post. Retrieved from https://global.factiva.com/ha/default.aspx\#./!?\&_suid=14325192692770352933410 7315093

Jakarta-Post. (1999g, 15 November). Influential ulemas oppose planned ties with Israel. The Jakarta Post. Retrieved from http://www.thejakartapost.com/news/1999/11/15/influential-ulemas-opposeplanned-ties-with-israel.html

Jakarta-Post. (2005, 25 August). Susilo to visit U.S., Palestine in September The Jakarta Post. Retrieved from http://www.thejakartapost.com/news/2005/08/25/susilo-visitus-palestine-september.html

Jakarta-Post. (2006a, 27 May). US appreciates RI help on Iran. The Jakarta Post. Retrieved from http://www.indonesian-embassy.fi/in/filemanager/NV29Mei06.pdf

Jakarta-Post. (2006b, 8 May). Rally raises funds for cash-trapped Palestine The Jakarta Post. Retrieved from https://global.factiva.com/ha/default.aspx\#./!?\&_suid=14342758012070280677585 9737326

Jakarta-Post. (2007, 23 May). Indonesia faces dilemma over Kosovo. The Jakarta Post. Retrieved from http://www.b92.net/eng/news/politics.php?yyyy=2007\&mm=05\&dd=23\&nav_id= $\underline{41359}$

Jakarta-Post. (2008a, 14 March). Indonesia's nuclear diplomacy The Jakarta Post. Retrieved from http://www.thejakartapost.com/news/2008/03/13/editorialindonesia039s-nuclear-diplomacy.html\#sthash.oHbC3HUI.dpuf

Jakarta-Post. (2008b, 29 December ). Indonesian Muslims react to Israeli Gaza strike The Jakarta Post. Retrieved from http://www.thejakartapost.com/news/2008/12/29/indonesian-muslims-react-israeligaza-strike.html 
Jakarta-Post. (2009, 17 January). Yudhoyono disappointed on response to Gaza crisis The Jakarta Post. Retrieved from http://www.thejakartapost.com/news/2009/01/17/yudhoyono-disappointedresponse-gaza-crisis.html

Jakarta-Post. (2012, 18 May). Din urges Indonesia to recognize Kosovo The Jakarta Post. Retrieved from http://www.thejakartapost.com/news/2012/05/18/din-urgesindonesia-recognize-kosovo.html

Jamar, H., \& Vigness, M. K. (2010). Applying Kosovo: Looking to Russia, China, Spain and beyond after the International Court of Justice opinion on unilateral declarations of independence. German Law Journal, 11(08), 913-928.

James, B. (1973). Religious organization. Current Sociology, 21(2), 7-166.

Jaspal, R., \& Coyle, A. (2014). Threat, victimhood, and peace: Debating the 2011 Palestinian UN state membership bid. Digest of Middle East Studies, 23(1), 190214. Retrieved from http://dx.doi.org/10.1111/dome.12041

Jelen, T. G. (1994). Religion and foreign policy attitudes: Exploring the effects of denomination and doctrine American Politics Quarterly, 22(382).

Jia, B. B. (2009). The independence of Kosovo: A unique case of secession? Chinese Journal of International Law. Retrieved from http://chinesejil.oxfordjournals.org/content/early/2009/02/09/chinesejil.jmp003.abs $\underline{\text { tract }}$

Jones-Correa, M. A., \& Leal, D. L. (2001). Political participation: Does religion matter? Political Research Quarterly, 54(4), 751-770. Retrieved from http://prq.sagepub.com/content/54/4/751.abstract

Jonge, H. d. (1993). Discord and solidarity among the Arabs in the Netherlands East Indies, 1900-1942. Indonesia(55), 73-90. doi:10.2307/3351087

Jung, D. (2010). "Islam as problem": Dutch religious politics in the East Indies. Review of Religious Research, 51(3), 288-301. Retrieved from http://www.jstor.org/stable/20697346

Jung, D. (2011). The domestic context of new activism in Turkish foreign policy. International Journal(Winter 2011-2012).

Kaarbo, J., Lantis, J. S., \& Beasley, R. K. (2002). The analysis of foreign policy in comparative perspective. In R. K. Beasley, J. Kaarbo, J. S. Lantis, \& M. T. Snarr (Eds.), Foreign Policy in Comparative Perspective: Domestic and International Influences in State Behaviour. Washington: CQ Press.

Kanat, K. B. (2010). Ak party's foreign policy: Is Turkey turning away from the West. Insights Turkey, 12(1).

Katzman, K. (2012). Iran: U.S. concerns and policy responses. Retrieved from Washington: http://www.parstimes.com/history/crs_sept_12.pdf

Katzman, K. (2015). Iran's foreign policy. Retrieved from Washington: https://www.fas.org/sgp/crs/mideast/R44017.pdf

Katzman, K. (2015). Iran, gulf security, and U.S. policy. Retrieved from Washington: https://www.fas.org/sgp/crs/mideast/RL32048.pdf

Katzman, K., \& Kerr, P. K. (2015). Iran nuclear agreement. Retrieved from Washington: https://fas.org/sgp/crs/nuke/R43333.pdf

Kawilarang, R. (2012). GNB dicegah masuk Ramallah, Israel dikutuk (NAM denied to enter Ramallah, Israel condemned). viva.co.id, 6 August. Retrieved from http://dunia.news.viva.co.id/news/read/341965-gnb-dicegah-masuk-ramallah-israel-dikutuk 
KBRI-Belgrade. (2008). Statement of the government of the Republic of Indonesia on the unilateral declaration of independence by Kosovo [Press release]. Retrieved from www.indonesia.sk/press releases/2008/pr08-007

Kelman, H. C. (2011). A one-country/ two-state solution to the Israeli-Palestinian conflict. Middle East Policy, 18(1), 27-41. Retrieved from http://dx.doi.org/10.1111/j.14754967.2011.00471.x

Kemlu. (2005, 23 April ). Declaration on the New Asian-African Strategic Partnership. $\begin{array}{llll}\text { Kemlu } & \text { (MFA) RI. } & \text { Retrieved }\end{array}$ http://www.kemlu.go.id/Documents/NAASP/Hyperlink\%201.pdf

Kemlu. (2006). Rapat kerja menteri luar negeri dengan Komisi I Dewan Perwakilan Rakyat RI (Hearing between foreign minister and Commission I, DPR RI) on 20 March 2006. Jakarta: Kemlu (MFA) RI.

Kemlu. (2010). Foreign policy breakfasy 2002-2009. Jakarta: Kemlu (MFA) RI.

Kemlu. (2011a, 26 May). Indonesia proposes NAM's action plan to Palestine recognition. Kemlu (MFA) RI. Retrieved from http://www.kemlu.go.id/Pages/News.aspx?IDP=4832\&l=en

Kemlu. (2011b, 20 June). New Asian-African strategic partnership. Kemlu (MFA) RI. Retrieved

from http://www.kemlu.go.id/Pages/IFPDisplay.aspx?Name=RegionalCooperation\&IDP $=10 \& \mathrm{P}=$ Regional\&l=id

Kemlu. (2012a, 12 December). Kerja sama bilateral dengan Iran (Bilateral cooperation with Iran). Kemlu (MFA) RI. Retrieved from http://www.kemlu.go.id/Pages/IFPDisplay.aspx?Name=BilateralCooperation\&IDP $=30 \& \mathrm{P}=$ Bilateral $\& \mathrm{l}=\mathrm{id}$

Kemlu. (2012b). Upaya diplomatik/politik: Status Palestina di PBB (Diplomatic/political efforts: Status of Palestine in the UN). Kemlu (MFA) RI.

Kemlu. (2013). Status hubungan bilateral Indonesia-Serbia (Bilateral relations between Indonesia and Serbia). Kemlu (MFA) RI, 11 September.

Kemlu. (2014, 14 April). Isu Palestina (Palestinian issues) Kemlu (MFA) RI. Retrieved from

http://www.kemlu.go.id/Lists/InternationalIssues/DispForm.aspx?ID=15\&Content TypeId=0x0100DF3638C44EC4274F91993B85D9E15212

Kemlu. (2015). Strategi Indonesia untuk dialog lintas agama dan pemberdayaan kaum moderat (Indonesia's strategy on inter-religious dialogue and strenthening moderates). Kemlu (MFA) RI.

Ker-Lindsay, J. (2009). Kosovo: The path to contested statehood in the Balkans. London: I. B. Tauris.

Khalik, A. (2007a, 27 March). RI says Iran resolution prioritizes peaceful options The Jakarta Post. Retrieved from http://www.kbriislamabad.go.id/index2.php?option=com content\&task=view \&id=253\&pop=1\&pa $\mathrm{ge}=0$

Khalik, A. (2007b, 21 March). United States woos Indonesia vote on UN Iran resolution. The Jakarta Post. Retrieved from http://www.thejakartapost.com/news/2007/03/21/united-states-woos-indonesiavote-un-iran-resolution.html

Khalik, A. (2008, 20/02). RI has no reason to delay recognition of Kosovo: Analysts. The Jakarta Post. Retrieved from http://www.thejakartapost.com/news/2008/02/20/rihas-no-reason-delay-recognition-kosovo-analysts.html 
Khamaisi, R. (2010). The Israeli-Palestinian conflict: Building the future Palestine. Eurasian Geography and Economics, 51(6), 716-732. Retrieved from http://www.tandfonline.com/doi/abs/10.2747/1539-7216.51.6.716

Khan, A. S. (2006). Pakistan's foreign policy in the changing International scenario. The Muslim World, 96(2), 233-250. Retrieved from http://dx.doi.org/10.1111/j.14781913.2006.00126.x

Khan, M. S. (2015). The transformation of Turkish foreign policy in the Middle East. Policy Perspectives, 12(1), 31-50. Retrieved from http://www.jstor.org/stable/10.13169/polipers.12.1.0031\#pdf_only_tab_contents

Kholil, M. (2009). Dinamika Islam Golkar di era orde baru (Islamic dynamic of Golkar in the new order era). Tangerang: Gaya Media Pratama.

Kiblat. (2013, 12 June). Kunjungi Israel, Habib Rizieq desak Tantowi Yahya dipecat dari DPR RI dan partai Golkar (Visiting Israel, Habib Rizieq urged Tantowi Yahya to be fired by DPR RI and Golkar party). Kiblat.Net. Retrieved from http://www.kiblat.net/2013/06/13/kunjungi-israel-habib-rizieq-desak-tantowiyahya-dipecat-dari-dpr-ri-dan-partai-golkar/

Kompas. (2007, 27 March). Usulan perubahan RI diterima (The proposed amendment of RI was accommodated). Kompas. Retrieved from C:IUserslalanshmo.STAFF.000\Downloadsldigital_blob_F31457_Usulan Perubahan RI Diterima.htm

Korver, A. P. E. (1988). The Islamic movement. In C. W. a. P. Carey (Ed.), Born in Fire: The Indonesian struggle for indepence, an anthology. Athens, USA: Ohio University Press.

KosovaPress. (2008, 20 June). OIC foreign affairs divided on recognition of Kosovo. Press. Retrieved from http://www.kosovapress.com/archive/?cid=2,26,47784

Kosovothanksyou. (2009, 2 April). Indonesia open towards recognition of Kosovo. Kosovo Thank You. Retrieved from http://www.kosovothanksyou.com/news/?p=377

Kosovothanksyou. (2015, 20 May). Who recognized Kosovo as an independent state? The Kosovar people thank you. Kosovothanksyou.com. Retrieved from http://www.kosovothanksyou.com/

Krasniqi, G. (2011). The 'forbidden fruit': Islam and politics of identity in Kosovo and Macedonia. Southeast European and Black Sea Studies, 11(2), 191-207. Retrieved from http://dx.doi.org/10.1080/14683857.2011.587285

kryeministri-ks. (2012, 15 June). The prime minister of the Republic of Kosovo Hashim Thaçi meets the foreign minister of Saudi Arabia, Saud Bin Fejsal. The Office of the Priminister-the Republic of Kosovo. Retrieved from http://www.kryeministriks.net/?page $=2,9,293$

Kutaisha, A. M. (2006). Islam in Malaysian foreign policy under the premiership of Dr. Mahathir Bin Mohamad. (Master of Social Sciences in Strategy and Diplomacy), University Kebangsaan Malaysoa, Kuala Lumpur.

Lacey, T. (2009, 28 January). Indonesia, Palestine and the way forward The Palestine Chronicle. Retrieved from http://www.palestinechronicle.com/indonesia-palestineand-the-way-forward/

Lamb, K. (2012, 25 September). Indonesia's president to propose global blasphemy protocol. Voice of America.

Landler, M. (2009, 18 February). Clinton praises Indonesian democracy. The New York Times.

from http://www.nytimes.com/2009/02/19/washington/19diplo.html? r=0 
Lee, J. (2004). The failure of political Islam in Indonesia: A historical narrative Stanford Journal of East Asian Affairs, 4(1 (Winter)), 85-104.

Leifer, M. (1983a). Indonesia's foreign policy. London: George Allen\& Unwin.

Leifer, M. (1983b). The Islamic factor in Indonesia's foreign policy: A case of functional ambiguity. In A. Dawisha (Ed.), Islam in foreign policy (pp. 144-159). Cambridge: Cambridge University Press.

Lev, D. S. (1966). The transition to guided democracy: Indonesian politics, 1957-1959 Ithaca, New York: Southeast Asia Program, Department of Asian Studies, Cornell University.

Lev, D. S. (1967). Political parties in Indonesia. Journal of Southeast Asian History, 8(1), 52-67. Retrieved from http://www.jstor.org/stable/20067612

Liddle, R. W. (1992). Indonesia's democratic past and future. Comparative Politics, 24(4), 443-462. Retrieved from http://www.jstor.org/stable/422154

Liddle, R. W. (1996). The Islamic turn in Indonesia: A political explanation. The Journal of Asian Studies, 55(3), 613-634. Retrieved from http://www.jstor.org/stable/2646448

Liddle, R. W. (2003). New patterns of Islamic politics in democratic Indonesia. Asia Program Special Report(110), 4-13.

Liddle, R. W., \& Mujani, S. (2013). Indonesian democracy: From transition to consolidation. In M. Künkler \& A. Stepan (Eds.), Democracy and Islam in Indonesia (pp. 24-50). New York: Columbia University Press.

Lie, J. (2008). Diplomasi Indonesia menghadapi reaksi terhadap publikasi karikatur Nabi Muhammad di Jyllands-Posten (Indonesia's diplomacy to face reaction on the publication of Prophet Muhammad's carricatures in Jyllands-Posten). Jurnal Ilmiah Hubungan Internasional, 4(1), 44-62.

Lindekilde, L., Per Mouritsen and Ricard Zapata-Barrero. (2009). The Muhammad cartoons controversy in comparative perspective. Ethnicities 2009; 9; 291, 9(291), 292-313.

Lindholm, K., \& Olsson, E.-K. (2011). Crisis communication as a multilevel game: The Muhammad cartoons from a crisis diplomacy perspective. The International Journal of Press/Politics, 16(2), 254-271. Retrieved from http://hij.sagepub.com/content/16/2/254.abstract

Liong, L. S. (1988). Indonesian Muslims and the state accommodation or revolt? Third World Quarterly, 10(2), 869-896.

Lomagin, N. (2012). Interest groups in Russian foreign policy: The invisible hand of the Russian Orthodox Church. International Politics, 49(4), 498-516. Retrieved from http://dx.doi.org/10.1057/ip.2012.13

Lukens-Bull, R., \& Woodward, M. (2011). Goliath and David in Gaza: Indonesian mythbuilding and conflict as a cultural system. Contemporary Islam, 5(1), 1-17. Retrieved from http://dx.doi.org/10.1007/s11562-010-0145-4

Maghribi, C. (2007, 5 April). Diplomasi mengabdi RI pada AS (The serving diplomacy of the RI to the US). Suara Merdeka. Retrieved from http://www.suaramerdeka.com/harian/0704/05/opi04.htm

Maharani, E. (2014, 25 September). UU jaminan produk halal disahkan setelah menunggu delapan tahun (Law on guarantee of halal product was endorsed after waiting for eight years). Republika Online. Retrieved from http://www.republika.co.id/berita/nasional/umum/14/09/25/ncg1tk-setelah-8-tahunruu-jph-disahkan

Makyanie, M. S. (2014, 23 September). Delegasi DPR-RI terpaksa pulang batal kunjungi Gaza (DPR RI delegation cancelled visit to Gaza). AntaraNews.com. Retrieved 
from http://www.antaranews.com/berita/455042/delegasi-dpr-ri-terpaksa-pulangbatal-kunjungi-gaza

Malley, M. S. (2002). Indonesia in 2001: Restoring stability in Jakarta. Asian Survey, 42(1), 124-132.

Retrieved

from

http://www.jstor.org/stable/10.1525/as.2002.42.1.124

Manza, J., \& Brooks, C. (1997). The religion factor in US presidential election, 19601992. American Journal of Sociology, 103(1).

Manza, J., \& Wright, N. (2003). Religion and political behavior. In M. Dillon (Ed.), Handbook of the sociology of religion New York: Cambridge University Press.

Marjani, G. I. (2012). Wajah toleran NU: Sikap NU terhadap kebijakan pemerintah atas umat Islam (The tolerant face of NU: NU's stance on the government policies towards Muslim). Jakarta: Semesta Rakyat Merdeka.

Marsden, L. (2011). Religion, identity and American power in the age of Obama International Politics, 48( 2/3), 326-343.

Marsudi, R. L. (2015). Annual press statement-Ministry foreign affairs of RI. Kemlu (MFA) RI, 8 January

Maruli, A. (2013, 24 June). Tantowi Yahya: Saya yang terdepan membela Palestina (Tantowi Yahya: I am in the front for defending Palestine). AntaraNews.com. Retrieved from http://www.antaranews.com/suara-parlemen/berita/381746/tantowiyahya-saya-yang-terdepan-membela-palestina

Mashad, D. (2008). Politik luar negeri Indonesia era reformasi (Indonesia's foreign policy in the reform Era). In G. Wuryandari (Ed.), Politik luar negeri Indonesia di tengah pusaran politik domestik (Indonesia's Foreign Policy in the Middle of the domestic politics vortex). Yogyakarta: Pustaka Belajar.

Mayan, M. J. (2001). An introduction to qualitative methods: A training for students and professionals. Canada: International Institute for Qualitative Methodology, University of Alberta, Canada.

Mehden, F. R. v. d. (1993). Two worlds of Islam: Interaction between Southeast Asia and the Middle-East. Florida: University Press of Florida.

Merdeka. (2007, 24 July). Indonesia tolak pemaksaan keputusan untuk Kosovo (Indonesia rejects the forced decision on Kosovo). merdeka.com. Retrieved from http://www.merdeka.com/politik-nasional/indonesia-tolak-pemaksaan-keputusanuntuk-kosovo-zfqalce.html

MFA-KS. (2013). Hoxhaj seeks Kosovo's recognition by Egypt and Arab League countries Ministry of Foreign Affairs-Republic of Kosovo. 14 Januari 2013. Retrieved from http://www.mfa-ks.net/?page=2,4,1562

MFA-KS. (2014). Minister Hoxhaj called OIC member countries to recognize Kosovo. Ministry of Foreign Affairs-Republic of Kosovo. 19 June 2014. Retrieved from http://www.mfa-ks.net/?page $=2,4,2368$

Miller, P. D. (2014). Evangelicals, Israel and US foreign policy. Survival, 56(1), 7-26. Retrieved from http://dx.doi.org/10.1080/00396338.2014.882149

Minkenberg, M. (2010). Party politics, religion and elections in Western democracies. Comparative European Politics, 8(4), 385-414. Retrieved from http://dx.doi.org/10.1057/cep.2009.5

Mochtar, Z. A. (2014, 9 December). A suitable interpellation The Jakarta Post. Retrieved from interpellation.html

Monshipouri, M. (2013). Iran's foreign policy and Islamic ideology. In T. Juneau \& S. Razavi (Eds.), Iranian foreign policy since 2001: Alone in the world (pp. 56-69). Abingdon, Oxon: Routledge. 
Moravcsik, A. (1997). Taking preferences seriously: A liberal theory of international politics. International Organization, 51(04), 513-553. Retrieved from http://dx.doi.org/10.1162/002081897550447

MPR. (2014, 21 November). Kosovo berharap pengakuan kemerdekaan dari Indonesia (Kosovo hopes the recognition of its independence from Indonesia). MPR-RI. Retrieved from https://www.mpr.go.id/berita/read/2014/11/24/13816/kosovoberharap-pengakuan-kemerdekaan-dari-indonesia

Muftisani, H. (2012, 24 November). LazisMU akan bangun sekolah Muhammadiyah di Gaza (LazisMU would build a school of Muhammadiyah in Gaza). Republika Online. Retrieved from http://www.republika.co.id/berita/nasional/umum/12/11/24/mdznlk-lazismu-akanbangun-sekolah-muhammadiyah-di-gaza

Muhaj. (2007, 1 April). Gus Dur : Jangan emosional sikapi resolusi DK PBB soal Iran (Gus Dur: Don't be emotional in responding UNSC resolution on Iran). AntaraNews.com. Retrieved from http://www.antaranews.com/berita/57670/gusdur--jangan-emosional-sikapi-resolusi-dk-pbb-soal-iran

Muhammadiyah, C. E. B. (2010). 1 abad Muhammadiyah: Gagasan pembaharuan sosial keagamaan (1 century of Muhammadiyah: Ideas of social-religious modernity). Jakarta: Kompas.

Muhammadiyah, C. E. B. (2012, 18 May). Presiden Kosovo terima kunjungan Din Syamsudin (President of Kosovo received Din Syamsuddin). Pimpinan Pusat Muhammadiyah (Central Executive Board of Muhammadiyah). Retrieved from http://www.muhammadiyah.or.id/id/news-1166-detail-presiden-kosovo-terimakunjungan-din-syamsudin.html

Muhammadiyah, C. E. B. (2013, 16 May). Muhammadiyah dukung penuh Kosovo (Muhammadiyah fully supports Kosovo). Pimpinan Pusat Muhammadiyah (Central Executive Board of Muhammadiyah). Retrieved from http://www.muhammadiyah.or.id/id/news-2656-detail-muhammadiyah-dukungpenuh-kosovo.html

Muharremi, R. (2008). Kosovo's declaration of independence: self-determination and sovereignty revisited. REview of Central and Eastern European Law, 33(4), 401$435 . \quad$ Retrieved from http://booksandjournals.brillonline.com/content/journals/10.1163/157303508x3396 $\underline{89}$

Muharremi, R. (2010). A note on the ICJ advisory opinion on Kosovo. German Law Journal, 11(8), 865-880.

MUI. (2011, 10 August). Kosovo butuh pengakuan negara Muslim (Kosovo needs the recognition from Muslim state). Majelis Ulama Indonesia (Indonesian Council of Ulama). Retrieved from http://mui.or.id/mui/homepage/berita/beritasingkat/kosovo-butuh-pengakuan-negara-muslim.html

Mujani, S., \& Liddle, R. W. (2009). Muslim Indonesia's secular democracy. Asian Survey, 49, 575-590.

Mujani, S., \& Liddle, R. W. (2010). Voters and the new Indonesian democracy. In E. Aspinal \& M. Mietzner (Eds.), Problems of democratisation in Indonensia: Elections, institutions and society (pp. 75-99). Singapore: ISEAS.

Mujani, S., Liddle, R. W., \& Ambardi, K. (2011). Kuasa rakyat: Analisis tentang perilaku memilih dalam pemilihan legislatif dan presiden Indonesia pasca order baru (Power of the people: Analysis on voters behaviour on legislative and presidential election of Indonesia in the post new order). Bandung: Mizan. 
Murphy, A. M. (2009). Indonesia returns to the international stage: Good news for the United States. Orbis, 53(1), 65-79. Retrieved from http://www.sciencedirect.com/science/article/pii/S0030438708000896

Murphy, A. M. (2010). US raproachement with Indonesia: From problem state to partner. Contemporary Southeast Asia, 32(3), 362-387.

Murphy, A. M. (2012). Democratization and Indonesian foreign policy: Implications for the United States. Asia Policy, 13(1), 83-111.

MuslimDaily. (2013, 17 May). Indonesia enggan akui Kosovo (Indonesia reluctant to recognize Kosovo). Muslimdaily.net. Retrieved from http://www.muslimdaily.net/berita/nasional/indonesia-enggan-akui-kosovo.html

Muttaqien, M. (2013). Domestic politics and Indonesia's foreign policy on the Arab-Israel conflict. Global \& Strategis, 7 (1 (Januari-Juni)), 57-72.

Myers, S. L. (2011). Divisions are clear as Obama and Netanyahu discuss peace. The New York Times, 20 May. Retrieved from http://www.nytimes.com/2011/05/21/world/middleeast/21prexy.html?action=click \&contentCollection $=$ Middle $\% 20$ East $\&$ module $=$ RelatedCoverage $\&$ region=Margina lia\&pgtype $=$ article

myQuran. (2011, 09 August). Muhammadiyah Dorong Kosovo Minta Pengakuan Kemerdekaan RI (Muhammadiyah pushes Kosovo to ask the recognition of independence from RI). Retrieved from http://myquran.or.id/forum/showthread.php/66178-Muhammadiyah-DorongKosovo-Minta-Pengakuan-Kemerdekaan-RI

Mzioudet, H. (2013, 26 September). Libya officially recognises Kosovo. Libya Herald. Retrieved from http://www.libyaherald.com/2013/09/26/libya-officiallyrecognises-kosovo/\#axzz3P9a7KfV7

Nair, S. (1997). Islam in Malaysian foreign policy. London and New York: Routledge.

Nasihin. (2012). Sarekat Islam mencari ideology 1924-1945 (Sarekat Islam was in search of Ideology in the period of 1924-1945). Yogyakarta: Pustaka Pelajar.

Nasr, V. (2005). The rise of Muslim democracy. Journal of Democracy, 16(2).

Nassar, G. (2008, 6-12 March). Deferring recognition of Kosovo. Al Ahram Weekly Online. Retrieved from http://weekly.ahram.org.eg/2008/887/op3.htm

Natalegawa, M. M. (2011). Statement by H.E. Dr. R.M. Marty M. Natalegawa, Minister for Foreign Affairs, Republic of Indonesia at the 67th Session of the UN General Assembly, agenda item 37: Questions of Palestine, New York, 29 November 2011.

Natalegawa, M. M. (2014). Annual press statemen- Minister for foreign affairs of RI. Kemlu (MFA) RI, 7 January.

Nessman, R. (2006, 2006 Aug 27). Israel asks some Muslims to join UN Lebanon force. Pittsburgh Post - Gazette, pp. A-2. Retrieved from http://search.proquest.com/docview/390816471?accountid=14782

Nevo, Z. a. M., Tamar (2009). Lessons from Kosovo: The law of statehood and Palestinian unilateral independence. Journal of International Law and International Relations, 5(2), 89-115.

Nhina Le Thi, M. H. (2009) The Gaza crisis: Impact on Southeast Asia. RSIS Commentaris No. 015 (pp. 1-3). Singapore: Nanyang Technological University.

Nia, M. M. (2010). Understanding Iran's foreign Policy: An application of holistic constructivism. Alternatives: Turkish Journal of International Relations, 9(9), 148180.

Nicolli, A., \& Delaney, J. (2007). Iran's nuclear programme: Can diplomacy succeed? IIS Strategic Comments, 13(3), 1-2. Retrieved from 
http://www.iiss.org/en/publications/strategic\%20comments/sections/2007d2a0/iran--39-s-nuclear-programme-88fd

Noer, D. (1978). The modernist Muslim movement in Indonesia 1900-1942. London: Oxford University Press.

Novel, \& Nuol. (2008, 23 February). PBNU minta pemerintah akui kemerdekaan Kosovo (NU asks the government to recognize Kosovo). eramuslim. Retrieved from http://www.eramuslim.com/berita/nasional/pbnu-minta-pemerintah-akuikemerdekaan-kosovo.htm

NU-Online. (2007a, 30 March). Gus Dur Gugat Nuklir Israel (Gus Dur would sue Israel's nuclear). $N U$ Online. Retrieved from http://www.nu.or.id/a,public-m,dinamics,detail-ids, 1-id,8572-lang,id-c, warta-t,Gus+Dur+Gugat+Nuklir+Israel-.phpx

NU-Online. (2007b, 27 March). Gus Dur: Indonesia takut pada AS soal sanksi Iran (Gus Dur: Indonesia is afraid of the US on the Iranian sanctions). NU Online. Retrieved from http://www.nu.or.id/a,public-m,dinamic-s,detail-ids,1-id,8534-lang,idc,warta-t,Tawadhu-.phpx

NU-Online. (2007c, 27 March). Iran lebih menghargai dukungan PBNU (Iran more appreciated support from NU). NU Online. Retrieved from http://www.nu.or.id/a,public-m,dinamic-s, detail-ids,1-id,8538-lang,id-c,wartat,Iran+Lebih+Menghargai+Dukungan+PBNU-.phpx

NU-Online. (2007d, 27 March). Menlu bantah ada tekanan Barat tentang sanksi Iran (Foreign Minister denied the pressure from the West on sanctions against Iran). $N U$ Online. Retrieved from http://www.nu.or.id/a,public-m,dinamic-s,detail-ids,1id,8535-lang,id-c, warta-t,Tawadhu-.phpx

NU-Online. (2007e, 31 march). Muslimat NU tolak dukung resolusi PBB (The NU woman association rejects to support the UNSC Resolution). NU Online. Retrieved from http://www.nu.or.id/a,public-m,dinamic-s, detail-ids,1-id,8560-lang,id-c,wartat,Muslimat+NU+Tolak+Dukung+Resolusi+PBB-.phpx

NU-Online. (2007f, 22 March). NU bela Iran, AS tawari kerja sama (NU defends Iran, the US offers cooperation). NU Online. Retrieved from http://nu.or.id/a,publicm,dinamic-s, detail-ids, 1-id,8490-lang,id-c,wartat,NU+Bela+Iran++AS+Tawari+Kerja+Sama-.phpx

NU-Online. (2007g, 20 June). NU sarankan presiden hadiri interpelasi DPR soal Iran (NU suggests the president to attend the House' interpellation). Retrieved from http://www.nu.or.id/a,public-m,dinamic-s, detail-ids, 1-id,9278-lang,id-c,wartat,PBNU+Sarankan+Presiden+Hadiri+Interpelasi+DPR+Soal+Iran-.phpx.

NU-Online. (2007h, 26 March). PBNU diprotes tokoh-tokoh Muslim sedunia soal sanksi Iraq (The central committee of NU was protested by Muslim world leaders on sanctions against Iran) $N U$ Online. Retrieved from http://www.nu.or.id/a,public$\underline{\text { m,dinamic-s,detail-ids,1-id,8527-lang,id-c,warta- }}$ t,PBNU+Diprotes+Tokoh+tokoh+Muslim+Dunia+Soal+Sanksi+Iran-.phpx

Nu-Online. (2007i, 28 March). PBNU Dukung Interpelasi DPR Soal Iran (The central committee of NU supports the House's interpellation rights on Iran). NU Online. Retrieved from http://www.nu.or.id/a,public-m,dinamic-s,detail-ids,1-id,8545lang,id-c,warta-t,PBNU+Dukung+Interpelasi+DPR+Soal+Iran-.phpx.

NU-Online. (2007j, 26 March). PBNU kecam sikap RI soal sanksi terhadap Iran (The central committee of the NU condemns Indonesia's position on sanctions against Iran). NU Online. Retrieved from http://www.nu.or.id/a,public-m,dinamic-s,detailids, 1-id,8526-lang,id-c,warta-

t,PBNU+Kecam+Sikap+RI+Soal+Sanksi+terhadap+Iran-.phpx 
NU-Online. (2007k). PBNU: Resolusi DK PBB efektif untuk dunia Islam, tidak bagi Israel (The central committee of NU: UNSC resolution only works for the Muslim world, not for Israel). NU Online. Retrieved from http://www.nu.or.id/a,publicm,dinamic-s, detail-ids,1-id,9117-lang,id-c,warta-

t,PBNU++Resolusi+DK+PBB+Efektif+untuk+Dunia+Islam++Tidak+bagi+Israel.phpx

NU-Online. (20071, 4 June). PMII: Bukan sidang komisi, presiden harus datang langsung (PMII: Not the House's commission meeting, the president should attend) $N U$ Online. Retrieved from http://www.nu.or.id/a,public-m,dinamic-s,detail-ids,1id,9128-lang,id-c,warta-

t,PMII++Bukan+Sidang+Komisi++Presiden+Harus+Datang+Langsung-.phpx

NU-Online. (2008, 21 February). PBNU undang ulama Kosovo pada ICIS III (The NU Invites Kosovo at ICIS III). NU Online. Retrieved from http://www.nu.or.id/a,public-m,dinamic-s, detail-ids,1-id,11358-lang,id-c,wartat,PBNU+Undang+Ulama+Kosovo+pada+ICIS+III-.phpx

Nugraha, I. (2012, 21 November ). Ribuan santri Tasik suarakan bakar antek Israel (Thousands of pious Muslim student voice to burn henchman of Israel). Kompas.com. Retrieved from http://internasional.kompas.com/read/2012/11/21/14024638/twitter.com

Nye, J. S. (1999). Redefining the national interest. Foreign Affairs, 78(4), 22-35. doi: $10.2307 / 20049361$

Öcal, M., \& Çelenk, A. A. (2010). Making of a new state in the Balkans: Kosovo. Insight Turkey, 12(4), 167-183.

Oded, A. (2010). Africa in Israeli foreign Policy-expectations and disenchantment: Historical and diplomatic aspects. Israel Studies, 15(3), 121-142. Retrieved from http://www.jstor.org/stable/10.2979/ISR.2010.15.3.121

OIC. (1972). Charter of Islamic Conference, adopted by 3rd Islamic Conference of Foreign Minister in Jeddah, 4 March 1972. No. 13039 Multilateral. Retrieved from https://treaties.un.org/doc/Publication/UNTS/Volume\%20914/volume-914-I13039-English.pdf

Okezone. (2008). SBY: Sikap abstain soal sanksi atas Iran independent (SBY: Abstention on sanction against Iran was independent). Okezone.com. Retrieved from http://www.muhsinlabib.com/news/sby-sikap-abstain-ri-soal-sanksi-atas-iranindependen

Onis, Z. (2009). The new wave of foreign policy activism in Turkey: Drifting away from Europenization. Danish Institute for International Studies Report, 9.

Orakhelashvili, A. (2008). Statehood, recognition and the United Nations system: A unilateral declaration of independence in Kosovo. In A. v. B. a. R. Wolfrum (Ed.), Max Planck Yearbook of United Nations Law (Vol. 2, pp. 1-44). The Netherland: Konninklijke Brill N.V.

Pande, A. (2010). Foreign policy of an ideological state: Islam in Pakistan's international relations. (PhD Degree), Boston University, Ann Arbor.

Pappe, I. (2007). Zionism and the two-state solution. In J. Hilal (Ed.), Where now for Palestine? The demise of two-state solution (pp. 30-47). London: Zed Books.

Paris, J. (1996). Step-by-step towards Indonesian-Israeli relations. Israel Affairs, 3(2), 111119.

Parnohadiningrat, S. (2005). Indonesia and Iran's nuclear issue. In K. Indriana (Ed.), Indonesia and Iran's nuclear issue (pp. 1-8). Jakarta: LIPI Press.

Patrikios, S. (2008). American republican religion? Disentangling the causal link between religion and politics in the US. Political Behavior, 30(3), 367-389. Retrieved from 
http://helicon.vuw.ac.nz/login?url=http://search.ebscohost.com/login.aspx?direct=tr $\underline{\mathrm{ue} \& \mathrm{db}=\mathrm{pbh} \& \mathrm{AN}=33436886 \& \text { site }=\text { ehost-live }}$

Patterson, E., \& Mason, R. (2007). Why Kosovo doesn't matter, and how it should. International Politics, 47(1), 91-103. Retrieved from http://dx.doi.org/10.1057/ip.2009.30

PBNU. (2009, 05 January 2009). Pernyataan dan sikap PBNU atas serangan Israel terhadap Palestina (PBNU's statement on the Israeli attack on Palestine). $N U$ Online. Retrieved from http://www.nu.or.id/a,public-m,dinamic-s,detail-ids,6id,15428-lang,id-c,taushiyah-

t,Pernyataan+dan+Sikap+PBNU+atas+Serangan+Israel+terhadap+Palestina-.phpx

PBNU. (2013). Role of ulama in peace and reconciliation of Afghanistan Retrieved from

Pearson, M. N. (1990). Conversions in South-east Asia: Evidence from the Portuguese records. Portuguese Studies, 6, 53-70. Retrieved from http://www.jstor.org/stable/41104904

Perthes, V. (2010). Ambition and fear: Iran's foreign policy and nuclear programme. Survival, 52, June-July(3), 95-114.

Perwita, A. A. B. (2007). Indonesia and the World Muslim: Islam and secularism in the foreign policy of Soeharto and beyond. Copenhagen, Denmark: NIAS Pers.

Philpott, D. (2002). The Challenge of September 11 to secularism in international relations. World Politics, 55(1), 66-95.

Philpott, D. (2007). Explaining the political ambivalence of religion. American Political Science Review, 101(03), 505-525. Retrieved from http://dx.doi.org/10.1017/S0003055407070372

Pippan, C. (2010). The International Court of Justice's advisory opinion on Kosovo's declaration of independence: an exercise in the art of silence. Europäisches Journal für Minderheitenfragen, 3(3-4), 145-166. Retrieved from http://dx.doi.org/10.1007/s12241-010-0080-x

Piscatori, J. (1983). Islamic values and national interests: The foreign policy of Saudi Arabia. In A. Dawisha (Ed.), Islam in foreign policy (pp. 33-53). Cambridge: Cambridge University Press.

Pitsuwan, F. (2012). Indonesia's foreign policy and the international politics of the Islamic world. The Indonesian Quarterly, 40(4), 331-351.

Pitsuwan, F. (2014). Smart power strategy: Recalibrating Indonesian foreign policy. Asian Politics \& Policy, 6(2), 237-266. Retrieved from http://dx.doi.org/10.1111/aspp.12107

Porter, D. J. (2002). Managing politics and Islam in Indonesia. London: RoutledgeCurzon.

Powers, S. (2008). Examining the Danish cartoon affair: mediatized cross-cultural tensions? Media, War \& Conflict, 1(3), 339-359. Retrieved from http://mwc.sagepub.com/content/1/3/339.abstract

Prasetyo, B. (2011, 28 September). Meski AS "memveto" Palestina tetap diakui (Although the US vitoed, Palestina remains recognized). AntaraNews.com Retrieved from http://www.antaranews.com/berita/277417/meski-as-memvetopalestina-tetap-diakui

PRC. (2015, August ). Global indicator database: Opinion of Iran. Retrieved from http://www.pewglobal.org/database/indicator/25/country/101/

Press, T. P. R. C. F. T. P. T. (2002). The Pew Global attitudes project: What the world thinks in 2002. Retrieved from http://www.pewglobal.org/files/2002/12/2002Report-Final-Updated.pdf

Prins, J. (1959). Some notes about Islam and politics in Indonesia. Die Welt des Islams, $6(1 / 2), 117-129$. 
Priyambodo, R. (2006, 22 August). Muhammadiyah kecam Israel tolak pasukan perdamaian Indonesia (Muhammadiyah condemn Israel's rejection on Indonesian peacekeeping force). AntaraNews.com. Retrieved from http://www.antaranews.com/berita/40509/muhammadiyah-kecam-israel-tolakpasukan-perdamaian-indonesia

PTRI. (2008, 18 February). Security Council (2006-2008). Indonesia's Permanent Mission to the United Nations (PTRI)-New York. Retrieved from http://www.indonesiamission-ny.org/NewStatements/ps021808.htm

Puji, S. T. (2011, 10 August). Kosovo minta Indonesia akui kemerdekaannya (Kosovo requests Indonesia to recognize its independence) Republika Online. Retrieved from http://www.republika.co.id/berita/internasional/global/11/08/10/lppgj5kosovo-minta-indonesia-akui-kemerdekaannya

Purba, K. (2005, 21 September). Even Palestine approves of our contact with Israel. The Jakarta Post. Retrieved from https://global.factiva.com/ha/default.aspx\#./!?\&_suid=14328900359060812408896 $\underline{3463488}$

Purwadi, D. (2012, 26 February). Indonesia galang dukungan untuk Palestina (Indonesia sought support for Palestine). Republika Online. Retrieved from http://www.republika.co.id/berita/nasional/umum/12/02/26/lzzwvs-indonesiagalang-dukungan-untuk-palestina

Putnam, R. D. (1988). Diplomacy and domestic politics: The logic of two-level games. International Organization, 42(3), 427-460.

Putnam, R. D., \& Campbell, D. E. (2010). American grace: How religion divides and unites us. New York: Simon and Schuster.

Qodari, M. (2001, 7 March). Islamic student groups must be alert. The Jakarta Post. Retrieved from http://www.thejakartapost.com/news/2001/03/07/islamic-studentgroups-must-be-alert.html

Raillon, F. (1993). The new order and Islam, or the imbroglio of faith and politics. Indonesia(57), 197-217. Retrieved from http://www.jstor.org/stable/3351248

Rajagukguk, H. R. A. (2009). Sikap kritis parlemen terhadap kebijakan luar negeri Indonesia dalam kasus resolusi DK PBB tentang isu nuklir Iran (Critical stance of the parliament on Indonesia's foreign policy: The case of the UNSC resolution on the Iranian nuclear issue). (MA Masteral thesis), University of Indonesia, Jakarta. Retrieved from http://lontar.ui.ac.id/opac/themes/libri2/detail.jsp?id=128955\&lokasi=lokal

Rakhmawati, N. (2010). Dialog dam diplomasi di Indonesia (Dialogue and diplomacy in Indonesia). In J. B. B. Z. A. Bagir (Ed.), Dialog antar umat beragama: Gagasan dan praktik di Indonesia (Interfaith dialogue: Ideas and practice in Indonesia) (pp. 97-130). Bandung: Mizan Publika.

Ramadhan, S. (2012, 16 December). Parlemen Indonesia dan Palestina telah jalin hubungan bilateral (Parliaments of Indonesia and Palestine established bilateral relations). Suara-Islam.com. Retrieved from http://www.suaraislam.com/read/index/6105/Parlemen-Indonesia-dan-Palestina-Telah-JalinHubungan-Bilateral

Ramage, D. E. (1995). Politics in Indonesia: Democracy, Islam and the ideology of tolerance. London: Routledge.

Ratya, M. P. (2012, 19 November). SBY sebaiknya temui Obama di KTT ASEAN untuk bicara soal Palestina (SBY should better meet Obama in ASEAN Summit to discuss Palestine's issue). DetikNews Retrieved from 
http://finance.detik.com/read/2012/11/19/062908/2093850/10/sby-sebaiknyatemui-obama-di-ktt-asean-untuk-bicara-soal-palestina

Reid, A. (1967). Nineteenth century pan-Islam in Indonesia and Malaysia. The Journal of Asian Studies, $26(2$ (February)), 267-283.

Republika. (1994, 10 November). Alatas sesalkan kunjungan ke Israel (Alatas regrets the visit to Israel). Republika. Retrieved from http://www.library.ohiou.edu/indopubs/1994/11/12/0013.html

RIB. (2014, 09 October). Dompet Dhuafa bangun 10 sekolah di Gaza (Dhompet Dhuafa builds 10 schools in Gaza). IRIB Indonesia. Retrieved from http://indonesian.irib.ir/international/timur-tengah/item/86325-dompet-dhuafabangun-10-sekolah-di-gaza

Ribuffo, L. (1998). Religion and American foreign policy. National Interest, 52, 36-49.

Ricklefs, M. C. (2008). A history of modern Indonesia since c. 1200 (Fourth ed.). California: Stanford University Press.

Ricklefs, M. C. (2012). Mengislamkan Jawa: Sejarah Islamisasi dan penentangnya dari 1930 sampai sekarang (Islamisation and Its opponents in Java). Jakarta: Serambi Ilmu Semesta.

Riddell, P. G. (2002). The diverse voices of political Islam in Post-Suharto Indonesia. Islam and Christian-Muslim Relations, 13(1), 65-84. doi:10.1080/09596410210299

Rieken, J. (2014). The Gaza-Israel crisis: What comes next? Palestine - Israel Journal of Politics, Economics, and Culture, 19/20(4/1), 124-139. Retrieved from http://search.proquest.com/docview/1628560838?accountid=14782

Ripsman, N. M., Taliaferro, J. W., \& Lobell, S. E. (2009). Conclusion: The state of neoclassical realism. In S. E. Lobell, N. M. Ripsman, \& J. W. Taliaferro (Eds.), Neoclassical realism, the state, and foreign policy (pp. 280-299). Cambridge: Cambridge University Press.

Robani, A. (2010). The attitude and commitment of the Malaysian government towards Islam in foreign policy (1957-2003): An assessment. Proceeding Seminar on National Resilience (SNAR 2010) "Political Management and Policies" in Malaysia, 13-15 July 2010.

Rubenberg, C. A. (2003). The Palestenians: In search of a just peace. Boulder: Lynne Rienner.

Rusla. (2007, 18 April). Anggota DPR tolak kedatangan Israel di IPU Bali (MPs denied the coming of Israel to IPU-Bali). AntaraNews.com. Retrieved from http://www.antaranews.com/berita/59557/anggota-dpr-tolak-kedatangan-israel-diipu-bali

Sabri, M. (2012). Presiden Tersandera: Melihat dampak sistem presidensial-multipartai terhadap relasi presiden-DPR di masa pemerintahan SBY-Budiono (The hostaged presiden: Observing presidential-multy party system towards the president and the parliament relations in the SBY-Budiono administration). Jakarta: RMBooks.

Said, E. W. (2000). The end of the peace process: Oslo and after. London: Granta Books.

Saikal, A. (2006). The Iran nuclear dispute. Australian Journal of International Affairs, 60(2), 193-199. doi:10.1080/10357710600696118

Samson, A. A. (1968). Islam in Indonesian politics. Asian Survey, 8(12), 1001-1017. Retrieved from http://www.jstor.org/stable/2642153

Samson, A. A. (1971). Army and Islam in Indonesia. Pacific Affairs, 44(4), 545-565. Retrieved from http://www.jstor.org/stable/2756611

Saravanamutu, J. (2010). Malaysia's foreign policy: The first fifty years: Alignment, neutralism, Islamism. Singapore: Institute of Southeast Asian Studies. 
Sasongko, A. (2013, 13 May). Muhammadiyah ingin kemerdekaan Kosovo diakui (Muhammadiyah wants Kosovo's independence to be recognized). Republika Online. Retrieved from http://www.republika.co.id/berita/dunia-islam/islammancanegara/13/05/13/mmqgc9-muhammadiyah-ingin-kemerdekaan-kosovodiakui

Sasongko, A. (2014, 14 July). PBNU buka rekening bantuan untuk Gaza (PBNU open an account for helping Gaza). Republika Online. Retrieved from http://www.republika.co.id/berita/internasional/palestina-israel/14/07/14/n8pfekpbnu-buka-rekening-bantuan-untuk-gaza

Schake, K. (2007). Dealing with a nuclear Iran. Policy Review. April/May 2007. Retrieved from http://www.hoover.org/research/dealing-nuclear-iran

Schwartz, S. (2002). The Arab betrayal of Balkan Islam. The Middle East Quaterly, 9(2), 43-52. Retrieved from http://www.meforum.org/166/the-arab-betrayal-of-balkanislam

Schwarz, A. (2012). A nation in waiting: Indonesia's search for stability. Singapore: Talisman.

Shaffer, B. (2002). Is there a Muslim foreign policy? The case of Caspian. Current History, 101( 658), 382-387.

Shaffer, B. (2006a). Introduction: The limits of culture. In B. Shaffer (Ed.), The limits of culture: Islam and foreign policy (pp. 1-26). Cambridge, Massahusetts: The MIT Press.

Shaffer, B. (2006b). The Islamic republic of Iran: It is really? In B. Shaffer (Ed.), The limits of culture: Islam and foreign policy (pp. 219-240). Cambridge, Massachusetts: The MIT Press.

Shaleh, M. H. (2007, 31 March). DPD Sesalkan Dukungan RI pada Resolusi DK PBB (DPD regrets RI's supports on UNSC resolution). Suara Merdeka CyberNews. Retrieved from http://www.suaramerdeka.com/cybernews/harian/0703/31/nas2.htm Shankland, D. (2007). Islam and politics in Turkey: The 2007 presidential elections and beyond. International Affairs, 83(2), 357-371.

Sherrill, C. W. (2012). Why Iran wants the bomb and what it means for US policy. The Nonproliferation Review, 19(1), 31-49. Retrieved from http://dx.doi.org/10.1080/10736700.2012.655084

Sherrill, C. W. (2014). Why Hassan Rouhani won Iran's 2013 presidential elections. Middle East Policy, XXI(2), 64-75. Retrieved from http://onlinelibrary.wiley.com/doi/10.1111/mepo.12071/pdf

Sihbudi, R. (1997). Indonesia dan Timur Tengah: Masalah dan prospek (Indonesia and Middle-East: Problems and prospects). Jakarta: Gema Insani Press.

Sihbudi, R. (2001a). Politik luar negeri Indonesia terhadap Bosnia, Kosovo, dan Chechnya (Indonesian foreign policy towards Bosnia, Kosovo and Chechnya). In M. H. Basyar (Ed.), Indonesia dan problematika Muslim di Bosnia, Kosovo, dan Chechnya (Indonesia and the problem of Muslims in Bosnia, Kosovo and Chechnya) (pp. 125-152). Jakarta: Indonesian Institute of Sciences.

Sihbudi, R. (2001b, 22 Februari). What Middle East means to RI. The Jakarta Post. Retrieved from https://global.factiva.com/ha/default.aspx\#./!?\&_suid=14325209239860305166892 40685263

Sihbudi, R. (2007a). Menyandera Timur Tengah: Kebijakan AS dan Israel atas negaranegara Muslim (Hostaged the Middle-East: the US and Israel's policy towards Muslim countries). Jakarta: Mizan. 
Sihbudi, R. (2007b, 29 March). Muhammadiyah, NU, dan Iran (Muhammadiyah, NU and Iran). Republika. Retrieved from http://qitori.wordpress.com/2007/04/03/muhammadiyah-nu-dan-iran/

Sijabat, R. M. (2007, 16 May). House to question government over UN sanctions on Iran The Jakarta Post. Retrieved from http://www.thejakartapost.com/news/2007/05/16/house-question-government-overun-sanctions-iran.html

Silk, M. (2012). American exceptionalism and political religion in Republican politics today. The Review of Faith \& International Affairs, 10(2), 33-40. Retrieved from http://dx.doi.org/10.1080/15570274.2012.682516

Skidmore, D., \& Hudson, V. M. (1993). Establishing the limits of state autonomy: Contending approaches to the study of state-society relations and foreign policy making. In D. Skidmore \& V. M. Hudson (Eds.), The limits of state autonomy: Societal groups and foreign policy formulation. Colorado, USA: Westview Press.

Smidt, C. E. (2005). Religion and American attitudes toward Islam and an invasion of Iraq. Sociology of Religion., 66(3), 243-261.

Smith, A. (2000). Indonesia's foreign policy under Abdurrahman Wahid: Radical or status quo state? Contemporary Southeast Asia, 22(3), 498-526. Retrieved from http://www.jstor.org/stable/25798509

Smith, A. (2003). A glass half full: Indonesia-U.S. relations in the age of terror. Contemporary Southeast Asia, 25(3), 449-472. Retrieved from http://www.jstor.org/stable/25798657

Smith, A. ( 2010). Reluctant partner: Indonesia's response to U.S. security policies. Asian Affairs: An American Review, 30(2), 142-150. Retrieved from ADA592297

Smith, B. (2011). Iran's nuclear programme: an update. Retrieved from

Solomon, J. (1999, 1999 Nov 12). Indonesia seeks official ties with Israel: Aim Is to boost economy, improve relations between Jews, Muslims. Asian Wall Street Journal, p. 5. Retrieved from http://search.proquest.com/docview/315485684?accountid=14782

Somekh, B., \& Lewin, C. (Eds.). (2005). Research methods in the social science. London SAGE Publications.

Spies, M. (2009, Oct-Dec 2009). Solving the Iran nuclear situation peaceably: An update on the dual track approach. Peace Magazine, 25, 11-14.

Stan, L., \& Turcescu, L. (2005). Pulpits, ballots and party cards: Religion and elections in Romania. Religion, State and Society, 33(4), 347-366. Retrieved from http://dx.doi.org/10.1080/09637490500350827

Starr, J. (2010). The UN resolutions. In R. B. Wright (Ed.), The Iran primer: Power, politics, and U.S. policy (pp. 119-122). Washington DC: United States Intitute of Peace.

Steans, J., \& Pettiford, L. (2001). International relations: Perspectives and themes. England: Pearson Education Limited.

Suara-Merdeka. (2007a, 27 March). Din sesalkan sikap RI dukung resolusi PBB (Din regrets RI's support on UN resolution). Suara Merdeka CyberNews. Retrieved from http://www.suaramerdeka.com/cybernews/harian/0703/27/nas19.htm

Suara-Merdeka. (2007b, 27 March). DPR diminta ajukan interpelasi: Sikap RI soal nuklir Iran ((The House was asked to put forward the legislature' interpellation right with regard to RI's position on the Iranian Nuclear). Suara Merdeka. Retrieved from http://www.suaramerdeka.com/harian/0703/27/nas05.htm 
Sukma, R. (1997). Indonesia's bebas-aktif foreign policy and the 'security agreement' with Australia. Australian Journal of International Affairs, 51(2), 231-241. Retrieved from http://dx.doi.org/10.1080/10357719708445212

Sukma, R. (2003). Islam in Indonesian foreign policy. London, UK: Routledge

Sukma, R. (2008). Indonesia's foreign policy since reformasi: Change and continuity. Southeast Asia Bulletin(June), 1-5.

Sukma, R. (2010). Indonesia's 2009 elections: Defective system, resilient democracy. In E. Aspinal \& M. Mietzner (Eds.), Problems of democratization in Indonesia: Elections, institutions and society. Singapore: ISEAS.

Sukma, R. (2011). Soft power and public diplomacy: The case of Indonesia. In S. J. Lee \& J. Melissen (Eds.), Public diplomacy and soft power in East Asia (pp. 91-115). New York: Palgrave Macmillan.

Sukma, R. (2012). Domestic politics and international posture: Constraints and possibilities. In A. Reid (Ed.), Indonesia rising: The repositioning of Asia's third giant (pp. 77-92). Singapore: ISEAS.

Sukma, R., \& Joewono, C. (Eds.). (2007). Islamic thought and movements in contemporary Indonesia. Jakarta: Center for Strategic and International Studies (CSIS).

Sumanto, M. (2012). Sejarah peradaban Islam Indonesia (The History of Islamic civilization in Indonesia) (Fourth ed.). Jakarta: Rajawali Pers.

Suryadinata, L. (1995). Islam and Suharto's foreign policy: Indonesia, the Middle East, and Bosnia. Asian Survey, 35(3), 291-303. Retrieved from http://www.jstor.org/stable/2645546

Suryadinata, L. (1996). Indonesia's foreign policy under Suharto: Aspiring to international leadership. Singapore: Times Academic Press.

Suryaningtyas, T. (2007, 2 April). Tersedak dalam Jebakan Resolusi PBB (Choked in the trap of UN resolution). Kompas. Retrieved from http://kompas.com/kompascetak/0704/02/Politikhukum/3424567.htm

Susser, A. (2014). Israel's place in a changing regional order (1948-2013). Israel Studies, 19(2), 218-238.

Suwarjono, \& Nugraheni, M. (2009, 2 January). Ribuan anggota PKS demo menentang Israel (Thousands of PKS supporters held demonstrations protesting Israel). Viva.co.id. Retrieved from http://nasional.news.viva.co.id/news/read/19150ribuan_anggota_pks_demo_menentang_israel

Swatos, W. H. (1989). Religious politics in global and comparative perspective. New York: Greenword Press.

Syamsuddin, M. S. (1991). Religion and politics in Islam: The case of Muhammadiyah in Indonesia's new order. (PhD), UCLA.

Takeyh, R. (2006). Hidden Iran: Paradox and power in the Islamic republic. New York: Time Books, Henry Holt and Company.

Taliaferro, J. W., Lobell, S. E., \& Ripsman, N. M. (2009). Introduction: Neoclassical realism, the state, and foreign policy. In S. E. Lobell, N. M. Ripsman, \& J. W. Taliaferro (Eds.), Neoclassical realism, the state, and foreign policy (pp. 1-41). Cambridge: Cambridge University Press.

Tanuwijaya, S. (2010). Political Islam and Islamic parties in Indonesia: Critically assessing the evidence of Islam's political decline. Contemporary Southeast Asia, 32(1 (April)), 29-49.

Taspinar, O. ( 2011). The rise of Turkish Gaullism: Geeting Turkish-American relations right Insight Turkey, 13(1), 11-17. 
Telegraph. (2006, 04 /07). Send jihad to Israel: Bashir. The Daily Telegraph, p. 2. Retrieved from http://search.proquest.com/docview/359472910?pqorigsite $=$ summon $\&$ accountid $=14782 \#$

Tempo. (2007, 23 April). Presiden terima proposal penyelesaian Kosovo (President receives proposal on Kosovo's settlement). Tempo Interaktif. Retrieved from http://tempo.co.id/hg/nasional/2007/04/23/brk,20070423-98594,id.html

Terhallea, M. (2015). Why revolutionary states yield: International sanctions, regime survival and the security dilemma. The case of the Islamic Republic of Iran. International Politics (2015) 52, 594-608, 52, 594-608. Retrieved from http://www.palgrave-journals.com/ip/journal/v52/n5/pdf/ip201531a.pdf

The-Economist. (2011, 25 February). Libya's Balkan connections: Qaddafi's Yugoslav friends The Economist. Retrieved from http://www.economist.com/blogs/easternapproaches/2011/02/libyas_balkan_conne $\underline{\text { ctions }}$

Thomas, S. M. (2005). The global resurgence of religion and the transformation of international relations : The struggle for the soul of the Twenty-first Century New York: Palgrave Macmillan.

Tirtosudarmo, R. (1992a). Indonesia 1991: Quest for democracy in a turbulent year. Southeast Asian Affairs, 19(0), 123-139.

Tirtosudarmo, R. (1992b). Indonesia 1991: Quest for democracy in a turbulent year. Southeast Asian Affairs, 123-139.

TodaysZaman. (2008, 11 March). Turkey lobbying for stronger Muslim support for Kosovo Todays Zaman. Retrieved from http://www.todayszaman.com/diplomacy_turkey-lobbying-for-stronger-muslimsupport-for-kosovo_136077.html

TodaysZaman. (2013, 2 May). OIC secretary-general visits Kosovo for first time Todays Zaman. Retrieved from http://www.todayszaman.com/latest-news_oic-secretarygeneral-visits-kosovo-for-first-time $314252 . \mathrm{html}$

Tombeg, L. (2014, 11 July ). Pemerintah RI bantu Rp 1 juta dolar ke Palestina (Indonesian government assisted US\$ 1 million to Palestine). Tribun Manado.

Toprak, M., Uslu, N., \& Yilmaz, M. (2011). Public perceptions of radical Islam: Democratic consolidation vs secular fundamentalism. Journal of Third World Studies, 28(1), 203-229. Retrieved from http://search.proquest.com/docview/884214851?accountid=14782

Travers, M. ( 2001). Qualitative research through case studies London: SAGE Publications.

Tribunnews. (2013, 19 June). Tantowi minta maaf terkait kunjungan ke Israel (Tantowi apologized with regard to his visit to Israel). Tribun Nasional. Retrieved from http://www.tribunnews.com/nasional/2013/06/19/tantowi-minta-maaf-terkaitkunjungan-ke-israel

Triyudha, A. (2011, 9 August ). MUI usul RI akui Kosovo (MUI suggests RI to recognize Kosovo). Jurnas.com. . Retrieved from http://www.jurnas.com/news/36814/MUI_Usul_RI_Akui_Kosovo_2011/1/Internas ional/Asia

UNGA. (2012). Resolution adopted by the General Assembly on 29 November 2012. Retrieved from http://www.un.org/en/ga/search/view doc.asp?symbol=A/RES/67/19

UNSC. (2006). Resolution 1696 (2006): Adopted by the Security Council at its 5500th meeting, on 31 July 2006. Retrieved from New York: https://www.iaea.org/sites/default/files/unsc_res1696-2006.pdf 
UNSC. (2007a). Report of the Security Council mission on the Kosovo issue. Retrieved from New York: http://www.securitycouncilreport.org/atf/cf/\%7B65BFCF9B6D27-4E9C-8CD3-CF6E4FF96FF9\%7D/kos\%20S2007\%20256.pdf

UNSC. (2007b). Resolution 1747 (2007): Adopted by the Security Council at its 5647th meeting on 24 March 2007. Retrieved from New York: https://www.iaea.org/sites/default/files/unsc_res1747-2007.pdf

UNSC. (2008a). Kosovo situation calm, but political transition following declaration of independence more complex than expected, security council told [Press release]. Retrieved from http://www.un.org/press/en/2008/sc9512.doc.htm

UNSC. (2008b). Resolution 1803 (2008): Adopted by the Security Council at its 5848th meeting on 3 March 2008. Retrieved from New York: https://www.iaea.org/sites/default/files/unsc res1803-2008.pdf

UNSC. (2008c). Resolution 1835 (2008): Adopted by the Security Council at its 5984th meeting on 27 September 2008. Retrieved from New York: https://www.iaea.org/sites/default/files/unsc_res1835-2008.pdf

UNSC. (2008d). Security Council reaffirms earlier resolutions on Iran's uranium enrichment, calls on country to comply with obligations "fully and without delay' [Press release]. Retrieved from http://www.un.org/press/en/2008/sc9459.doc.htm

Vandebosch, A. (1952). Nationalism and religion in Indonesia Far Eastern Survey, 21(18 (17 December)), 181-128.

Vatikiotis, M. R. J. (1998). Indonesian politics under Suharto: The rise and fall of the new order (Third ed.). London: Routledge.

Vermonte, P. J. (2005). Demokratisasi dan politik luar negeri Indonesia: Membangun citra diri (Democratization and Indonesia's foreign policy: Building self image). In B. Bandoro (Ed.), Mencari Desain Baru Politik Luar Negeri Indonesia (Searching a new design of Indonesia's foreign policy) (pp. 27-40). Jakarta: Centre for Strategic and International Studies.

Vermonte, P. J. (2014). Foreign policy begins at home: The democratic source of Indonesia's foreign policy under SBY's presidency (2004-2014). The Indonesian Quarterly, 42(3-4), 201-215.

Vidmar, J. (2009). International legal responses to Kosovo's declaration of independence. Vanderbilt Journal of Transnational Law, 42, 779-851.

Vinocur, J., \& Richardson, M. (1999, 14 April). Only Indonesia and China find reasons to bbject : For Asians, battle for Kosovo is distant. The New York Times Retrieved from http://www.nytimes.com/1999/04/14/news/14iht-react.2.t.html

Visoka, G., \& Bolton, G. (2011). The complex nature and implications of international engagement after Kosovo's independence. Civil Wars, 13(2), 189-214. Retrieved from http://dx.doi.org/10.1080/13698249.2011.576158

Vlekke, B. H. M. (1959). Indonesia's struggle 1957-1958. Retrieved from The Hague:

Wahid, A. (1996). Foreword. In G. Barton \& G. Fealy (Eds.), Nahdlatul Ulama, traditional Islam modernity in Indonesia. Clayton, Australia: Monash Asia Institute

Wald, K. D., \& Brown, A. C. (2011). Religion and politics in the US. Maryland: The Rowman and Littlefield Publishing.

Wallace, W. (1971). Foreign policy and the political process. London: Macmillan.

Wallis, J. (2004). Dangerous Religion: George W. Bush's Theology of Empire. Mississippi Review, 32(3), 60-72.

Walter, M. (2010). The nature of social science research. In M. Walter (Ed.), Social research methods (Second ed.). Melbourne, Australia: Oxford University Press. 
Warbrick, C. (2008). I. Kosovo: The declaration of independence. International \& Comparative Law Quarterly, 57(03), 675-690. Retrieved from http://dx.doi.org/10.1017/S002058930800047X

Warner, C. M., \& Walker, S. G. (2011). Thinking about the role of religion in foreign policy: A framework for analysis. Foreign Policy Analysis, 7(1), 113-135. Retrieved from http://dx.doi.org/10.1111/j.1743-8594.2010.00125.x

Warning, M., \& Kardas, T. (2011). The impact of changing Islamic identity on Turkey's new foreign policy. Alternative Turkish Journal of International Relations, 10(2-3 Summer-Fall).

Waskita, F. (2013, 12 June). Golkar tidak tahu kuunjungan Tantowi ke Israel (Golkar doesn't know Tantowi's visit to Israel. Tribun Nasional.

Waxman, D. (2011). Israel's Palestinian minority in the two-state solution: The missing dimension. Middle East Policy, 18(4), 68-82. Retrieved from http://search.proquest.com/docview/914990988?accountid=14782

Weatherbee, D. E. (1984). Indonesian in 1984: Pancasila, politics, and power. Asian Survey, 25(2), 187-197.

Webber, M., \& Smith, M. ( 2002). Foreign Policy in a transformed world. Harlow, England Prentice Hall.

Weck, W., Hassan, N., \& Abubakar, I. (Eds.). (2011). Islam in the public sphere: The politics of identity and the future of democracy in Indonesia. Jakarta: Center for the Study of Religion and Culture (CSRC).

Weinstein, F. B. (1971). The Indonesian elite's view of the world and the foreign policy of development. Indonesia(12), 97-131. Retrieved from http://www.jstor.org/stable/3350661

Weinstein, F. B. (1976). Indonesian foreign policy and the dilemma of dependence. Ithaca, New York: Cornel University Press.

Weiss, M. L. (2010). Southeast Asia's Muslim majority democracies elections and Islamism outside the MENA region. Taiwan Journal of Democracy, 6(1), 81 - 106.

Weller, M. (2008). Kosovo's final status. International Affairs, 84(6), 1223-1243. Retrieved from http://dx.doi.org/10.1111/j.1468-2346.2008.00766.x

Wicaksana, I. G. W. (2012). Islam and Indonesia's foreign policy, with special focus on Jakarta-Islamabad relations. (PhD), The University of Western Australia.

Widjaya, I., \& Huda, E. (2009, 9 January). Pemuda Muhammadiyah desak usir Dubes Amerika (Muhammadiyah youth urged to deport the US ambassador). Viva.co.id. Retrieved from http://nasional.news.viva.co.id/news/read/20777pemuda_muhammadiyah_usir_dubes_amerika

Wijaksana, D. (2006, 4 May). Yudhoyono meeting with Abbas in Jordan canceled: Hassan The Jakarta Post. from http://www.thejakartapost.com/news/2006/05/04/yudhoyono-meeting-abbasjordan-canceled-hassan.html

Wilcox, C. (1990). Religion and politics among white evangelicals: The impact of religious variables on political attitudes. Review of Religious Research, 32(1), 2742. Retrieved from http://www.jstor.org/stable/3511325

Willis, J. W., Jost, M., \& Nilakanta, R. (2007). Foundations of qualitative research: Interpretive and critical approaches. London: SAGE Publications.

Wirajuda, N. H. (2007). Penjelasan menteri luar negeri dalam rapat kerja dengan Komisi I DPR RI mengenai resolusi DK PBB no. 1747 tentang masalah nuklir Iran (The explanation of minister for foreign affairs at a meeting with the Commission I's House of Representatives-RoI concerning UNSC resolution no. 1747 Iran's nuclear 
issu). Departemen Luar Negeri (Department of Foreign Affairs), Republic of Indonesia). Jakarta.

Wismabrata. (2012, 20 November ). Ratusan siswa di Solo berdoa untuk Palestina (Hundreds of students in Solo prayed for Palestine). Kompas.com. Retrieved from http://regional.kompas.com/read/2012/11/20/21205391/Ratusan.Siswa.di.Solo.Ber doa.untuk.Palestina

Witular, R. A. (2006, 1 February). RI fears Iran nuclear crisis will strike economy The Jakarta Post. Retrieved from http://www.thejakartapost.com/news/2006/02/01/rifears-iran-nuclear-crisis-will-strike-economy.html

Wolff, S., \& Rodt, A. P. (2013). Self-determination after Kosovo. Europe-Asia Studies, 65(5), 799-822. doi:10.1080/09668136.2013.792450

Wuthnow, R., \& Lewis, V. ( 2008). Religion and altruistic US foreign policy goals: Evidence from a national survey members. Journal for the Scientific Study of Religion, 47 (2), 191-209.

Xinhua. (2005, 7 September). Indonesia not to form ties with Israel before Palestine's freedom. Xinhua News Agency. Retrieved from http://search.proquest.com.helicon.vuw.ac.nz/docview/452687469?pqorigsite $=$ summon\&accountid $=14782$

Xinhua. (2006a, 27 January). Indonesia favours diplomatic settlement of Iranian nuclear issue. Xinhua News Agency. Retrieved from http://ic.galegroup.com/ic/whic/NewsDetailsPage

Xinhua. (2006b, 1 February). Indonesia asks Iran to comply with Russia's offer Xinhua News Agency Retrieved from http://go.galegroup.com/ps/retrieve.do?sort

Xinhua. (2006c, 20 March). Indonesia plans to open mission in Palestine. Xinhua News Agency. Retrieved from http://search.proquest.com/docview/452579889?pqorigsite $=$ summon\&accountid $=14782$

Xinhua. (2006d, 3 July). Indonesia says little chance to open ties with Israel Xinhua News Agency. Retrieved from http://search.proquest.com/docview/452494991?pqorigsite $=$ summon $\&$ accountid $=14782$

Xinhua. (2007a, 27 January). Indonesia, South Africa Ask for Seeking Dialogue on Iran Nuclear Dispute. Xinhua News Agency. Retrieved from http://en.people.cn/200703/23/eng20070323_360423.html

Xinhua. (2007b, 31 March). Indonesia refuses attempt to resort to military in settling Iranian nuclear problem Xinhua News Agency. Retrieved from http://news.xinhuanet.com/english/2007-03/31/content 5918986.htm

Yegar, M. (2006). The Republic of Indonesia and Israel. Israel Affairs, 12(1), 136-158. Retrieved from http://dx.doi.org/10.1080/13537120500382016

Yin, R. K. (2003). Case study research: Design and methods. (Third ed.). London: SAGE Publications.

Yu, X. (2012, 17 January). RI: Difficult to open mission in Palestine Retrieved from http://www.thejakartapost.com/news/2012/01/17/ri-difficult-open-missionpalestine $0 . h t m l$

Yudhoyono, S. B. (2005). Speech by President of the Republic of Indonesia before the Indonesian Council on World Affairs (ICWA), Jakarta, May 19. Retrieved from http://www.presidenri.go.id/index.php/pidato/2005/05/19/332.html

Yudhoyono, S. B. (2006, 10 February). Let s try to get beyond caricatures. International Herald Tribune from http://www.nytimes.com/2006/02/10/opinion/10iht-edsby.html? r $=0$

Yunanto, R. (2008, 30 December). Diserbu' massa anti Israel, pengamanan Kedubes AS diperketat (Flooded with anti-Israeli mass, the security of the US embassy 
tightened.

DetikNews.

Retrieved

from

http://finance.detik.com/read/2008/12/30/133539/1060820/10/diserbu-massa-anti-

israel-pengamanan-kedubes-as-diperketat

Yusanto, M. I. (2007, 28 March ). Resolusi DK PBB terhadap program nuklir Iran: Pernyataan Hizbut Tahrir Indonesia (UNSC resolution on Iran's nuclear programme: Statement of Hizbut Tahrir Indonesia). Hizbut Tahrir Indonesia. Retrieved from http://www.hizbut-tahrir.or.id/2007/03/29/resolusi-dk-pbbterhadap-program-nuklir-iran/

Zarif, M. J. (2014). What Iran really wants. Foreign Affairs, 93(3), 49-59. Retrieved from http://helicon.vuw.ac.nz/login?url=http://search.ebscohost.com/login.aspx?direct=tr $\underline{\text { ue } \& \mathrm{db}=\mathrm{a} 2 \mathrm{~h} \& \mathrm{AN}=95603429 \& \text { site }=\text { ehost-live }}$

Zubaidah, N. (2014, 10 February). NU menentang regulasi pembatasan tembakau (NU opposes regulation on limiting tobacco). SindoNews.com. Retrieved from http://nasional.sindonews.com/read/834278/15/nu-menentang-regulasipembatasan-tembakau-1391995844 


\section{APPENDIX}

\section{INTERVIEWEES}

1. A Malik Haramain (25 November 2013) : MP, PKB (National Awakening Party)

2. Abdul Azis (18 November 2013) : Deputy Director of Public Diplomacy, MFA

3. Abdul Mutaali, Dr. (9 December 2013) : Director, Canter for Islam and MiddleEast University of Indonesia

4. Abdillah Toha (11 December 2013) : Former MP, National Mandate Party (PAN)

5. Abdur Rochman (30 September 2013) : Politician, National Awakening Party (PKB)

6. Abdul Mu'ti, Dr. (16 October 2013) : Secretary General, Central Executive Board of Muhammadiyah

7. Adnan Anwar (3 October 2013) : Secretary, Central Executive Board of NU (PBNU)

8. Ahmad Suady (11 September 2013) : Director, Wahid Canter

9. Ali Munhanif, Dr. (12 September 2013) : Director, Centre of Islam and Society Studies (PPIM), State Islamic University (UIN), Jakarta

10. Al Muzammil Yusuf (26 september 2013) : MP, PKS (Prosperous Justice Party)

11. Andy Rachmianto, Mphil. (25 september 2013) : Director, International Security and Disarmament, MFA.

12. Anak Agung Banyu Perwita, Prof., Dr. (31 October 2013) : President University

13. Arko Hananto Budiardi (9 September 2013) : Dir. Social and Cultural Affairs and International and Organizations of Developing Countries, MFA

14. Asrori S. Karni (21 September 2013) : Journalist, GATRA

15. As'ad Said Ali (10 December 2013) : Vice Chairman of NU

16. Azyumardi Azra, Prof., Dr. (25 October 2013) : Director, Graduate School of State Islamic University (UIN), Jakarta

17. Badrul Munir (4 september 2013) : National Awakening Party (PKB)

18. Bahtiar Effendy, Prof., Dr. (4 October 2013) : Dean, Faculty of Politics and Social Science, UIN

19. Ben Perkasa Drajat, Dr. (23 September 2013) : Director, junior Diplomatic School, MFA

20. Budi R. Suryasaputra (20 September 2013) : Staff, MFA and former staff at the Indonesian Embassy in Tehran

21. Dewi Fortuna Anwar, Praf., Dr. (20 November 2013) : Professor Research, Indonesian Institute of Sciences (LIPI)

22. Dhuroruddin Masad (16 December 2013) : Senior researcher, LIPI

23. Febrian Ruddyard (19 September 2013) : Director for Middle Eastern Affairs, MFA 
24. Ferry Nur (2 November 2013) : Chairman, Committee of Indonesian Solidarity for Palestine

25. Hidayat Nur Wahid, Dr. (2 December 2013) : MP, PKS

26. Hasyim Muzadi, KH (29 December 2013) : Former chairman of NU

27. Iis Gindarsyah (14 October 2013) : Researcher, CSIS

28. Ilham Khoiri (30 October 2013) : Journalist, KOMPAS

29. Ismail Yusanto (9 December 2013) : Spokesperson, HTI

30. Jalaluddin Rachmat, Dr. (6 December 2013) : Chairman, Advisory Board of IJABI (Shiite sect)

31. Jose Rizal, Dr. (3 Nopember 2012) : President, MERC

32. Jusuf Kalla (4 December 2013) : Indonesian Vice President in the periods of 20042009 and 2014-2019

33. Luluk Nur Hamidah, MSc., MPA (2 December 2013) : Politician, PKB (National Awakening Party)

34. Mahfudz Siddiq (25 November 2013) : MP, PKS

35. Maskuri Abdillah, Prof., Dr. (30 September 2013) : Secretary, Presidential Advisory Board and former PBNU

36. M. Ibrahim Hamdani (14 November 2013) : Assistant Director, Canter for Middle East and Islam, University of Indonesia

37. Muhammad Rommaharmuzi (27 November 2013) : MP, United Development Party (PPP)

38. Muhyidin Junaidi, KH. (5 October 2013) : Chairman, Indonesian Council of Ulama (MUI)

39. M Najib, (17 October 2013) : MP, PAN

40. N. Hassan Wirajuda, Dr. (18 December 2013) : Former Indonesian foreign Minister

41. Novi Dwi Ratnasari (10 Januari 2014) : An official, MFA

42. Pribadi Sutiono, Dr. (9 October 2013) : Former Director of Senior Diplomatic School, MFA

43. R Ferdian Andi R (19 Nopember 2013) : Journalist, inilah.com.

44. Riefqi Muna, Dr. (2 December 2013) : Senior researcher, LIPI

45. Rizal Sukma, Dr. (19 January 2014) : Executive Director, CSIS

46. Said Agil Siraj, KH., Dr. (11 November 2013) : General Chairman, PBNU

47. Saleh P. Daulay, Dr. (10 october 2013) : MP, PAN

48. Santo Darmosumarto, Dr. (31 December 2013) : President Special Office for International Relations

49. Sukron Kamil, Prof., Dr. (28 August 2013) : Professor, UIN Jakarta

50. TB. Ace Hasan Syadzily (7 November 2013) : MP, Golkar Party

51. Tolhah Ubaidi (9 October 2013) : Official, MFA

52. Umar Hadi (25 September 2013) : Director for European Affairs and former Director for Public Diplomacy, MFA

53. Yayan G. Mulyana, Dr. (18 January 2014) : President Special Office for International Relations 